UNIVERSIDADE DE SÃO PAULO

PEDRO JULIANO DELAROLE

O Conservatório Dramático e Musical "Dr. Carlos de Campos" de Tatuí como difusor cultural

São Paulo 
PEDRO JULIANO DELAROLE

\section{O Conservatório Dramático e Musical "Dr. Carlos de Campos" de Tatuí como difusor cultural}

Dissertação apresentada ao Programa de PósGraduação em Música, área de concentração Musicologia, linha de pesquisa História, Estrutura e Estilo na Música, da Escola de Comunicações e Artes da Universidade de São Paulo, como exigência parcial para obtenção do título de Mestre em Artes, sob a orientação do Prof. ${ }^{\circ}$ Dr. ${ }^{\circ}$ Pedro Paulo Salles.

São Paulo 
Autorizo a reprodução e divulgação total ou parcial deste trabalho, por qualquer meio convencional ou eletrônico, para fins de estudo e pesquisa, desde que citada a fonte.

Catalogação da Publicação

Serviço de Documentação do Departamento de Música da Escola de Comunicações e Artes da Universidade de São Paulo

Delarole, Pedro Juliano.

O Conservatório Dramático e Musical "Dr. Carlos de Campos" de Tatuí como difusor cultural / Pedro Juliano Delarole; orientador Pedro Paulo Salles. - São Paulo, 2010. 172 f. : 1v. $30 \mathrm{~cm}$.

Dissertação (Mestrado) - Universidade de São Paulo, 2010.

1. História da Musica em Tatuí. 2. Educação Musical. 3. Historiografia. 4. Memória Iconográfica. 
Nome: DELAROLE, Pedro Juliano

Título: O Conservatório Dramático e Musical "Dr. Carlos de Campos" de Tatuí como difusor cultural

Dissertação apresentada à Faculdade da Escola de Comunicação e Artes da Universidade de São Paulo para obtenção do título de Mestre em Musicologia.

Aprovado em:

Banca Examinadora

Prof. Dr. Instituição:

Julgamento: Assinatura:

Prof. Dr. Instituição:

Julgamento: Assinatura:

Prof. Dr. Instituição:

Julgamento: Assinatura: 
À querida e virtuosa esposa Adriana, com amor e gratidão por sua compreensão, e incansável apoio ao longo do período de elaboração deste trabalho e por presentear-me com a existência de nosso filho João Pedro. 


\section{AGRADECIMENTOS}

Estamos em dívida com pessoas e com o conservatório de Tatuí, pela ajuda que nos prestaram para a realização deste trabalho.

Somos gratos pelo Prof. Pedro Paulo Salles na fase de orientação que nos incentivou, acreditando em sua realização e por suas valiosas recomendações; ao Prof. Diósnio M. Neto,

que colaborou com críticas oportunas e precisas. À Prof, ${ }^{a}$ Maria Eunice Moreira Rodrigues, que foi a pessoa decisiva desde o inicio, participando das etapas de produção, organização, mostrando-se detalhista e arguta em suas observações-mais que uma professora, uma amiga.

Devemos mencionar ainda o grande mestre Prof. Dr. Paulo Bosísio, Prof. de violino e viola José dos Santos, Carlos Blassioli e todos aqueles que me concederam as entrevistas necessárias e esclareceram pontos relevantes para minha pesquisa.

Impossível terminar sem mencionar o Prof. João Del Fiol, (in memoriam),figura crucial na criação e elaboração do conservatório de Tatuí, meu primeiro professor de violino, o qual tivemos o prazer de conviver por mais de dez anos e que nos compartilhou agradáveis memórias para que este trabalho se realizasse, porém não pode vê-las concluídas.

Ao Eterno, por Sua imensa benevolência em nossas vidas. 


\title{
RESUMO
}

DELAROLE, Pedro Juliano. O Conservatório Dramático e Musical "Dr. Carlos de Campos” de Tatuí como Difusor da Cultural. São Paulo, 2010. Dissertação de Mestrado na área de concentração Musicologia - Universidade de São Paulo - ECA/USP.

O delineamento desta pesquisa deu-se a partir da busca de informações históricas sobre as origens musicais da cidade de Tatuí - SP e da análise sócio-cultural da contribuição da música na sociedade local. Desta busca resultou o resgate das origens do Conservatório Dramático e Musical "Dr. Carlos de Campos" de Tatuí, enquanto organização e instituição estadual pública de educação musical formal. Como observador de uma organização que nasce da tradição musical de Tatuí e pelo envolvimento direto com esta escola - a problemática de pesquisa surge na reconstituição histórica da memória da instituição.

Palavras - chave: História da Musica em Tatuí, Educação Musical, Historiografia, Educação e Cultura, Memória Iconográfica.

\begin{abstract}
DELAROLE, Pedro Juliano. The Dramatic and Musical Conservatory "Dr. Carlos de Campos" of Tatuí as Cultura Musical Difusor. São Paulo, 2010. Dissertation of Master's Degree in Arts- University of São Paulo.

The design of this work starts at the search for historical data about the musical roots in Tatuí City -São Paulo - Brazil and from the social and cultural analysis on the contribution of music to the local society. Of this search resulted the rescue of the origins of the Dramatical and Musical Conservatory Dr. Carlos de Campos of Tatuí, while organization and public state institution of formal musical education. As a direct observer of an organization that was rised through the musical tradition of Tatuí, and for the direct evolvement with this school - the issue of this research appears from the institution's historical and memory rebuilding.
\end{abstract}

KeyWords: History of Music in Tatuí City; Musical Education; Historiography; Education and Culture; Iconography Memory. 


\section{REFERÊNCIAS ICONOGRÁFICAS}

Figura 1 - Vista parcial da Fábrica de Ferro de Ipanema. S/d. Fonte: Acervo do Instituto de Pesquisas e Estudos Morro de Araçoiaba. página -30

Figura 2 - Vista lateral da Fábrica de Ferro de Ipanema. S/d. Fonte: Acervo do Instituto de Pesquisas e Estudos Morro de Araçoiaba. página -30

Figura 3 - Vista parcial da frente da Casa da Guarda da Fábrica de Ferro de Ipanema. S/d. Fonte: Acervo do Instituto de Pesquisas e Estudos Morro de Araçoiaba. página -31

Figura 4 - Corporação musical de Tatuí. S/d. Fonte: Acervo de Marcelo Afonso...página - 32 Figura 5 - Corporação "União Operária" de Tatuí. S/d. Fonte: Acervo do Museu de Tatuí. .página -32

Figura 6 - Banda de Tatuí do início do século XX. S/d. Fonte: Acervo de Marcelo Ap. Afonso página -33

Figura 7 - Primeira fotografia da "Banda Santa Cruz", tirada em 1888. Fonte: Acervo Marcelo Ap. Afonso. página -34

Figura 8 - Corporação Musical "Santa Cruz”, início do século XX. Na segunda fila, o quinto músico, da esquerda para a direita, Praxedes de Campos, avô de Marcelo Afonso. S/d. Fonte: Acervo de Marcelo Afonso. página -35

Figura 9 - Banda "Santa Cruz", 1922. Fonte: Acervo de Marcelo Afonso página -35

Figura 10 - Banda "Santa Cruz", 1930. Fonte: Acervo de Marcelo Afonso. página - 36

Figura 11 - Banda "São Vicente de Paula", 1940. Fonte: Acervo do Museu de Tatuí. página - 36

Figura 12 - Corporação Musical "União Operária", 1935. Fonte: Acervo do Museu de Tatuí. .página -37

Figura 13 - Carnaval de 1927. Fonte: Acervo do Museu de Tatuí. página - 38

Figura 14 - Carnaval de 1939, Conjunto "Jazz União Operária" Tatuí. Fonte: Acervo de Marcelo Afonso página - 38

Figura 15 - Vista aérea do centro da cidade na década de 1950. Fonte: Acervo próprio página -40

Figura 16 - Carlos de Campos. Fonte: Acervo disponível na INTERNET: página -43

Figura 17 - Eulico Mascarenhas de Queiroz. Fonte: Acervo do CDMCC. página - 46 
Figura 18 - Inauguração oficial do Conservatório de Tatuí, 1954. Fonte: Acervo do Museu de Tatuí..... página -47

Figura 19 - Yolanda Rigonelli. Fonte: Acervo do CDMCC. página -52

Figura 20 - Comemoração da Semana da Música, 1962. 2ª Semana da Música Fonte: Acervo do Museu de Tatuí. página -53

Figura 21 - Reprodução da Ata da 16 ${ }^{a}$ Reunião Ordinária de 21/03/1964 Fonte: Acervo do CDMCC de Tatuí. páginas $-57,58,59,60,61,62$

Figura 22 - José Coelho na inauguração do novo prédio do CDMCC em 1969. Fonte: Acervo do CDMCC de Tatuí página -65

Figura 23 - Airton Pinto. Fonte: Acervo do CDMCC. página - 66

Figura 24 - Paulo Bosísio e Lílian Barreto. Fonte: Acervo do CDMCC página -67

Figura 25 - Guiomar Novaes. Fonte: Acervo do CDMCC. página -67

Figura 26 - Lançamento do disco de João Carlos Martins Fonte: Acervo do CDMCC página -68

Figura 27 - Amaral Vieira ao piano. Fonte: Acervo do CDMCC página - 68

Figura 28 - Reprodução da Ata da 24a Reunião Ordinária de 24/04/1969 Fonte: Acervo do CDMCC de Tatuí..... páginas $-69,70,71$

Figura 29 - Alunos matriculados de outros municípios de 1954 a 1975. Fonte: Acervo do CDMCC de Tatuí. página -72

Figura 30 - Total de alunos matriculados de 1954 a 1976. Fonte: Acervo do CDMCC de Tatuí...... página -72

Figura 31 - Maquete do auditório, 1970. Atualmente Teatro Procópio Ferreira do CDMCC de Tatuí. Fonte: Acervo do CDMCC de Tatuí página -74

Figura 32 - Ata da assinatura de construção do teatro em 20 de maio de 1970. Fonte: Acervo do CDMCC de Tatuí. página - 75

Figura 33 - Preparação do terreno para a construção do teatro. Fonte: Acervo do CDMCC de Tatuí. página - 75

Figura 34 - Parte interna do teatro em construção. Fonte: Acervo do CDMCC de Tatuí página - 76

Figura 35 - Parte interna do teatro terminado. Fonte: Acervo do CDMCC de Tatuí. página - 76

Figura 36 - Parte externa do teatro. Fonte: Acervo do CDMCC de Tatuí...... página -77 
Figura 37 - Recital: Valéria Póles e Aldo Vilani Fonte: Acervo do CDMCC de Tatuí..... página - 79

Figura 38 - Luiz Garcia. Fonte: INTERNET página -79

Figura 39 - Entrega do diploma de formatura pelas mãos do Diretor Coelho. Fonte: Acervo do CDMCC de Tatuí página - 80

Figura 40 - Matéria do Jornal "Sentinel" de Nashville de 10/05/1973 sobre a visita do prefeito de Nashville, EUA ao CDMCC de Tatuí, Bob Beckmeyer ao lado do prefeito de Tatuí, Paulo Ribeiro. Fonte: Acervo próprio página - 80

Figura 41 - O prefeito Bob Beckmeyer, de Nashville, EUA no CDMCC de Tatuí. Fonte: Acervo próprio página - 81

Figura 42 - I Festival de Jazz em São Paulo, 1976. Fonte: Acervo do CDMCC....página - 82

Figura 43 - Campeonato de Bandas, 1978. Diretor do CDMCC de Tatuí, José Coelho de Almeida, primeiro à direita. Fonte: Acervo do CDMCC. .página - 82

Figura 44 - II Encontro Paulista de Bandas, CDMCC de Tatuí, 1979. Fonte: Acervo do CDMCC página - 83

Figura 45 - Apresentação da Banda Sinfônica. Fonte: Acervo do CDMCC............página - 84 Figura 46 - Público presente no referido concerto. Fonte: Acervo do CDMCC.....página - 84 Figura 47 - Orquestra Infantil. Fonte: Acervo do CDMCC …................................página - 85

Figura 48 - Grupo Bach de violões. Fonte: Acervo do CDMCC............................página - 86

Figura 49 - Banda. Fonte: Acervo do CDMCC....................................................página - 86

Figura 50 - Coral. Fonte: Acervo do CDMCC.......................................................página - 87

Figura 50 - p Coral: Fonte: Acervo do CDMCC.....................................................página - 87

Figura 51 - Coral Juvenil. Fonte: Acervo do CDMCC............................................página - 87

Figura 52 - Grupo Lírico. Fonte: Acervo do CDMCC...........................................página - 88

Figura 53 - Música de Câmara.Fonte: Acervo do CDMCC.....................................página - 88

Figura 54 - Orquestra de Cordas.Fonte: Acervo de CDMCC.................................página - 89

Figura 55 - Sam Jazz. Fonte: Acervo do CDMCC................................................página - 89

Figura 56- Classe de Educação Musical. Fonte:Acervo do CDMCC......................página - 90

Figura 57 - Trio de Cordas. Fonte: Acervo do CDMCC..........................................página - 90

Figura 58 - Orquestra Sinfônica, regência Maestro Jamil Maluf. Fonte: Acervo do CDMCC página - 91

Figura 59 - Apresentação do CDMCC SP.em 1980. Fonte: Acervo do CDMCC..página - 91 
Figura 60 - Jubileu de prata do CDMCC, 1979. Fonte: Acervo do CDMCC.........página - 92 Figura 61 - Semana da Pátria-Exposição dos instrumentos. Fonte: Acervo do CDMCC página - 92

Figura 62 - Exposição de instrumentos.Fonte: Acervo do CDMCC........................página - 93

Figura 63 - Exposição de instrumentos. Fonte: Acervo do CDMCC......................página - 93

Figura 64 - Exposição de instrumentos. Fonte: Acervo do CDMCC.......................página - 94

Figura 65 - H. J. Koellreutter. Fonte: Acervo INTERNET.....................................página - 96

Figura 66 - Antonio Carlos Neves de Campos. Fonte: Acervo do CDMCC.............página - 98

Figura 67 - Anexo 3. Fonte: Acervo do CDMCC.................................................página - 100

Figura 68 - Anexo 4. Fonte: Acervo do CDMCC.................................................página - 101

Figura 69 - Anexo 5. Fonte: Acervo do CDMCC...............................................página - 101

Figura 70 - Anexo 6. Fonte: Acervo do CDMCC..................................................página - 102

Figura 71 - Visão noturna do Teatro Procópio Ferreira. Fonte: Acervo do CDMCC página - 111

Figura 72 - Escultura feita pelo prof. Josué F. Pires. Fonte: Acervo do CDMCC .página -112

Figura 73 - Alunos do CDMCC. Fonte: Acervo do CDMCC................................página - 112

Figura 74 - Formandos do curso de piano. Fonte: Acervo do CDMCC.................página - 115

Figura 75 - Grupo de Arte Cênica. Fonte: Acervo do CDMCC............................página - 120

Figura 76 - Big Band do CDMCC. Fonte: Acervo do CDMCC......................página - 120

Figura $77-47^{a}$ Semana da Música. Fonte: Acervo do CDMCC...........................página - 121

Figura 78 - Grupo de Choro. Fonte: Acervo do CDMCC......................................página - 121

Figura 79 - Orquestra de Cordas Infantil “Da Capo”. Fonte: Acervo.....................página - 122

Figura 80 - Orquestra “João Del Fiol”. Fonte: Acervo do CDMCC.......................página - 122

Figura 81 - Curso de Luteria. Fonte: Acervo do CDMCC...................................página - 123

Figura 82 - Banda Sinfônica. Fonte: Acervo do CDMCC....................................página - 123

Figura 83 - Big Band Sam Jazz. Fonte: Acervo do CDMCC...........................página - 124

Figura 84 - Camerata Octopus. Fonte: Acervo do CDMCC.................................página - 124

Figura 85 - Orquestra sinfônica. Fonte: Acervo do CDMCC.................................página - 125 


\section{LISTA DE ABREVIATURAS}

CDMCC - Conservatório Dramático e Musical "Dr. Carlos de Campos” de Tatuí.

IBAMA - Instituto Brasileiro do Meio Ambiente e dos Recursos Naturais Renováveis. 


\section{SUMÁRIO}

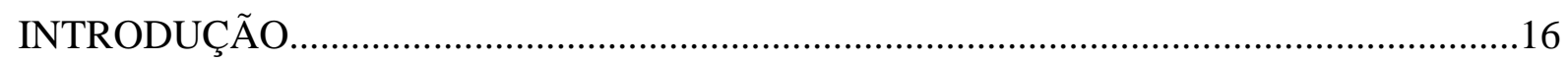

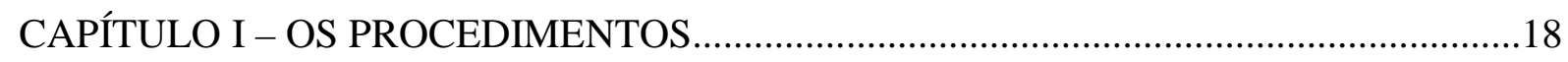

CAPÍTULO II - PATRIMONIO CULTURAL E MEMORIA: UM ESTUDO DAS

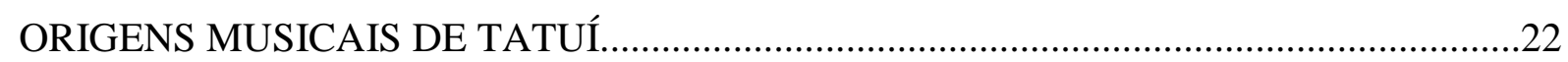

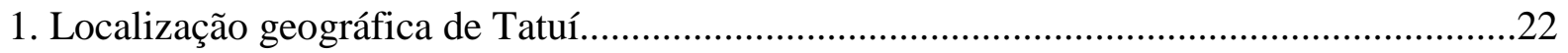

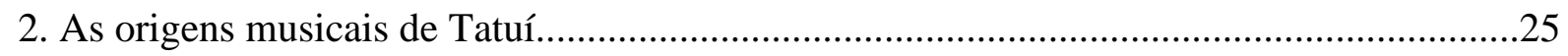

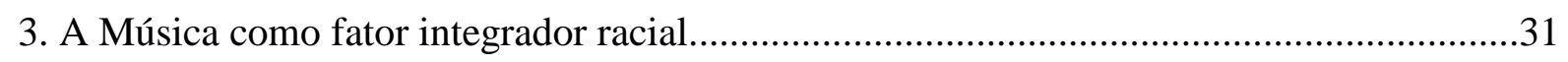

4. O panorama social e organizacional de uma época............................................................37

5. A idealizaçãa do conservatório de Tatuí ...........................................................................40

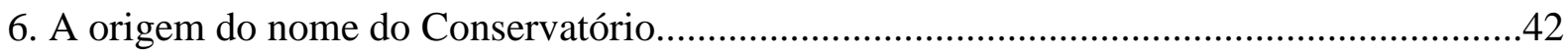

CAPÍTULO III - O PRIMEIRO DECÊNIO DO CONSERVATÓRIO DE TATUÍ (1954-

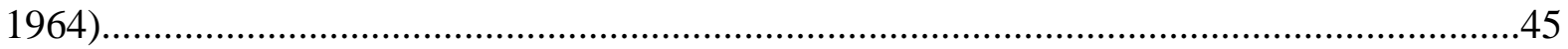

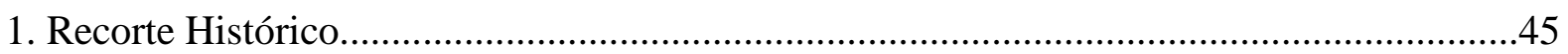

2. O Primeiro Diretor do Conservatório de Tatuí - Eulico Mascarenhas de Queiroz

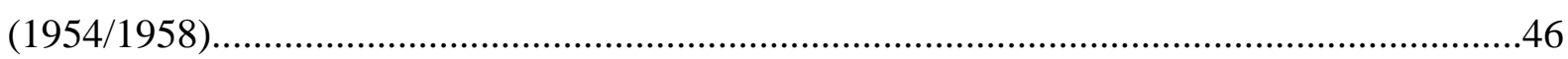

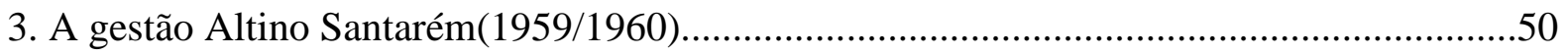

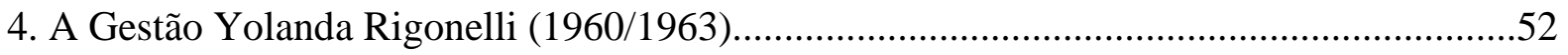

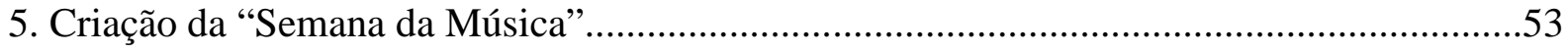

CAPÍTULO IV - O CONSERVATÓRIO DRAMÁTICO E MUSICAL “DR. CARLOS DE CAMPOS” DE TATUÍ NO PERÍODO DA DITADURA MILITAR....................................56

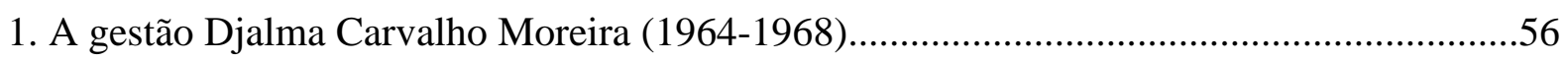

2. A gestão Professor José Coelho de Almeida (1968-1983).................................................64

3. A projeção do Conservatório de Tatuí no cenário artístico brasileiro e internacional..........66

CAPÍTULO V - AS MUDANÇAS NA POLÍTICA CULTURAL BRASILEIRA..................96

1. A gestão Hans Joaquim Koellreutter (1983-1984) ...............................................................96

2. A gestão Antônio Carlos Neves Campos (1984 -2007).......................................................98

CAPÍTULO VI - A MÚSICA, A CULTURA E OS VALORES: UMA ANÁLISE SOBRE AS ORGANIZAÇÕES CULTURAIS CRIATIVAS E AS BUROCRÁTICAS....................104 


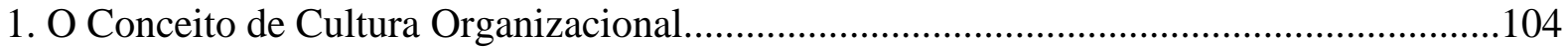

2. A Música Como Produção Cultural................................................................................106

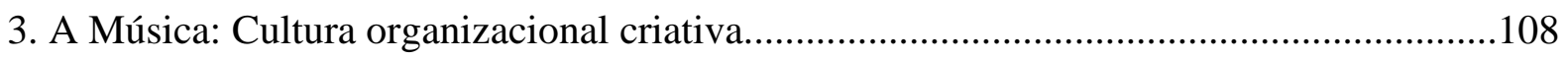

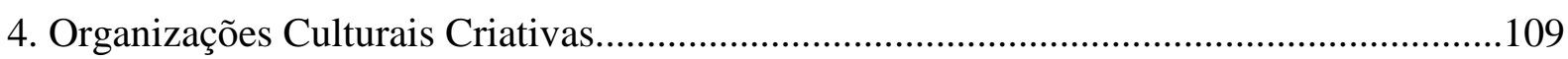

5. O Conservatório Dramático e Musical "Dr. Carlos de Campos” de Tatuí como Modelo

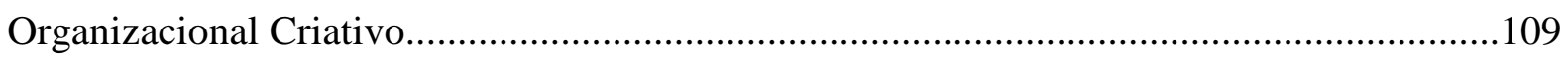

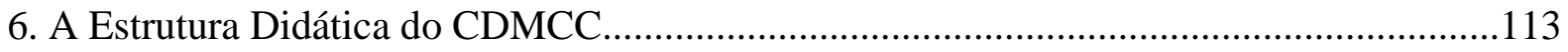

7. Ensinar: uma Arte, uma Ciência - Sentido de Pertencimento............................................125

8. O Conservatório de Tatuí na Modernização Reflexiva.....................................................128

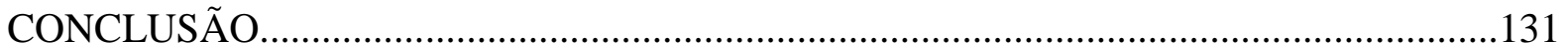

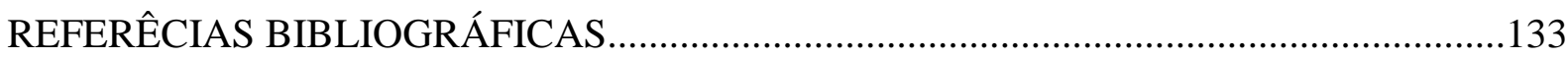

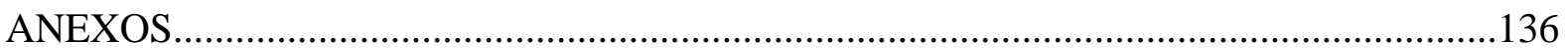

A - Transcrição: Ata da 16 ${ }^{a}$ Reunião Ordinária de 21/03/1964 ...............................................136

B - Transcrição: Ata da $24^{a}$ Reunião Ordinária de 24/04/1969.............................................138

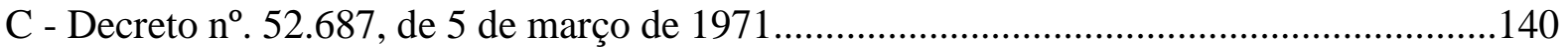

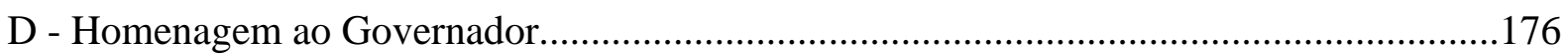


"Uns podem fazer aquilo que querem. Outros não podem e sofrem bastante.

Que escrevam sobre isso"

(William Faulkner) 


\section{INTRODUÇÃO}

Este estudo - na área de Musicologia, Cultura, Educação e Comunicação - pretende fomentar o diálogo e a reflexão sobre as políticas culturais que se encontram na origem e continuidade do Conservatório Dramático e Musical "Dr. Carlos de Campos" de Tatuí, inserido no contexto social, político pedagógico e das novas mudanças educacionais ocorridas no início do século XXI.

Devido à ausência de estudos e pesquisas anteriores a este, sobre a história e outros aspectos dessa instituição, foi necessário traçar um panorama histórico, tendo como base a coleta de dados de diferentes naturezas, que possibilitassem uma análise posterior. As análises tenderam a incidir quase sempre sobre recortes cronológicos ou temáticos da história da instituição, por meio de entrevistas com pessoas envolvidas no processo político-cultural do projeto de sua criação, bem como pessoas ligadas atualmente com a instituição (diretor, professores, funcionários), sendo que a base historiográfica constituiu-se de legislações, documentos oficiais, artigos de jornais, atas, iconografia e todo tipo de base documental dos períodos históricos da instituição, para que possibilitassem a comprovação e a veracidade dos fatos, contribuindo para a reconstituição histórica e para a memória da instituição.

A produção do conhecimento histórico implicou na recuperação da memória, e a indagação que permeou a pesquisa ensejou compreender o fenômeno musical em Tatuí como mecanismo estruturado e sistema organizacional que possibilitou, a um determinado grupo de pessoas, implantar o Conservatório Dramático e Musical "Dr. Carlos de Campos" de Tatuí no contexto da cultura musical da cidade, do Estado de São Paulo e do Brasil.

Entendendo esta instituição como um dos mais sérios e bem sucedidos difusores culturais brasileiros, pretendeu-se visitar os caminhos percorridos pelo Conservatório de Tatuí, no sentido de contribuir com elementos que possam servir a novas pesquisas e permitam abordar as políticas envolvidas com a produção cultural do país e sua repercussão. O enfoque metodológico, a história regional em torno dos movimentos sociais e culturais desta pesquisa, de certa maneira instigará a que tomemos como aportes importantes o fazer histórico e as novas formas organizacionais, abordando a importância do desempenhar histórico-cultural enquanto ferramentas de apoio ao entendimento da formação musical no Brasil, tendo como referencial o Conservatório de Tatuí.

Ao questionarmo-nos sobre como as identidades culturais musicais são construídas e organizadas, vi-nos conduzidos a buscar e a aprofundar nos fenômenos culturais que 
motivaram os processos da história musical da cidade, para desenvolver o tema desta dissertação de mestrado. Percorremos os caminhos de pessoas que, independentemente da falta de uma política cultural eficiente no país, se organizaram e difundiram a cultura musical, propiciando a oportunidade de "criação" do Conservatório de Tatuí, esta instituição que tanto reflete quanto foge às regras culturais do país, pois nasceu sob o estigma do fracasso, mas conseguiu tornar-se uma das instituições de ensino de música mais respeitada do país.

O capítulo I trata dos procedimentos utilizados para a consecução da pesquisa, especialmente dos que dizem respeito à busca da memória através da coleta de material e de depoimentos, a escolha do material e a sistematização dos discursos dos depoentes.

O capítulo II traça o resgate histórico das origens da cidade e de sua "vocação" musical. Foi estruturado através de leitura iconográfica, das atas do CDMCC de Tatuí, dos relatos de várias pessoas que vivenciaram o período da idealização e fundação da escola e da política cultural vigente. Essa temática é aprofundada quando se aborda o início do CDMCC de Tatuí como instituição governamental e seus avanços no campo musical.

A atividade humana entendida como ação consciente, dotada de sentido e subjetivamente orientada, o traço de união entre as organizações criativas e sua fenomenologia social, foram abordados no capítulo III, IV e $\mathrm{V}$ através do levantamento histórico dos antigos diretores que passaram pela instituição e as modificações ocorridas durante esse período historiográfico, social e cultural do CDMCC de Tatuí, bem como a sua evolução no cenário musical, visto na atual modernização reflexiva. 


\section{CAPÍTULO I}

\section{OS PROCEDIMENTOS}

Os seres humanos distinguem-se dos demais animais, entre outras coisas, pela constante atualização e complexidade da memória. Na rica fenomenologia da lembrança, o registro do passado é parte da necessidade humana de refletir, é a aspiração de explicar a origem das experiências vividas, para uma compreensão do presente e uma antecipação do futuro.

Para responder sobre sua existência atual e conhecer a si mesmo, os seres humanos têm de mergulhar no seu passado. Através da História, buscamos nossa identidade para compreender o momento presente, podendo essa compreensão ocorrer sob pontos de vista culturais, sociológicos e antropológicos. As memórias, a maneira mais comum de conservar as histórias, elaboradas a partir de relatos orais das lembranças, pela coleta de depoimentos e pelo diálogo entre o entrevistado e o pesquisador, permitem que estabeleçamos a relação entre presente e passado. O resultado dessa relação, isto é, da produção intencional da memória como fonte histórica que apresenta afinidades tanto quanto especificidades em relação à outra espécie de documentação, interfere na preservação da memória entendida como processo de representações ontológicas.

A singular participação do pesquisador na construção do registro seletivo da memória, através do cuidadoso processo de indagar, de reconstituir, de rememorar, o torna parceiro do seu entrevistado. Ao compartilhar a lembrança, sua narrativa conserva o que foi significativo para cada entrevistado e amplia o âmbito do relato autobiográfico. Entrevistador e entrevistado envolvem-se no objetivo de fazer surgir à memória como força profunda e ativa para compor um discurso comum.

Este primeiro capítulo se dedica a apresentar de maneira sistemática os procedimentos da pesquisa sobre o CDMCC de Tatuí e a explicitar as etapas de observações e análises exploratórias próprias do trabalho de campo, fontes documentais e indicadores que fornecessem uma imagem do conjunto dos contextos históricos. Tentamos obter informações e dados recolhidos em entrevistas para compor um quadro relativamente completo sobre a idealização e trajetória histórica do CDMCC de Tatuí, inseridas num contexto interpretativo 
próprio, qual seja o do estudo da musicologia e das culturas organizacionais em diferentes espaços educacionais e de trabalho.

O interesse em escolher o Conservatório de Tatuí como tema deveu-se à ligação que tenho com a instituição. Sendo ex-aluno, atualmente professor e gestor da área de cordas e também Spalla da orquestra local denominada Orquestra Sinfônica do Conservatório de Tatuí, possibilitou e me possibilitam a participação em algumas das transformações ocorridas nos últimos vinte anos, transformações que sempre foram cercadas de grande repercussão dentro da instituição e na cidade. Desta perspectiva vislumbrou-se a possibilidade da pesquisa de dissertação iniciar a indagação sobre a importância da cultura musical do CDMCC de Tatuí e sobre a formação do comportamento dos músicos e da sociedade local.

Ao músico/historiador cabe percorrer o caminho intermediário entre a identificação do seu objeto de estudo e sua interpretação. As etapas na memória são divididas por marcos e pontos onde o significado da vida do entrevistado se concentra. Revelou-se extremamente elucidativo para o objeto de estudo o trabalho de análise com a descrição e a sistematização cronológica dos dados coletados durante a pesquisa. Grande parte da lembrança histórica corresponde a ausências, perdas, ao que foi excluído, ao que deixou de ser registrado, por não fazer parte de acontecimentos e mudanças profundas na vida regional e cultural de cada entrevistado e da cidade de Tatuí; porém, quando trabalhamos com preservação da memória, devemos lembrar que memória e esquecimento fazem parte de um mesmo processo, em que as lacunas são sempre elucidativas.

As entrevistas de histórias de vida e lembranças de membros e ex-membros do CDMCC de Tatuí envolvem algumas especificidades inerentes ao próprio objeto de estudo. Uma entrevista não se constitui isoladamente, é parte integrante de um pressuposto básico para a produção de conhecimento. Certamente ao problematizar as entrevistas, as limitações e a difícil transcrição do discurso oral para o escrito - mais presentes nos capítulos II, III e IV são mostrados pelo próprio processo de registro da memória e da experiência de pessoas ligadas ao Conservatório de Tatuí que delineiam subjetividades e afetos da instituição.

O problema mais sério encontrado pelo musicólogo, quando elabora o levantamento do patrimônio documental e iconográfico de uma instituição, é ultrapassar os limites do poder de quem detém e disponibiliza o acesso. $\mathrm{O}$ acervo iconográfico e o patrimônio documental de uma instituição permitem o acesso a uma versão do passado, ou seja, ao modo pelo qual a instituição preserva seu passado. Registrar a história é reconstruí-la através das múltiplas versões veiculadas pelos atores que viveram acontecimentos e conjunturas do passado, tanto 
quanto organizar documentos, aos quais, muitas vezes, o acesso passa por múltiplos labirintos.

Que tenhamos conhecimento, é a primeira vez que se efetua um trabalho dessa natureza, ou seja, a idealização e trajetória histórica do CDMCC de Tatuí, um trabalho que, na medida do possível, forneça simultaneamente informações detalhadas e sistemáticas tanto sobre a trajetória histórica, como a política e a cultural do CDMCC de Tatuí.

A coleta de entrevistas passou pelos procedimentos de escolha dos depoentes, visita e registro fonográfico e/ou visual dos depoimentos. Numa segunda etapa se procedeu à transcrição dos mesmos diretamente para o texto e, numa terceira, pelo "recorte" das informações a que se referiram as determinadas passagens da constituição do CDMCC. A análise do conteúdo englobou basicamente o aspecto histórico presente no discurso, com o detalhamento de elementos constitutivos discursivos dos depoimentos.

A coleta de documentos escritos e de registros iconográficos realizou-se em acervos particulares, do CDMCC e do Museu Paulo Setúbal de Tatuí. Igualmente, estes documentos passaram pelo crivo de uma leitura histórica que fosse capaz de fazer emergir tanto os aspectos próprios às peculiaridades da origem da tradição musical em Tatuí, quanto aqueles referentes à idealização e concretização do CDMCC. 
"Quando procurei formar a minha cultura, guiado pelo meu próprio instinto e tirocínio, verifiquei que só poderia chegar a uma conclusão de saber consciente, pesquisando, estudando obras que, à primeira vista, nada tinham de musicais. Assim, o meu primeiro livro foi o mapa do Brasil".

(Heitor Villa-Lobos) 


\section{CAPÍTULO II}

\section{PATRIMÔNIO CULTURAL E MEMÓRIA: UM ESTUDO DAS ORIGENS MUSICAIS DE TATUÍ}

\section{Localização geográfica de Tatuí}

Tatuí, palavra de origem Tupi que significa "rio dos tatus", situa-se na região oeste do Estado de São Paulo, tendo como limites ao sul, a cidade de Itapetininga, ao norte, Cerquilho, à oeste, Guareí e a leste, Boituva, Iperó e Capela do Alto.

Atualmente Tatuí conta com população de 105.030(IBGE/2005) e 70.386 eleitores, tendo como fator de desenvolvimento a indústria têxtil. Está distante $137 \mathrm{~km}$ da capital do Estado, $110 \mathrm{~km}$ de Campinas e $60 \mathrm{~km}$ de Sorocaba, tendo como rodovias de principal acesso a Castello Branco, (SP 280), Rodovia Raposo Tavares (SP 270), Rodovia Senador Laurindo Dias Minhoto (SP 141) e Rodovia Antonio R. Schincariol (SP 127), proporcionando facilidades de acesso a todas grandes cidades do Estado de São Paulo.Situada a uma altitude de 645 metros do nível do mar e constituída de terrenos planos com pequenas elevações, com solo de sedimentos areníticos com camadas calcárias. Seu clima é quente, com inverno seco e temperatura amena.

Para chegar na sua forma atual, Tatuí, o vocábulo nasceu Tatuuvu, passou a Tatuhibi, Tatuy e Tatuhy.

O sociólogo e professor Antônio Candido (1981:39) fez o seguinte apontamento em seu livro "Os Parceiros do Rio Bonito":

"Comecemos pelos tipos de povoamento, a partir da primeira ocupação da terra [...], a fixação principia com os descobridores de minas, interessados em explorar a terra. Multiplicam-se vilas, povoados, [...].

O advogado Laurindo Dias Minhoto, na obra "Tatuhy Através da Historia”, s/d, pág. 138, cita:

"O mais remoto documento, que conseguimos descobrir, foi a carta de sesmaria concedida em 10/11/1609, pelo Conde da Ilha do Príncipe, por seu procurador Thomé de Almeida Lara, sendo aquele donatário da Capitania de São Vicente. Essa concessão foi feita a João de Campos e ao seu genro Antônio Rodrigues e nela se lê : " seis legoas de terras no districto da villa 
de Nossa Senhora da Ponte (Sorocaba), na parragem denominada Ribeirão de Tatuí, com todos os campos e restingas para pastos de seu gado, como também Tatuí-mirim thé o Canguera, com largura que tiver, com mais trez legoas em quadra no Tatuí - guassú e Canguary, trez legoas para o caminho de Intucatú ,seis legoas correndo paraguary abaixo para a parte do Paranapanema, com condição de pagar os dísimos a Deus Nosso Senhor dos productos que dellas colherem."

Segundo a Revista Tatuí (1987) - edição comemorativa 50 anos sem Paulo Setúbal.

"De acordo com o Dicionário Geográfico de J. C. R. Millet de Saint Adolphe, a origem de Tatuí, foi um sítio agreste do distrito da cidade de Sorocaba”.

No início do século XVIII, os padres da Companhia de Jesus já tinham fazendas de criar gado nos campos de Guareí e Alto da Serra de Botucatu, ligadas entre si por caminhos que passavam pela parte meridional do atual município de Bofete, na zona do rio, desde então denominado significativamente.

Santo Inácio. Mais tarde, pelo fim do século, um caminho saindo de Sorocaba buscava o Paranapanema, passando por Bofete, também, na sua parte sul. Mas os agrupamentos de origem européia só aparecem (nessa região) em pleno século XIX, sob a forma de fazendas e sítios, polarizados por Tatuí, na maior parte, e por Botucatu os se que localizavam nas fraldas da serra. No início, eram moradores isolados e, em seguida, com entorno da capela, em patrimônio doado, surgiam as primeiras lojas e algumas casas. Passava a freguesia, já com o núcleo de população esboçado. O povoado subia à vila, chegando afinal a cidade. Nesses casos, a população rural ia se ampliando na periferia, onde apareciam novos bairros que passavam à vila e, assim, sucessivamente. Na direção de Botucatu, o acesso ao planalto se tornava bastante difícil pela serra, cujos morros fechavam a passagem para o sul, atingindo, também, àqueles que vinham de Tietê e os que desciam de Anhembi, e, apenas para o lado de Porangaba e Tatuí as comunicações eram desimpedias para o lado de Bofete; por aí, certamente, penetraram povoamento e cultura européia naquela direção.

Bandeirantes se instalaram no encontro dos rios Sorocaba e Tatuuvu, à procura de ouro, por volta de 1680. Os irmãos Paschoal e Jacynto Moreira Cabral, responsáveis pelo achado, acompanhavam o Frei Pedro de Souza nas explorações do Morro de Araçoiaba, em busca de metais. Anos depois, os dois irmãos junto com Manoel Fernandes e Martins Garcia Lumbria, autorizados por Carta Régia datada de 5/02/1682, levantaram a Fábrica de Ferro de Ipanema em Araçoiaba da Serra e fundaram a povoação de Nossa Sra. Del Popollo, que obteve o título de Paróquia.

\footnotetext{
${ }^{1}$ Minhoto, Laurindo Dias, Tatuhy Através da História pág.138, S/d. e S/ed.
} 
Devido às informações contraditórias não sabemos ao certo quando tem início a história de Tatuí. Portanto achamos conveniente considerar as datas entre 1812 e 1817, com a chegada dos habitantes de origem européia que arrendaram terras nos campos de Bacaetava e Guaxingú, que pertenciam aos frades de Itu, as datas mais apropriadas.

Quatro anos depois, em 11 de agosto de 1826, o Brigadeiro Manoel Rodrigues oficializou a venda dos lotes ocupados pelas famílias. Os primeiros compradores foram Francisco Xavier de Freitas e Gerônimo Fiuza. Posteriormente instalaram-se nesse local as famílias de Manoel Guedes, José Marques, Francisco de Campos e Jordão Vieira de Campos, todos provenientes de Itu. Fundada como vila em 11 de agosto de 1826 por Brigadeiro Manoel Rodrigues Jordão e elevada à categoria de município pela Lei Provincial $n^{\circ} .12$ de 13 de fevereiro de 1844, após ser desmembrada do município de Itapetininga.

Com ajuda de frades de São João do Benfica, que queriam ver a vila transposta para o território em que hoje se encontra a cidade, Tatuí teve sua demarcação realizada pela Câmara de Itapetininga e concluída em 11 de Agosto de 1826, data que passou a ser adotada como de sua fundação. Elevada a vila em 13 de fevereiro de 1844, tornou-se cidade em 20 de julho de 1861 e Comarca de Tatuí em 7 de Maio de 1877.

No dia 11 de Julho de 1888, inaugurou-se a estrada de ferro Sorocabana, com estação em Tatuí. No dia 28 de Janeiro de 1890, foi nomeada a Primeira Intendência, composta dos Srs. Antonio Moreira da Silva, Nicolau Magaldi, Francisco Carlos Baillot e José Pinto Moreira Drumond.

Em 1823 a cidade passou por um surto de extraordinário progresso, contando com 800 prédios na zona urbana e vária industrias. Os pioneiros foram Antonio Xavier de Freitas e Gerônimo Antonio Fiuza, em cujas terras por eles arrendadas iniciou-se a formação de diversos focos populacionais.

Parte das pessoas que vieram posteriormente eram invasores das terras e acabaram tendo que deixar as propriedades. Sem ter para onde ir, eles recorreram aos frades de quem ganharam uma gleba nas proximidades do rio Tatu-uv (atual bairro de Americana), onde foi fundada a primeira capela do município, denominada de São João do Benfica.

Tatuí é atualmente conhecida como "Capital da Música", onde parte de sua população está inserida no contexto nacional da música devido ao Conservatório Dramático e Musical "Dr. Carlos de Campos" de Tatuí, que durante longo período foi o único, no interior do Estado, a ser mantido pelo governo do Estado e, somente no final do século XX, viria a ser vinculado à Universidade Livre de Musica Tom Jobim de São Paulo atual EMESP. 
O CDMCC de Tatuí pode ser considerado como o fator de maior desenvolvimento da cidade, pois gera empregos e, nacionalmente, a cidade é considerada como um celeiro musical, provendo músicos para orquestras dentro e fora do país.

\section{As origens musicais de Tatuí}

Para um melhor entendimento do processo social, político e cultural da região, se faz necessário uma breve introdução sobre as origens musicais de Tatuí, que está intimamente ligada à primeira siderúrgica nacional, isto é, nas minas de ferro do "Morro do Ipanema", unidade de conservação do IBAMA $^{2}$, onde pode ser visto até hoje a "Real Fábrica de Ferro de São João de Ipanema", localizada entre as cidades de Iperó, Araçoiaba da Serra e Sorocaba, considerado um dos pontos turístico do Estado de São Paulo, devido ao conjunto de monumentos históricos que marcaram o início da siderurgia brasileira.

Propriedade do Governo desde a sua existência, a área da Fazenda Ipanema foi foco constante de inúmeras iniciativas pioneiras no campo da geologia, mineralogia e siderurgia, principalmente em função das reservas minerais existentes na Serra Araçoiaba, localizada dentro de seus limites, o que atraía a atenção e a cobiça dos administradores e políticos, desde a época da colonização.

Com mais de cinco mil hectares de área, a Floresta Nacional de Ipanema, em Iperó, possui papel relevante na História Econômica do Brasil. A região da Fazenda Ipanema representa um marco na história da siderurgia brasileira e atualmente, na história ecológica do sudeste brasileiro. Esta localidade serviu como ponto de parada obrigatória para diversos naturalistas, como Saint-Hilaire, Lund, Martius, Spix e Natterer que, no século XIX, percorreram o interior do Brasil. Johann von Natterer, naturalista austríaco, esteve em Ipanema entre 1819 e 1822, período no qual coletou representantes de 343 espécies da avifauna regional, demonstrando a riqueza avifaunística existente na época, quando então, a cobertura vegetal era contínua e pouco antropizada.

Nessas terras, em 1589, foi levantada a primeira forja de ferro do país e também a primeira siderúrgica nacional, em 1818. A localização fica entre Iperó, Araçoiaba e Sorocaba, denominando-se Ipanema, onde começou a se propagar à fabricação do ferro brasileiro. Foi

\footnotetext{
${ }^{2}$ Instituto Brasileiro do Meio Ambiente e dos Recursos Naturais Renováveis, IBAMA.
} 
neste morro que os irmãos Cabral e Manoel Fernandes de Abreu e Martins Lumbria, autorizados por carta régia de 5 de maio de 1682, levantaram a fábrica de ferro do Ipanema, em Araçoiaba. Pascoal Moreira Cabral fundou também a povoação de Nossa Senhora Del Papolo, que existiu no distrito de Sorocaba e que, segundo a tradição, deu origem à atual cidade de Tatuí.

Os dados históricos sobre a fazenda ensinam que no ano de 1589 o homem branco penetrou pela primeira vez na região então habitada pelos índios Tupiniquins. De 1597 em diante, a região de Ipanema foi palco de várias tentativas de exploração da riqueza mineral ali existente.

Na montanha próxima, chamada pelos índios de "Araçoiaba" (o lugar onde o Sol se esconde), o primeiro bandeirante, Afonso Sardinha, o velho, e seu filho, chamado de o "Mameluco", descobriram ferro, diorito e outros minerais. Estabeleceram então dois fornos rústicos de fundição, denominados "fornos catalãos" que, já no final do século XVI, se encontravam em plena atividade. Desde a chegada do homem branco na região, por meio da "Bandeira" de Afonso Sardinha, o Morro de Araçoiaba, tem sido constantemente modificado pelo homem. A partir dessas primeiras tentativas de exploração do ferro, a vegetação do Morro começou a sofrer as primeiras interferências antrópicas.

Segundo o historiador Carvalho Franco, (1964:13):

$$
\begin{aligned}
& \text { "as iniciativas ganharam relativo impulso a partir de } 1589 \text {, quando Afonso } \\
& \text { Sardinha, o moço, com Clemente Álvares e uns poucos companheiros mais, } \\
& \text { descobriram ouro e ferro em vários lugares ao entôrno da vila sertaneja, } \\
& \text { chegando mesmo a construir dois fornos catalães para o preparo do ferro, } \\
& \text { junto ao morro do Araçoiaba".] }
\end{aligned}
$$

Apostando na existência de ouro na região, comunicaram o feito ao Governador Geral do Brasil, D. Francisco de Souza, que chegou ao local em 1611. Em sua visita, o Governador Geral elevou o povoado ali existente à categoria de vila com o nome de "Nossa Senhora de Monteserrate do Itapevussú". Porém, pouco interessado no minério de ferro, acabou dando por encerrado o empreendimento, que cessou em meados do ano de 1615. Com isso, os habitantes da vila acabaram se espalhando pela região, dando início a formação de outros vilarejos, um deles hoje conhecido por Itavuvu e a vila que acabou se transformando na Sorocaba de hoje.

Depois de Sardinha, em 1680 houve uma nova tentativa por parte dos irmãos Moreira Cabral e do Duque de Lumbria, em formar um outro estabelecimento de fundição, mas que acabou fracassando ápos cinco anos de esforços. Nova tentativa foi levada a efeito no tempo do Morgado de Mateus, por Domingos Pereira Ferreira e o capitão Jacinto José de 
Abreu. Em 1766 construíram novos fornos, de estilos africano e catalão, mas novamente a atividade não durou mais do que seis anos.

Somente com a ascensão de D. João VI ao poder, e com o estabelecimento do Reino Unido de Portugal, Brasil e Algarve, já no século XIX, houve a primeira iniciativa séria de se estabelecer uma fundição de grande porte nas terras de Ipanema. Após a chegada da família real ao Brasil em 1808, Dom Rodrigo de Souza Coutinho, Ministro da Guerra do Governo Português, Conde de Linhares, foi autorizado a desenvolver os planos siderúrgicos, por determinação de D. João. Com essa finalidade o ministro chamou Frederico Luiz Guilherme Varnhagem, engenheiro alemão, que junto com Martim Francisco de Andrada, seguiram para a região estudando e analisando o solo. Descobriram várias jazidas do metal e apresentaram ao Conde de Linhares um minucioso relatório, já com o esboço de plano de exploração do local. O Conde Linhares mandou proceder, da Suécia o recrutamento de pessoal técnico, fundidores e mineiros, chefiados por Carlos Gustavo Hedberg, especialista em dirigir fundições e forjas na Europa.

Em 4 de dezembro de 1810, era publicada carta régia, criando o "Estabelecimento Montanístico das Minas de Ferro de Sorocaba 3", para a extração do ferro que existia na mina da Capitania de São Paulo. Diz a carta:

[...] Fui servido mandar vir da Suécia uma colonia de bons mineiros, com um hábil diretor para dirigir os trabalhos, Carlos Gustavo Hedberg. A escolha de Hedberg, cidadão e vassalo sueco, como idônio e apto para construir fornos e, depois dirigir a fábrica de ferro, foi feita pelo Dr. Gustavo Beyer, médico sueco de grande renome, cavalheiro e assessor da Real Ordem da WASSA, consul português na Suécia. O contrato de Hedberg foi feito por dez anos. Sua administração não deu certa.

Hedberg foi nomeado diretor do projeto, com um contrato de 10 anos. O Conde de Linhares criou uma junta administrativa e econômica, formada por quatro membros, dentre eles Frederico Varnhagem.

Após estudos de Martim Francisco de Andrada, o sueco Dr. Hedberg foi incumbido de chefiar o recém formado "Estabelecimento Montanístico das Minas de Ferro de Sorocaba". Ele efetuou várias construções de grande porte, construindo as primeiras rodas d'água para fins de serraria no Brasil, montou uma ponte, represou o rio Ipanema com a construção de vários canais para obtenção de força hidráulica e estabeleceu uma fábrica de ferro. Sem obter êxito com o empreendimento, pois possuía conhecimentos de Engenharia Civil, mas nenhum sobre siderurgia. Os "hábeis mineiros" eram na realidade um músico, um cozinheiro, um sacristão. O sueco Dr. Hedberg foi substituído pelo Major de Engenheiros do Exército

\footnotetext{
${ }^{3}$ Primeiro nome da Fábrica de Ferro de Ipanema.
} 
Alemão comissionado em Portugal, Frederico Guilherme Varnhagen, que construiu dois altos fornos no local, lançando mão de um novo sistema de "corrida de ferro" (o ferro liquefeito) no Brasil, em 01 de novembro de 1818.

Ao passar por ali em 1818, os naturalistas alemães Spix e Martius registraram ${ }^{4}$ :
"Os imponentes prédios da fábrica e a impressão de atividade e de indústria ruidosa transportaram-nos, por assim dizer, a uma região laboriosa e de beleza selvagem de nossa pátria". O que tanto agradou aos viajantes foi o primeiro grande projeto de siderurgia no Brasil, a Real Fábrica de Ferro de Ipanema, perto da então vila de Sorocaba. As jazidas de ferro do morro Araçoiaba já eram conhecidas desde quando os primeiros bandeirantes atravessaram a serra local, mas foi só depois da vinda da família real portuguesa para o Brasil em 1808 que a exploração sistemática foi iniciada. D. João VI mandou trazer da Suécia uma colônia de mineiros e fundidores, e o ferro começou a ser fabricado ali em 1813".

A já então chamada Real Fábrica de Ferro de Ipanema funcionou por todo o século XIX, produzindo cerca de duas toneladas de ferro por dia. Por ela passaram vários diretores que foram acrescentando novas construções e instalações. O último deles, o Coronel Joaquim Antonio de Souza Mursa, construiu na fábrica um grande alto forno, que produzia cerca de sete toneladas de ferro por dia. A fábrica, contudo, acabou sendo desativada pelo Governo da recém-República, por problemas econômicos e administrativos e teve encerrada suas atividades em 1895. O que restou de todos os fornos, inclusive os do século XVI, ainda sobrevive precariamente no local.

$\mathrm{Na}$ falta de mão de obra especializada e de capital, o trabalho era feito de forma rudimentar por sertanistas, índios e escravos. Dessa forma com altos e baixos.

Nas primeiras reuniões Varnhagem e Hedberg já apresentaram opiniões contrárias em determinados pontos. Hedberg pretendia construir quatro fornos pequenos, Varnhagem não aceitou a idéia, alegando que haveria gastos excessivos de combustível. Ele era a favor da construção de dois altos fornos; um para fusão e outro para o refino. Assim, o gasto com o combustível seria menor e o rendimento maior. As opiniões se dividiram, porém a maioria ficou ao lado de Varnhagem. O Conde de Linhares, informado sobre as divergências, aparentemente não tomou partido. Chamou Varnhagem à Corte alegando necessitar de seus serviços em Minas, uma maneira sutil de tirá-lo do projeto.

Hedberg teve seus fornilhos concluídos e, em 1813, dois deles entravam em funcionamento. Porém, após oito dias os técnicos suecos entraram em greve, alegando que o tempo determinado no contrato havia se esgotado. O fato obrigou o Governo de São Paulo a

\footnotetext{
${ }^{4}$ Primeiro nome da Fábrica de Ferro de Ipanema.
} 
intervir e, para continuar com o projeto, prorrogou o acordo por mais seis meses, porém em condições mais onerosas para o tesouro.

Em 21 de fevereiro de 1815, o major Varnhagem tomava posse como diretor da Real Fábrica de Ipanema. Seguiu com seus primeiros planos, determinando a construção de altos fornos, (Carvalho Franco, 1964:14).

Em 21 de fevereiro de 1815, passa a tomar conta da Real Fábrica do Ypanema, Frederico Warnhagem. Em 23 de maio de 1822, por ocasião da "Bernarda de Francisco Ignácio", é nomeado o sueco Lourenço Hultgren para o cargo de feitor e mestre de fundição e refino. O alemão Neimands é nomeado para feitor e mestre de fornos de revérbero e obras modeladas. Em 8 de janeiro de 1835, assume a direção da fábrica o Major de Engenheiros João Bloem, nascido em Elberfeld, na Renânia. Após a sua posse, Bloem vai à Alemanha e, em 1838, traz uma leva de 227 recrutados. Muitos deles trouxeram suas famílias. Entre eles o mestre fundidor Frederico Holtz. Frederico permaneceu na fábrica até o tempo do Cel. Mursa, com quem, aliás, segundo Jesuíno Felicíssimo, viajou à Europa em 1873, para adquirir novos equipamentos e contratar novos operários. Mas, fato singular, após um ano de trabalho em Ipanema, a maioria dos novos contratados por Bloem, já se tinham retirado dali. Arranjando ocupações, deles permanecendo apenas 18.

Quando Spix e Martius visitaram o local, a fábrica estava numa fase de transição. O trabalho dos suecos se mostrara moroso e ineficiente, de forma que novos técnicos, desta vez alemães, foram chamados. O engenheiro Friedrich Varnhagen ergueu dois altos-fornos geminados e deu início a uma produção que chegaria a três toneladas por dia. Desses tempos de pioneirismo restam ainda, além dos altos-fornos, a primeira represa do Brasil, construída para aproveitar as águas do rio Ipanema, e a Casa da Administração, em estilo colonial. Já a Casa das Armas Brancas testemunha outro período de apogeu: em 1865 a fábrica foi remodelada para suprir a demanda de baionetas, sabres, espadas e pontas de lança da Guerra do Paraguai. A partir de 1875 uma pequena estação ferroviária vem facilitar o escoamento da produção de moendas de cana, engenhos de serraria e rodas e eixos de vagões. Até o gradil do Jardim da Luz, em São Paulo, com 166 metros de extensão, veio de lá. A fábrica foi fechada em 1895, classificada como "um monstrengo técnico mal situado, sem força motora, sem matas". 
Figura 1 - Vista parcial da Fábrica de Ferro de Ipanema. S/d.

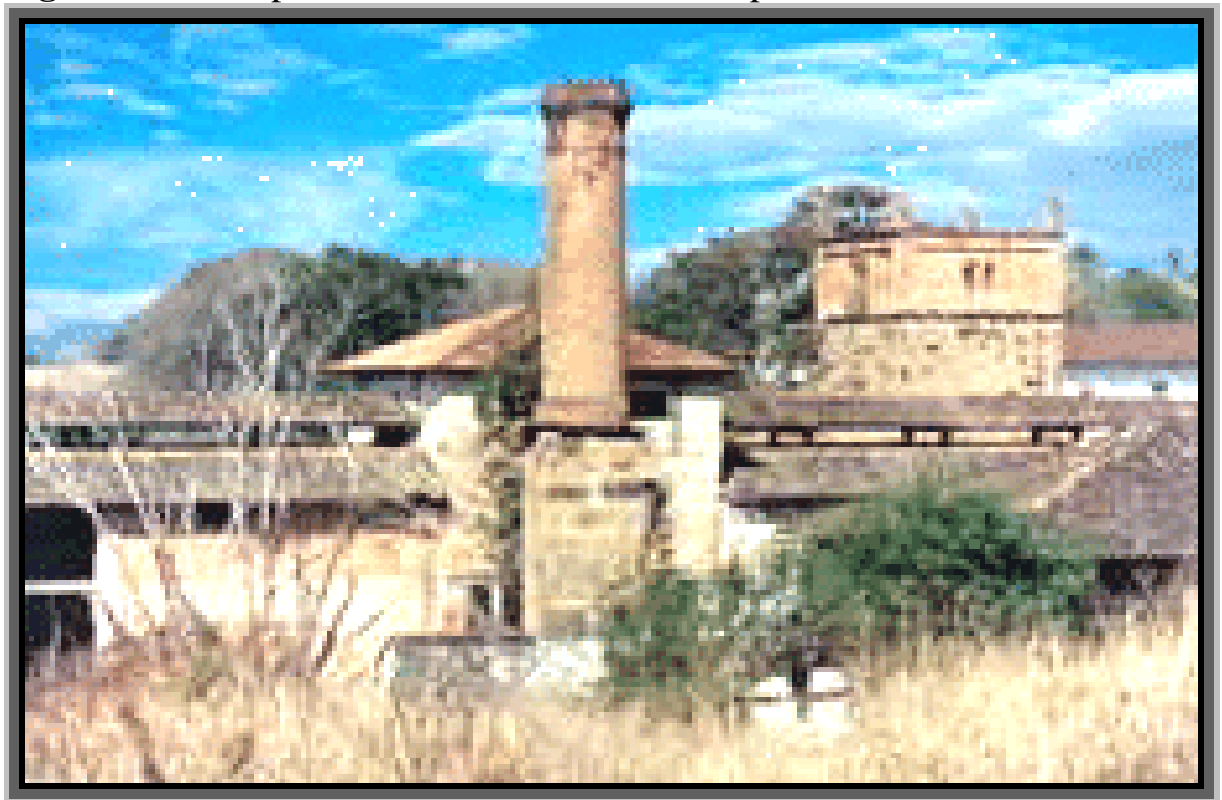

Fonte: Acervo do Instituto de Pesquisas e Estudos Morro de Araçoiaba.

Figura 2 - Vista lateral da Fábrica de Ferro de Ipanema. S/d.

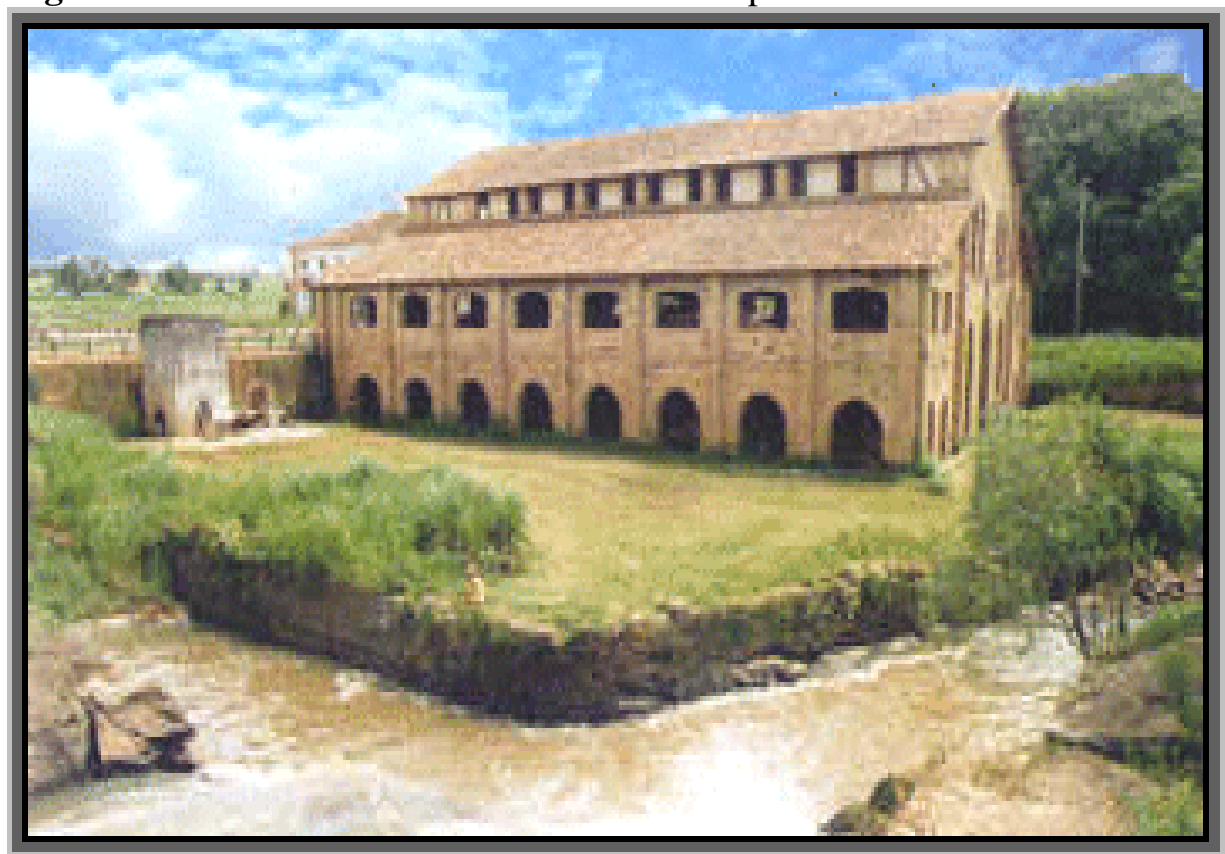

Fonte: Acervo do Instituto de Pesquisas e Estudos Morro de Araçoiaba. 
Figura 3 - Vista parcial da frente da Casa da Guarda da Fábrica de Ferro de Ipanema. S/d.

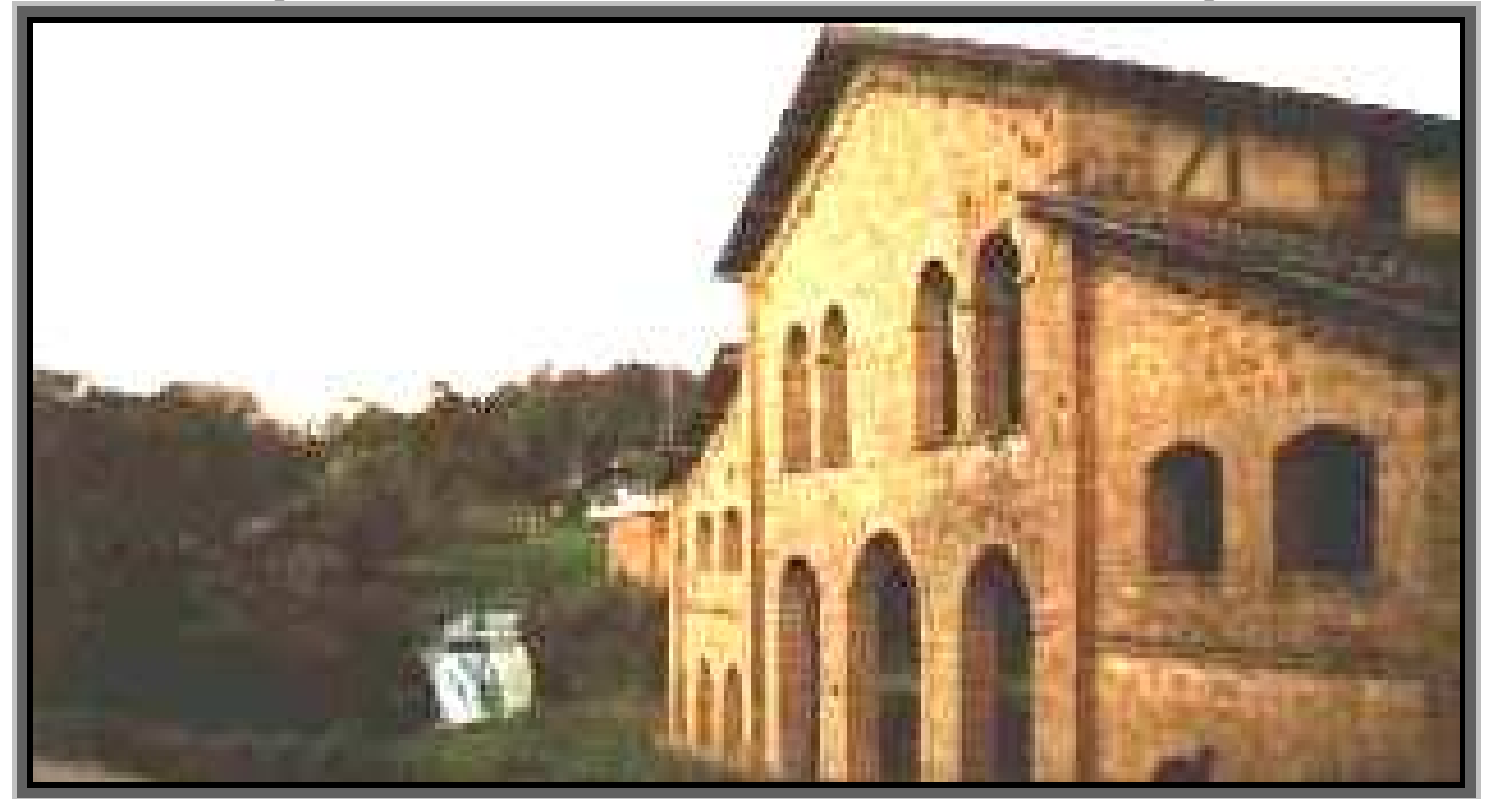

Fonte: Acervo do Instituto de Pesquisas e Estudos Morro de Araçoiaba.

Em 1929 teve início uma experiência para o aproveitamento da apatita, outro minério existente na Montanha de Araçoiaba. Mais tarde, com instalações entregues à firma particular, a produção de superfosfato prosseguiu até 1944. Mas já em 1937, o acervo e área ocupada pela antiga Fábrica de Ferro foram transferidos ao Ministério da agricultura que, em 1947, instalou ali a Estação Experimental do Trigo, onde se seguiram experimentos genéticos de sementes de cereais ${ }^{5}$.

\section{A música como fator integrador racial}

As minas de ferro do Ipanema são um referencial cultural para nossa região, pois foram os suecos e alemães responsáveis por trazerem da Europa instrumentos, conhecimento musical e o gosto pela música que foram passados aos seus descendentes e principalmente aos escravos da região, determinando mudanças no panorama histórico e sociocultural, onde a música passa a ser um fator de suma importância, pois a grande característica da difusão cultural é ela ser o primeiro processo de integração e civilizador de um povo. Pode-se em parte, atribuir a ela um fato histórico particular: Antes da abolição da escravatura, os escravos tatuianos estavam todos alforriados, isto é libertos.

\footnotetext{
${ }^{5}$ www.educatur.hpg.ig.com.br/ipanema.htm. Arquivo consultado em 2001.
} 
A essência do fenômeno não se manifesta nas coisas em si, mas em suas relações e em Tatuí, a música deu vida a um contexto cultural fundamentado numa metodologia da busca de excelência musical, onde a raça, a origem social e econômica do músico era o que menos importava como podemos notar na foto abaixo, a presença majoritária de pretos e pardos numa das corporações musicais de Tatuí no início do século XX.

Figura 4 - Corporação musical de Tatuí. S/d.

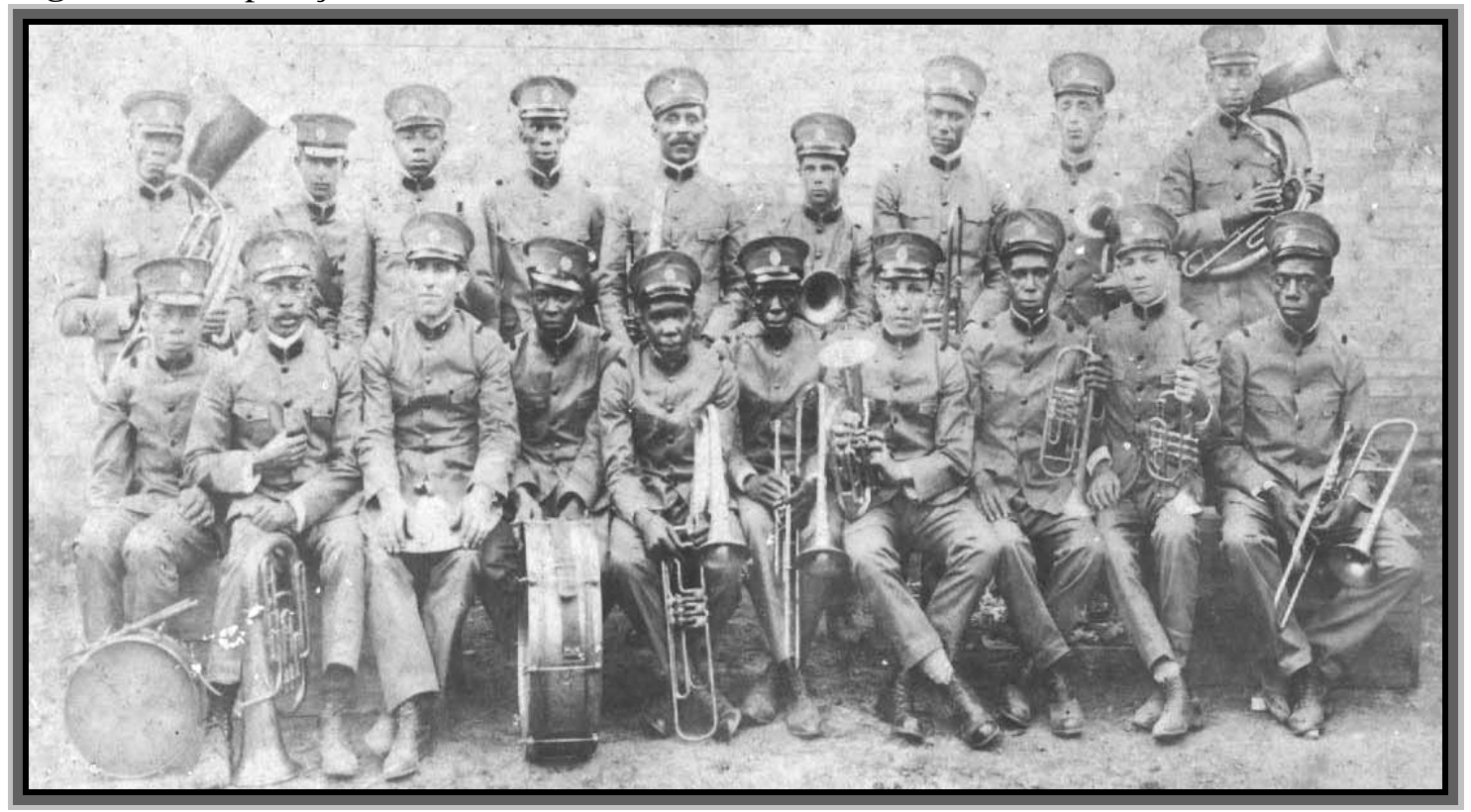

Fonte: Acervo de Marcelo A. Afonso.

Figura 5 - Corporação "União Operária” de Tatuí. S/d.

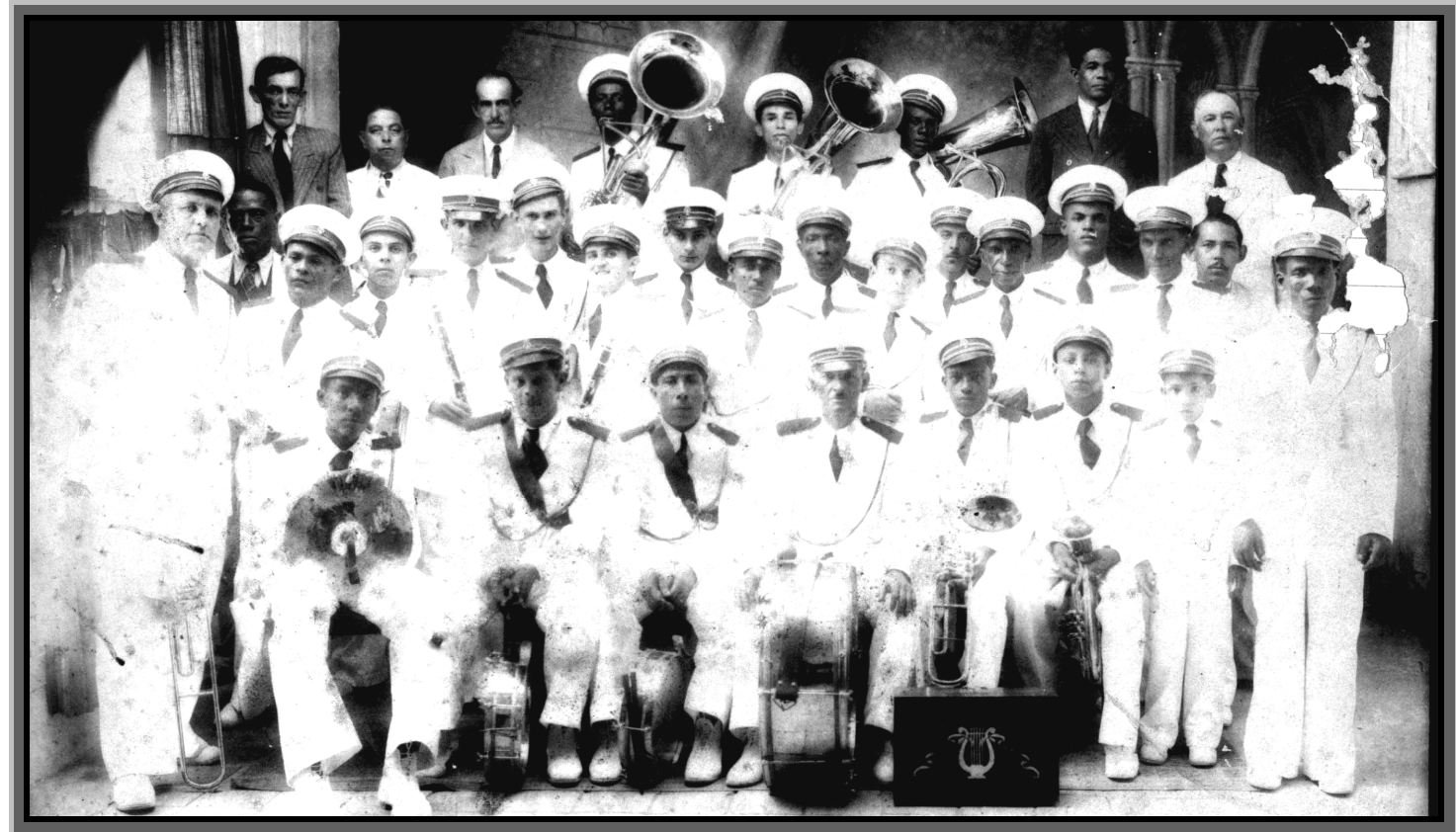

Fonte: Acervo do Museu de Tatuí. 
A música percorreu a antiga estrada do Vai e Vem, (que hoje não existe mais), que fazia a ligação entre Tatuí - Fábrica do Ipanema - Sorocaba, que teve papel importantíssimo para a cultura de Tatuí, pois, por ordem régia, os moradores da Fábrica do Ipanema eram proibidos de cortarem madeira e utilizarem as terras na área em que se achava instalada a "Real Fábrica de Ferro de São João de Ipanema".

Foi através desse fato, que provocou a vinda dos moradores ao sítio de "Tatuhu", que a música se instalou definitivamente na sociedade local, onde surgem os primeiros maestros de Banda (palavra de origem germânica) e os primeiros "professores" de música, isto é, pessoas sem formação acadêmica, mas com conhecimento e talento musical.

A banda de música sempre foi, paralelamente ao seu valor como forma de expressão cultural permanente, tanto nos grandes centros quanto nas pequenas cidades do país, um terreno fecundo para a formação de instrumentistas, de que se têm nutrido as orquestras e outros grupos musicais. A cidade de Tatuí chegou a ter três bandas musicais simultaneamente, tais como a Corporação "União Operária", Banda Santo Antonio e Banda Santa Cruz que mantinham certa "rivalidade" musical entre si.

Figura 6 - Banda de Tatuí do início do século XX. S/d.

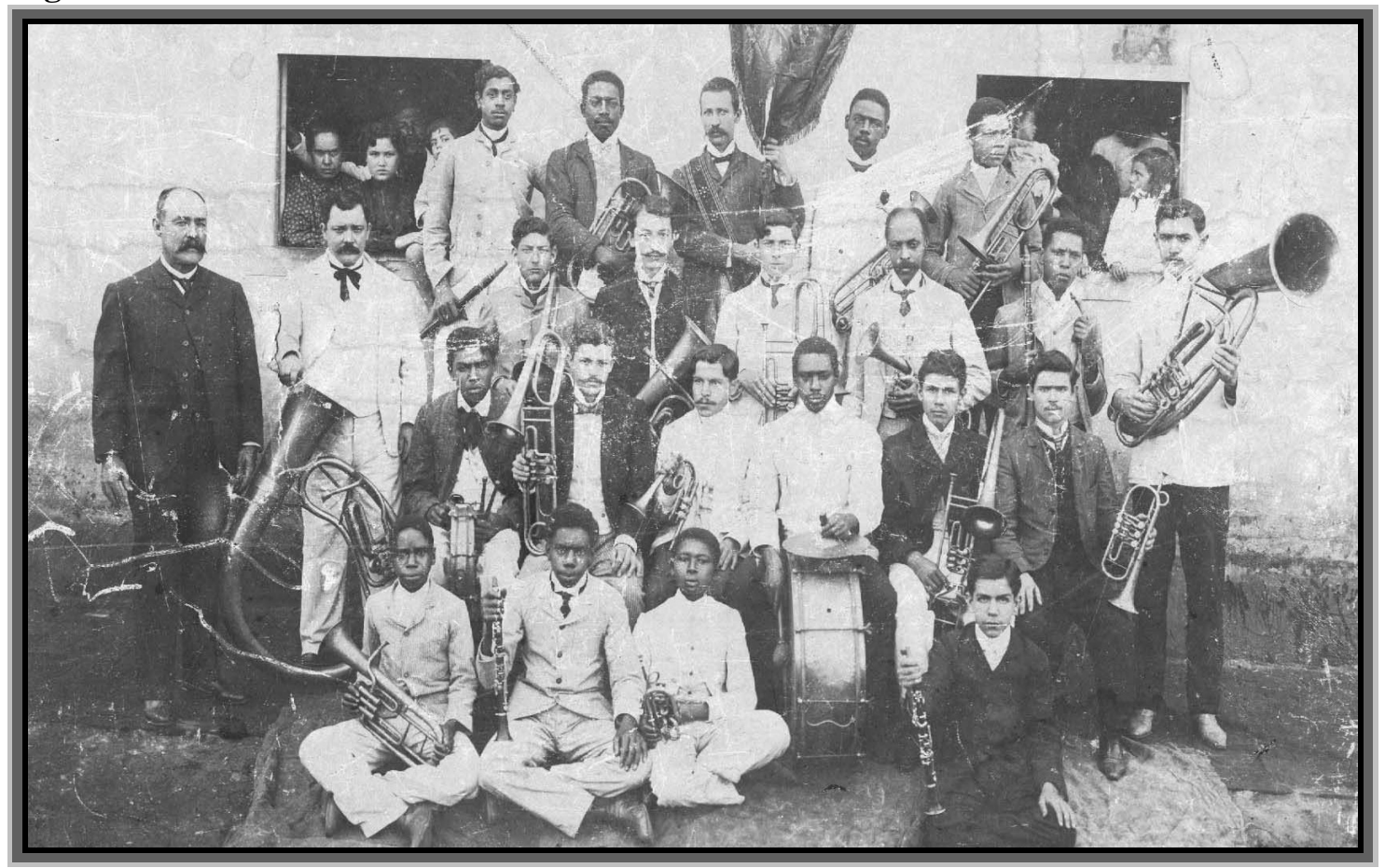

Fonte: Acervo de Marcelo Ap. Afonso. 
Segundo o Jornal Integração (1999), a Sociedade Musical "Santa Cruz", considerada uma das mais antigas do país e mais conhecida como "Banda Santa Cruz", tem seu nome ligado às festas de Santa Cruz que teve sua origem a partir de 1847, tendo como seu fundador o Sr. Mathias Frankler.

Devido à falta de documentos a data de fundação é considerada como sendo 28 de maio de 1887, por Francisco Paschoal Bailão, Antonio de Godoy Moreira, Deolindo José da Rocha e Alexandre Machado.

Participou de eventos memoráveis, como o da madrugada de 13 de maio de 1888 , data da Abolição da Escravatura, quando saiu nas ruas de Tatuí, despertando a pequena população de três mil habitantes para uma nova era.

Durante todos estes anos, a corporação esteve presente nas mais diversas comemorações da cidade (leilões, inauguração de estradas, posse de prefeitos, visitas de autoridades) e representou Tatuí em eventos por todo o Estado de São Paulo e Brasil. Em 1975, esteve na Convenção Mundial de Turismo, no Rio de Janeiro, ao lado do famoso "Cordão dos Bichos". Entre os músicos que tiveram a honra de reger a Banda Santa Cruz, destaca-se o maestro José Coelho de Almeida, (que foi diretor do Conservatório de Tatuí), Marcelo Aparecido Afonso, (professor do Conservatório de Tatuí e neto de Praxedes Campos, respeitado músico do início do séculoXX), e atualmente, Sérgio Gonçalves de Oliveira, (professor do Conservatório de Tatuí), dentre outros ${ }^{6}$.

Figura 7 - Primeira fotografia da "Banda Santa Cruz", tirada em 1888.

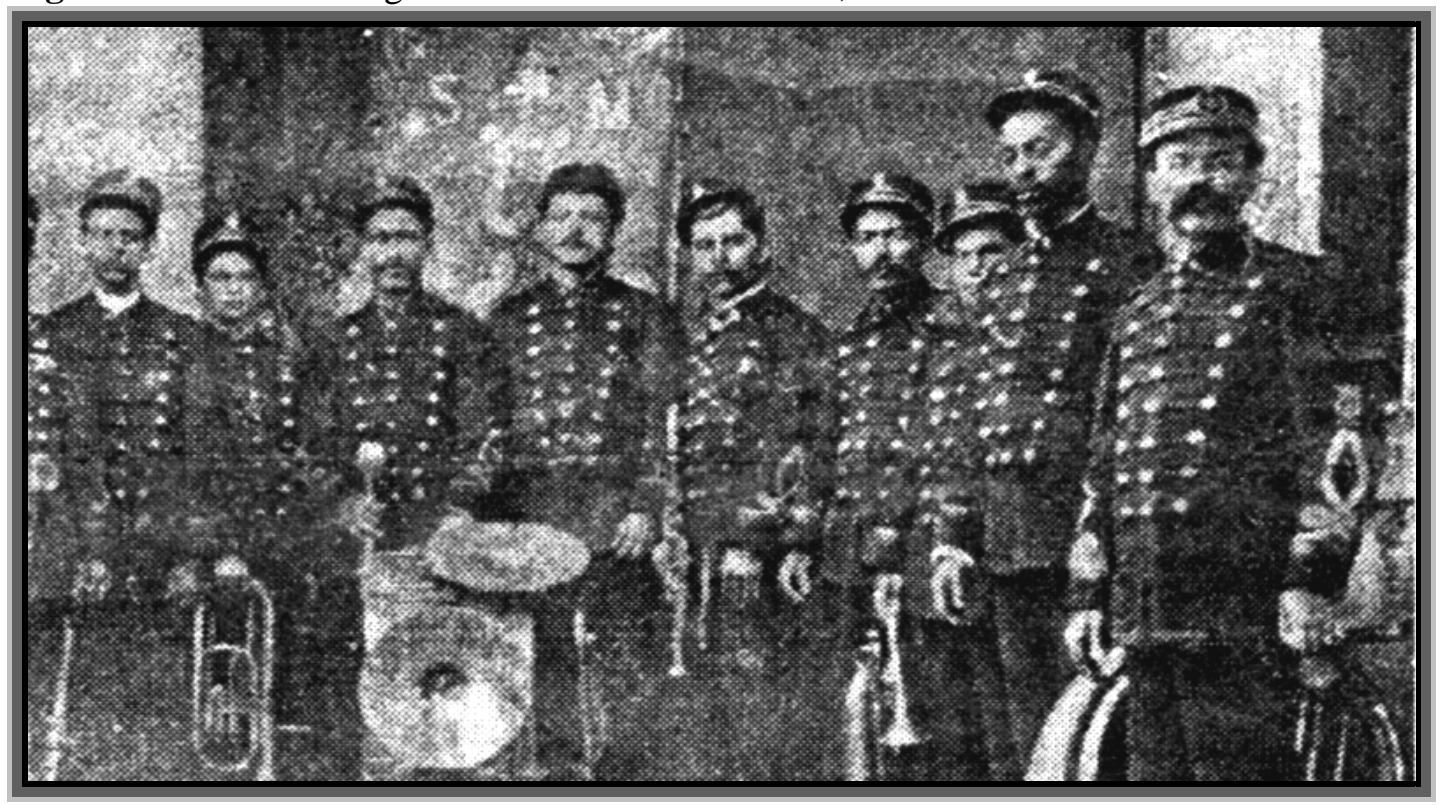

Fonte: Acervo Marcelo Ap. Afonso.

\footnotetext{
${ }^{6}$ Jornal Integração, Tatuí, 07 de março de 1999, pág.05.
} 
Figura 8 - Corporação Musical "Santa Cruz", início do século XX. Na segunda fila, o quinto músico, da esquerda para a direita, Praxedes de Campos, avô de Marcelo Ap. Afonso. S/d.

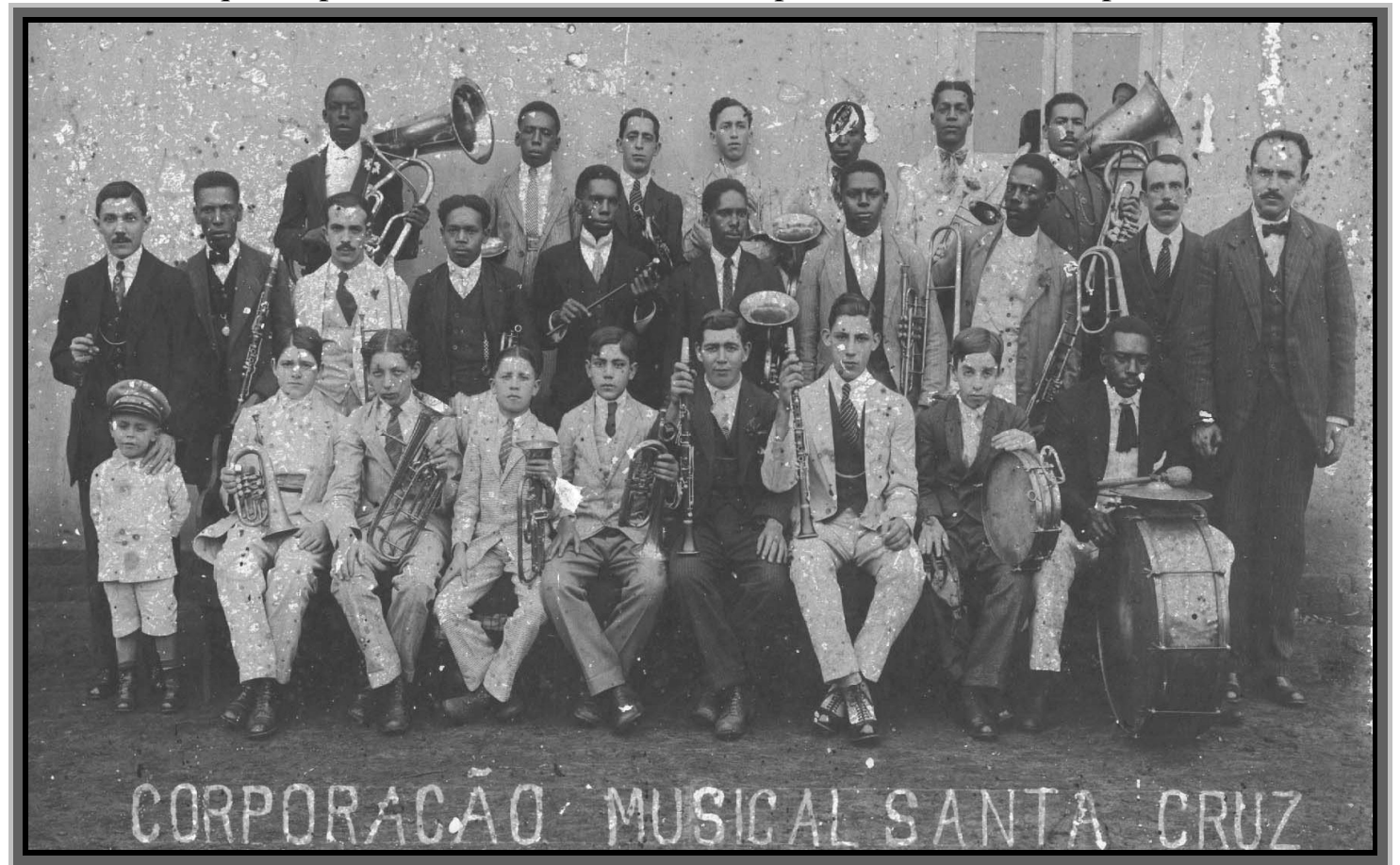

Fonte: Acervo de Marcelo Ap. Afonso.

Figura 9 - Banda "Santa Cruz", 1922.

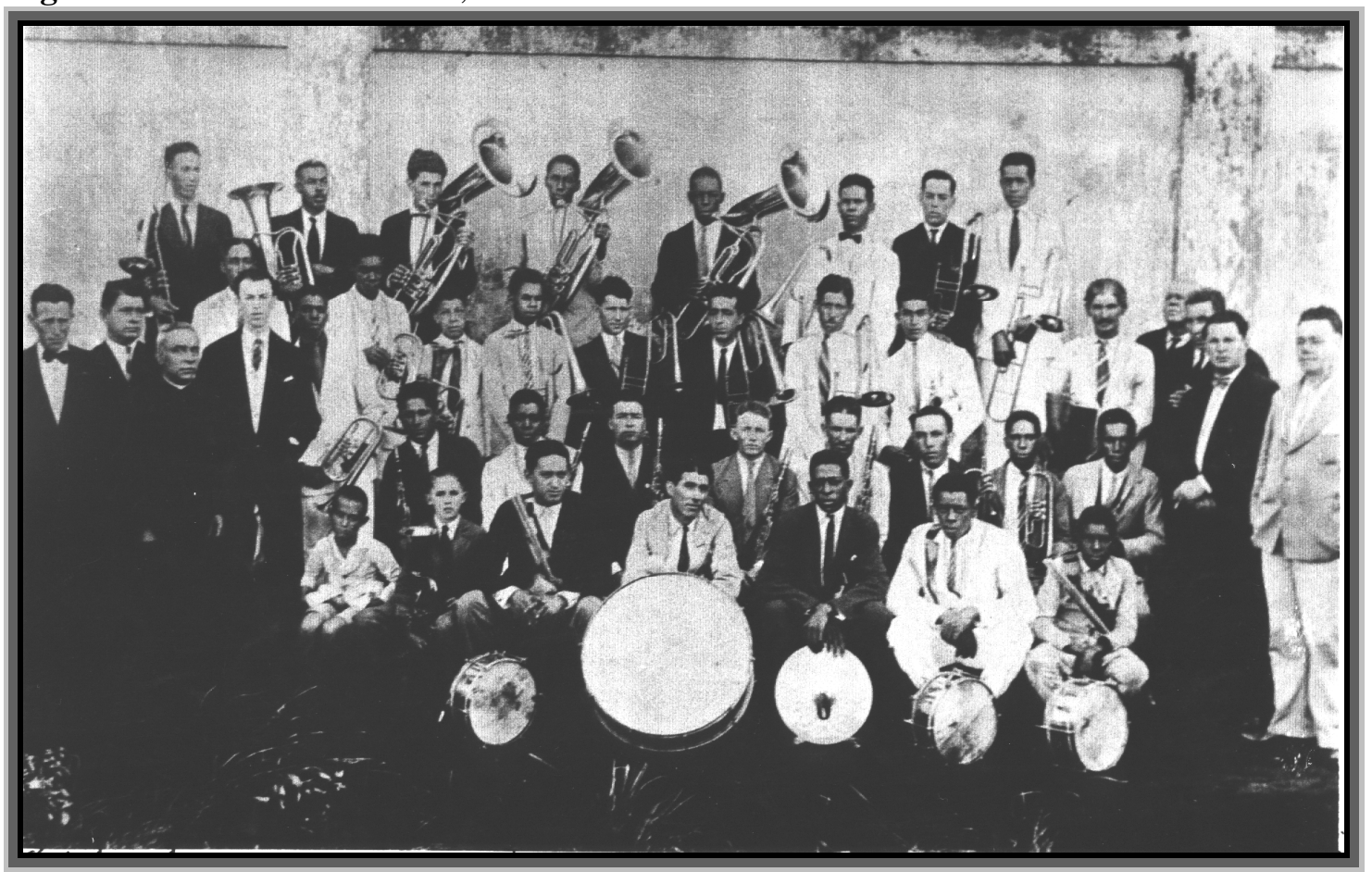

Fonte: Acervo de Marcelo Ap. Afonso. 
Figura 10 - Banda “Santa Cruz", 1930.

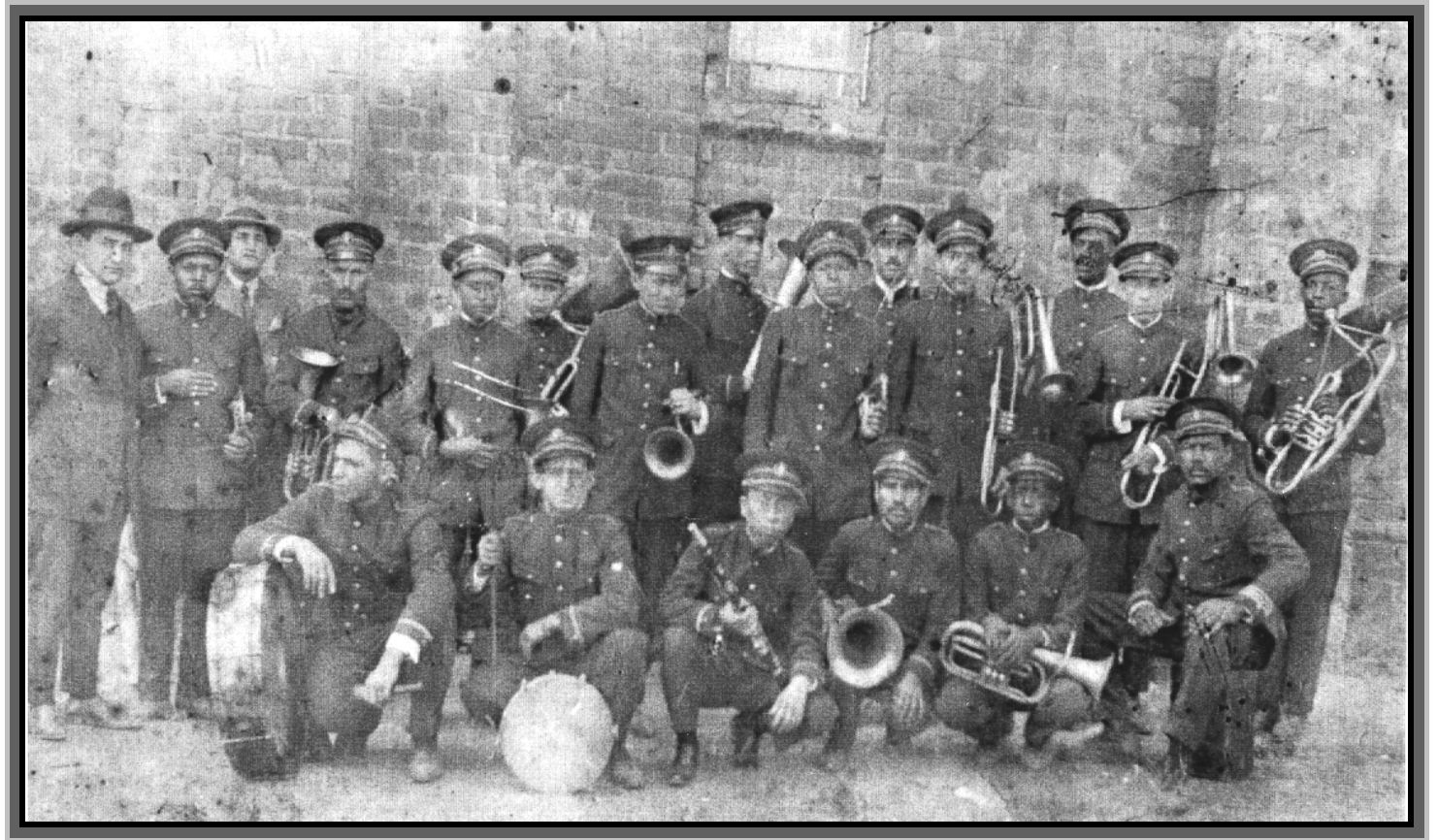

Fonte: Acervo de Marcelo Ap. Afonso.

Figura 11-Banda "São Vicente de Paula", 1940.

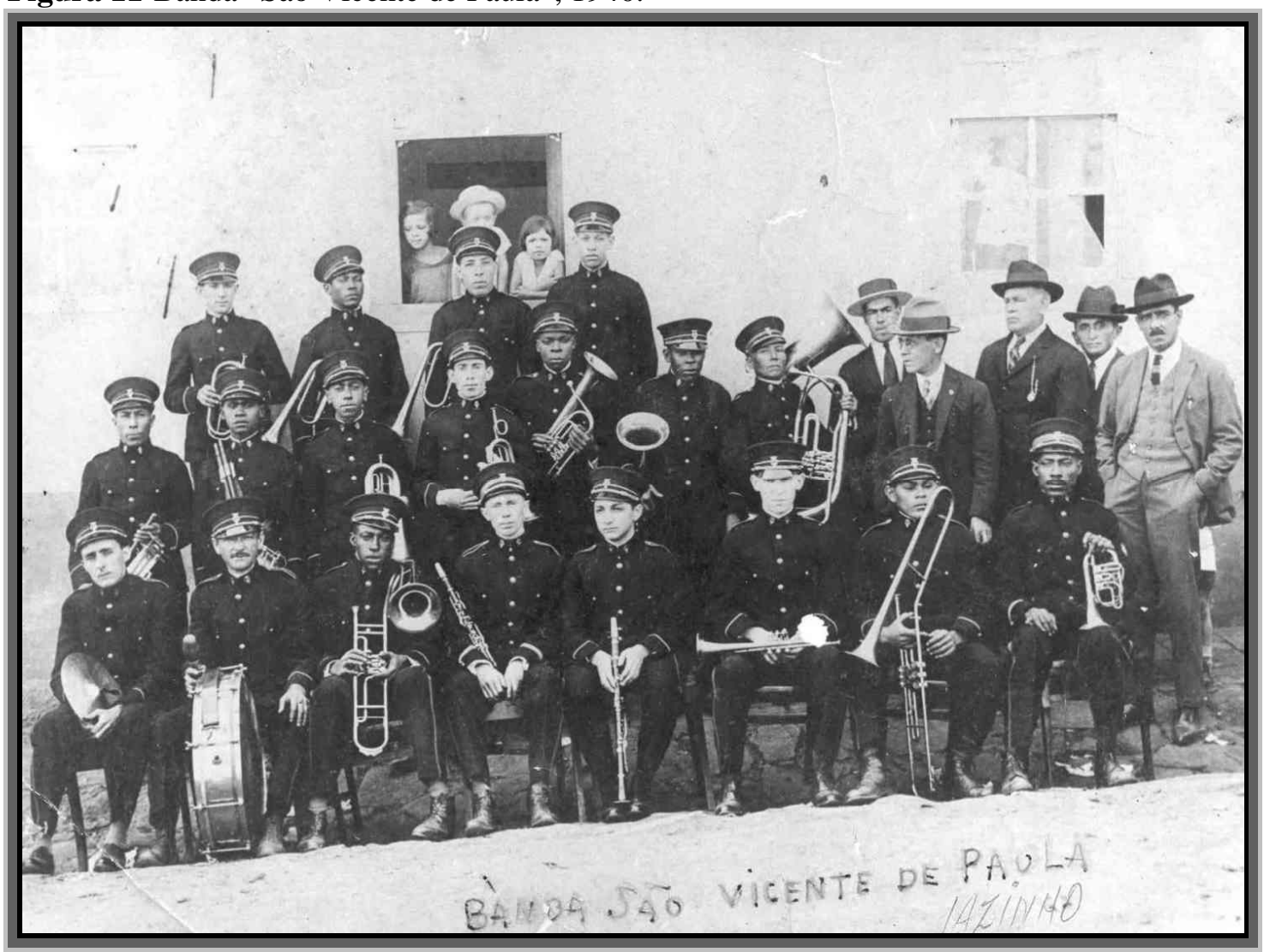

Fonte: Acervo do Museu de Tatuí. 


\section{O panorama social e organizacional de uma época}

O grande desenvolvimento musical de Tatuí, onde havia uma idealização artística e sua realização por uma parcela da população, tomou impulso no início do século XX, mais precisamente na década de 1920, raridade para a época e realidade brasileira, quando tínhamos uma classe média tímida e provinciana, elite governante completamente alheia a questões políticas e culturais, população rural miserável e ex - escravos marginalizados. Porém, como a cultura musical gera um processo aglutinador na sociedade, podemos notar na foto abaixo, de uma das organizações musicais de Tatuí, a participação de homens, mulheres, negros e crianças, demonstrando que a música pode dissolver separações e exclusões de gêneros raciais.

Figura 12 - Corporação Musical "União Operária”, 1935.

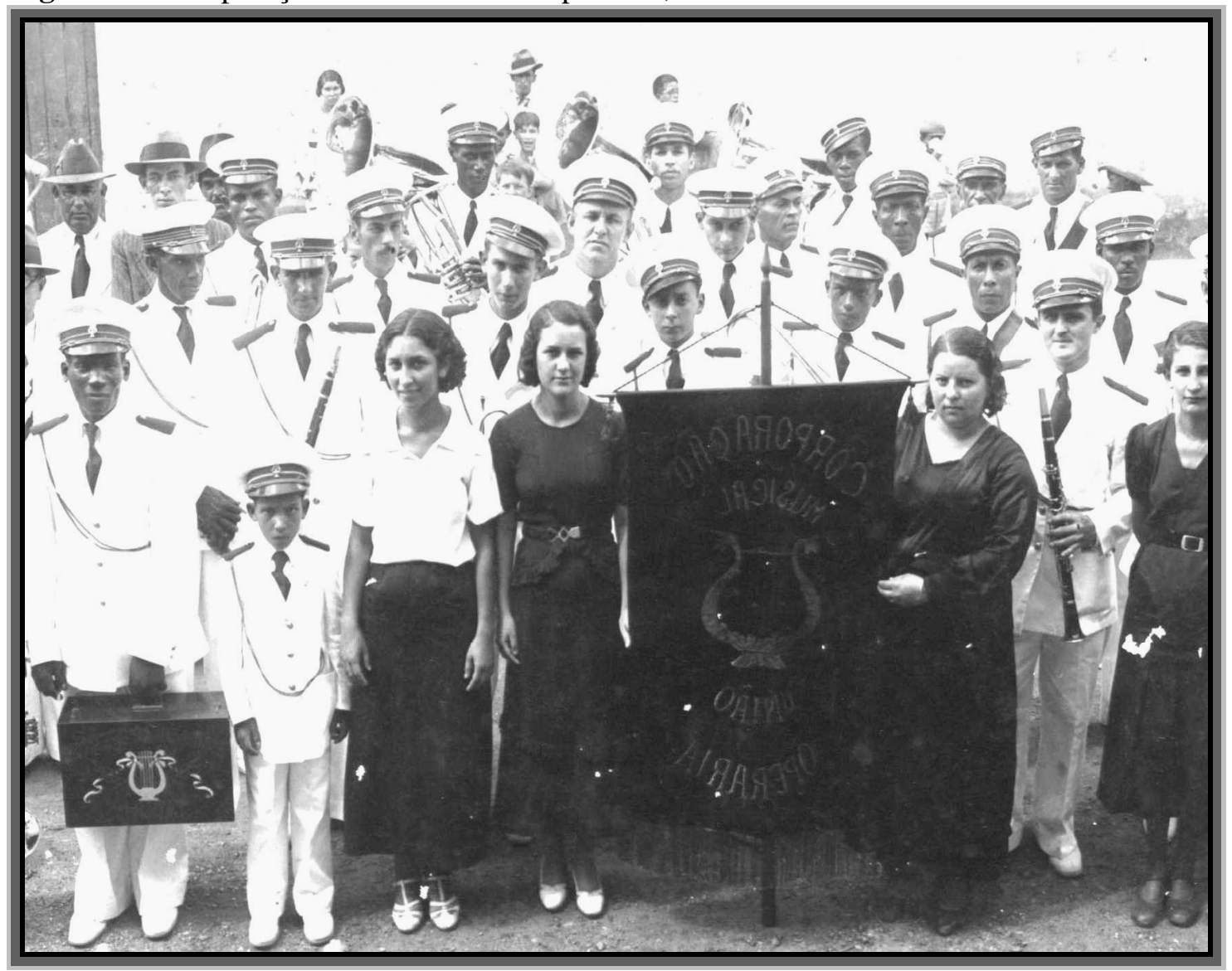

Fonte: Acervo do Museu de Tatuí 
Nesse panorama histórico e social é que nos deparamos com as transformações culturais ocorridas em Tatuí, pois a um movimento artístico que visa à ampliação do conhecimento, podemos chamar de cultura. Cultura que modificou para sempre os caminhos da cidade e seus habitantes, passando a fazer parte do modo de "viver" de Tatuí, como na foto abaixo de um conjunto carnavalesco de 1927 e outro de 1939.

Figura 13 - Carnaval de 1927.

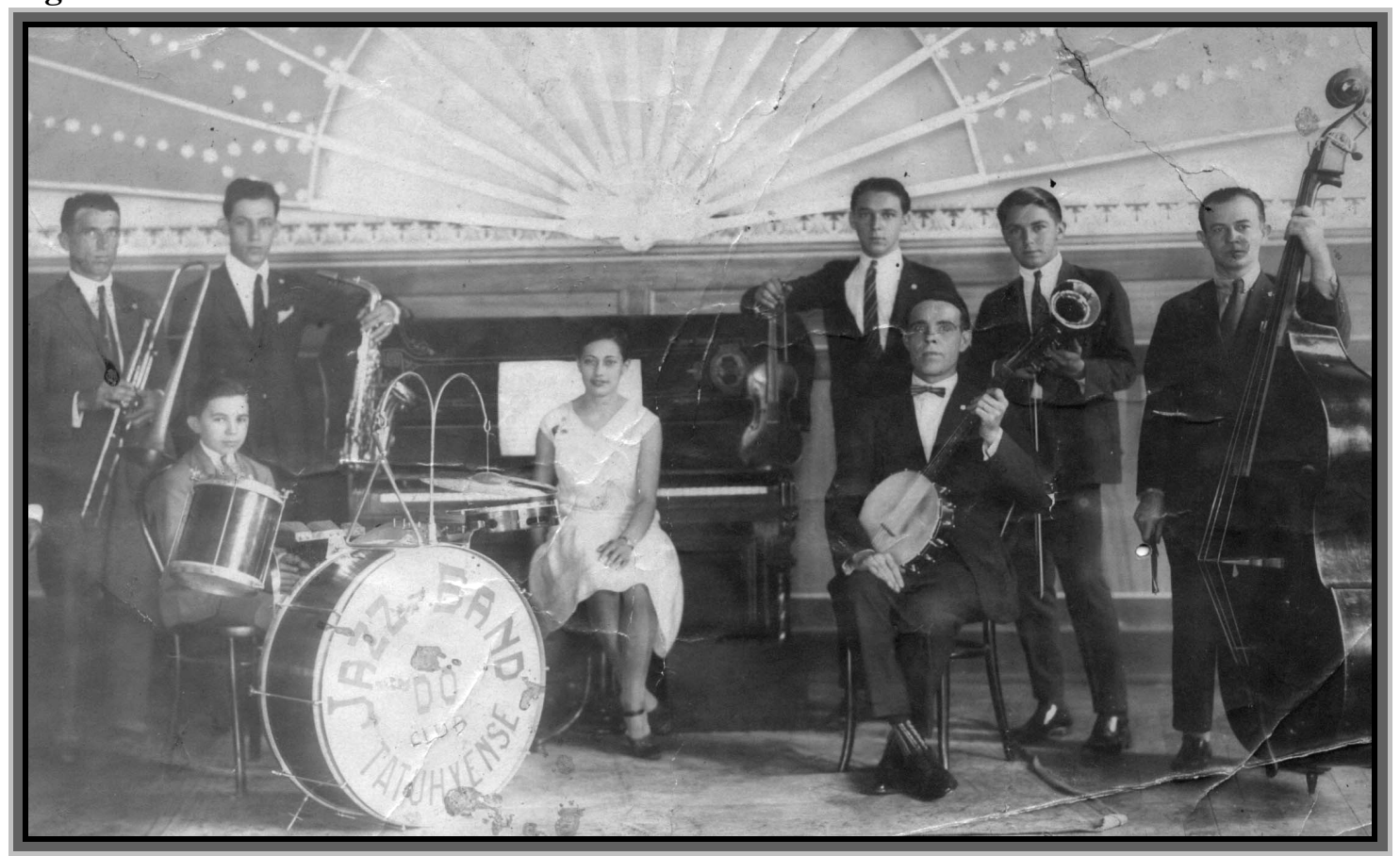

Fonte: Acervo do Museu de Tatuí.

Figura 14 - Carnaval de 1939, Conjunto "Jazz União Operária” Tatuí.

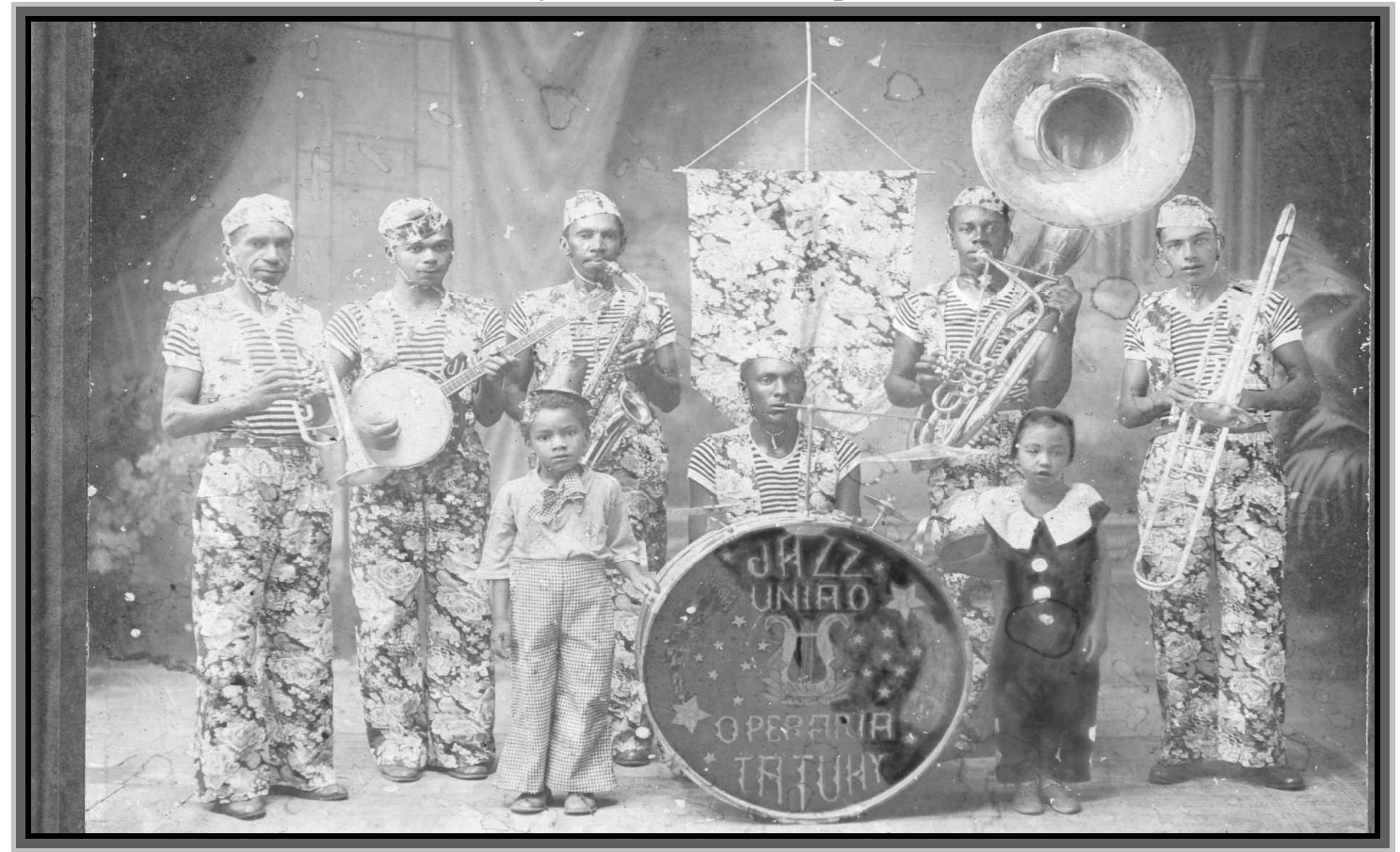

Fonte: Acervo de Marcelo Ap. Afonso. 
Na década de 1930, com a criação do "4 Ginásio Estadual - Barão de Suruí", vem da cidade de Capivarí o professor Nassif Farat, para lecionar música no ginásio de Tatuí. Músico e compositor de excelente formação, logo que chegou à cidade, organizou orfeão escolar, apresentações de operetas, dando oportunidade de a cidade conhecer grandes compositores de músicas litúrgicas, inclusive a sua própria, pois Farat era um compositor essencialmente sacro e é com ele que se estabilizaria o trabalho de canto coral e canto orfeônico.

Escrevia nos jornais da cidade sobre música e formas musicais, estimulando de tal forma o gosto musical que acabou organizando juntamente com outros musicistas da cidade um pequeno conjunto, que poderia ser denominado como camerístico de tão pequeno que era. O conjunto era composto por Otávio "Bimbo" Azevedo, (violino e conhecido compositor de valsas, dentre elas a mais famosa é "Dirce"), Hortênsia Pascale, (piano), Joaquim "Juca" Fonseca, (contrabaixo), João Del Fiol, (violino), "Zico" Lázaro Bertrami, (violino), Humberto Bertrami, (clarineta), que se apresentavam durante as solenidades e festas da cidade sempre recebendo elogios pela performance do grupo. Infelizmente Farat faleceu muito moço e a organização do conjunto passou para as mãos de João Del Fiol.

Personalidade ativa e organizativa na cidade, João Del Fiol desenvolveu a idealização do Conservatório de Tatuí, como encarregado do conjunto, que ficou com a seguinte formação: primeiros violinos, Bimbo e seus alunos, (José Carlos Molitor e Orlando Lisboa de Almeida); segundos violinos, João Del Fiol e seus alunos, (José dos Santos, Jonas Simões de Almeida, Eudes Machado e Mateus Jacob Hessel); os violoncelistas Semeão Cassemiro e Décio Lourenção; Juca Fonseca no contrabaixo e Hortênsia Pascale no piano.

A música era tão popular em Tatuí, que houve necessidade de que os músicos locais se aperfeiçoassem não só nas peças de bandas, (que já figuravam como tradição da cidade), mas também nas obras de compositores estrangeiros, principalmente franceses e italianos (que estavam em moda), tanto quanto em arranjos de músicas conhecidas na época. Assim, os músicos da cidade passaram a se reunir para preparar e ensaiar as partituras e arranjos, superando o aspecto amadorístico. Pode-se notar que o artista não tem consciência imediata que a política cultural está interna na própria produção cultural, e que esse processo, na transformação de uma sociedade, é irreversível. Porém, nosso questionamento é: o que é inovador nessa organização? 


\section{A idealização do Conservatório de Tatuí}

Durante os anos de 1950, o Brasil vivia um clima de esperança e desenvolvimento, em que passamos de um país essencialmente agrícola para um país industrial. A ideologia nacionalista propunha a superação dos problemas sociais e do atraso econômico e cultural. Desse ponto de vista, a ausência de um Conservatório Dramático oficializado no Estado de São Paulo, era considerado como um potencial "atraso" cultural para o Estado mais rico do país.

Uma sociedade é julgada pela história, entre outras coisas, de acordo com sua contribuição para a cultura de seu país. $\mathrm{O}$ fato de ter a cultura, de alguma forma, se tornado um departamento da política não deve obscurecer os esforços dos pioneiros que abriram novos caminhos para organizações culturais, fato que ocorreu em Tatuí.

Figura 15 - Vista aérea do centro da cidade na década de 1950.

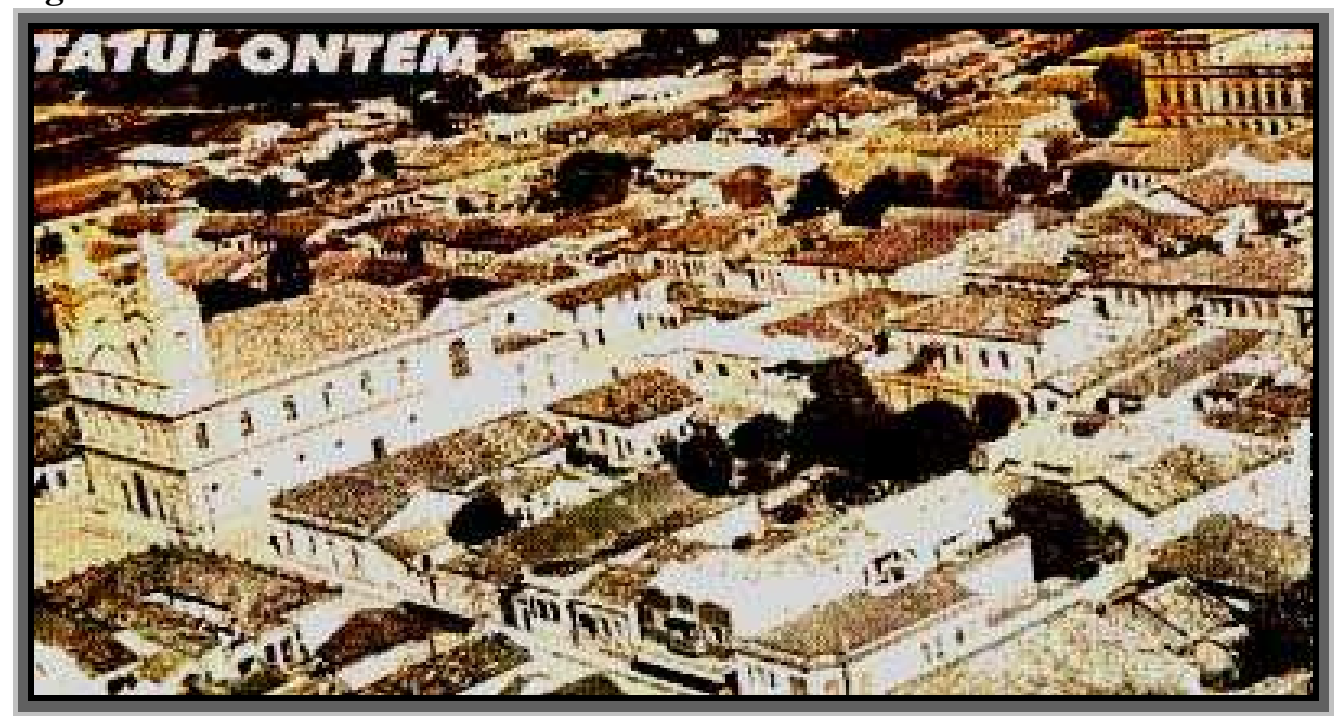

Fonte: Acervo próprio.

Conforme relato do entrevistado professor José dos Santos, na década de 1950, em visita à Tatuí a convite do então vice-prefeito Dr. Aniz Boneder, médico de grande influência nos meios sociais e políticos da cidade, o então deputado Estadual, Narciso Pierone foi o convidado de honra da festa de formatura dos alunos da Escola Estadual "Sales Gomes", mais conhecida como Escola Industrial, no Clube Tatuiense.

O deputado e outros convidados influentes como Maurício Loureiro Gama e Nelson Marcondes do Amaral, ouviram a apresentação do conjunto de cordas e piano, composto por 
músicos da cidade, liderados por João Del Fiol, descrito anteriormente. De acordo com os entrevistados que foram testemunhas oculares, o objetivo do vice-prefeito, Dr. Aniz Boneder, era impressionar o deputado com a qualidade musical do conjunto, pois há muito tempo a cidade, acalentava a idéia de se criar um conservatório e de preferência com a ajuda do Estado. Naquele tempo, (as transformações históricas da década de 1950 implicaram na utilização pelos ideólogos do Estado Novo na indústria cultural), em Tatuí, reinava um clima adequado e o momento era favorável, pois, a cidade tinha o principal, professores de música que davam aulas em suas casas para alunos da cidade e região.

A fama de Tatuí como cidade da boa música e de bons músicos já estava consolidada e já existia um público que demonstrava gosto pela música erudita e que sempre recebia grupos musicais de outras cidades, entre eles o quarteto Municipal da cidade de São Paulo, somente faltava o apoio político.

João Del Fiol, músico da cidade, que com o fim do cinema mudo começara a dar aulas de violino e violoncelo em sua casa, se apresentou com o conjunto na festa, tocando peças de Mozart, Händel e outros compositores, ao final da apresentação do conjunto, João Del Fiol, executou a peça Ária da Quarta Corda de Bach, provando que realmente a música intui e transporta a diferentes estados de alma, pois o deputado Narciso Pierone e os demais convidados ficaram extremamente impressionados com a qualidade e performance do grupo.

Terminada a apresentação, o vice-prefeito Dr. Aniz Boneder, aproveitando-se da oportunidade acompanhou o deputado até o "Hotel Del Fiol", (pertencente à família Del Fiol), em que ele estava hospedado, juntamente com os políticos da cidade, para se reunirem com seu visitante e tratarem de "negócios".

Durante a conversa, o deputado perguntou o que poderia ser feito por Tatuí, devido à boa impressão que tivera da apresentação musical durante a formatura. Del Fiol, que tinha executado a peça que impressionara o deputado estava entre os presentes e, pensando em termos modestos, falou do seu desejo de que os conjuntos da cidade recebessem o apoio do governo na compra de métodos e arranjos musicais e que, se possível, fosse criada uma escola de música para a cidade. Era do conhecimento de todos o conceito musical da cidade e o interesse que as pessoas tinham pela música. Além disso, Del Fiol, tinha por volta de 20 alunos que se iniciavam na música, tendo aulas em sua casa, dentre eles Mateus Jacob Hessel, que desde a criação até década de noventa, tocava nos conjuntos musicais do Conservatório de Tatuí, mesmo nunca tendo sido aluno da escola.

Dessa conversa informal, nasceu a idéia de se criar um conservatório em Tatuí, pois o deputado Narciso Pierone considerou mesmo que a cidade merecia uma escola de música. A 
minuta do projeto foi elaborada ali mesmo, em papel de rascunho (papel de embrulho do hotel), no qual todos os presentes deram palpites, e que seria apresentada na Assembléia de São Paulo. O próprio deputado (conhecido nos meios políticos como "dono da Assembléia"), levou a minuta a São Paulo, onde a Assembléia votou a favor devido às justificativas do deputado.

No ano de 1951, foi criada a Associação Cultural Pró Música, com o objetivo de desenvolver a área musical na cidade e por motivos políticos, pois durante a campanha eleitoral, o candidato a governador Lucas Nogueira Garcez se comprometeu com os políticos da cidade, caso fosse eleito, com a instalação de um Conservatório Musical na cidade.

Depois de eleito, o governador Lucas Nogueira Garcez sancionou, convertendo na lei 997 em 13 de abril de 1951 a criação do Conservatório Dramático e Musical de Tatuí.

No jornal, O Progresso de Tatuí, edição extraordinária do dia 19 abril de 1951, saiu em primeira página com o título: "Um marco de excepcional grandeza na história de Tatuí $1^{7}$ ".

\section{A origem do nome do Conservatório de Tatuí}

Para melhor conhecimento, se faz necessário buscarmos as origens do nome Conservatório de Tatuí. Consta, pela primeira vez, o atual nome do Conservatório de Tatuí, na Ata da $5^{\text {a }}$ reunião extraordinária da Congregação do Conservatório de Tatuí, de 22 de novembro de 1957, anteriormente era denominado de Conservatório Dramático e Musical de Tatuí e pertencia a Secretaria de Estado dos Negócios do Governo.

A escolha do nome "Dr. Carlos de Campos", foi uma homenagem ao primeiro governador músico do estado de São Paulo.

Dr. Carlos de Campos, além de músico, autor de peças líricas como "A Bela Adormecida" e "Um Caso Singular", também atuou como estadista, jornalista, parlamentar e político. No jornal Correio Paulistano de quinta-feira, 28 de abril de 1927, é publicada matéria sobre o falecimento de Dr. Carlos de Campos, presidente do estado de São Paulo, com manifestações de pesar pelo acontecimento. A matéria jornalística diz o seguinte:

"Somente as individualidades que se integram na alma do próprio povo podem produzir, com sua morte, tão profundo abalo como causou em São Paulo e no resto do País, o passamento do Dr. Carlos de Campos, presidente do estado. O sentimento de luto nacional transformou-se numa comoção

\footnotetext{
${ }^{7}$ Anexo D, pág. 174.
} 
mais íntima, mais pessoal, integrando-se nesse luto todos os cidadãos deste estado que admiravam e amavam o ilustre extinto.Desde as primeiras horas do dia, esgotadas as edições matutinas dos jornais que traziam a infausta notícia, a cidade, que amanhecera em expectativa, tomaram aspecto de uma cidade atingida por uma enorme calamidade. Enorme massa popular rodeou o Palácio dos Campos Elísios, onde após tão longa agonia finara-se o supremo magistrado desta unidade da Federação. Em atitude reverente e dolorosa, a multidão aguardou que a camara ardente, onde foi deposto o corpo do grande estadista, fosse franqueada ao público.Pessoas de todas as classes sociais, desde os mais expressivos representantes da aristocracia paulista aos mais modestos, todos irmanados num modo de tocante sentimento, desfilaram diante da urna mortuária do Dr. Carlos de Campos para prestar-lhe a derradeira homenagem ${ }^{8}[\ldots] . "$

Em 6 de agosto de 1966, a Comissão Estadual de Filatelia, do Conselho Estadual de Cultura da Secretaria de Estado dos Negócios do Governo de São Paulo, emitiu um encarte filatélico sobre o estadista, parlamentar, jornalista, político e músico Dr. Carlos de Campos.

Figura 16- Carlos de Campos.

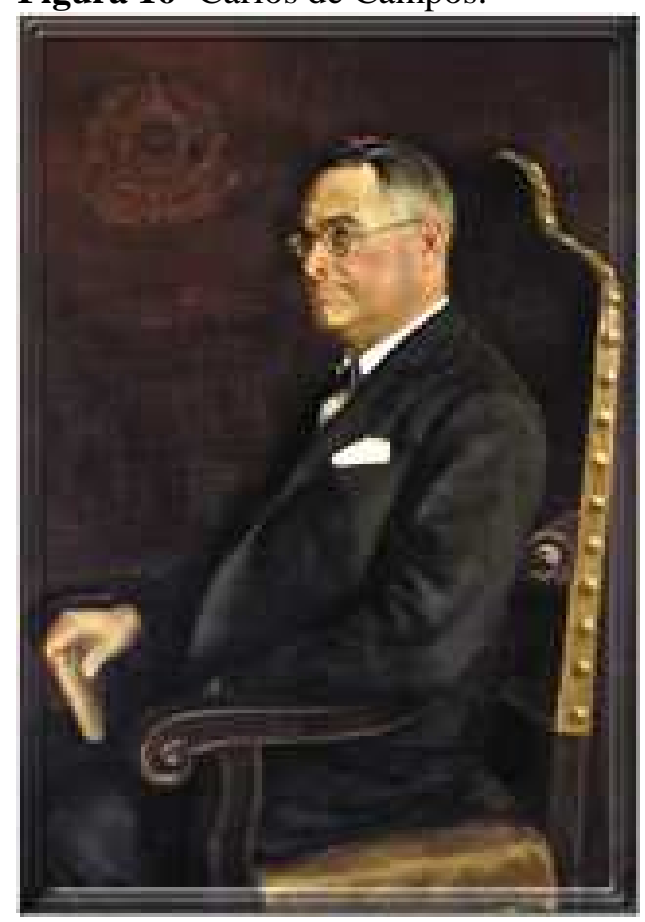

Fonte: Acervo - INTERNET.

\footnotetext{
${ }^{8}$ Jornal, Correio Paulistano, 28 de abril de 1927.
} 
"Lá onde a filosofia desampara e não consola, aí começa a arte".

(Schelling,1775-1854) 


\section{CAPÍTULO III}

\section{O PRIMEIRO DECÊNIO DO CONSERVATÓRIO DE TATUÍ \\ (1954-1964)}

\section{Recorte histórico}

A década de 1950 foi marcada no âmbito social, político e econômico, por uma série complexa de transformações que insinuavam o perfil de um momento de uma "nova modernidade", que forneceria um ambiente estimulante para o desenvolvimento de sugestões renovadoras nas artes. Não apenas a sociedade brasileira, mas todo o sistema internacional experimentou mudanças extraordinárias.

Uma nova arrancada tecnológica ocorreu no interior de um processo de remanejamento das relações internacionais que permitia a certos países tipicamente "subdesenvolvidos", como o Brasil, alcançarem, dentro de certos limites e em determinados setores, um razoável padrão de modernização industrial. O governo de Juscelino Kubstchek, cujo lema era "Cinqüenta anos em cinco", tinha como finalidade, com o seu "Programa de Metas", modernizar o Brasil dotando-o de indústrias de base e de bens de consumo.

É nesse período que a sociedade brasileira adquiria definitivamente sua feição urbana, movida pela ideologia do desenvolvimento e pela associação com capitais externos, com a instalação de um novo e sofisticado parque industrial. Pela primeira vez em sua história, as massas urbanas despontavam no cenário político e a cidade transformava-se, sem possibilidade de retorno, no centro decisório da vida nacional.

Essa configuração de um setor urbano-industrial moderno estreitava, como nunca, os laços entre o processo social interno e a dinâmica do sistema internacional. Uma área considerável da população passava a desfrutar de uma experiência social cada vez mais próxima a dos habitantes dos maiores centros urbanos internacionais. Diminuíam as distâncias e aumentava a sensibilidade para as conquistas tecnológicas que repercutiam rapidamente na configuração do imaginário urbano e na própria conformação do cotidiano das grandes cidades.

A música voltava-se para o espírito dos grandes movimentos de vanguarda do início do século. No Brasil, em 1946, surgia o manifesto do grupo Música Viva, criado pelo regente 
Hans Joachin Koellreutter, que futuramente iria ser Diretor do CDMCC de Tatuí, e integrado por jovens músicos, que atacava o conservadorismo nacionalista e retomava idéias de vanguarda. Os primeiros anos do pós-guerra sugerem a possibilidade de uma reviravolta no sentido da inovação, algumas dessas possibilidades podem ser encontradas em fatos como a Primeira Bienal de Arte de São Paulo (1951) onde pela primeira vez o Brasil fazia uma exposição de arte com efetiva repercussão internacional e que trazia ao contato do público e dos artistas locais o que de mais contemporâneo se realizava no exterior.

\section{O Primeiro Diretor do Conservatório de Tatuí - Eulico Mascarenhas de Queiroz (1954/1958)}

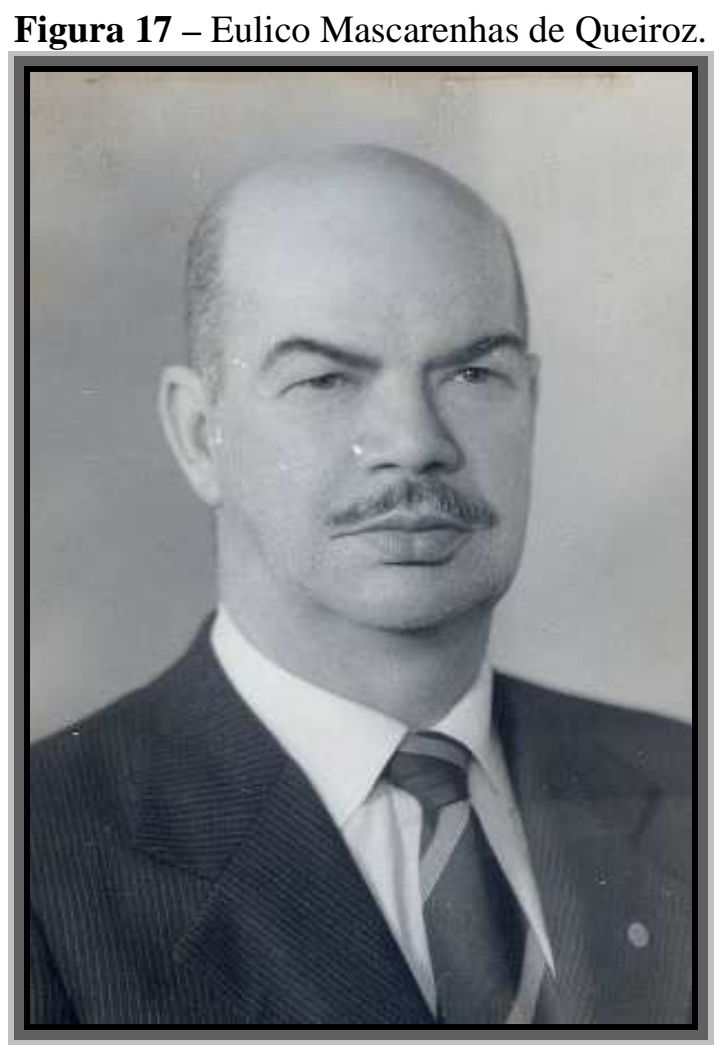

Fonte: Acervo do CDMCC.

A instalação do Conservatório de Tatuí foi "prometida" pelo então governador do Estado de São Paulo, Lucas Nogueira Garcez para o ano de 1952, que havia sido criado por lei em 51, porém sua instalação somente viria a ocorrer em 54, mais precisamente no dia 11 de agosto.

Com a inauguração oficial do Conservatório de Tatuí, inicia-se uma nova fase na história musical da cidade, porém o Conservatório de Tatuí inicia suas atividades com a problemática e a instabilidade da política cultural brasileira, mesmo tendo sua parte 
administrativa já definida, havia a necessidade de "justificar" sua existência numa cidade do interior e não na capital junto ao governo do Estado, porém o primeiro ponto a destacar nesse período é o apoio de políticos influentes que defendiam sua instalação em Tatuí.

$\mathrm{Na}$ foto abaixo, tirada durante o almoço oferecido às autoridades que participaram da solenidade de inauguração, vemos do lado direito, terceiro na mesa, usando óculos o Dr. Aniz Boneder e do lado direito, o terceiro, com as mãos entrelaçadas, o governador Lucas Nogueira Garcez.

Figura 18 - Inauguração oficial do Conservatório de Tatuí, 1954.

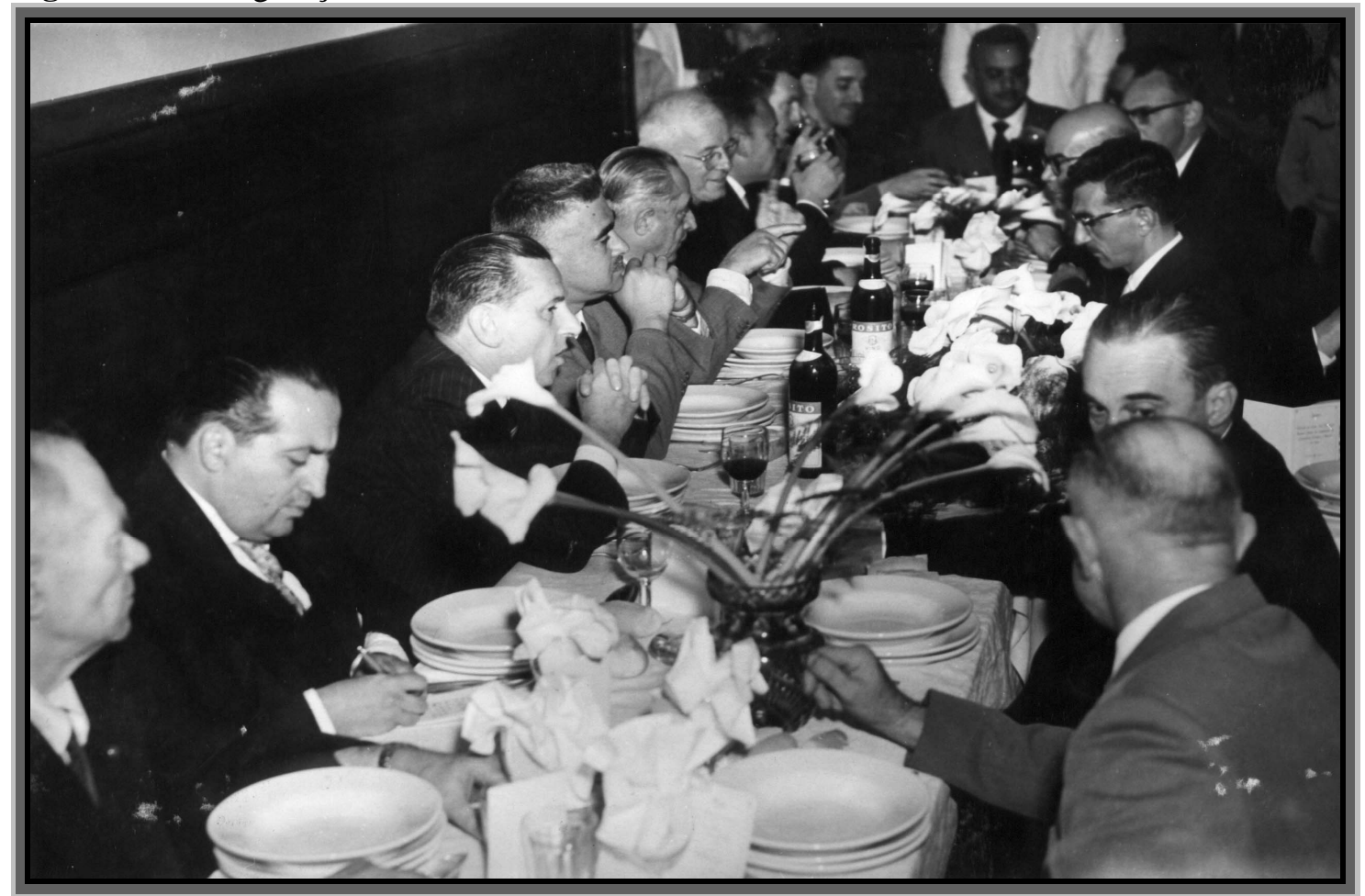

Fonte: Acervo do Museu de Tatuí.

Após a escola ser criada, mas antes de sua instalação, vários nomes foram cogitados para assumirem a direção do Conservatório de Tatuí. Dentre eles, o maestro Zacarias Zaltore, (regente do Teatro Municipal), que veio conhecer a cidade, mas não se interessou pela direção.

Finalmente foi escolhido, pelo governo, o dentista, jornalista e músico, Dr. Eulico Mascarenhas de Queiroz.

Eulico nasceu em Itapetininga no dia 31 de maio de 1903, filho do segundo casamento de Alfredo Teixeira de Queiróz com Noemi Mascarenhas, ,teve oito irmãos e com a esposa Luzia,cinco filhos.Já havia residido na cidade e fizera parte do conjunto de João Del Fiol como flautista, Redator musical da Secretaria de Estado da Cultura e também do Teatro 
Municipal de São Paulo, extremamente culto e preparado para o cargo que viria ocupar, Dr. Eulico Mascarenhas de Queiroz gozava de credibilidade no meio musical, e isso, de certa forma, ajudou-o nessa difícil tarefa de administrar a única escola de música do estado,sobretudo pela falta de referências.

Conforme Ata da primeira reunião extraordinária da Congregação do Conservatório Dramático e Musical de Tatuí, ocorrida em 16 de agosto de 1954, a instituição pertencia a Secretaria de Estado dos Negócios do Governo, demonstrando que não existia uma política cultural definida pelo Estado. O governo alugara o "casarão" da família Guedes na rua José Bonifácio, 245, no centro da cidade para a instalação do Conservatório de Tatuí.

A primeira reunião, ocorrida em 16/08/54, tendo como secretário que lavrou a ata, o Sr. Hélio Reali, a fim de tratar dos exames de habilitação do curso de Teoria e Solfejo dos alunos que já faziam cursos particulares de instrumento, estando portanto "adiantados" que outros alunos, porém nunca haviam feito estudos "regulares" dessas matérias, ficando resolvido que, depois de examinados por professores da área seriam classificados para a $2^{\mathrm{a}}$ série de Teoria e Solfejo. A reunião foi composta dos seguintes professores: Reno Bisaglia; Judith Cabette de Oliveira; Maria Ruth Luz; Maria Aparecida Holtz; Enny Vanni.

$\mathrm{Na}$ segunda reunião, ocorrida em 22/08/54, consta a presença de mais dois professores: Fritz August Ewin Jank e Enide Gomide Seiffarth (esposa do secretário do governo, Carlos Seiffarth).

Os professores eram músicos formados e foram contratados como catedráticos, isto é, não foram selecionados mediante concurso público, mas indicados por políticos, o que gerou ciúmes por parte de muitos professores e ao mesmo tempo, insegurança aos que haviam sido contratados devido ao ótimo salário que recebiam. Durante o ano letivo de 1954 a escola começa a receber alunos não só de Tatuí, mas também da região e até da cidade de São Paulo, passando a ser o centro coordenador de todos os trabalhos musicais da cidade.

No dia 16 de fevereiro de 1955, o Conservatório realiza sua primeira reunião ordinária, promovendo a estruturação pedagógica, de acordo com regulamento do novo órgão diretivo, o Conselho Técnico Administrativo do Conservatório de Tatuí, (CTA), sua existência foi aprovada por decreto $\mathrm{n}^{\circ} 23.238$ de $1^{\circ}$ de abril de 1954 , órgão do Conservatório de Tatuí, composta por professores eleitos a cada dois anos e tendo como presidente o diretor do Conservatório de Tatuí. Os professores eleitos foram Luis Cartolano, Marina Tereza Fillardi, Zita Alves do Amorim e Judith C. de Oliveira.

Nessa reunião fica decidida a grade curricular, para dar uniformidade ao curso de Teoria e Solfejo e a apresentação dos programas de Harmonia Elementar, Psicologia Musical, 
História da Música, curso de flauta, clarineta e demais instrumentos de madeira, (são considerados instrumentos de madeira os instrumentos que usam palheta para serem tocados). O programa de piano foi tomando por base o programa da Escola Nacional de Música da Universidade do Brasil, tornando os cursos da escola em cursos de excelência.

Ao se desenvolver o Conservatório de Tatuí, os organizadores passaram a se interessar cada vez mais pelo aperfeiçoamento e excelência musical, visando a qualidade dos musicistas, aumentando significativamente o nível didático dos alunos. Para tanto, procuraram investir na qualidade da educação musical, isto é, desenvolveram métodos que pudessem ser aplicados no processo musical. José dos Santos sugere ao seu professor de violino, Luiz Gonzaga Barbosa, que viesse dar aulas em Tatuí, pois os alunos da cidade que queriam seguir a carreira musical, depois de um certo nível, tinham que ir para São Paulo para darem prosseguimento aos estudos. O professor se interessou e como tinha um sobrinho muito influente na administração pública de São Paulo, foi contratado para ministrar aulas de violino em Tatuí, aumentando o número de instrumentos e contribuindo com a qualidade do ensino musical do recém criado Conservatório.

Spartaco Rossi, maestro da emissora "Rádio Nacional" de São Paulo, também contratado do Conservatório de Tatú, vinha todas as semanas dar aulas no Conservatório de Tatuí de flauta e instrumentos congêneres. Seu trabalho no Conservatório foi formidável, pois para atender a necessidade da escola, que tinha um grupo musical pequeno, ele reescrevia as peças musicais. Dotado de grande inteligência e reconhecida excelência musical iniciou a Orquestra Sinfônica de Amadores de Tatuí. João Del Fiol, funcionário da escola, (afinador de pianos) e idealizador da mesma, foi o primeiro violoncelo dessa orquestra e José dos Santos, (atualmente professor do Conservatório e um dos entrevistados) a primeira viola.

Aparece aí o fenômeno organizacional do Conservatório de Tatuí com o trabalho de pessoas com interesses comuns. O trabalho musical passa a ser feito de forma primorosa elevando a qualidade musical e causando profundas alterações no processo cultural de Tatuí, transformando a realidade existente num processo irreversível.

Nessa época, Jânio Quadros tinha vencido as eleições para governador do Estado de São Paulo e uma de suas metas era fechar o Conservatório de Tatuí, porém sua meta jamais se concretizou devido à influência política do deputado Amadeu Narciso Pieroni, que ainda era conhecido como sendo "dono da Assembléia". A escola tinha por volta de 30 alunos, então, Spartaco Rossi sempre conseguia, em dias de concerto, trazer músicos de São Paulo para "somarem" a orquestra e mostrar "produção" ao novo governo. 
Eulico Mascarenhas de Queiroz, considerado grande empreendedor e pessoa extremamente cativante, falece prematuramente no final do ano de 1958, seis meses antes havia falecido o deputado Amadeu Narciso Pieroni, deixando politicamente o Conservatório de Tatuí "órfão".

Conforme relato do ex-diretor do Conservatório de Tatuí, Antônio Carlos Neves Campos, que como o primeiro diretor sua formação é também em odontologia, Eulico Mascarenhas de Queiroz foi um excelente diretor e incentivador musical deixando muitos projetos a serem realizados.

\section{A Gestão Altino Santarém (1959/1960)}

Em 1959 é designado para o cargo de diretor do Conservatório Dramático e Musical "Dr. Carlos de Campos" de Tatuí, em virtude do falecimento do diretor Eulico Mascarenhas de Queiroz, o Sr. Altino Santarém, por indicação do governo e funcionário da Secretaria de Estado dos Negócios do Governo de São Paulo, não era músico e sim um administrador. O Governador do Estado de São Paulo nessa época era o Sr. Carlos Alberto de Carvalho Pinto $(1959-1963)$.

Segundo relatos de ex-funcionários que acompanharam sua gestão, não estava interessado em música e não teve ligação "afetiva" com a instituição, somente cumpriu seu papel de administrador. Seu período como diretor é pouco expressivo, entretanto o corpo docente não o tomou como modelo de "líder".

Conforme Ata da oitava reunião da Congregação do Conservatório Dramático e Musical "Dr. Carlos de Campos" de Tatuí, ocorrida em 06/12/59, o diretor, Sr. Altino Santarém, comunicou a todos os professores presentes que teriam a eleição do Conselho Técnico Administrativo, (CTA), para o biênio de 1960/1961, através de eleição secreta.

Os eleitos foram: professora Yolanda Rigonelli, (11 votos); Judith Cabette de Oliveira, (10 votos); maestro Spartaco Rossi, (09 votos) e professora Maria Ruth Luz, (08 votos).

Tomando a palavra o professor Spartaco Rossi agradece aos componentes pelo sucesso que tem logrado a Orquestra de Alunos e Amadores, sob sua regência, que não poupam esforços para dar sentido de projeção ao conjunto orquestral e conseqüentemente ao 
próprio Conservatório de Tatuí.Sugere aos professores que procurassem assistir as apresentações como forma de incentivo aos músicos e a ele, maestro.

Suas palavras causaram efeito e foi decidido, nessa reunião, que quando houvesse apresentações, os familiares dos músicos e todos os professores seriam convidados a participarem do evento, sendo que os convites seriam emitidos pela secretaria, prática adotada até hoje. Notamos que a partir dessa reunião, os professores tomaram como "líder" pedagógico musical, o maestro Spartaco Rossi.

Na nona reunião da Congregação do CDMCC de Tatuí, ocorrida em 09/07/60, o Sr. Diretor, Altino Santarém, relata a situação do Conservatório de Tatuí, seu modo de agir desde sua posse até a presente data, afirmando que aceitou pacificamente o regime de trabalho dos professores e que em face de vários problemas técnicos surgidos, se convencera de que para ser diretor do CDMCC de Tatuí, tinha quase que por obrigação, ser músico. Porém na reunião seguinte, ocorrida em 13/08/61, o diretor, Sr. Altino Santarém ressalta aos professores que seu trabalho se restringiria apenas ao âmbito administrativo, ficando o setor técnico pedagógico, com os problemas atuais e futuros, exclusivamente ao Conselho Técnico Administrativo (C.T.A) e à Congregação. Para tal atitude alegou a "inércia" dos professores, porém o maestro e professor Spartaco Rossi refutou as críticas ressaltando o trabalho em favor da cultura musical desenvolvido por todos os professores do Conservatório de Tatuí.

Nesse mesmo dia o Conservatório iria receber a visita do Dr. Márcio Ribeiro Porto, secretário de Estado dos Negócios do Governo, para ser discutidos assuntos de interesse do Conservatório.

Organizações musicais como a de Tatuí, sustentam sua autoridade enquanto detentoras de capital cultural. Seus idealizadores movidos pelo mesmo ideal tornaram possível a administração e sua continuidade, passando a agir em nome da organização e "facilitando" a tomada de decisões para com aqueles que formalmente foram designados.

Em diferentes graus de consciência e de ação, os novos espaços organizacionais praticam hoje esse conceito, através da estruturação de meios que permitem a difusão das artes, agindo no sentido de estabelecer a possibilidade individual ou coletiva da criação, participando, assim, do processo de construção da cultura. 


\section{A Gestão Yolanda Rigonelli (1960/1963)}

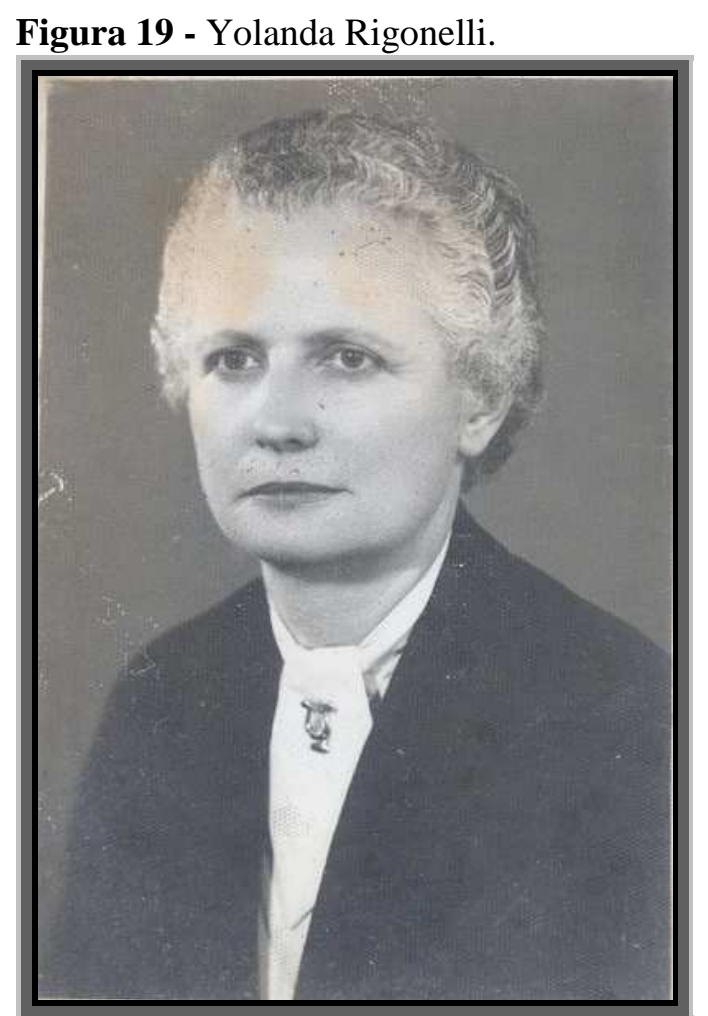

Fonte: Acervo do CDMCC.

A professora de harmonia Yolanda Rigonelli assume a direção do Conservatório Dramático e Musical "Dr. Carlos de Campos" de Tatuí num período de intensas transformações sociais e culturais em nosso país e com a incumbência de resgatar os projetos musicais que durante a gestão do diretor Altino Santarém não foram realizados. No ano de 1961 é regulamentada a primeira Lei de Diretrizes e Bases da Educação, (LDB 4024/61), que transformava o ensino musical para um caráter pedagógico e a Lei Federal nº. 3857/61, que criava a Ordem dos Músicos do Brasil.

Conforme ata de 22/02/62, o maestro e professor Spartaco Rossi elogia o trabalho de todos os professores, desde a data de instalação do Conservatório de Tatuí (1954), até a presente data, refutando as críticas do diretor anterior, Sr. Altino Santarém, dirigida ao corpo docente do CDMCC. A esse respeito o professor Alois Ellmerich, ressalta que o Sr. Altino Santarém, escriturário do funcionalismo público, leigo na área musical, dirigiu críticas ao corpo docente do CDMCC de Tatuí, sendo que os mesmos não deveriam tomar conhecimento de tais acusações, pois, eram oriundas de pessoa sem a mínima autoridade no assunto pedagógico musical. 


\section{Criação da "Semana da Música"}

O problema da análise crítica da aprendizagem musical representou a criação da "Semana da Música" em Tatuí pela nova diretora do Conservatório, que tinha por finalidade a apresentação dos alunos, durante a segunda semana do mês de novembro, (dia 22 de novembro é comemorado o dia da música e dos músicos), para que fosse demonstrado o aproveitamento musical durante o ano letivo. $\mathrm{Na}$ "1 ${ }^{\mathrm{a}}$ Semana da Música", o quarteto composto por João Del Fiol, José dos Santos, Mateus Jacob Hessel e “Zico” Lázaro Bertrami se apresentaram tocando composições de Mozart, causando boa impressão e excelente repercussão para a escola.

$\mathrm{Na}$ próxima foto, a diretora Yolanda Rigonelli encontra-se em pé presidindo a abertura da "2ª Semana da Música”, ocorrida no ano de 1962, já constando como evento fixo do Conservatório de Tatuí, tradição que é mantida até hoje.

Figura 20 - Comemoração da Semana da Música, 1962. 2ª Semana da Música.

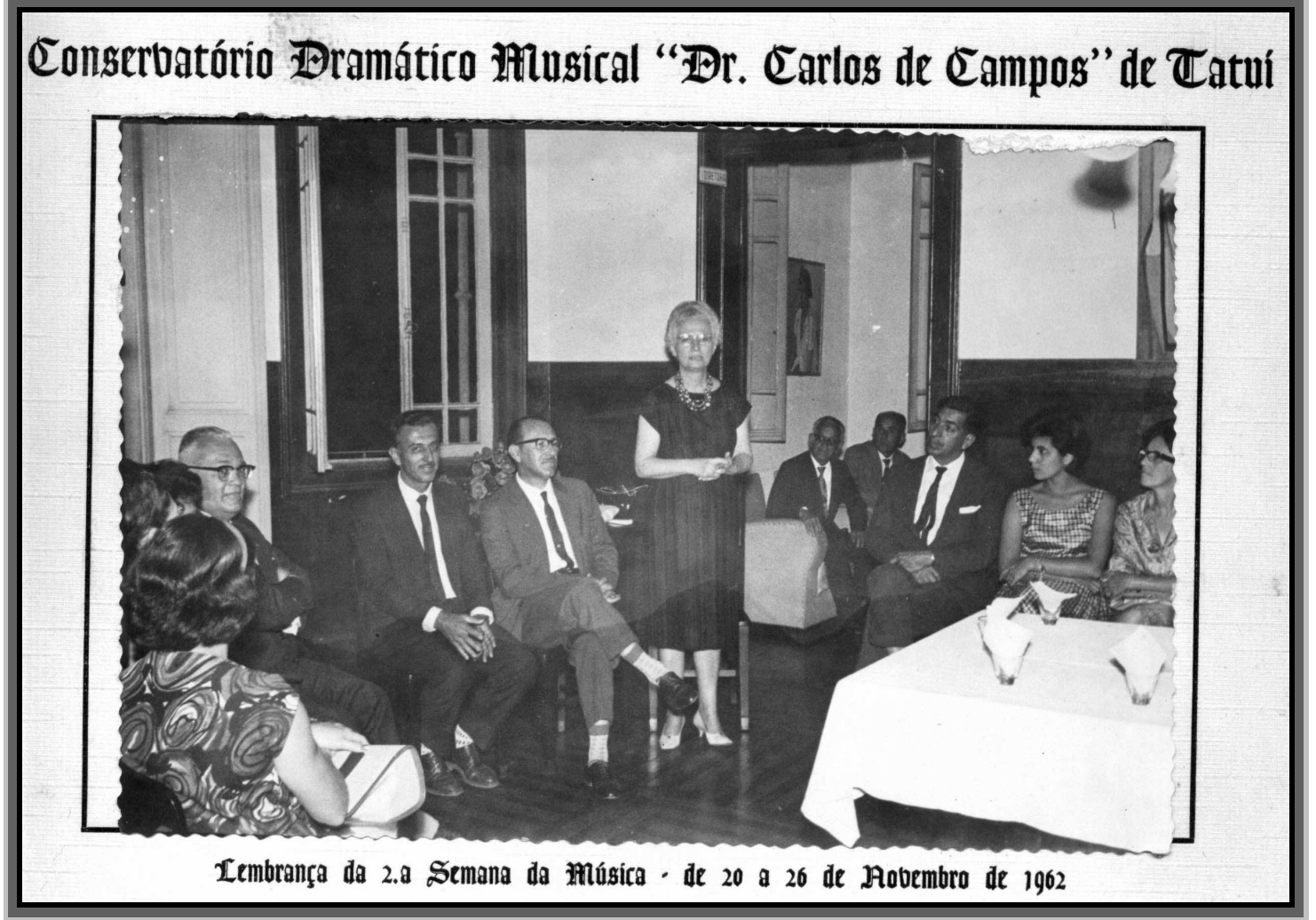

Fonte: Acervo do Museu de Tatuí. 
Conforme relato ex-diretor do CDMCC de Tatuí, Antonio Carlos Neves, a professora Yolanda Rigonelli entrou na direção do Conservatório de Tatuí e deu uma "guinada" na escola. Conceituada no meio musical foi a pessoa certa no período em que a escola estava precisando. O maestro Neves se formou na época de sua gestão, com apenas 16 anos de idade, mesmo tendo cumprido todas as etapas necessárias para se diplomar e tendo notas suficientes para a graduação, não poderia receber seu diploma por não ter "idade", porém a diretora, conseguiu que ele recebesse seu diploma, devido a seus conhecimentos sobre a legislação musical e amparada pela lei.

Temos uma legislação a ser obedecida só que em determinadas circunstâncias, que não irá trazer nenhuma conseqüência danosa, pelo contrário, será um estímulo, foram os argumentos da diretora Yolanda Rigonelli e o diploma foi aceito. 
"As formas musicais reproduzem internamente as estruturas sociais."

(Theodor W. Adorno) 


\section{CAPÍTULO IV}

\section{O CONSERVATÓRIO DRAMÁTICO E MUSICAL “DR. CARLOS DE CAMPOS” DE TATUÍ NO PERÍODO DA DITADURA MILITAR}

\section{A gestão Djalma Carvalho Moreira (1964/1968)}

A década de 1960 está inserida num período de crescimento econômico e tecnológico mundial. O Brasil é tido como uma sociedade coletivista, com uma classe trabalhadora urbana inserida no movimento nacionalista. Distanciada do poder urbano, a classe trabalhadora rural permanecia no secular controle a que estava submetida.

O Estado Militar promove no Brasil o capitalismo, fazendo com que os imperativos de ordem econômica passem a predominar também na esfera da cultura. O Estado é o agente da modernização. A preocupação com a cultura é encarada como instrumento de transformação social e com características e aspectos que emergem de traços culturais nacionalistas e, conseqüentemente atrelada com a política. Os traços estão no inconsciente, mas podem ser percebidos e sentidos naturalmente.

Modelos de gestão são importados de outros países e implementados em organizações brasileiras, gerando conflitos pelo fato de os valores culturais serem diferentes, com isso, as organizações brasileiras precisam mudar as atitudes e percepções de seus membros. A implantação de novos sistemas, resultado de investimento do Estado, é similar aos interesses dos gestores da cultura, mesmo que possam existir diferenças, segue a lógica do mercado, lógica do desenvolvimento do capitalismo que marcha inexoravelmente para abranger todos os aspectos da vida social e que leva o Brasil a integrar o mercado internacional.

A gestão Djalma Carvalho Moreira, advogado, nomeado pelo governo como Diretor Substituto é inicialmente marcada pela instabilidade do Conservatório de Tatuí permanecer na cidade. Conforme Ata da Décima Sexta Reunião Ordinária de 21 de março de 1964, página 38, "havia um plano para a transferência do estabelecimento em etapas, onde a prioridade seria a instalação dos referidos cursos, na Capital”. 
Figura 21 - Reprodução da Ata da $16^{\text {a }}$ Reunião Ordinária de 21/03/1964

\section{Ata IA $16 \triangleq$ Rencito or} divaria in cougregatio do qauserontirio deamstico e Munieal

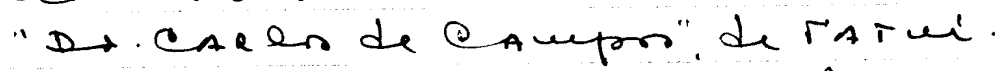
DAta:-21-3-196er. Voal:-Reen Jri Ionifakio, gersen TATHi.

$$
\text { Com a paresucera dos }
$$

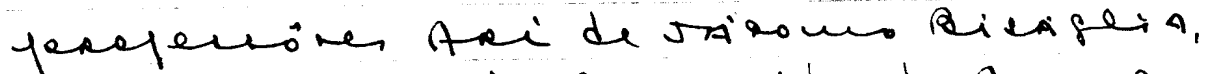
Aloto elemerich, Beneasita de Arruar

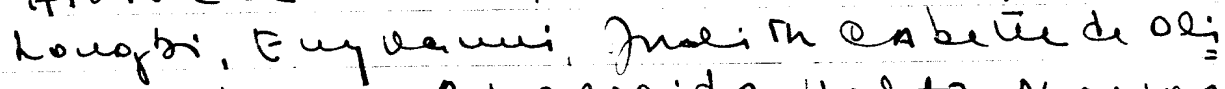

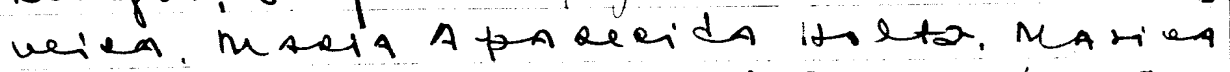
LAgA Barbosa, Reur BisigeiA Ru Bolli

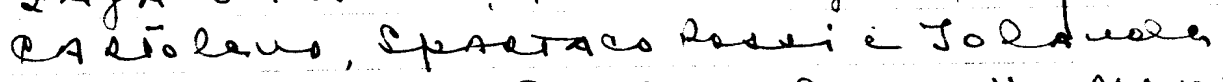

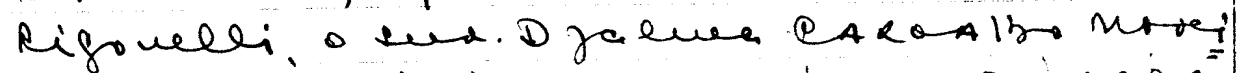

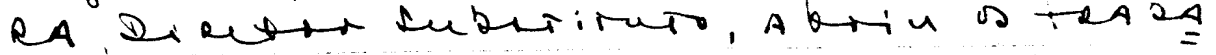

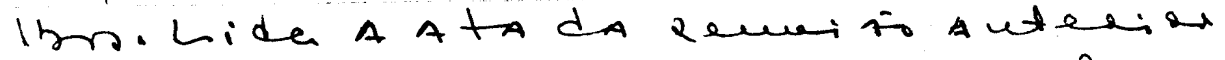

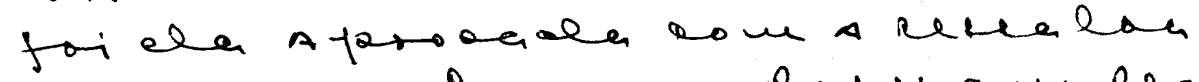

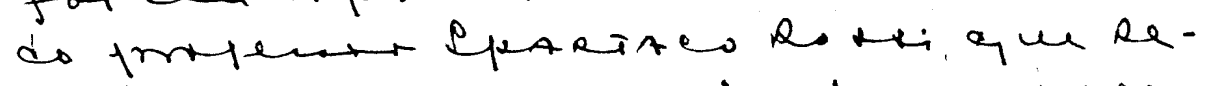

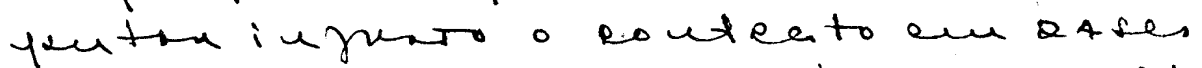

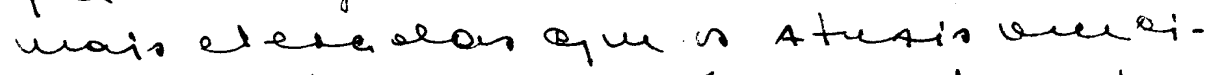
unutor de far+ferbore estesubr as dorpos bounte do Dounerdatitio Hada nouran de viaturidade c

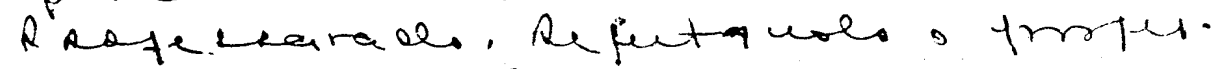

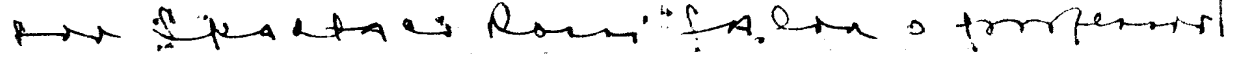




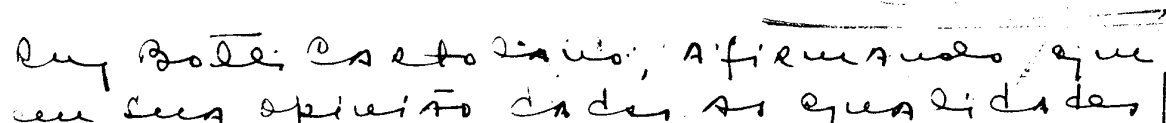

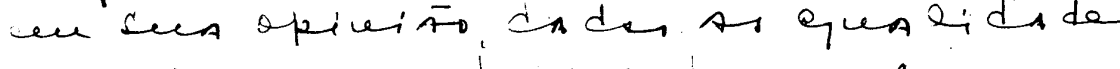

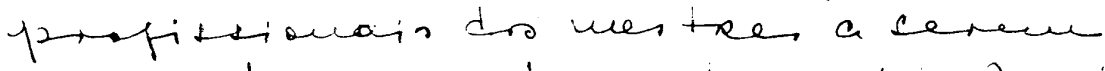
couteataden Aebzoa de wuita hati-

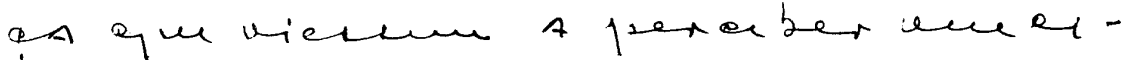

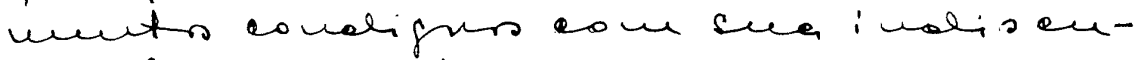

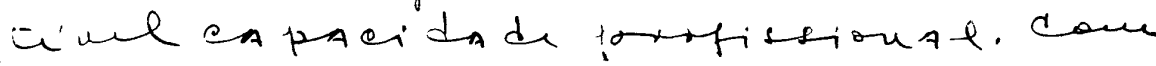
a paranta o un. Direthi ieformon

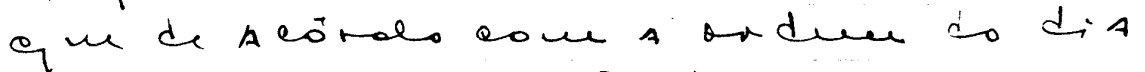

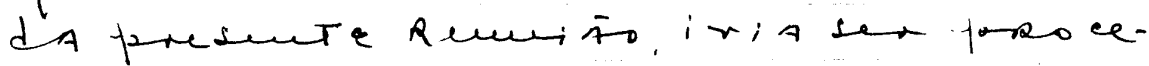
didA a eleign do D.T.A. para diéuio $64 / 65<$, eA SUA interpertae, ds metifrs $66.67, i$ the $i$, do Reguen-

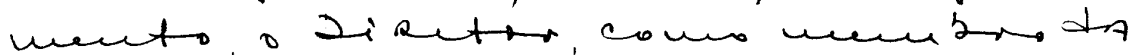
cougregado, tambin teris direito de voto, pos'dunal, entertanos, qual=

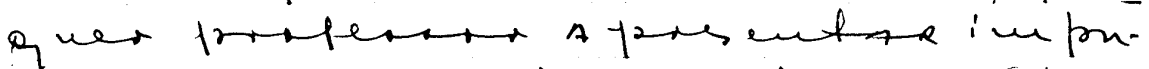

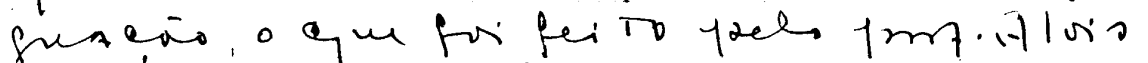
elinerict. Coutimut wab ean $A$

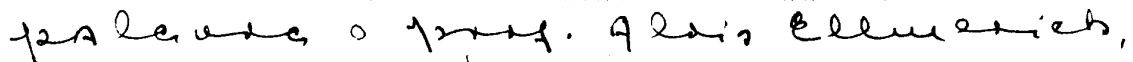

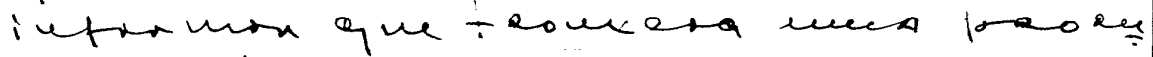
CA Q

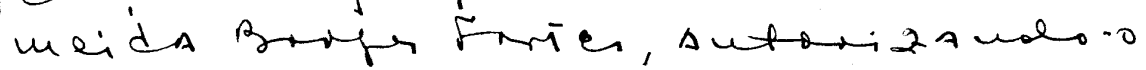

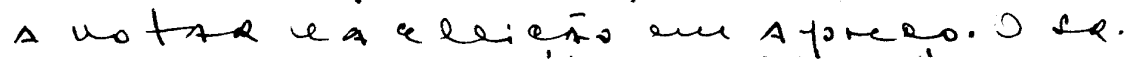

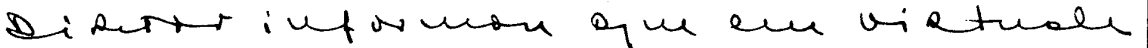
de ser a a leidio en tarma de bira

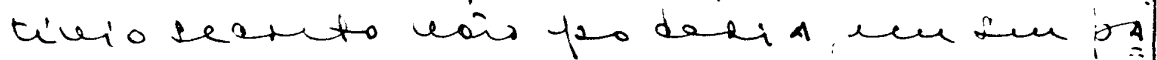

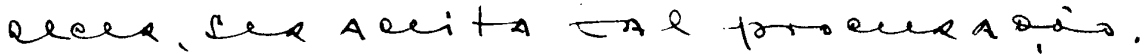
$M$ is obstave, iria tubmeter o As-

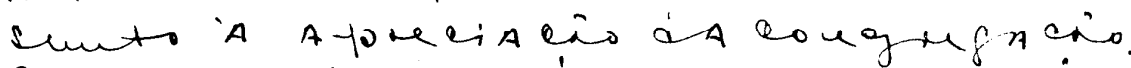
Psto a uotor $912+$ persires uega -

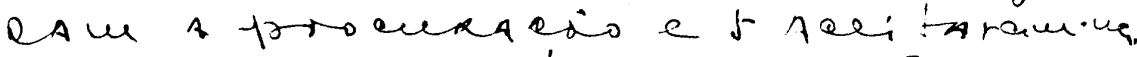

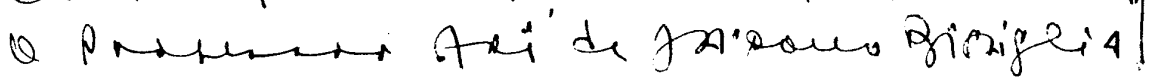




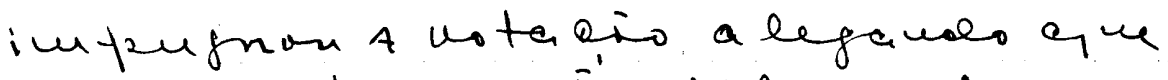

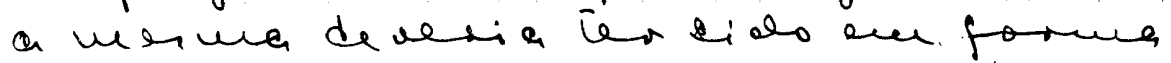

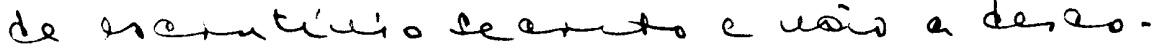

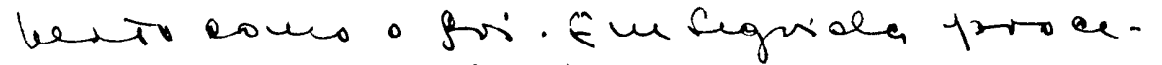
durse a luirio do a, r.A. pror es aruVinis serrio, verificendo-te o legminte Resuetado:- A Ri de JAंcoms bisighin.5

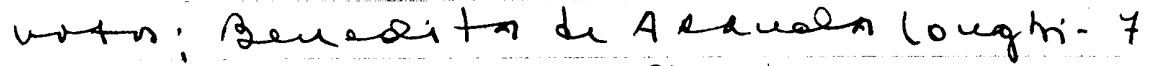

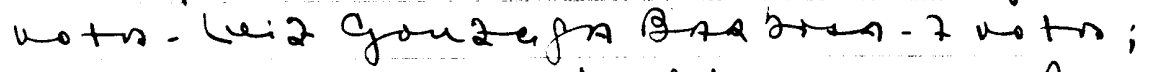

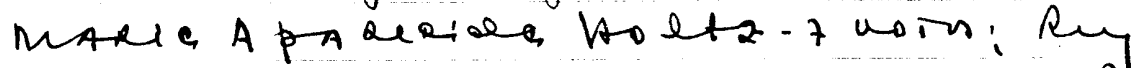

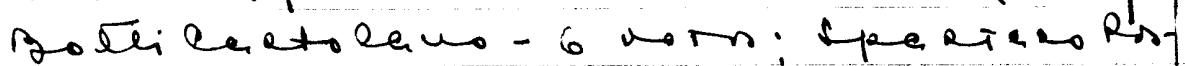

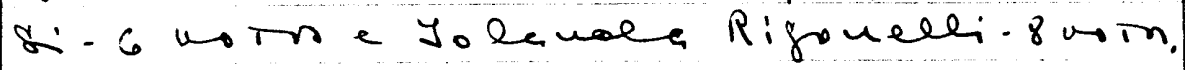

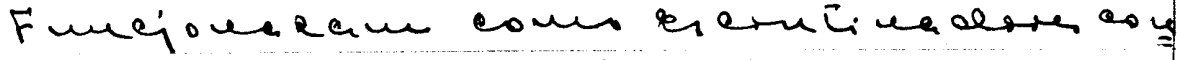

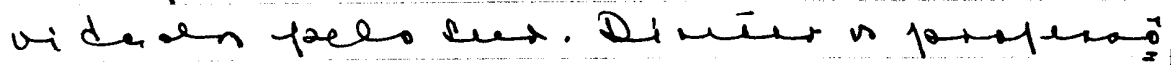

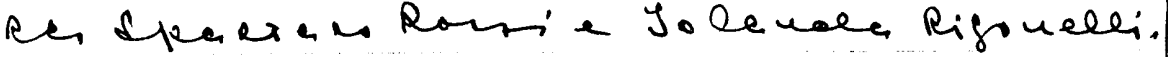

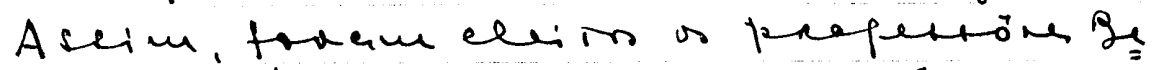
uedita de A Ranale lougtri luid fousage DARbrse, Maric A perecriale Itoltze

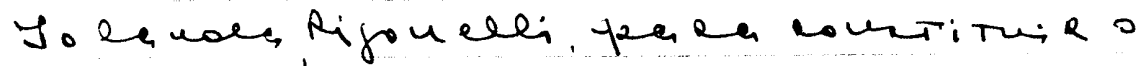

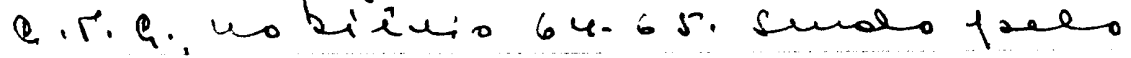
$H$. Dirter dexid amente enprorado veebunds pat pormprata L pro-

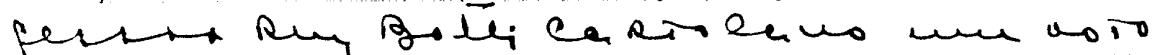
de coufiauter e a polants, tradentiald

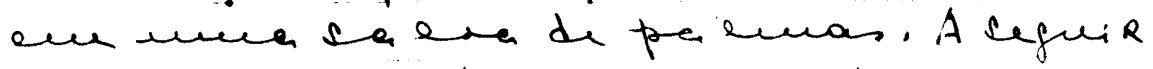
- un. Dimior diserrren sóbre o yoro-

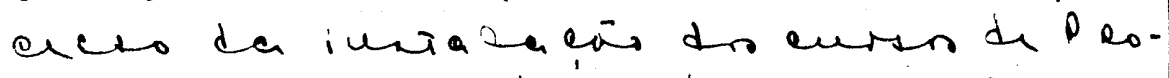

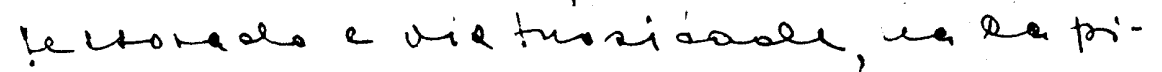

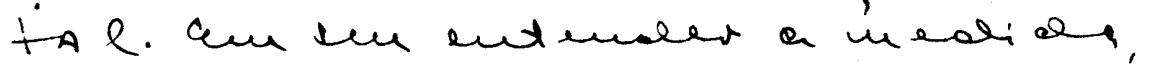

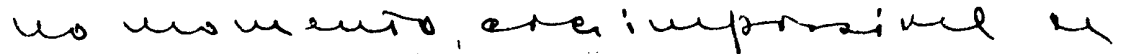

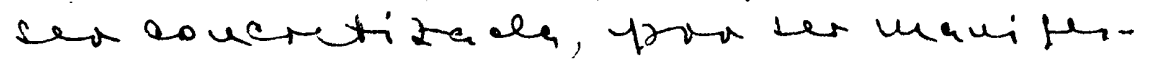
tamente ilegal, thels ene vista des

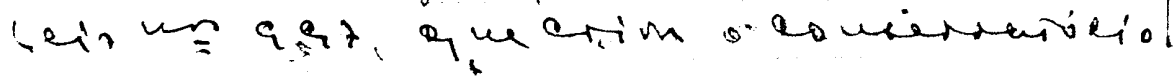


e a de Divetrizer e Bares. A ése Repileito

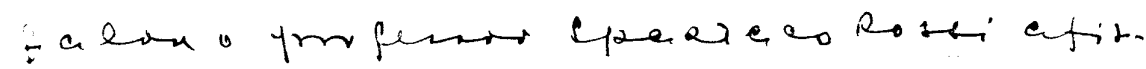

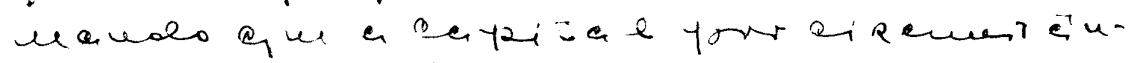
dian obrian berie o ambiente ideal pá

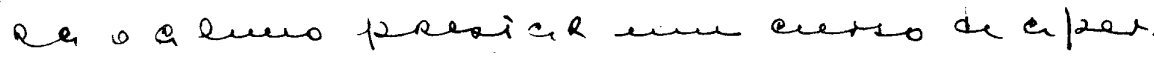

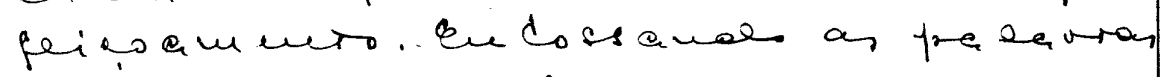

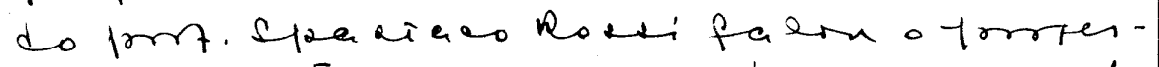

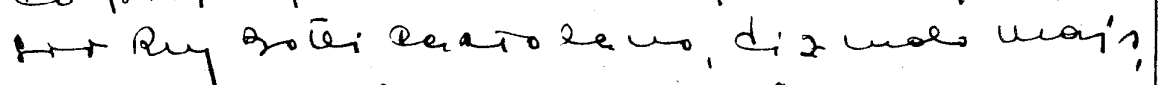
que euctuinabs a preato finaukeino

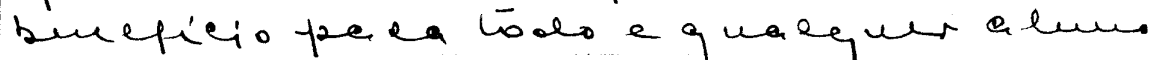
do interim, setia Cotal, voliandes a

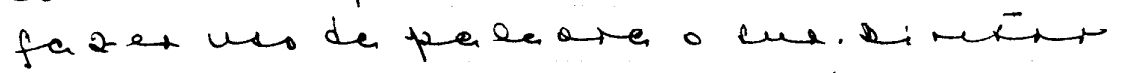
afirmon que of a thutio erea bariante

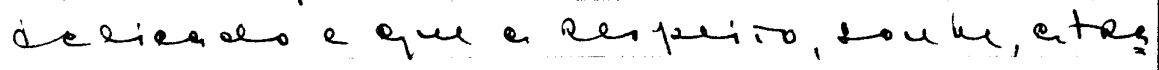
wir do da. Ubiearace Dolikio Hender, covenetra midieo da leartiana do

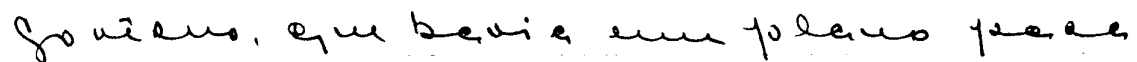
a transferiveia do exiabelecinento en

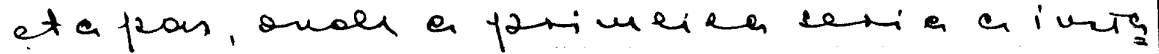

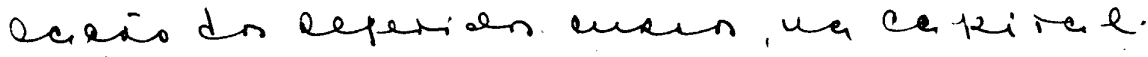

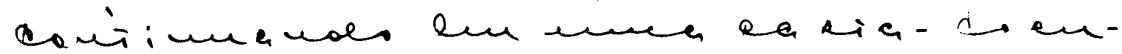
mut integranie do toraents en

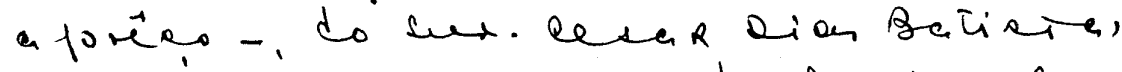

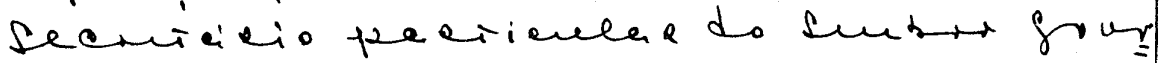
uader onde tue funbstia se depere a

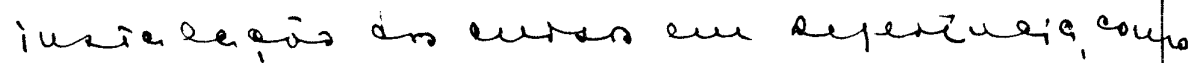

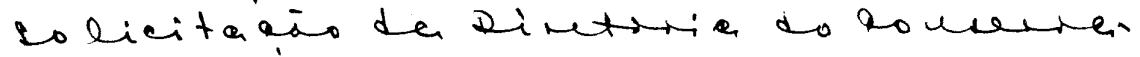

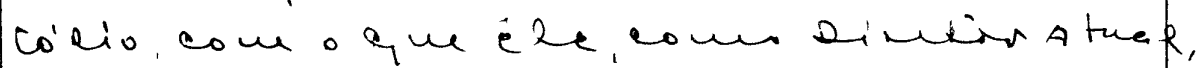

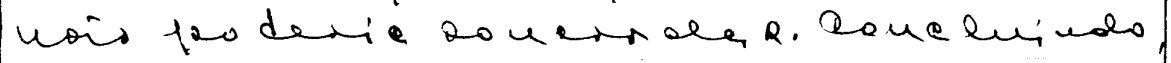

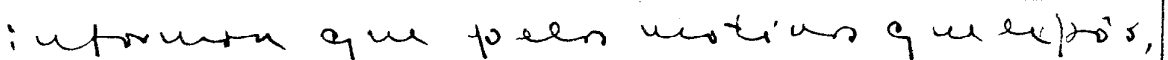

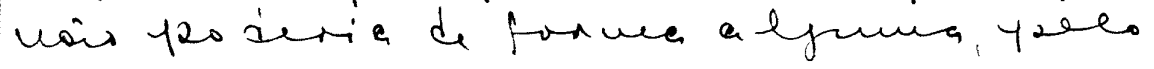

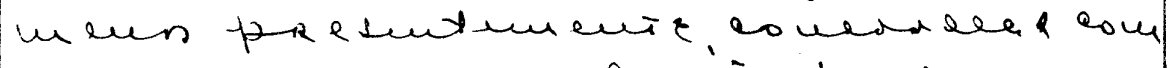

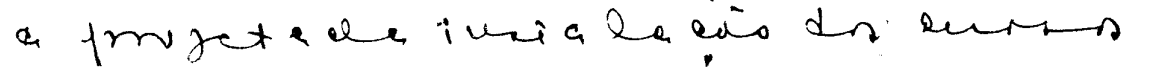




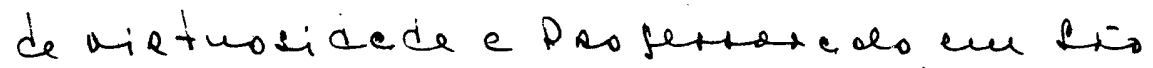

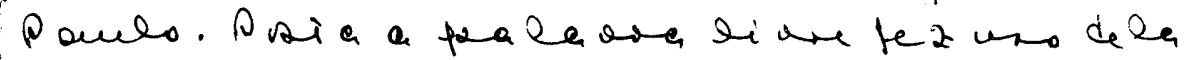

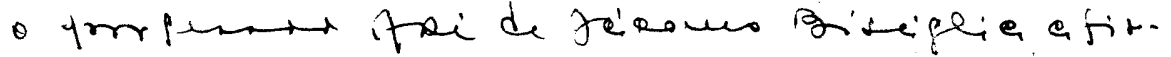

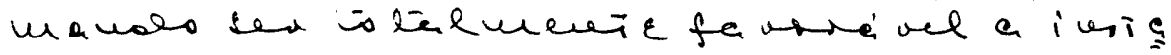
cacis dr entrs us tocanic as beneficio

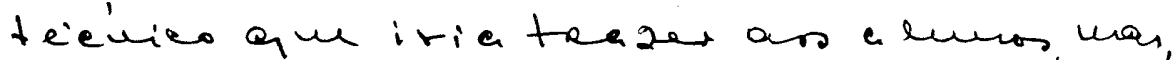
avia dino poro punba que te ariatse

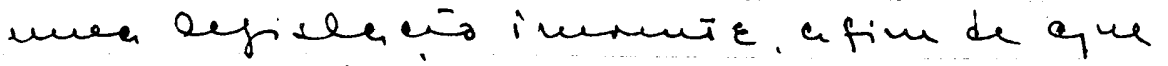

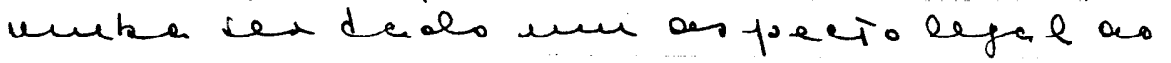

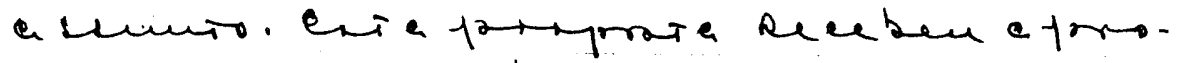
varito macinime da Rougregacio. Ples

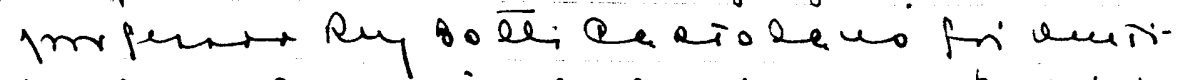

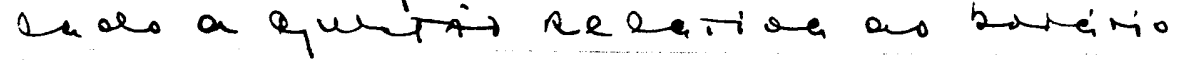

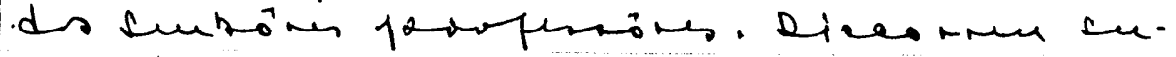

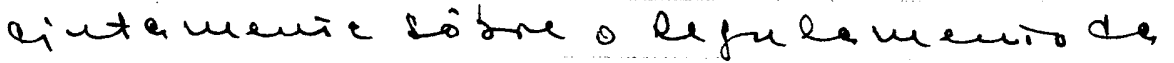

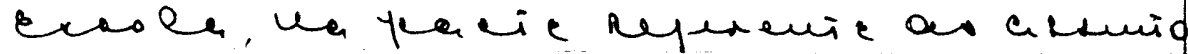
a firmands qu no hetino becmederio a iutarjeseracio è deda como" Ho-

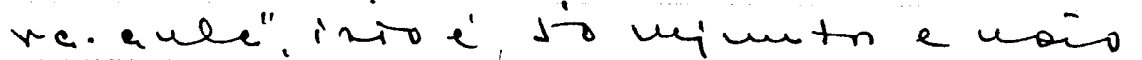
6o. Reletivemente as decanto de

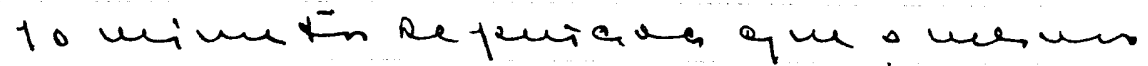

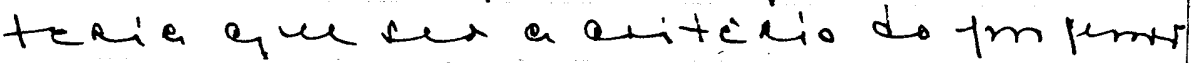

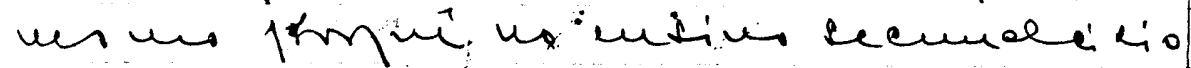
era fertiolo è vistandso decento

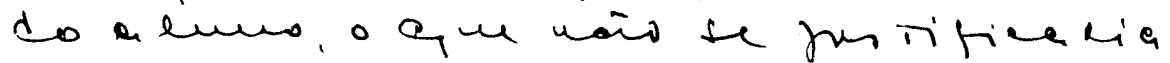

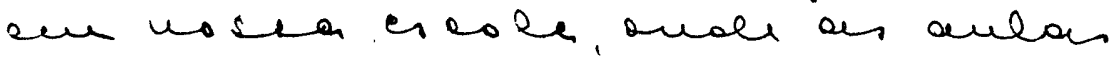
cois de capiter i ualitidual, fiar

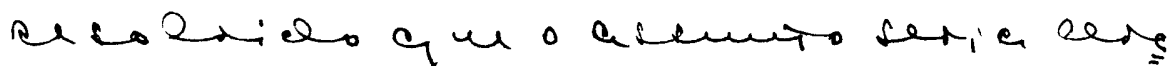

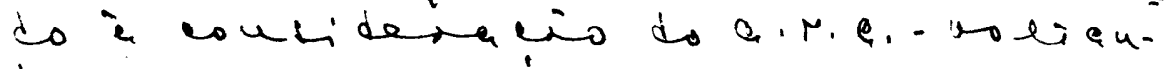
do a tares uto de palaura o thes.

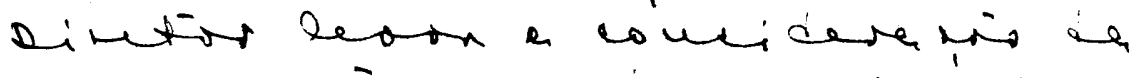

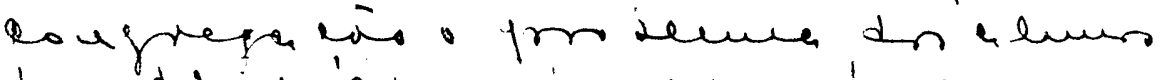
Lan diraitieiman siviórie de Muticel 


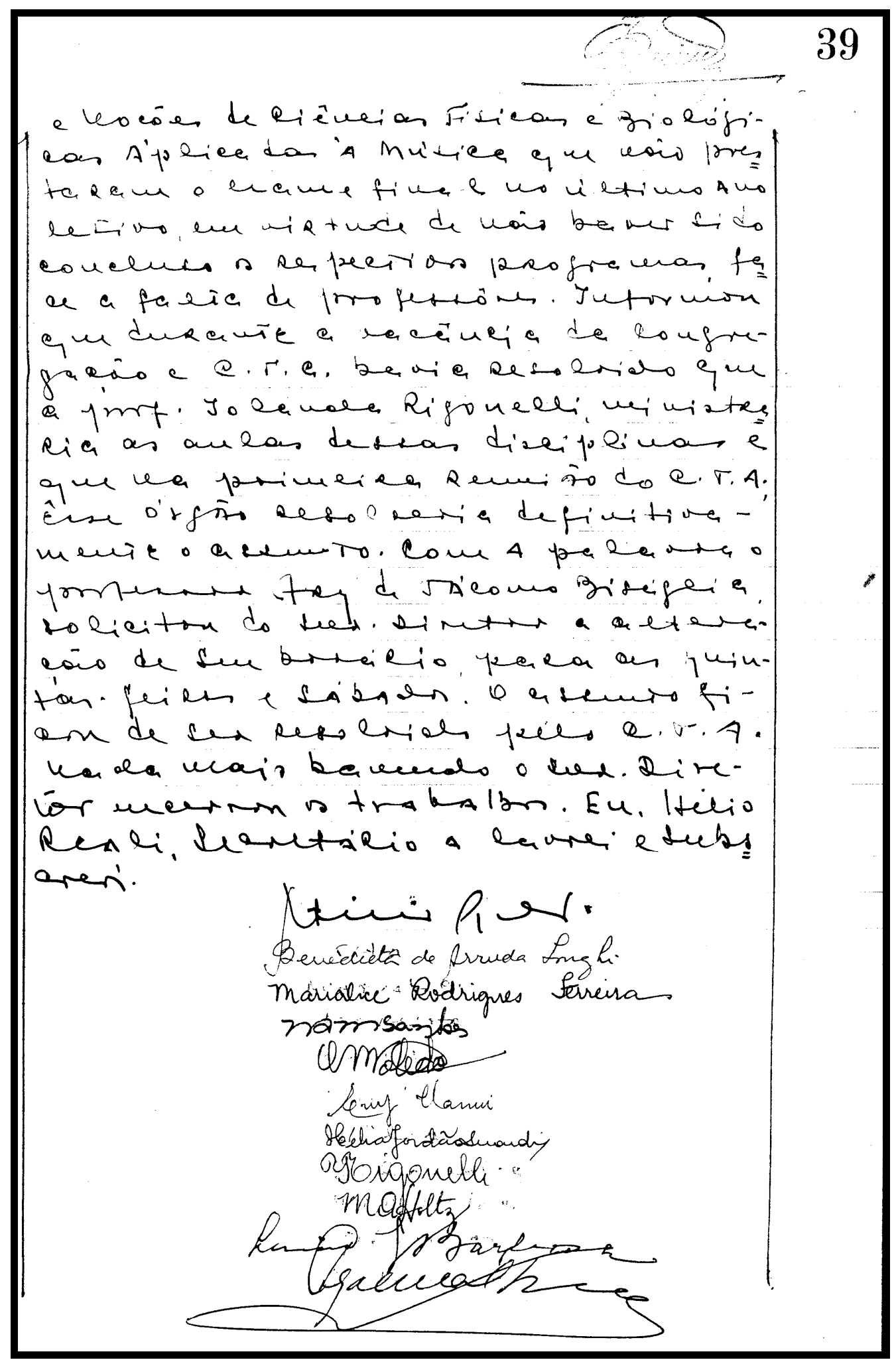

Fonte: Acervo do CDMCC de Tatuí.

Organizações culturais criativas, que estão passando por processos de instabilidade como o CDMCC de Tatuí são marcadas pelas iniciativas de seus membros. Conforme Ata Vigésima da Reunião da Congregação do CDMCC de Tatuí ocorrida em 13/12/1966, o Sr. Diretor Substituto Djalma de Carvalho Moreira agradece ao corpo docente composto por: 
Dirce Bertrame Teixeira; Eny Vanni; Eunice Schnaider Madeira Gagliardi; Flora dos Santos Silveira Campos; Hebe Hermeto Villaça; Hélia Jordão Suardi; Irinéa Marques Souza; Ives Rudner Schmidt; Luiz Gonzaga Barbosa; Maria Aparecida Holtz; Maria Aparecida Moreira Santos; Maria Aparecida Serafim Oliveira; Marialice Rodrigues Ferreira; Marina Thereza Filardi Peixoto; Nilson Lombardi; Odete de Mello Toledo; Paulino Pellegrini; Spartaco Rossi e Yolanda Rigonelli pela colaboração recebida durante o ano letivo de 1966 pelas atividades desenvolvidas.

Podemos observar que os membros do CDMCC de Tatuí desenvolveram atividades não somente durante a "Semana da Música", prática que ocorria nos anos anteriores, mas durante todo o ano letivo foram oferecidas atividades ao público sobre o trabalho desenvolvido pela escola, o que ocorre até os dias de hoje. Porém mesmo demonstrando o trabalho didático-pedagógico da escola, direção, professores e músicos do CDMCC de Tatuí não conseguiram justificar a permanência da escola em Tatuí. Conforme entrevista do Sr. João Eurico de Melo Toledo, secretário aposentado do CDMCC de Tatuí, o objetivo da transferência da escola foi se consolidando e teve o seu ponto máximo com a intervenção de músicos como Diogo Pacheco (maestro) e João Carlos Martins (pianista), com artigo publicado no jornal "O Estado de São Paulo" (não foi possível encontrar essa publicação). O CDMCC de Tatuí estava com os dias contados na cidade, porém, o professor do CDMCC de Tatuí, José Coelho de Almeida, apoiado pelo deputado Dr. Nelson Marcondes do Amaral foi ao Palácio do Governo conversar com o governador Roberto Costa de Abreu Sodré que lhe deu o prazo de um ano como diretor do CDMCC de Tatuí para reorganizar a escola, caso contrário a cidade perderia o Conservatório. Nesse cenário organizacional, nos deparamos com o macro- sistema interferindo diretamente no micro-sistema.

A última Reunião Ordinária assinada pelo Sr. Diretor Substituto Djalma de Carvalho Moreira ocorreu em 13/02/1968, constando na Ata Vigésima Segunda. 


\section{A gestão Professor José Coelho de Almeida (1968/1983)}

O ano de 1968 foi marcado por grandes transformações políticas, não somente no mundo como também em Tatuí. A primeira providência do novo diretor foi marcar uma reunião. Durante a Quarta Reunião Extraordinária da Congregação do CDMCC de Tatuí ocorrida em 20/05/1968 o novo diretor, professor do CDMCC de Tatuí, José Coelho de Almeida, ressaltou que seu principal empenho na direção do CDMCC de Tatuí era da escola atingir o lugar que merece no contexto artístico musical do Estado de São Paulo. Afirmou que era do conhecimento de todos que o Sr. Governador, (Abreu Sodré - 1967 - 1971), quase fechou o CDMCC de Tatuí, o que só não se concretizou não o fazendo graças à influência dos deputados Dr. Nelson Marcondes do Amaral e Nelson Pereira que argumentaram e convenceram o Sr. Governador de que, com a nomeação de um diretor formado em música, a escola alcançaria seu objetivo principal que era a formação de técnicos de grau médio e difusão artístico cultural e que o anseio dos professores e de todos seria atingido com a consolidação definitiva do CDMCC em Tatuí.

Ressaltou o seguinte: a necessidade da mudança de prédio devido às instalações precárias do prédio (falta de espaço); as vantagens da integração da escola na Lei de Diretrizes e Bases; a instalação de uma comissão de professores para efetuarem estudo de peças contemporâneas e tradicionais para permitir que a educação musical seja eclética; o planejamento da programação de um conteúdo programático a ser cumprida pelos alunos no início do ano a fim de se estabelecer o repertório a ser executado pelo aluno; a uniformização da técnica pedagógica para que alunos transferidos de um para outro professor não fosse prejudicado; o planejamento do curso História da Música pelo método analítico.

Usando de grande sutileza, nessa mesma reunião, o Diretor, professor José Coelho de Almeida, consulta a professora Hebe Hermeto Villaça sobre a possibilidade da apresentação de seus alunos da "Sinfonia do Brinquedo" de Haydn em homenagem à mãe do pianista João Carlos Martins - o mesmo que havia cogitado a transferência do CDMCC de Tatuí - e da possibilidade dos melhores alunos da escola se apresentarem no Teatro Municipal de São Paulo.

Em situação completamente diferente, porém de extrema relevância como justificativa das mudanças ocorridas, podemos citar o caso relatado no livro de De Masi, (1999:274), “A Emoção e a Regra”, sobre a escolha do novo diretor Max Horkheimer, para o Instituto de Pesquisa Social de Frankfurt, “(...), tornaram-se evidentes as mudanças 
introduzidas no Instituto sob a direção de Horkheimer", o mesmo fato ocorre com a nomeação do professor de flauta transversal do CDMCC de Tatuí para a direção.

Na nova condição de instituição solidificada na cidade de Tatuí e por intermédio do Deputado Orlando Gabriel Zancaner, Secretário da Cultura, Esporte e Turismo, o CDMCC de Tatuí recebe instrumentos de sopro, cordas e fanfarra no valor de vinte e quatro milhões de cruzeiros antigos. O clima cultural, as atividades musicais e pedagógicas do CDMCC de Tatuí durante o ano de 1968 foram intensas, foi um período de crescimento e impulso no cenário artístico da cidade. Em 1969, o CDMCC de Tatuí muda-se para o prédio da antiga Câmara Municipal na Rua São Bento, $n^{\circ} 415$, prédio "alugado" pela Prefeitura da cidade por preço simbólico.

Figura 22 - José Coelho de Almeida discursando na inauguração do novo prédio do CDMCC 1969.

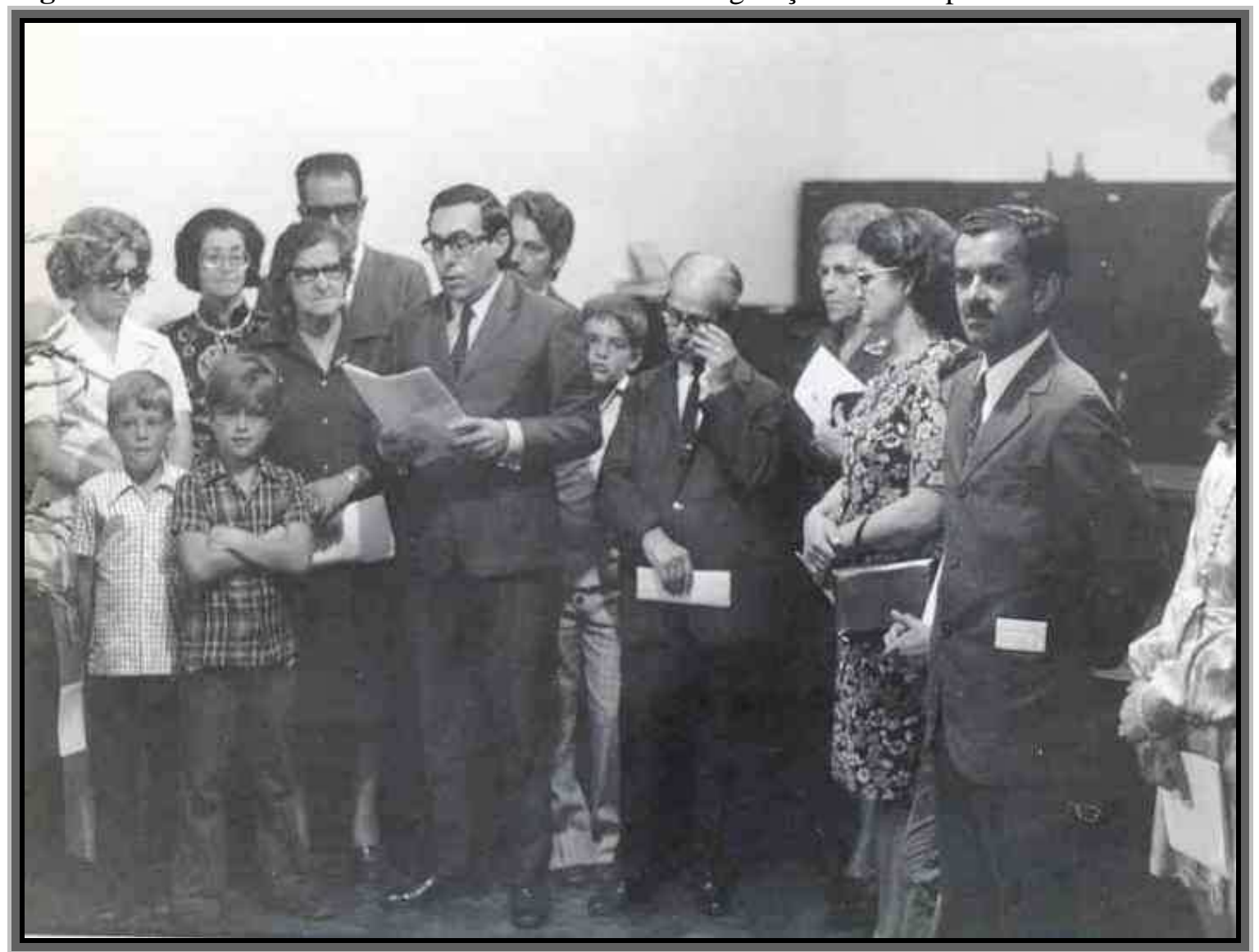

Fonte: Acervo do CDMCC de Tatuí. 


\section{A projeção do Conservatório de Tatuí no cenário artístico brasileiro e internacional}

A extraordinária capacidade organizativa musical e administrativa do professor José Coelho de Almeida, seu carisma e intransigência referente às questões musicais, conforme relato dos entrevistados, além de seu pensamento visionário, explicam a influência exercida durante os anos que este esteve à frente da direção do CDMCC de Tatuí. Toda a estrutura e grande parte do instrumental existente atualmente no Conservatório foram adquiridas em sua gestão.

Este Diretor soube aproveitar o momento político favorável ao crescimento e o fez de maneira prodigiosa e, a cima de tudo, com qualidade, conseguindo trazer para Tatuí grandes nomes do cenário musical nacional e internacional para lecionar regularmente na escola, ou como palestrante, gerando grande satisfação no corpo docente e discente que se recordam até os dias atuais com grande apreço.

Figura 23 - Airton Pinto ao violino.

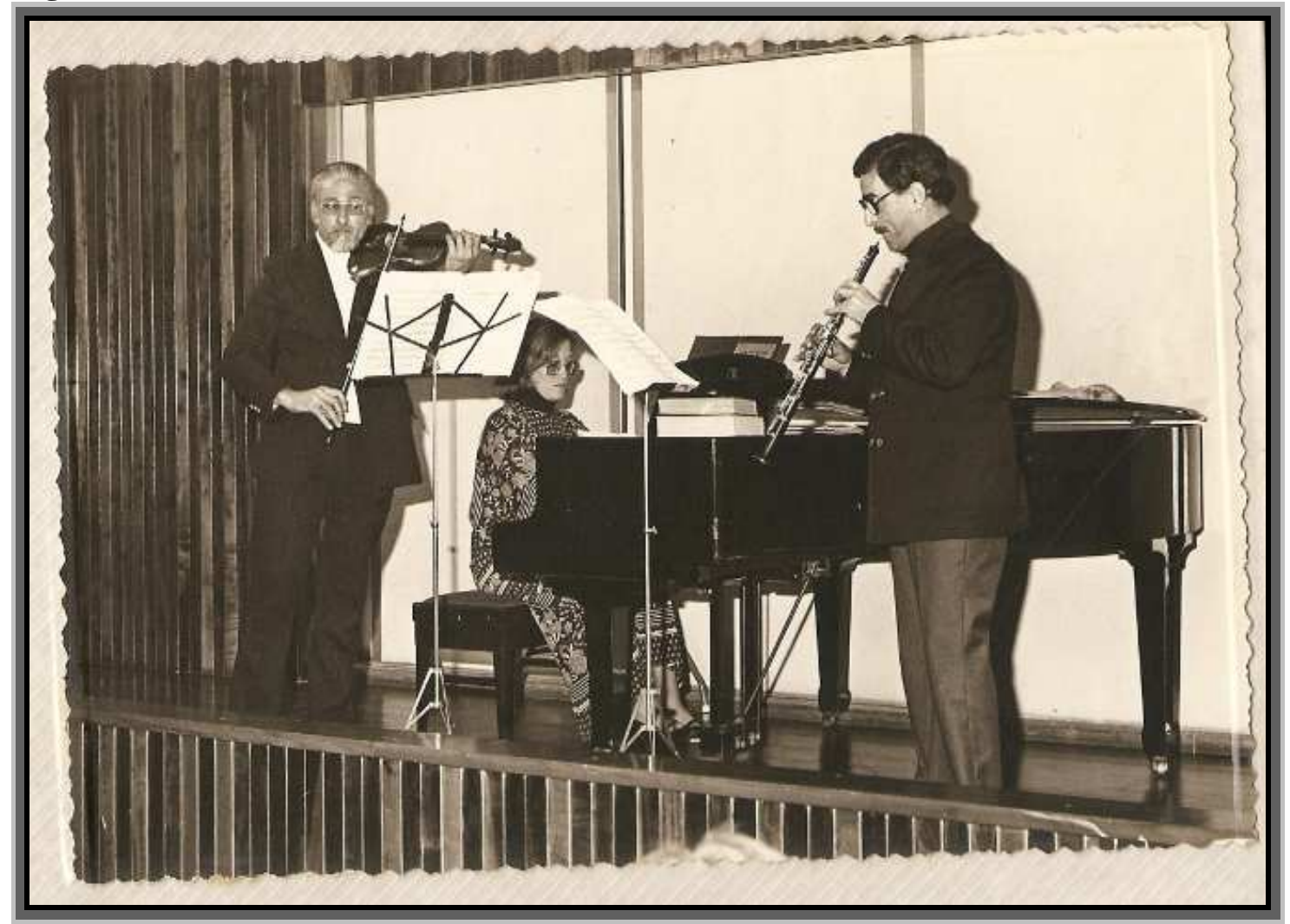

Fonte: Acervo do CDMCC. 
Figura 24 - Paulo Bosísio e Lílian Barreto, antes do término do teatro Procópio Ferreira.

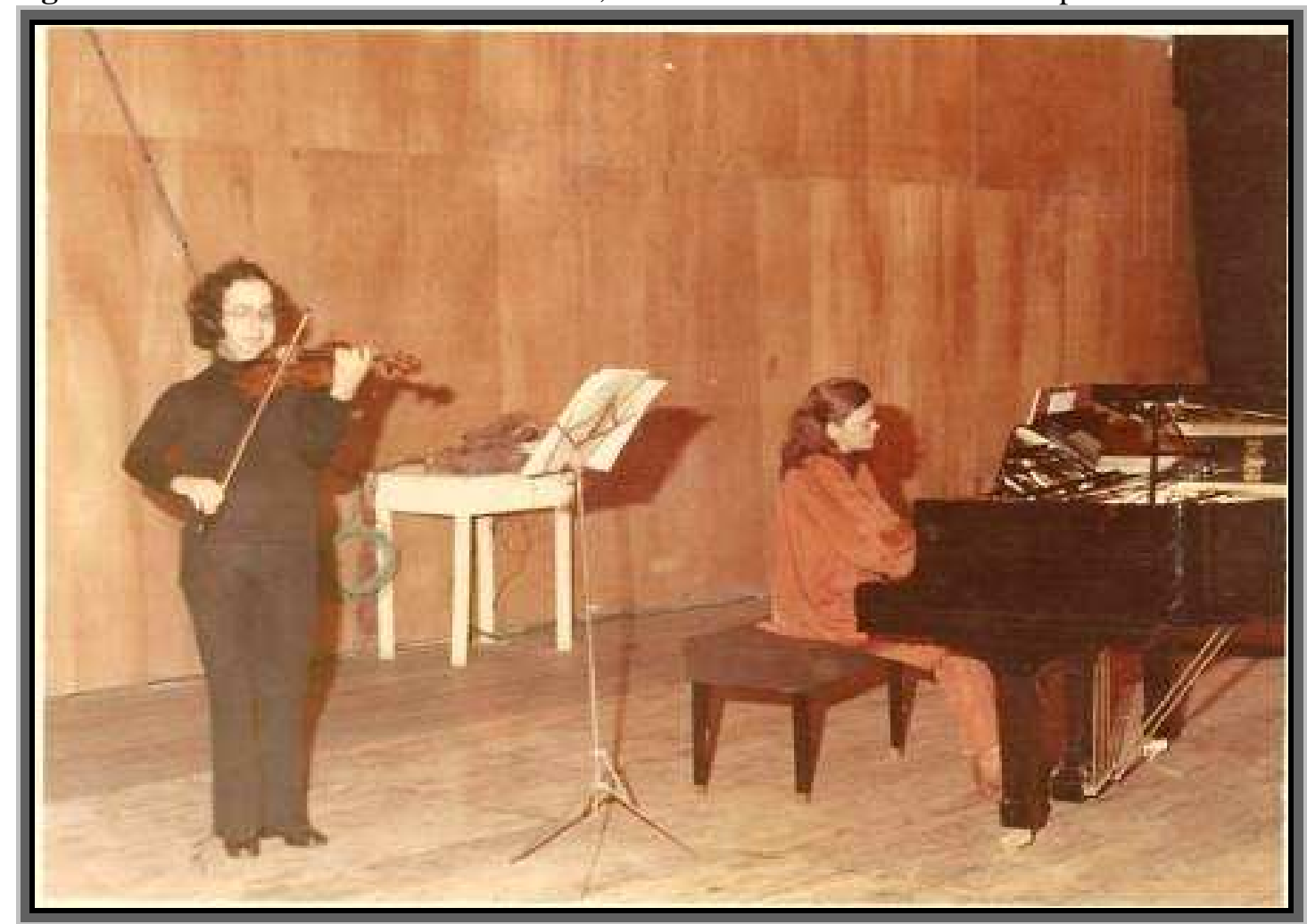

Fonte: Acervo do CDMCC.

Figura 25 - Guiomar Novaes

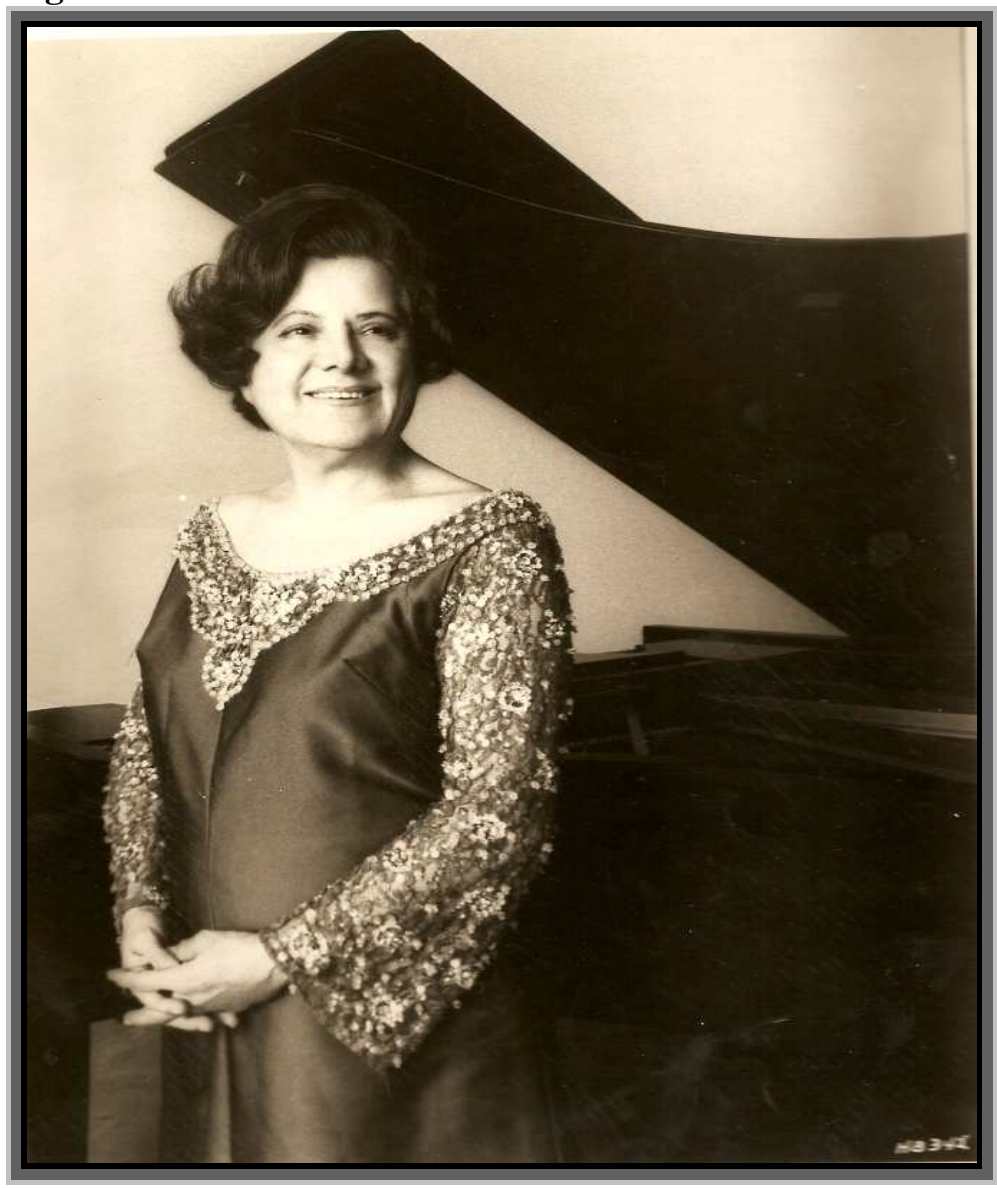

Fonte: Acervo do CDMCC 
Figura 26 - Lançamento do disco de João Carlos Martins.

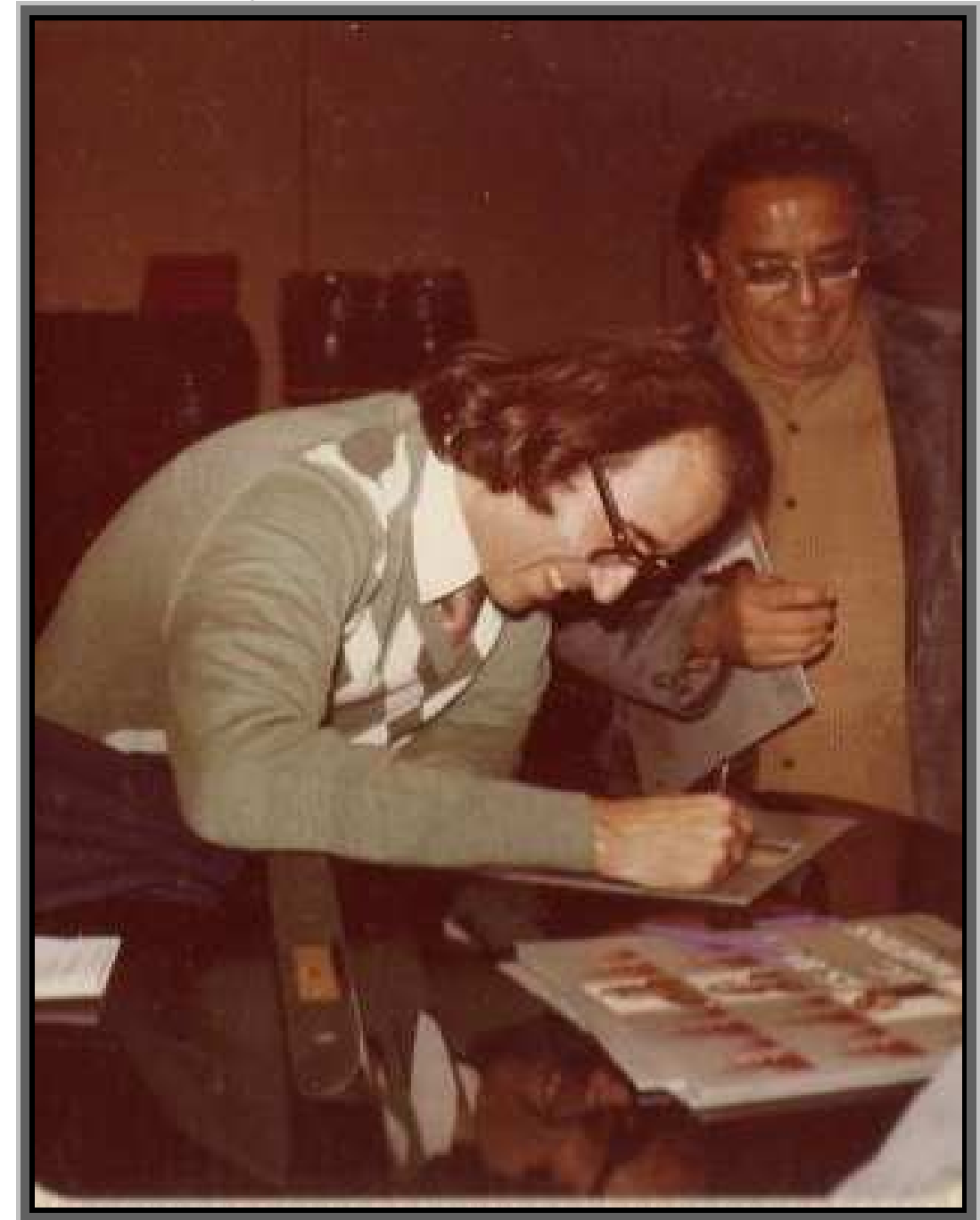

Fonte: Acervo do CDMCC.

Figura 27 - Amaral Vieira ao piano junto à orquestra do CDMCC.

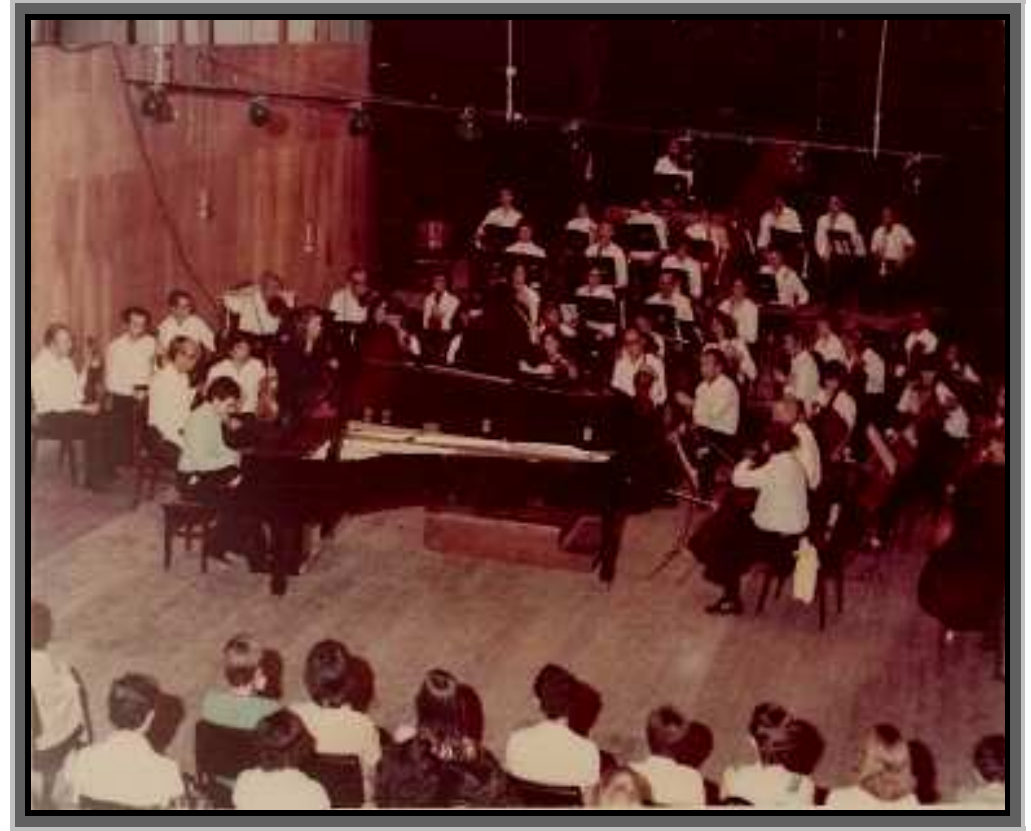

Fonte: Acervo do CDMCC. 
Em reunião Ordinária do CDMCC de Tatuí, ocorrida em 24/4/1969, no prédio localizado na Rua São Bento, $n^{\circ} .415$, o Sr. Diretor aborda sobre a importância dos alunos da instituição residentes em outras cidades, pois considera que seriam esses alunos que poderiam ampliar a atuação da escola a um âmbito regional, sonho que a cidade acalentava há muitos anos.

Figura 28 - Reprodução da Ata da $24^{a}$ Reunião Ordinária de 24/04/1969.

\begin{tabular}{|c|}
\hline 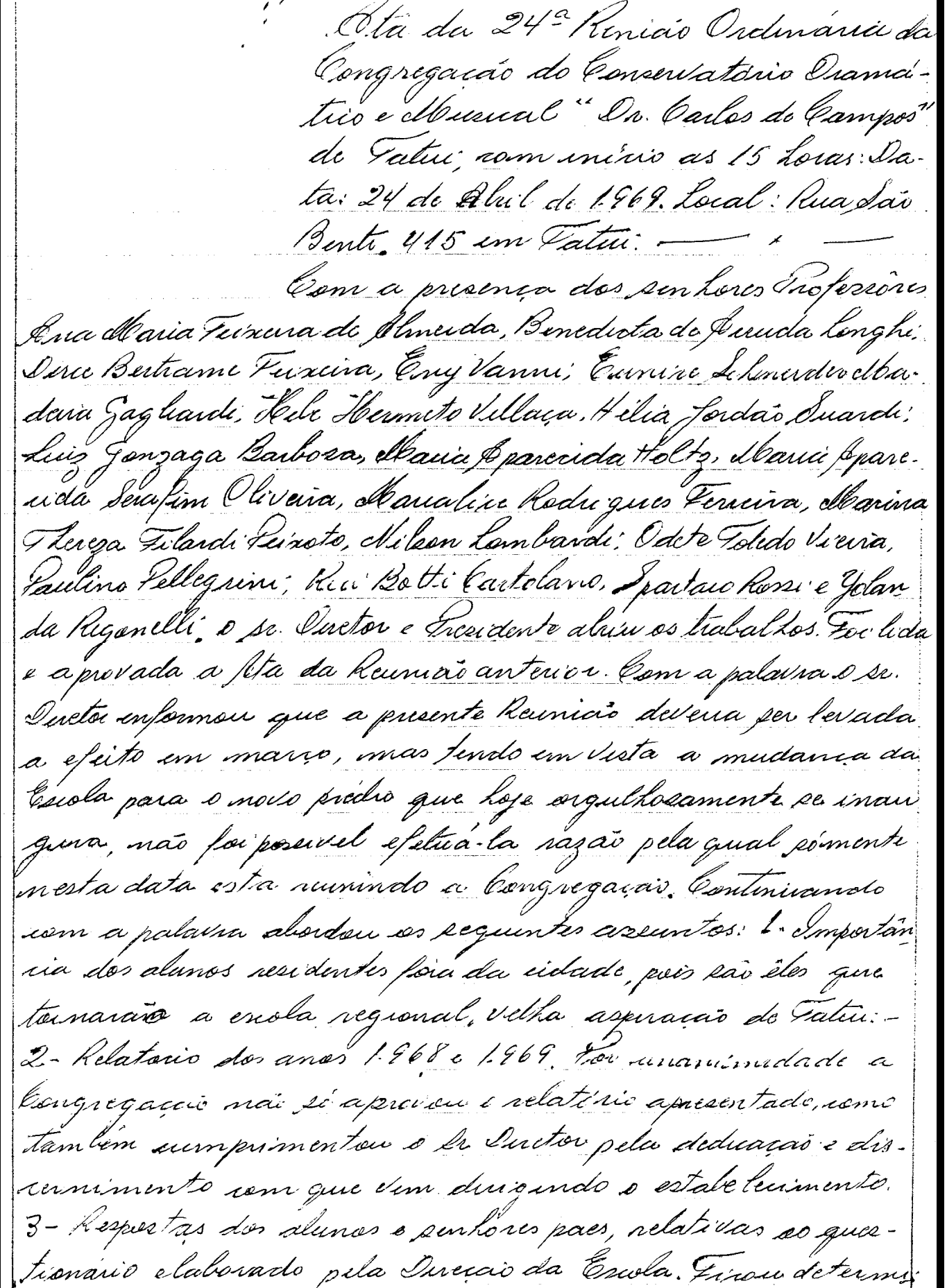 \\
\hline
\end{tabular}


madi que as respoitas serai ana legadas pela Congreqacaio

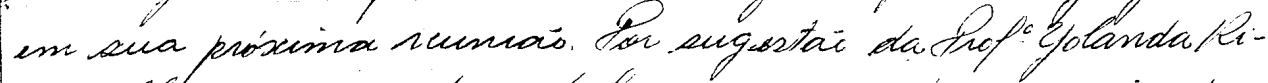

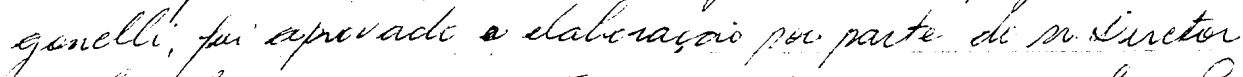
da Isicla de un quastionaivo deriyedo as pentores tro-

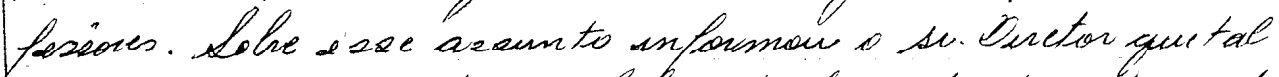
questronaivo fa estava elaborado, fieando de entrega-lot aos fenhores trolessores opor tunamen te; 4-Cndicacai do

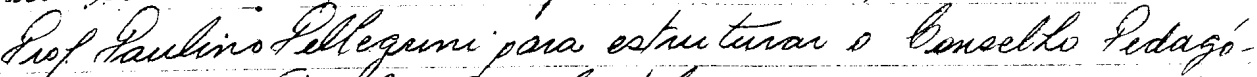
qieo, e do Rnof Rui Botti Cartolano, para suganizar os testes due municalidade. Bontonuando com a palaria o su. Live

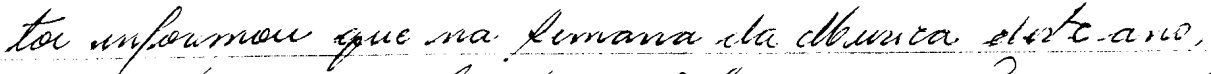

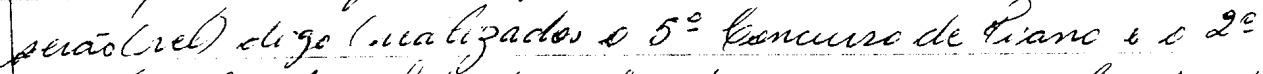

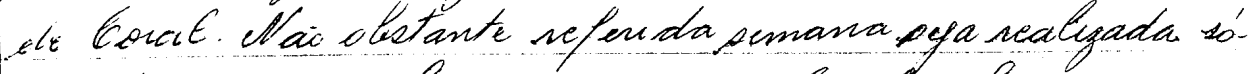
mente un novemho, a derecai da Ercola tovivera decidido denignar uma homessaí de Chofe zeóres pava com antecedencia, organizar toda a programacio selativa aquelas festivledades. O comizeai s'a fiquente: Penedicta

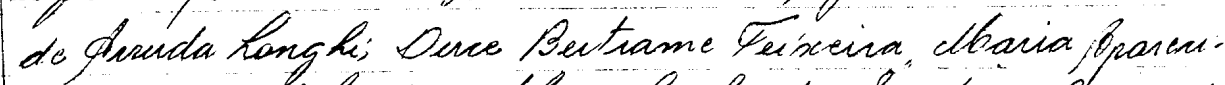

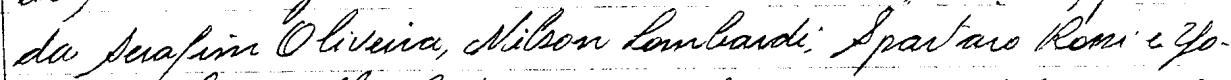

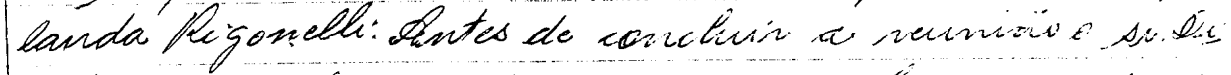

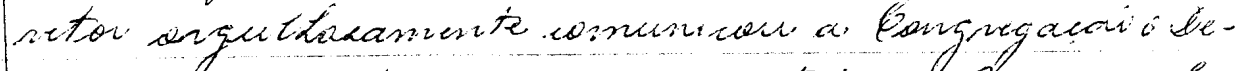

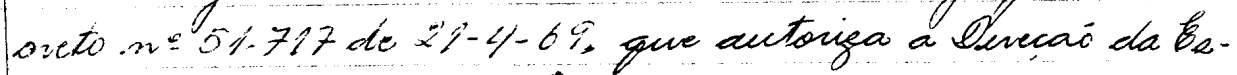
co la nos mo ldes da. Gi. F. a contratar profeszónes pora

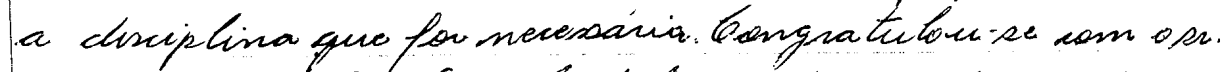
Deretor o prof Rei Solti tearto lane, afumando que tat ve. ereto abrivia novos Lou zontes para a Bus la. Bomo convida-

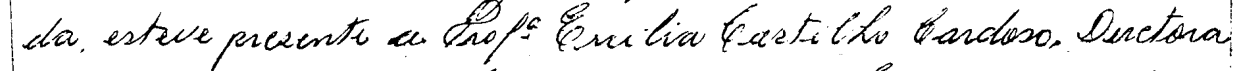

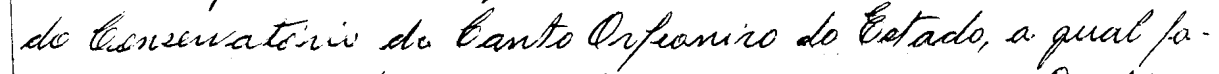

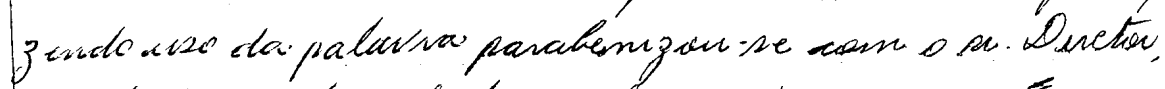
por tede gue tern fict en faver da muniva. Eomconars

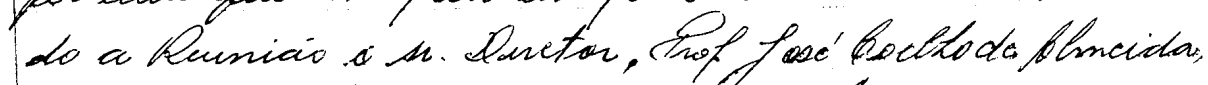
agradecen a todos a cooperaciai necelicla. propondo tam

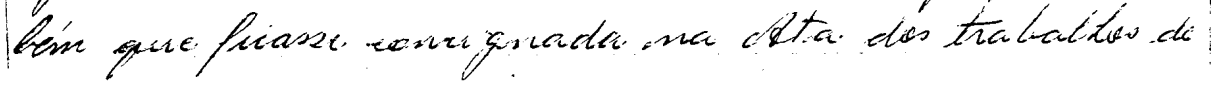




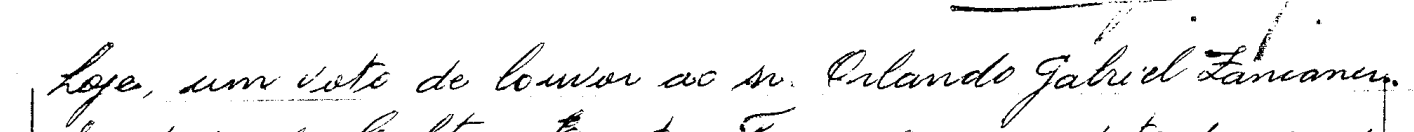

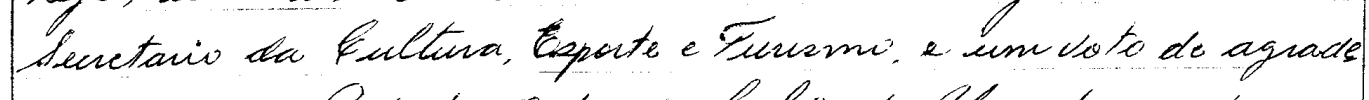

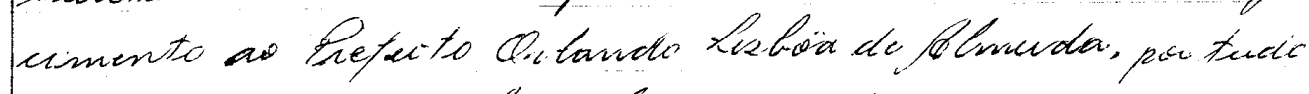

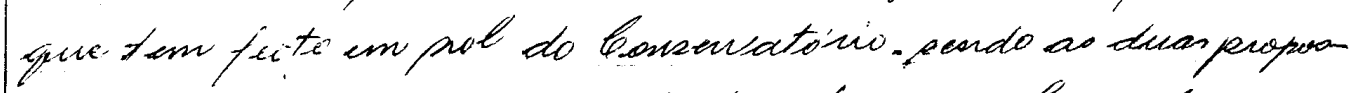
Tas aprovadar por unanimi dada. Na mais Lavendo a no-

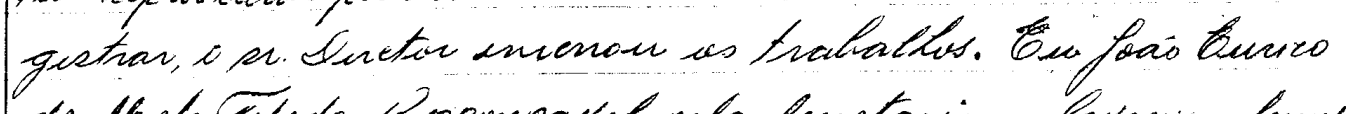

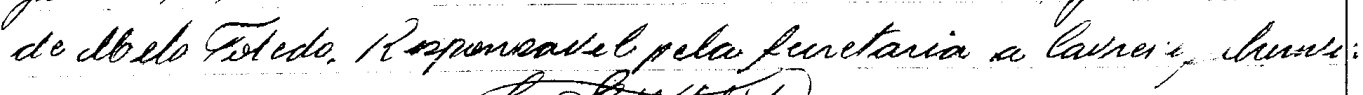

Helytmeida

Dévechita de pnude forgh.

Dirce Bertra me Deisceira

Eony elanimi

Emice If Gagliard.

blue Steruetsielacap

Sloffuaidi

tima fi Zarboza

mla Hatz

moseliveira

Marialice Rodriguestenenia

manno- thereza Leland Texcat

Lie Conch

Odete Toledo Pieira.

Dauninis telegunin.

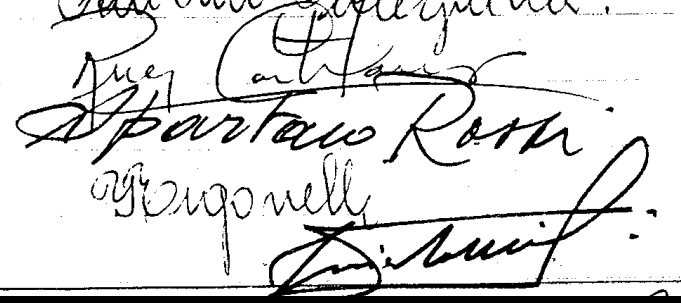

Fonte: Acervo do CDMCC de Tatuí.

71 
Em seis anos de trabalho este Diretor conseguiu praticamente triplicar o número de alunos de outras cidades, alcançando um número bastante expressivo, iniciando em 1968 com 100 alunos e em 1975 passando a atender 500 alunos vindos de outros municípios, como podemos observar no gráfico abaixo:

Figura 29 - Alunos matriculados de outros municípios de 1954 a 1975.

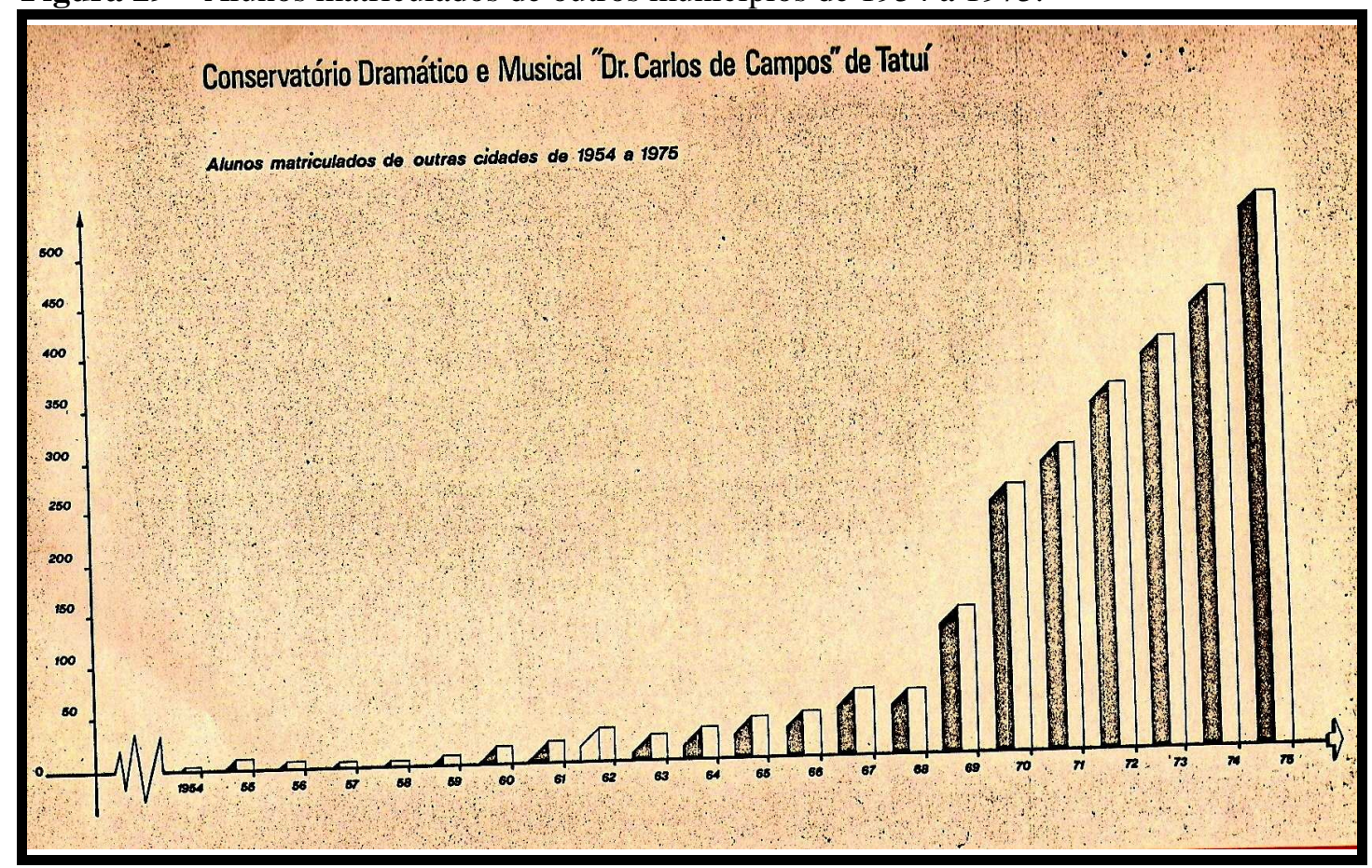

Fonte: Acervo do CDMCC de Tatuí.

Figura 30 - Total de alunos matriculados de 1954 a 1976.

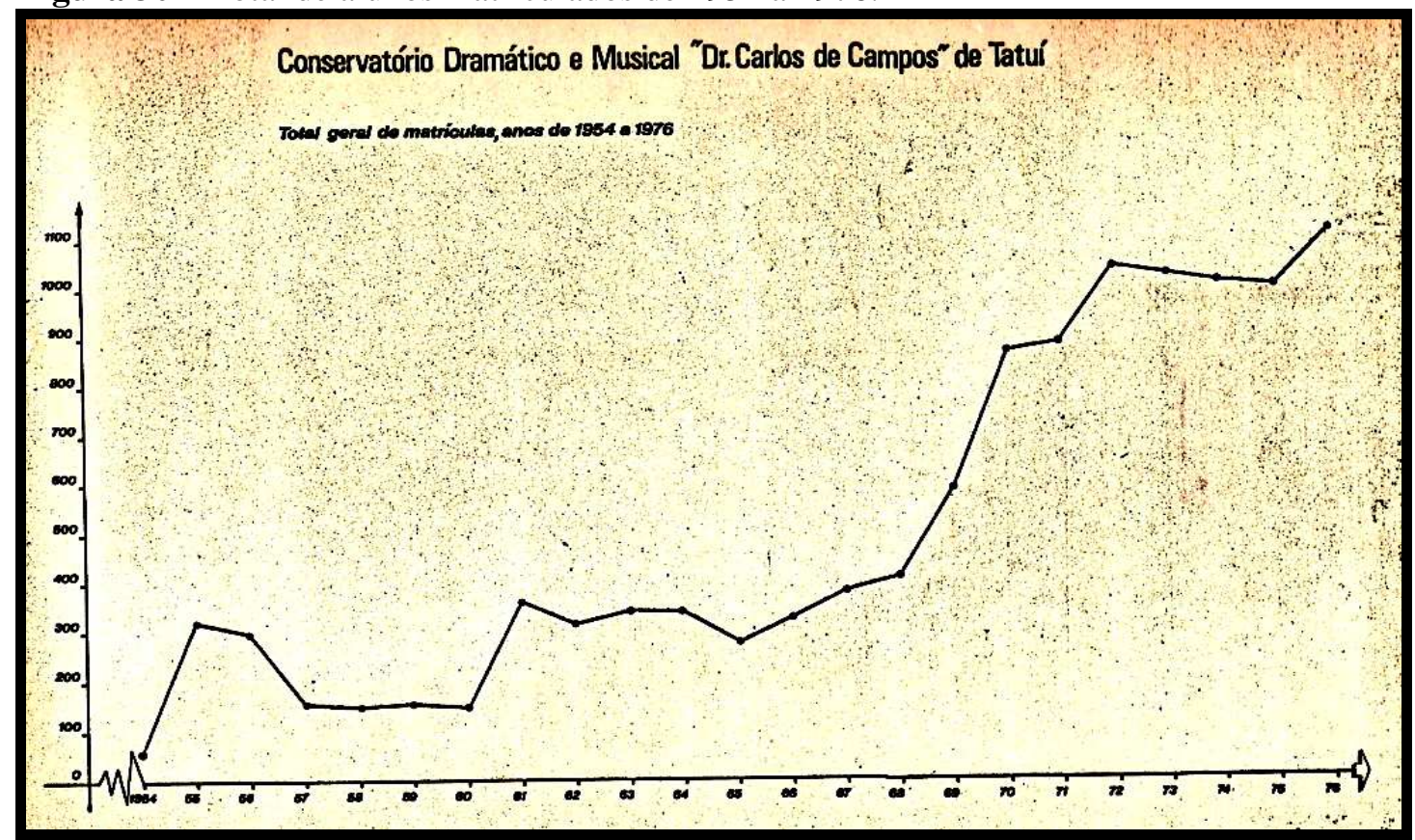

Fonte: Acervo do CDMCC de Tatuí. 
Em oito anos o CDMCC passou de 400 alunos para mais de um 1.181 alunos assim distribuídos:

\begin{tabular}{|c|c|c|c|c|c|c|c|}
\hline Violino & 31 & Harpa & 02 & Saxofone & 18 & Tuba & 02 \\
\hline Viola & 07 & Flauta & 40 & Fagote & 06 & $\begin{array}{c}\text { Tímpanos e } \\
\text { percussão }\end{array}$ & 38 \\
\hline Violoncelo & 15 & Flauta-Doce & 111 & Trompa & 05 & Piano & 398 \\
\hline Contrabaixo & 21 & Oboé & 09 & Trompete & 38 & Canto & 38 \\
\hline Violão & 231 & Clarineta & 40 & Trombone & 09 & $\begin{array}{l}\text { Iniciação } \\
\text { Musical }\end{array}$ & 120 \\
\hline
\end{tabular}

Das matrículas acima, 40,7\% são de alunos de Tatuí e 50,3\% correspondem a alunos provenientes de 39 cidades da região, inclusive da capital do Estado de São Paulo.

A década de 1970 foi o período mais intenso da ditadura militar, que não havia começado e nem iria terminar naqueles anos. Apesar disso, o Brasil vivia um período de crescimento econômico, as multinacionais investiam no Brasil do "milagre econômico" que pode ser definido como sendo:

"O que se convencionou chamar de "milagre" tinha a sustentá-lo três pilares básicos: o aprofundamento da exploração da classe trabalhadora submetida ao arrocho salarial, às mais duras condições de trabalho e à repressão política; a ação do Estado garantindo a expansão capitalista e a consolidação do grande capital nacional e internacional; e a entrada maciça de capitais estrangeiros na forma de investimentos e de empréstimos". (Nadine Habert, 1996: 13,14).

José Coelho de Almeida sempre foi um homem à frente de seu tempo, dominado por um pensamento visionário e de conceito rigoroso, é assim que muitos dos professores que ainda lecionam na escola o descrevem. 
No ano de 1970 é iniciada a construção do auditório da escola localizado ao lado do CDMCC de Tatuí, com o apoio do Secretário da Cultura, Esporte e Turismo, Orlando Gabriel Zancaner, e do prefeito de Tatuí, Engenheiro Orlando Lisboa de Almeida. José Coelho de Almeida fazia viagens semanais para resolver problemas referentes à construção do auditório.

O Teatro Procópio Ferreira, como viria a ser chamado, projeto bastante audacioso dentro deste contexto sócio-político, previa a construção de um auditório com mais de 2200 metros quadrados de construção, com platéia para 600 pessoas, um palco com 300 metros quadrados, incluindo um fosso para apresentações de óperas, todos os aparatos para apresentações teatrais e líricas, salas para musica eletrônica, 04 camarins individuais e 02 coletivos; algo bastante incomum para a época e principalmente no interior de São Paulo.

Figura 31 - Maquete do auditório, 1970. Atualmente Teatro Procópio Ferreira em Tatuí.

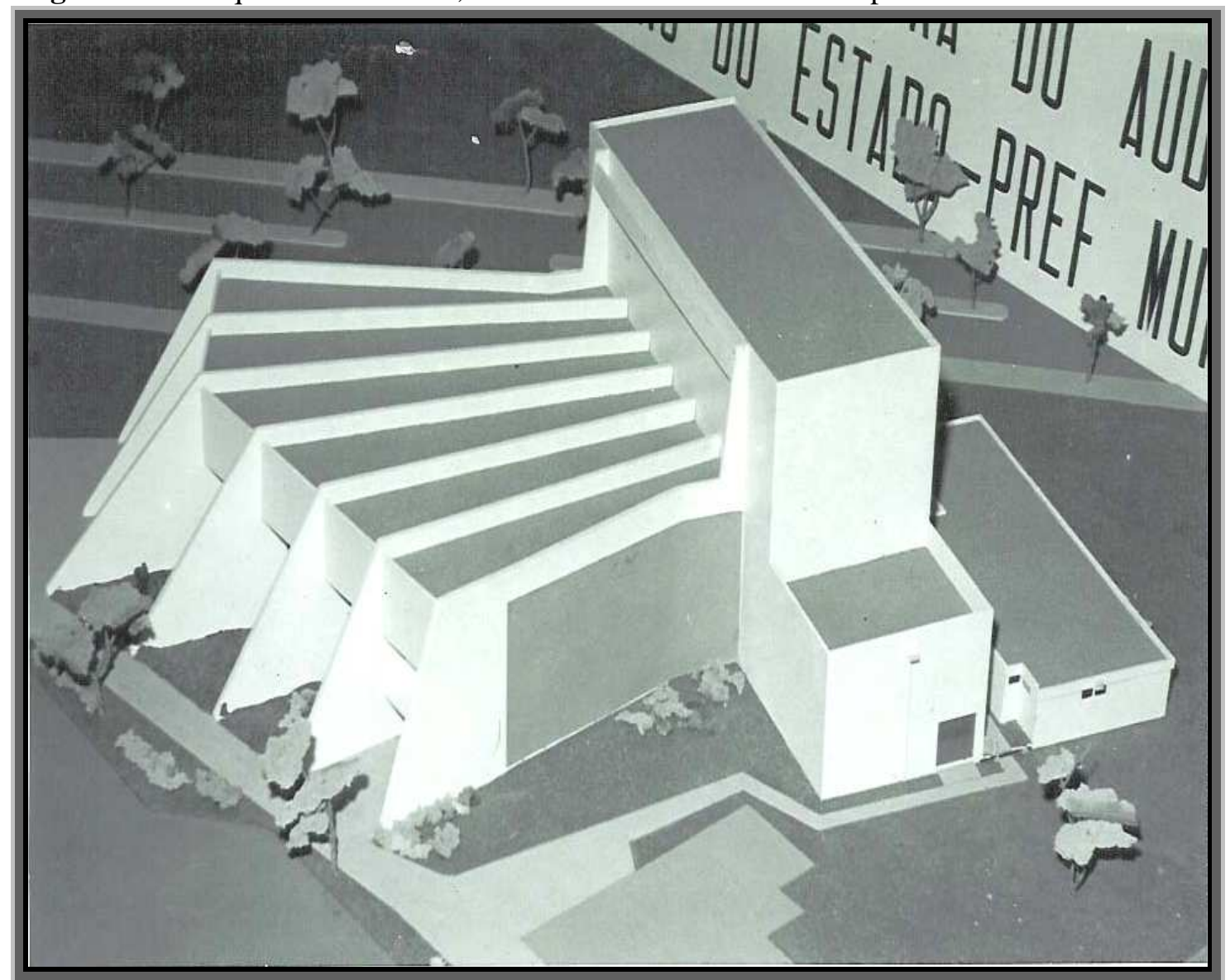

Fonte: Acervo do CDMCC de Tatuí. 
Figura 32 - Ata da assinatura de construção do teatro em 20 de maio de 1970.

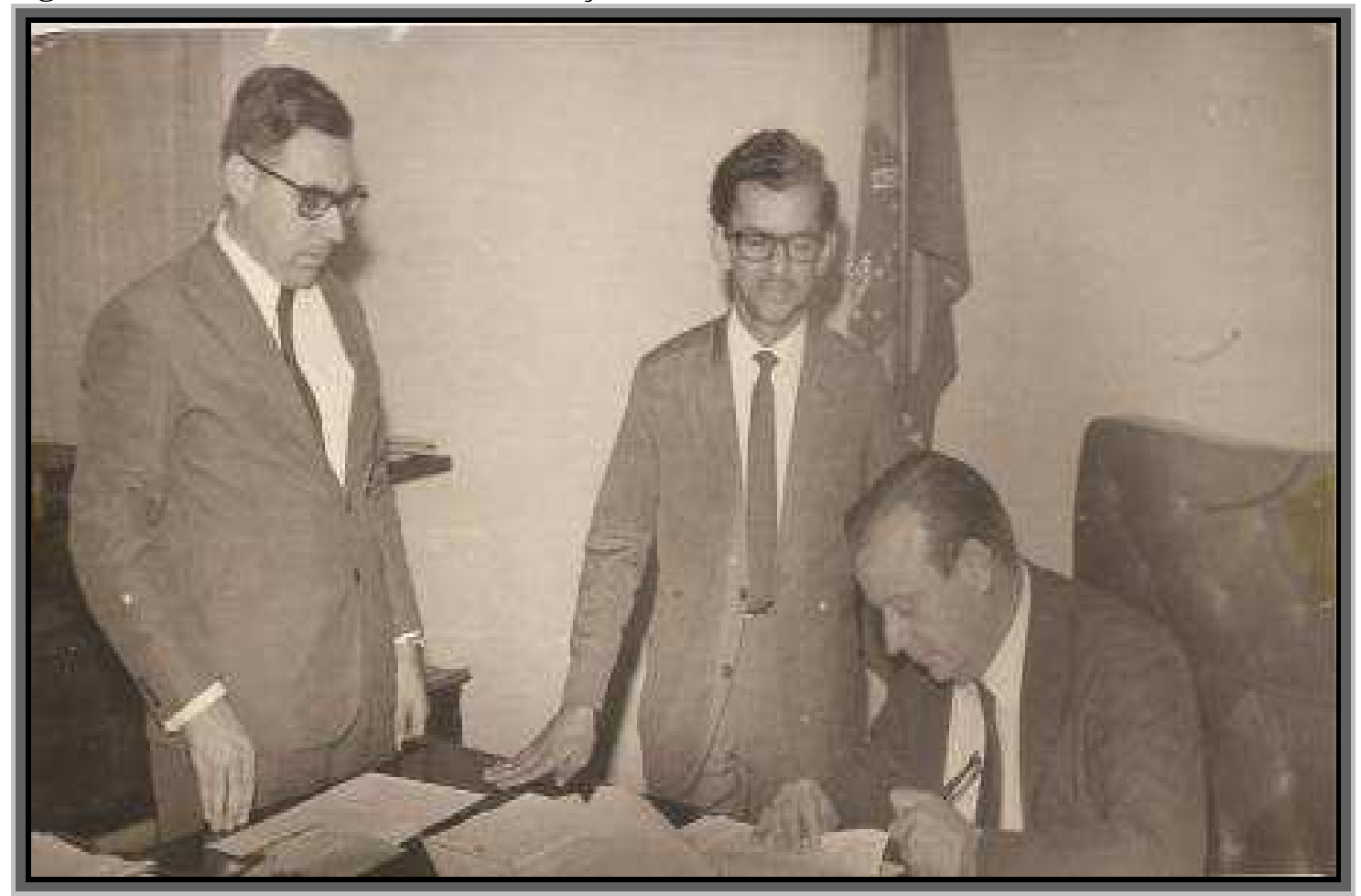

Fonte: Acervo do CDMCC de Tatuí.

Figura 33 - Preparação do terreno para a construção do teatro.

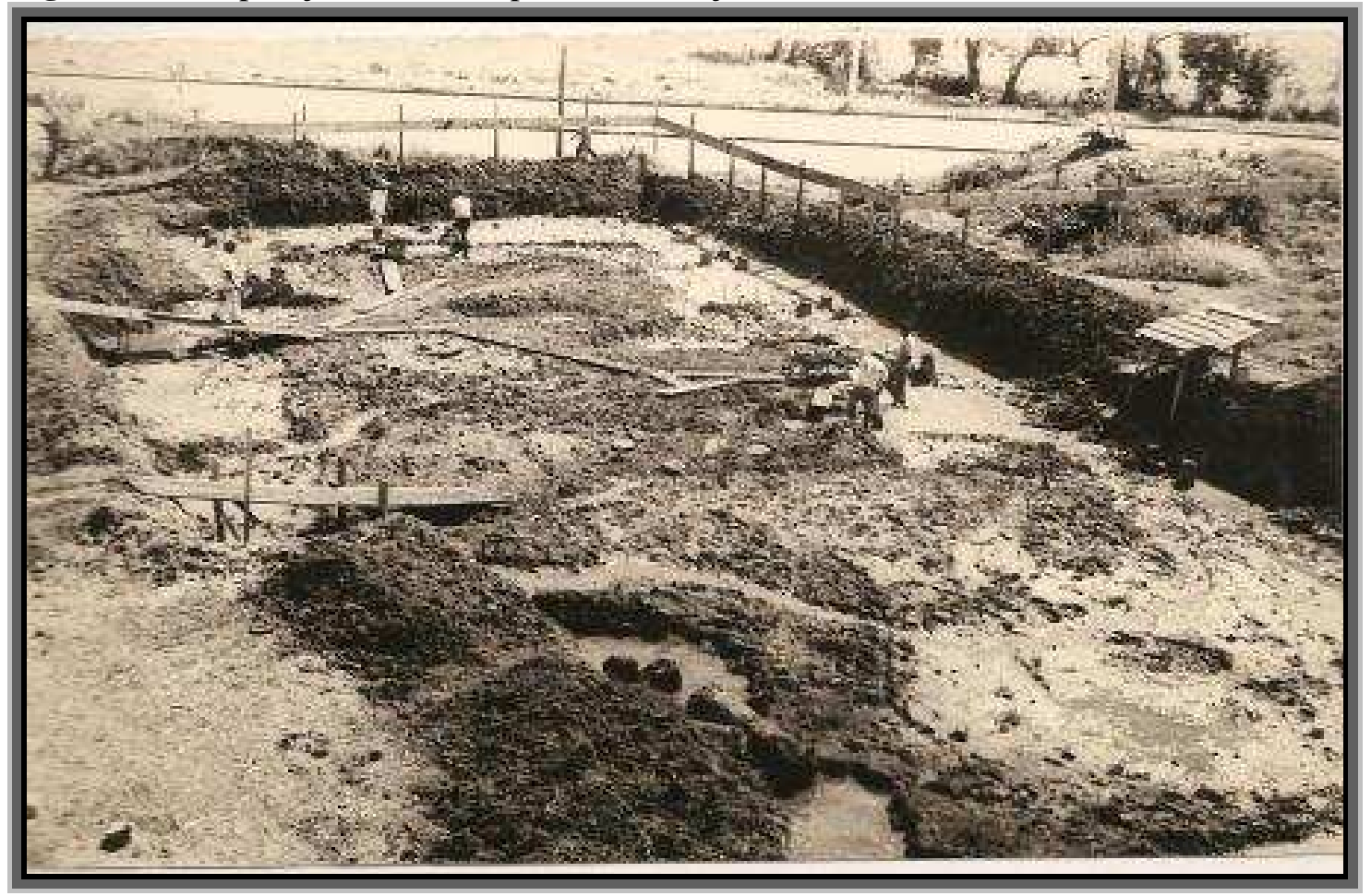

Fonte: Acervo do CDMCC de Tatuí. 
Figura 34 - Parte interna do teatro em construção.

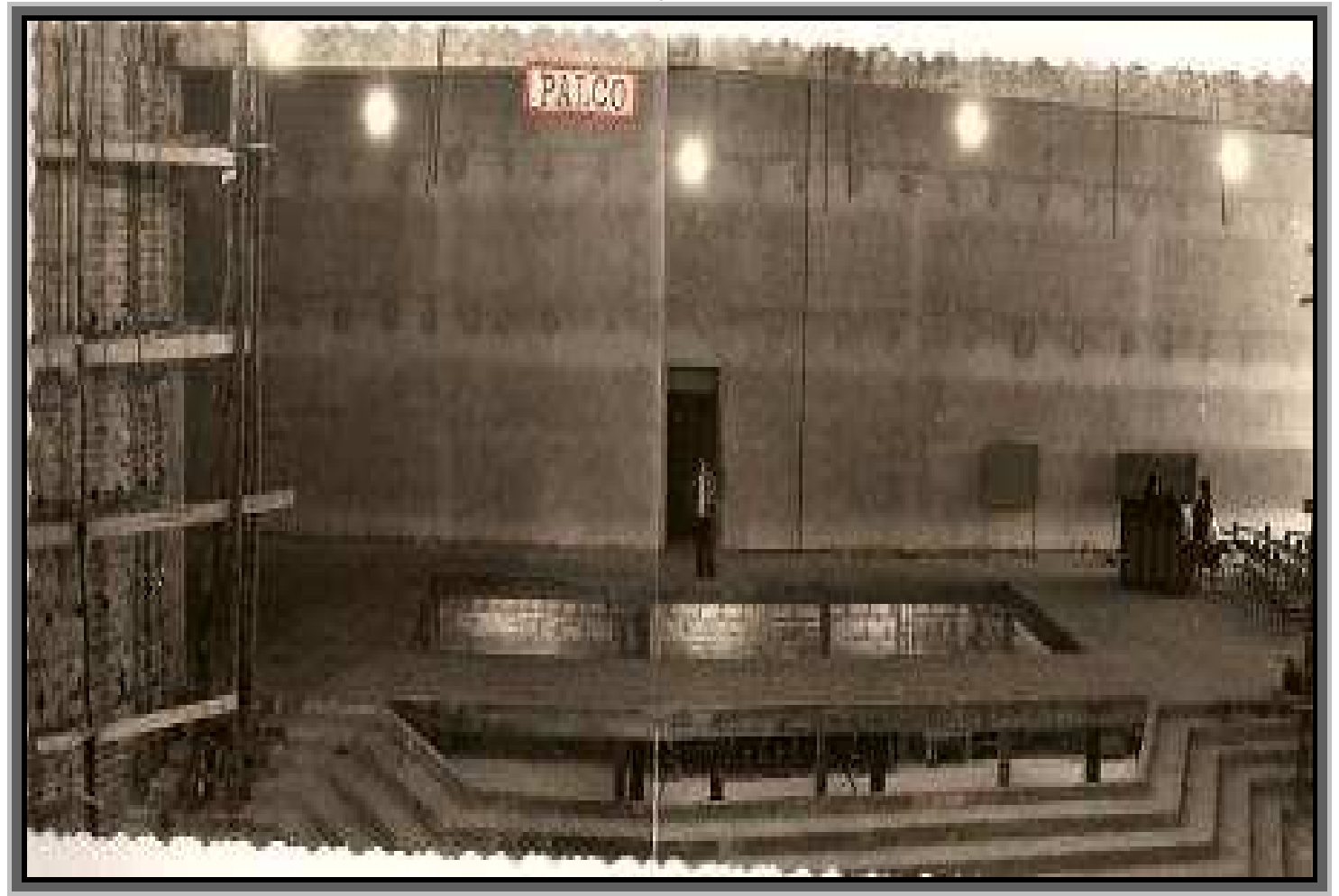

Fonte: Acervo do CDMCC de Tatuí.

Figura 35 - Parte interna do teatro terminado.

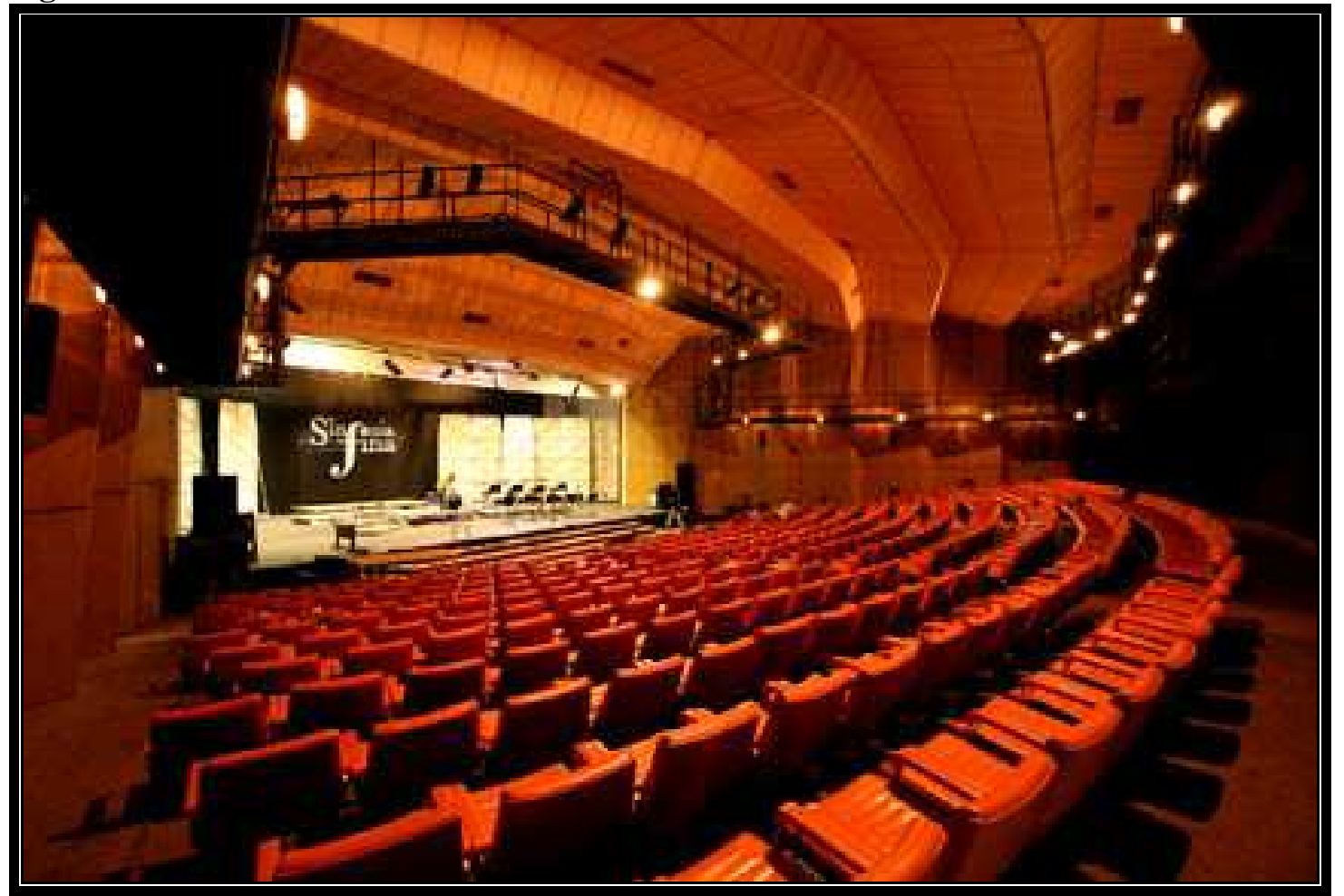

Fonte: Acervo do CDMCC de Tatuí. 
Figura 36 - Parte externa do teatro.

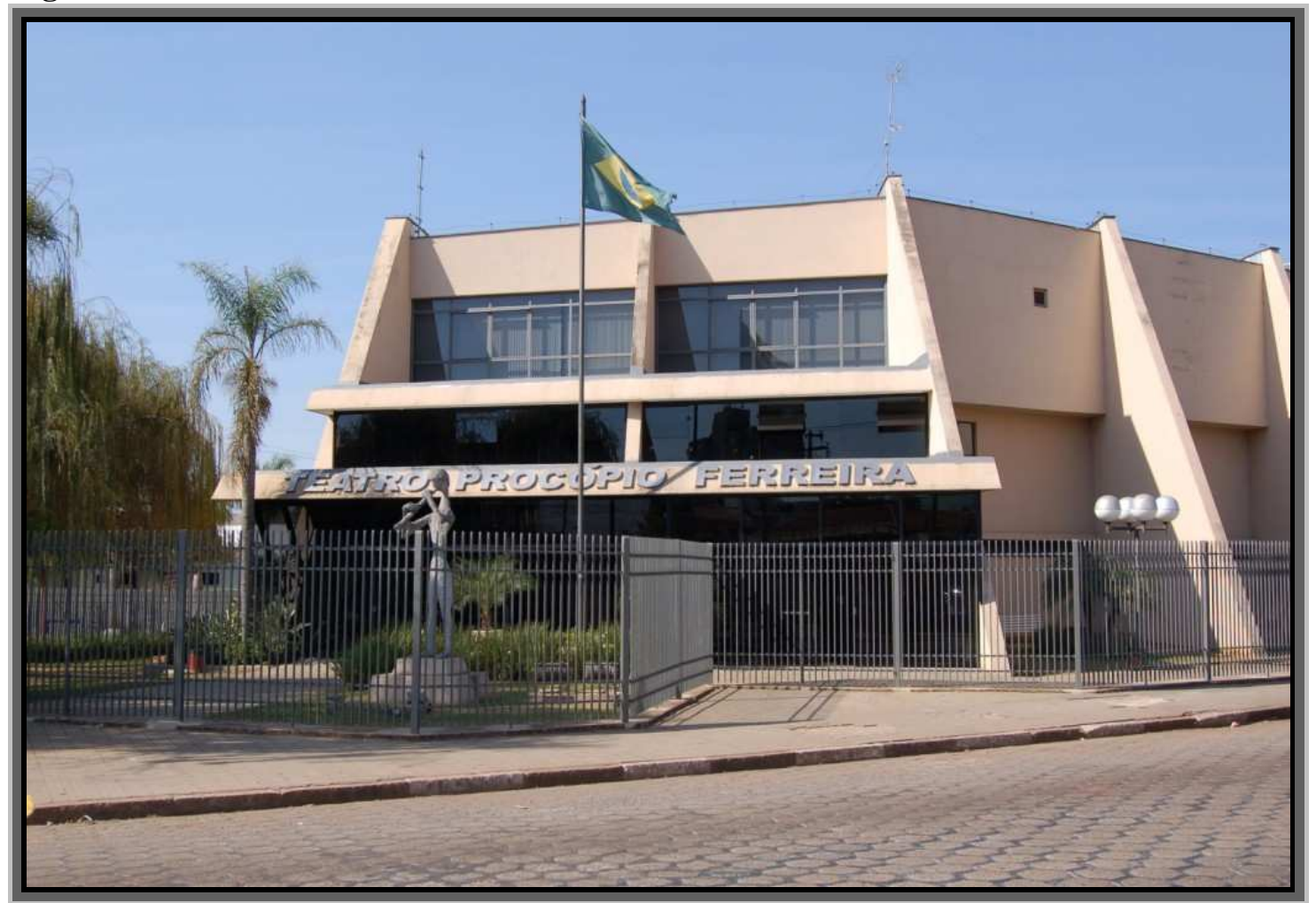

Fonte: Acervo do CDMCC de Tatuí

Em 1970, a escola contou com 871 alunos, o que necessitou estipular o número de vagas nos cursos de violão e piano, mesmo contando com a colaboração do pianista João Carlos Martins que, a convite do diretor José Coelho de Almeida, ministrou palestras sobre o estudo de piano e a execução de exercícios e peças para demonstrações práticas aos alunos do CDMCC de Tatuí.

Publicado no Diário Oficial de sábado, 06 de março de 1971, tendo como Governador do Estado de São Paulo, Roberto Costa de Abreu Sodré, e como Secretário de Cultura, Esportes e Turismo, Paulo Marcondes Pestana, é publicado o decreto no 52.687 de 05 de março de 1971, que dispõe sobre o novo regulamento do Conservatório Dramático e Musical "Dr. Carlos de Campos" de Tatuí , o qual prevalece até os dias de hoje. O quadro de professores do CDMCC de Tatuí aumenta, e pela primeira vez começa-se a discutir sobre um projeto político pedagógico para a escola.

Os cursos ficaram assim estabelecidos: piano, violino, viola, violoncelo, contrabaixo, harpa, violão, flauta, oboé, clarineta, fagote, trompa, trompete, trombone, tímpanos percussão e acessórios, canto, e bailado.

\footnotetext{
${ }^{9}$ Relatório na íntegra do regulamento do CDMCC, anexo c, pág.138.
} 
Cursos facultativos: Iniciação musical, curso preparatório, aperfeiçoamento, composição e regência.

Juntamente com o instrumento, eram ministradas aulas das seguintes disciplinas complementares: teoria e solfejo (percepção musical), coral, análise musical elementar, analise musical, história da música e apreciação musical, biologia aplicada e acústica, folclore musical, psicologia aplicada e pedagogia, pratica de orquestra e musica de câmara.

Nesse período muitos alunos conseguiram bolsas de estudos em outros países através da boa formação instrumental adquirida no CDMCC, dentre esses, podemos citar alguns exemplos: Ana Valéria Poles, nasceu em Tatuí, e começou a estudar contrabaixo aos 12 anos na classe do professor Nikolaus Schevistschenko, no CDMCC, formando-se em 1981. Após vencer importantes prêmios nacionais e tocar como solista com importantes orquestras brasileiras, foi para a Áustria em 1982, como bolsista do Governo do Estado de São Paulo, para estudar na Academia de Música de Viena com o professor Ludwig Streicher.

O premiado trompista Luiz Garcia, também tatuiano, iniciou seus estudos musicais no Conservatório de Tatuí em 1981 com nove anos de idade, sob orientação de Daniel Havens e Mario Rocha, foi premiado em vários concursos, dentre eles o Concurso Sul América e o Premio Eldorado. Na década de 90,Luiz parte para Nova York para ingressar na conceituada escola de musica Juilliard School, transferindo-se mais tarde para o New England Conservatory em Boston onde concluiu seu bacharelado em performance com "distinçao" na classe do Prof. Charles Kavalovski. Durante dois anos integrou o famoso Empire Brass. Atuou em grandes orquestras tais como a Filarmônica de Berlim, Sinfônica da Radio da Baviera, Staatskapelle Berlim, Sinfônica da Radio Sueca, Sinfônica da Radio de Colônia, Mahler Chamber, Boston Symphony Orchestra dentre outras. 
Figura 37 - Recital de Valéria Poles e Aldo Vilani.

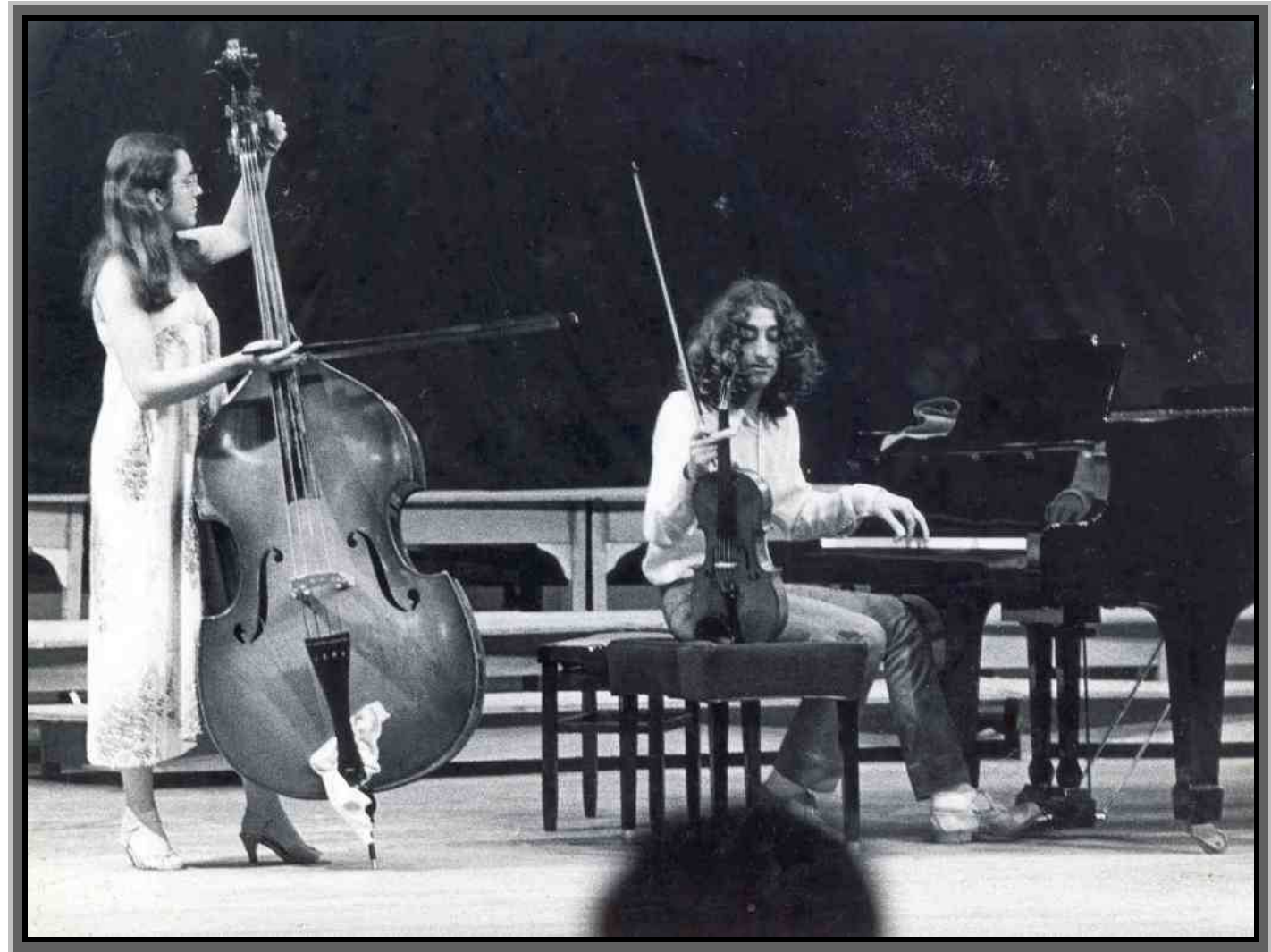

Fonte: Acervo do CDMCC de Tatuí.

Figura 38 - Luiz Garcia.

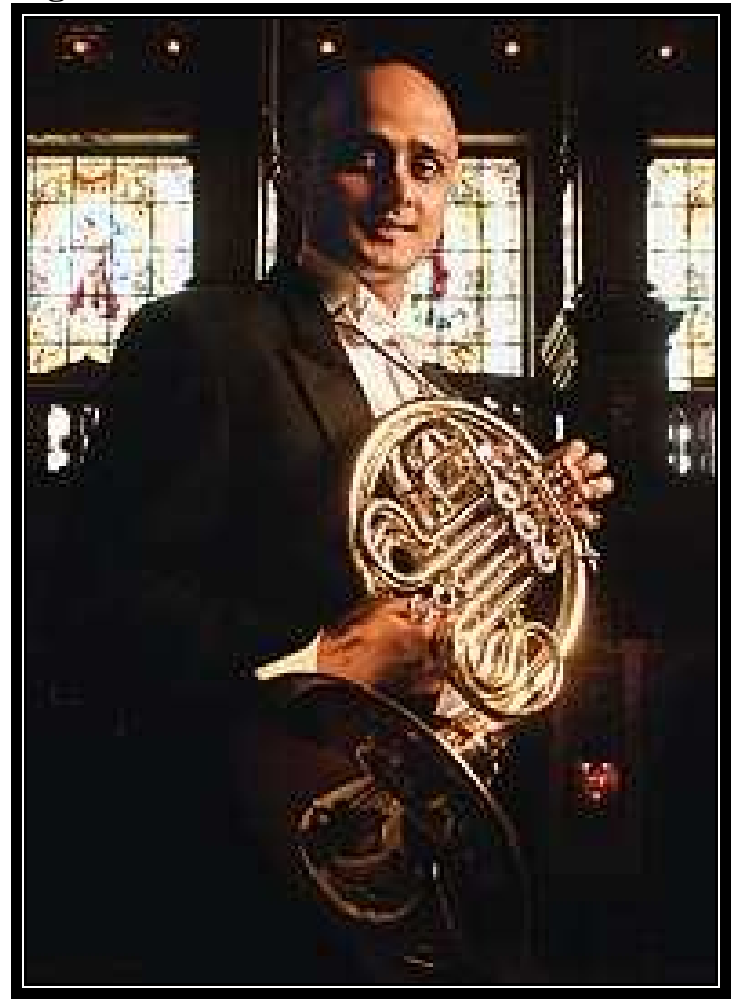

Fonte: INTERNET. 
Figura 39 - O violonista Édson Lopes recebendo diploma de formatura pelas mãos do Diretor José Coelho de Almeida.

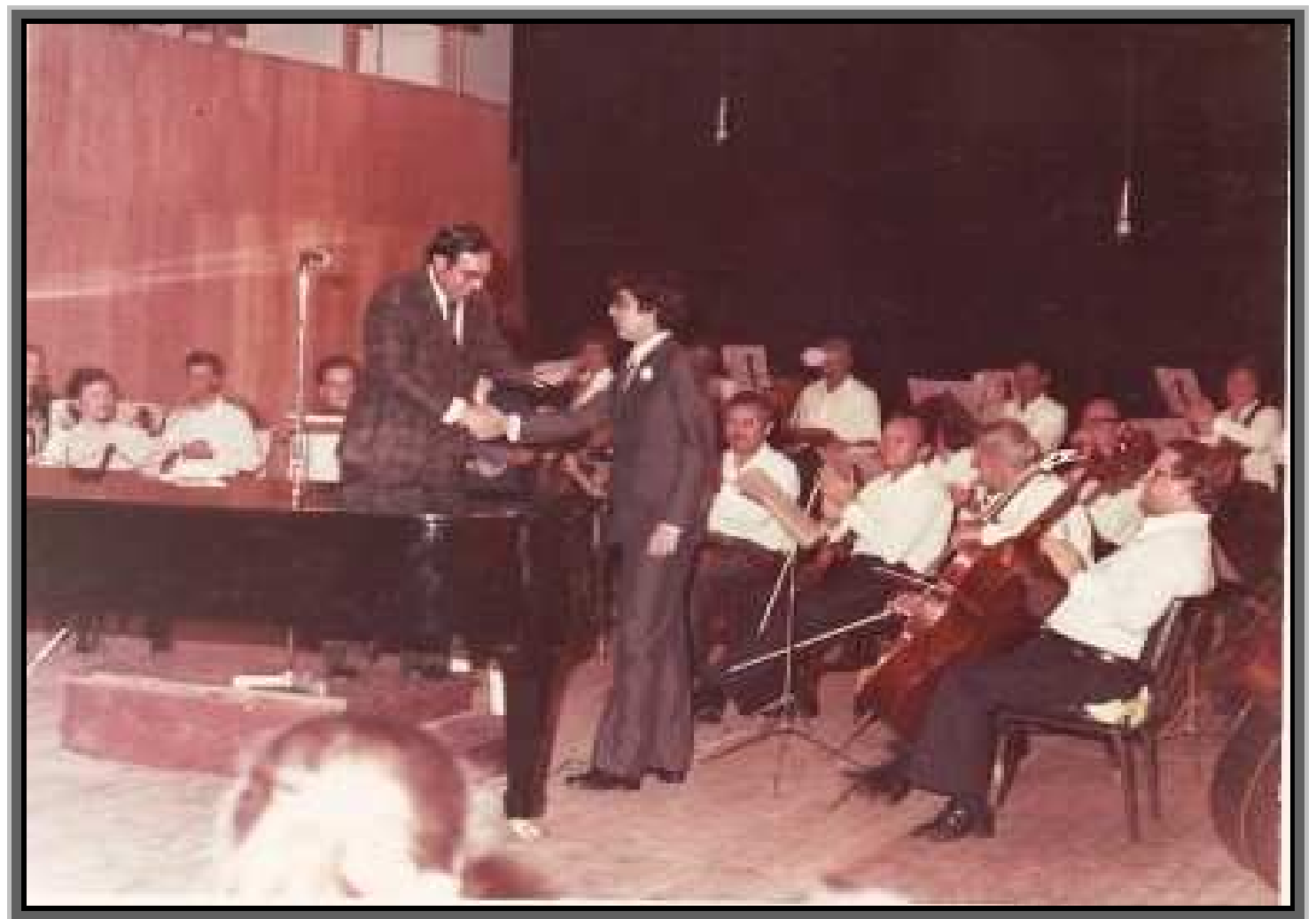

Fonte: Acervo do CDMCC de Tatuí.

Figura 40 - Matéria do Jornal "Sentinel" de Nashville de 10/05/1973 sobre a visita do prefeito de Nashville, EUA ao CDMCC de Tatuí, Bob Beckmeyer ao lado do prefeito de Tatuí, Paulo Ribeiro.

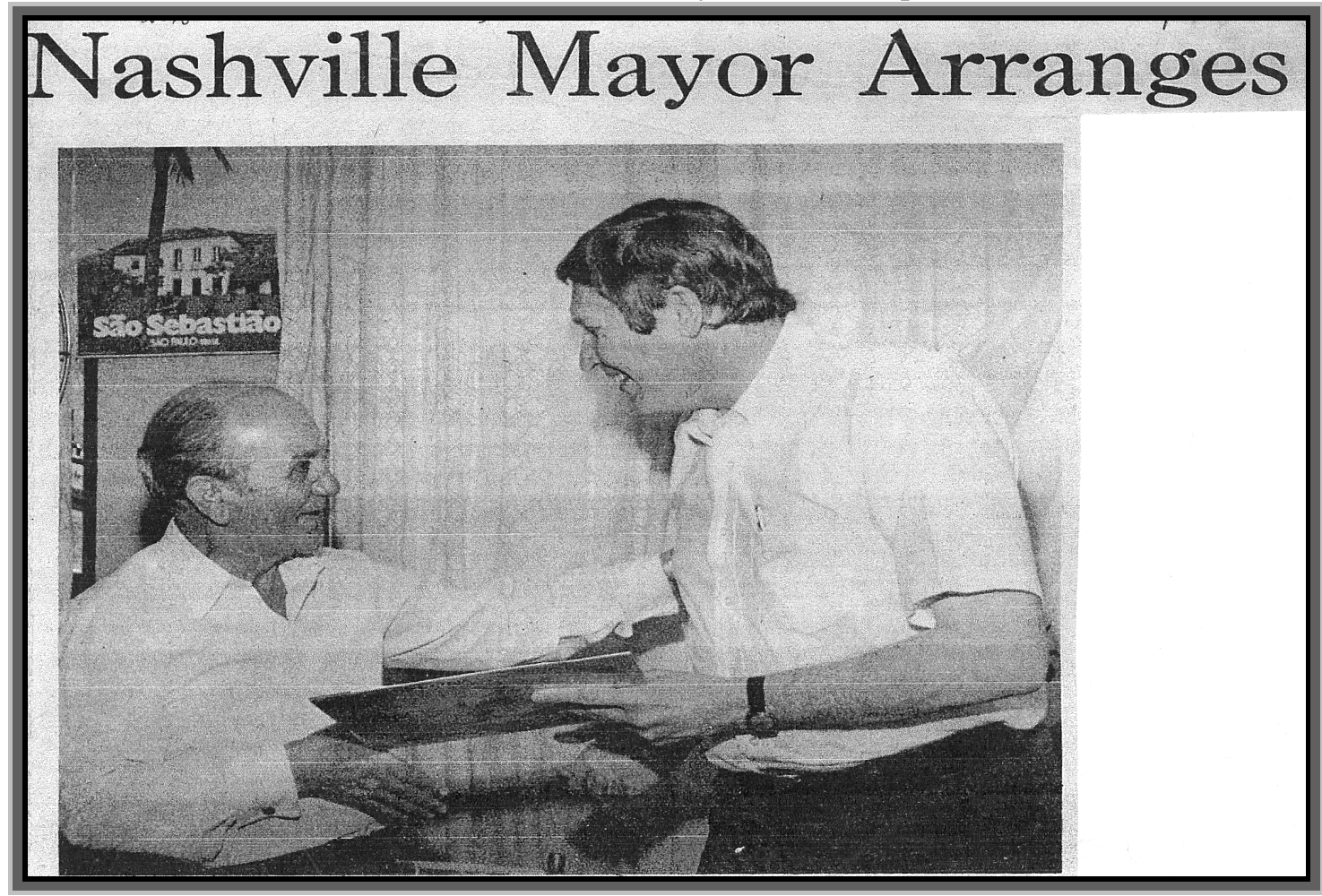

Fonte: Acervo próprio. 
Figura 41 - O prefeito Bob Beckmeyer, de Nashville, EUA no CDMCC de Tatuí.

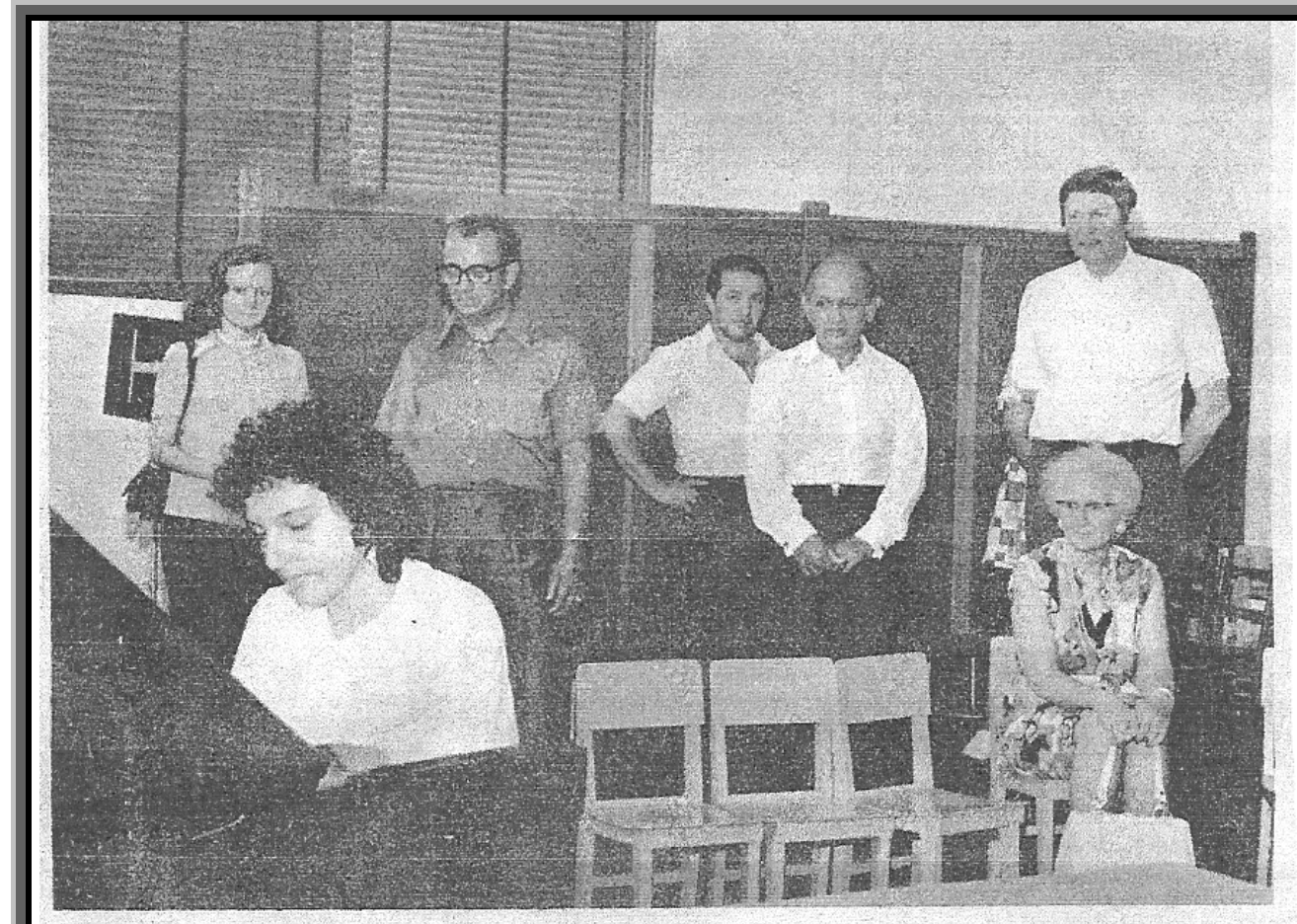

AT THE TATUI MUSIC CONSERVATORY-The female music student at the piano provided some music for the mayor of Tatui, Sao Paulo, Brazil, and his guest, Nashville mayor, Bob Beckmeyer, when Beckmeyer was in Brazil last month. Tatui and Nashville will become sister eities in an exchange of ideas, friendship and -maybe-people. The conservatory is one of the cultural and educational attraction of Tatui, a cily of almost 40,000 . Beckmeyer is standing at right, behind the woman who is seated.

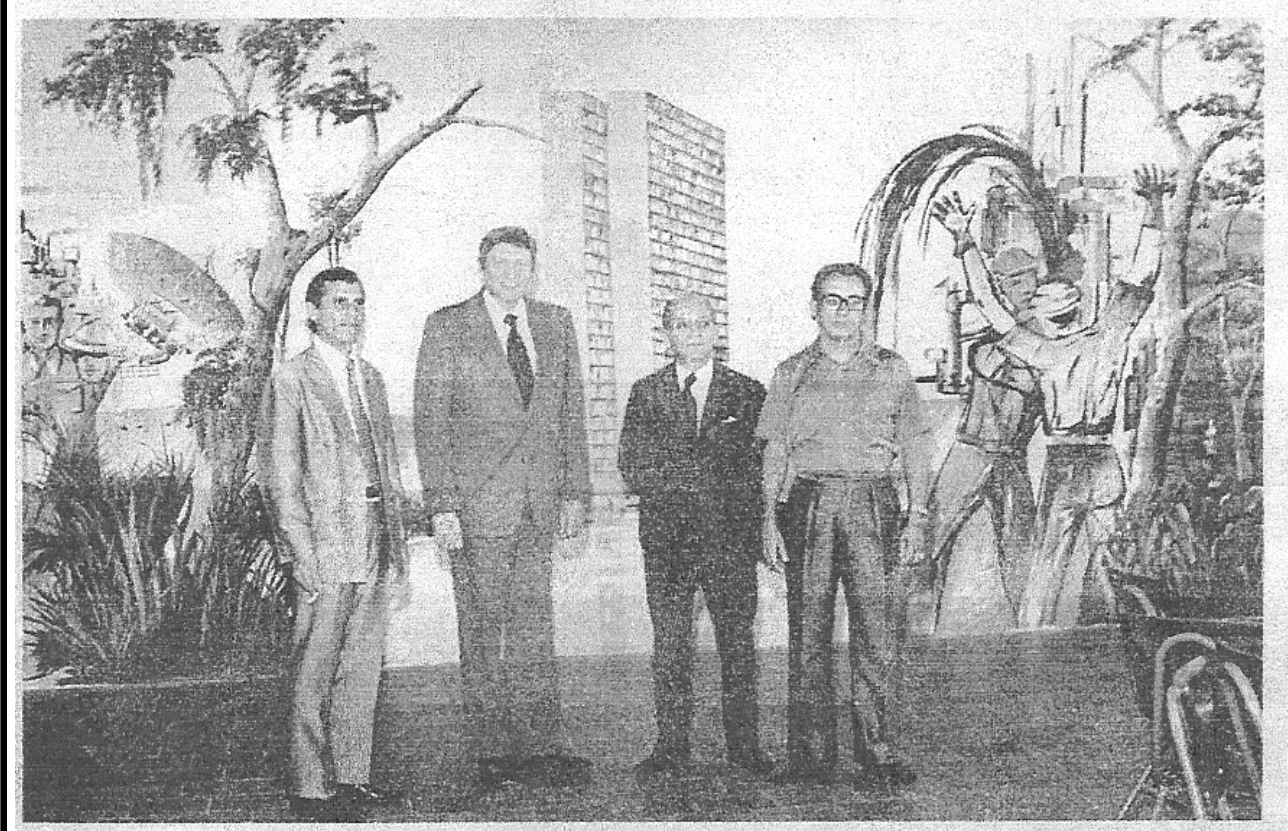

VIEWING BRAZILIAN ART WORK-Nashville Mayor Bob Beckmeyer toured the school in Tatui, Sao Paulo, where Brazilian students had decorated the walls with large murals. He was impressed with Brazilian arts and erafts and the overall technology of the Brazilian people. At right, a gusher spews sil-an event the Nashville area experienced recently when a gusher came in west of Nashville in the recently developed oilfield.

Fonte: Acervo próprio. 
Em 1975, o CDMCC de Tatuí participa, com bolsistas da escola no Festival de Inverno Campos do Jordão, os cursos eram de Clarineta, Música de Câmara e Regência Professor Jost Michaels, da Alemanha; Viola e Música de Câmara - Professor Luigi Alberto Bianchi, da Itália e Música e Ciência - Professor Michel Philippot, da França.

Figura 42 - I Festival de Jazz em São Paulo, 1976.

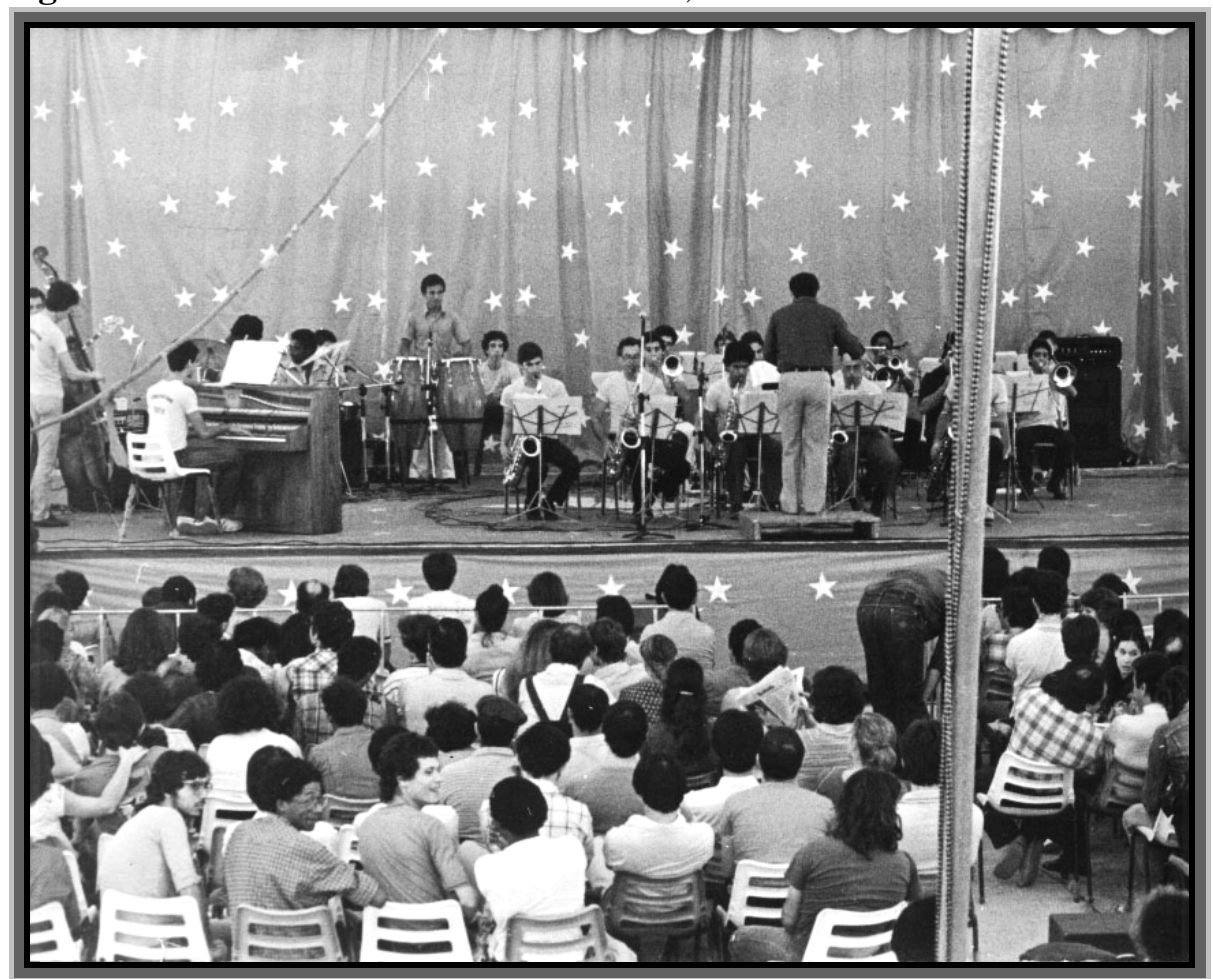

Fonte: Acervo do CDMCC

Figura 43 - Campeonato de Bandas, 1978. Diretor do CDMCC de Tatuí, José Coelho de Almeida, primeiro à direita.

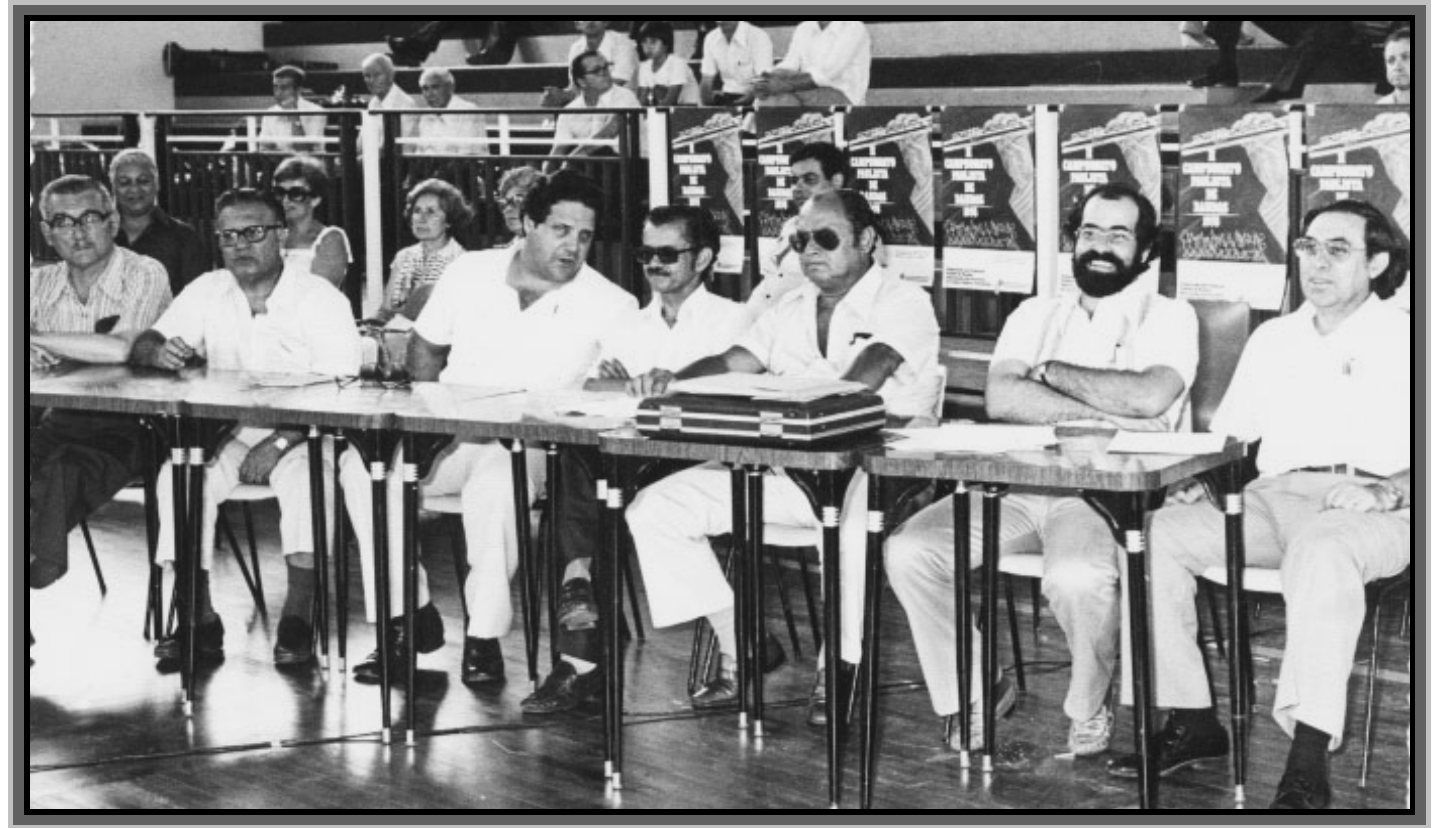

Fonte: Acervo do CDMCC 
Figura 44 - II Encontro Paulista de Bandas, CDMCC de Tatuí, 1979.

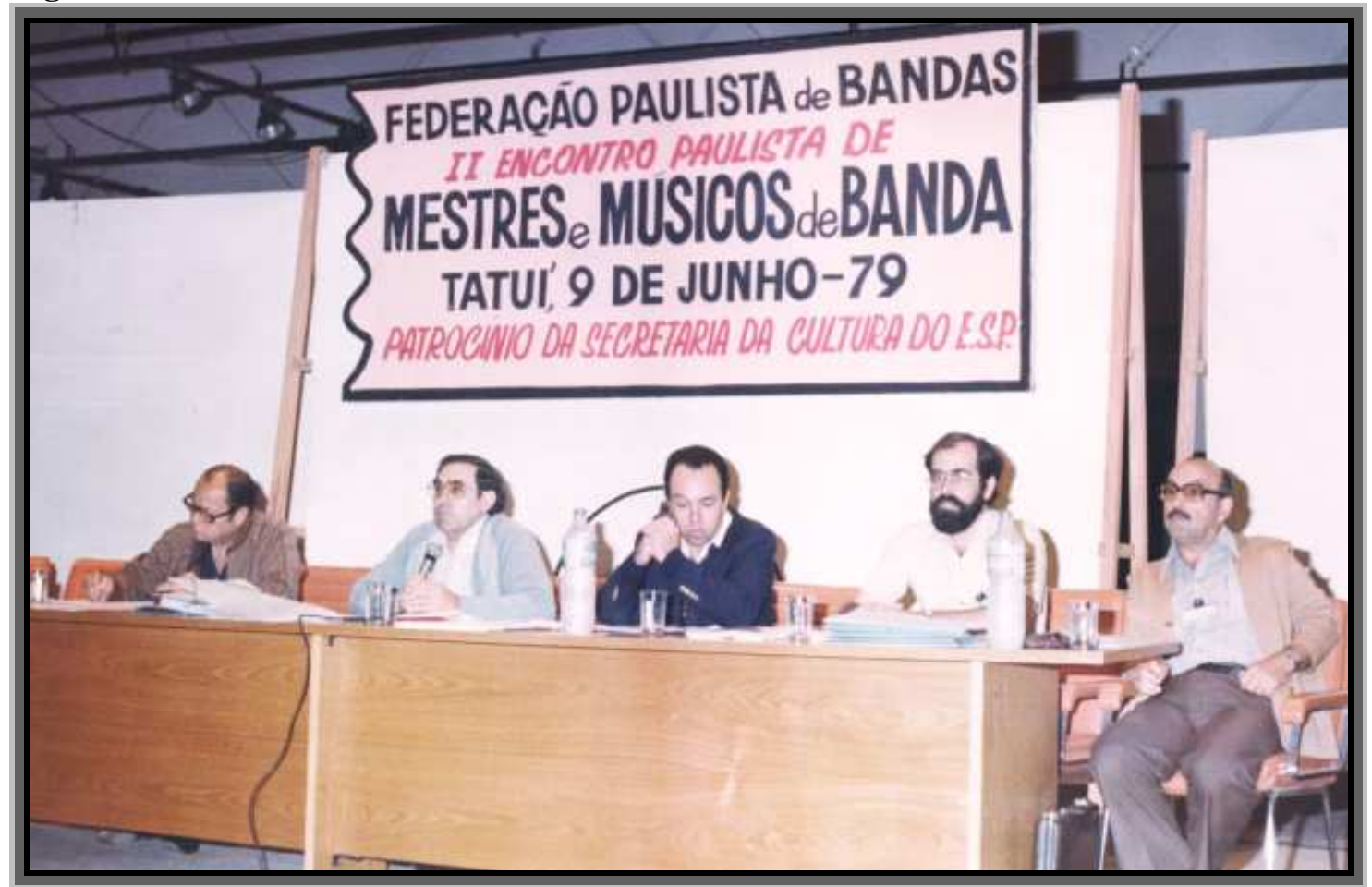

Fonte: Acervo do CDMCC.

Também nesse ano, entre concertos, recitais, retretas e outras audições o conservatório realizou cerca de 150 apresentações públicas em Tatuí, e em outras cidades do Estado e do País.

O Jornal do Brasil da cidade do Rio de Janeiro declarou que “...o conservatório Dr. Carlos de Campos de Tatuí pretende realizar uma evolução profissional do músico brasileiro, o que serviria de exemplo para o restante do país.Para atingir seus objetivos, o conservatório conta ainda com a boa disposição das autoridades das principais cidades próxima a Tatuí (o que representa cerca de 600 mil habitantes) que vêem naquela casa uma excelente contribuição para o equilíbrio social de toda a população, criando possibilidades de um grande centro cultural através dos mais diversos setores, como artes plásticas, cinema e teatro."10

\footnotetext{
${ }^{10}$ Artigo reproduzido na íntegra, cedido pelo CDMCC-o artigo consta apenas como recorte, sem referencias a data.
} 
Figura 45 - Apresentação da Banda Sinfônica sob a regência do Diretor José de Almeida Coelho na Praça da Concha Acústica em Tatuí.

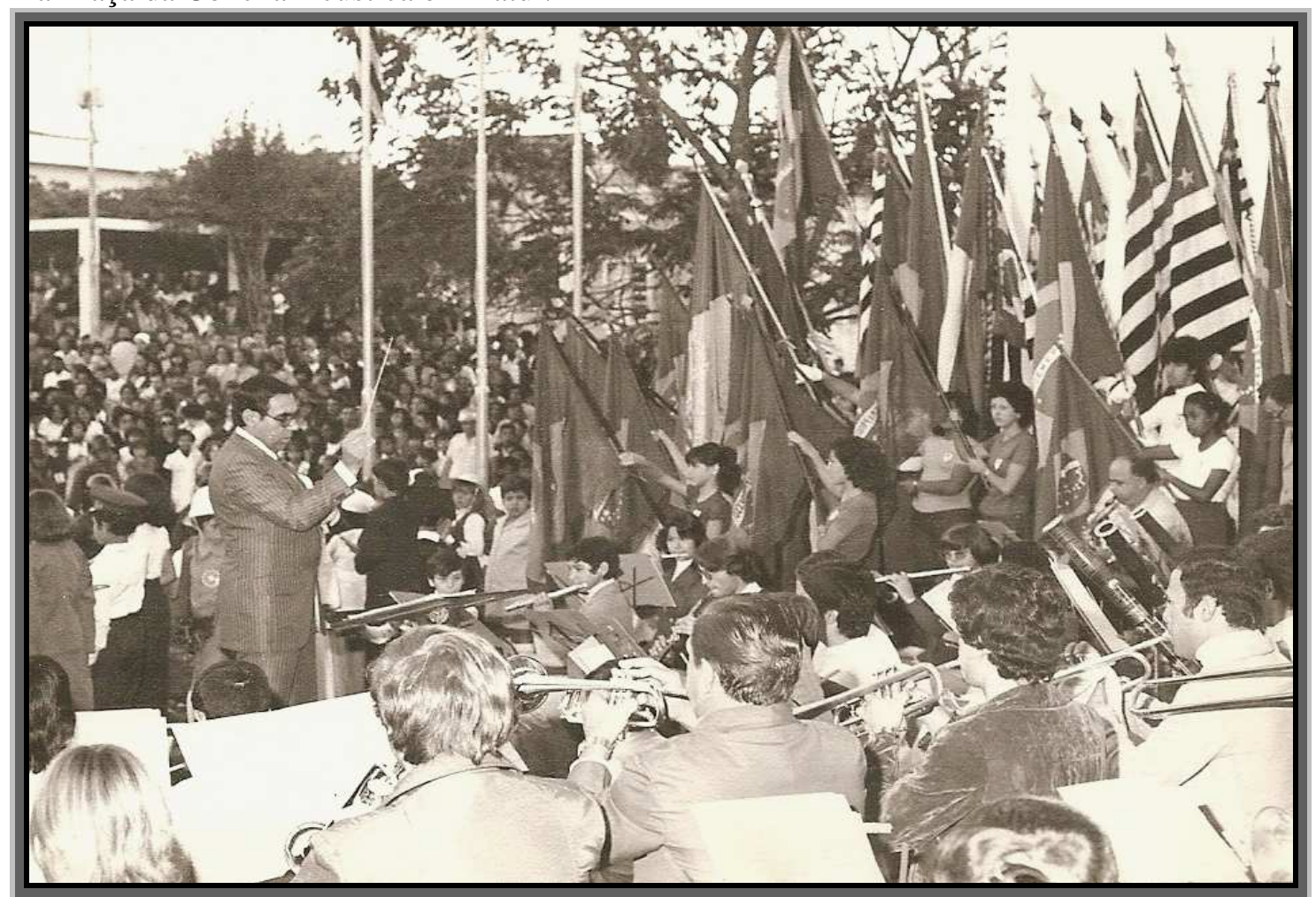

Fonte: Acervo do CDMCC

Figura 46 - Grande público presente no referido concerto.

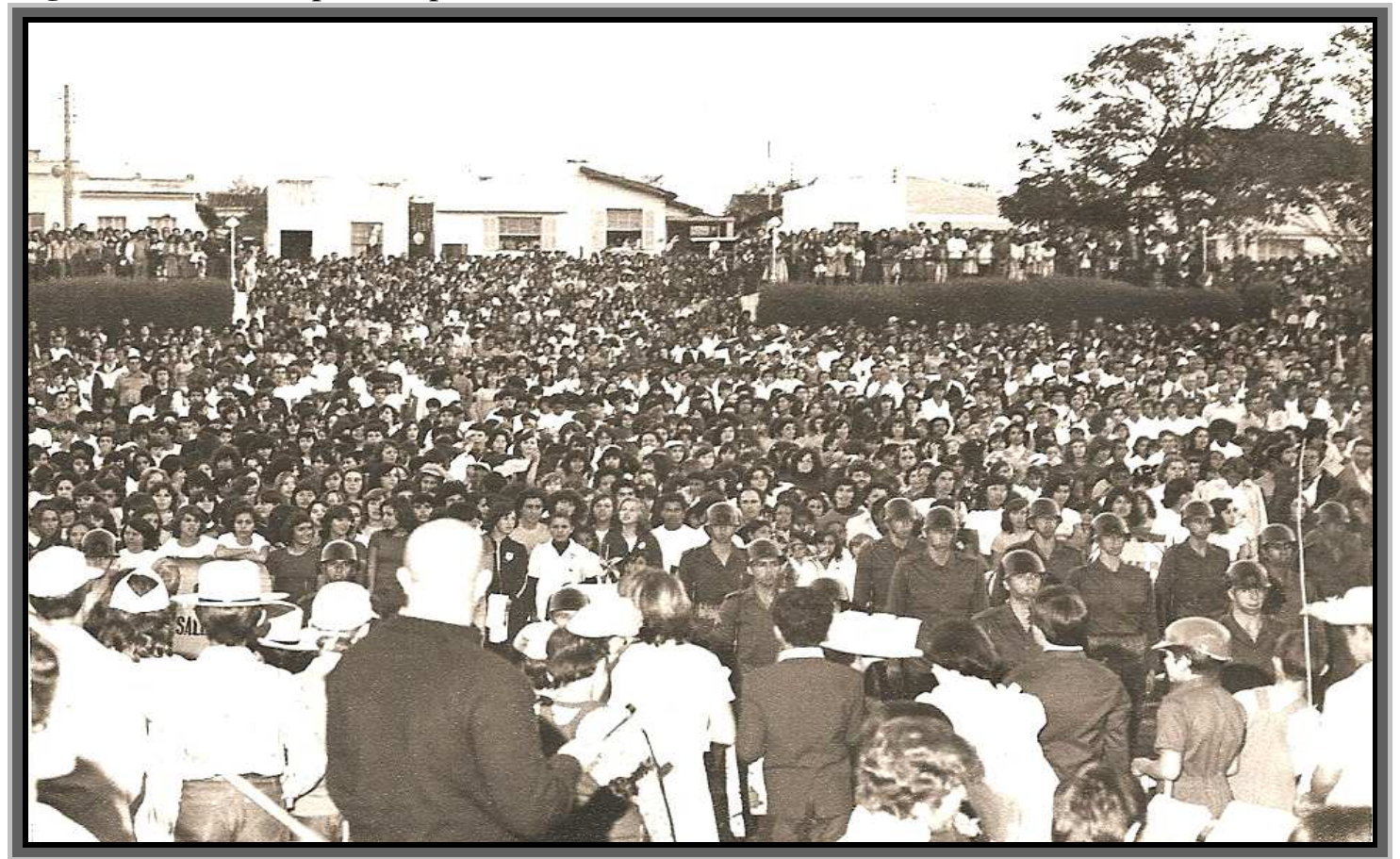

Fonte: Acervo do CDMCC 
Para difusão musical o conservatório dispunha de doze grupos formados por professores e alunos assim divididos: orquestra sinfônica, orquestra de câmara, coral, banda sinfônica, quarteto Villa-Lobos de violões, Grupo Bach de violões, Conjunto de metais, grupo de jazz, fanfarras, orfeão infantil, quinteto de sopros infantil, orquestra infantil.

Figura 47 - Orquestra infantil 1975. O garoto que ocupa a vaga de concertino com olhar atento ao maestro, chama-se José Roque Cortez, atualmente atua como professor e músico da escola.

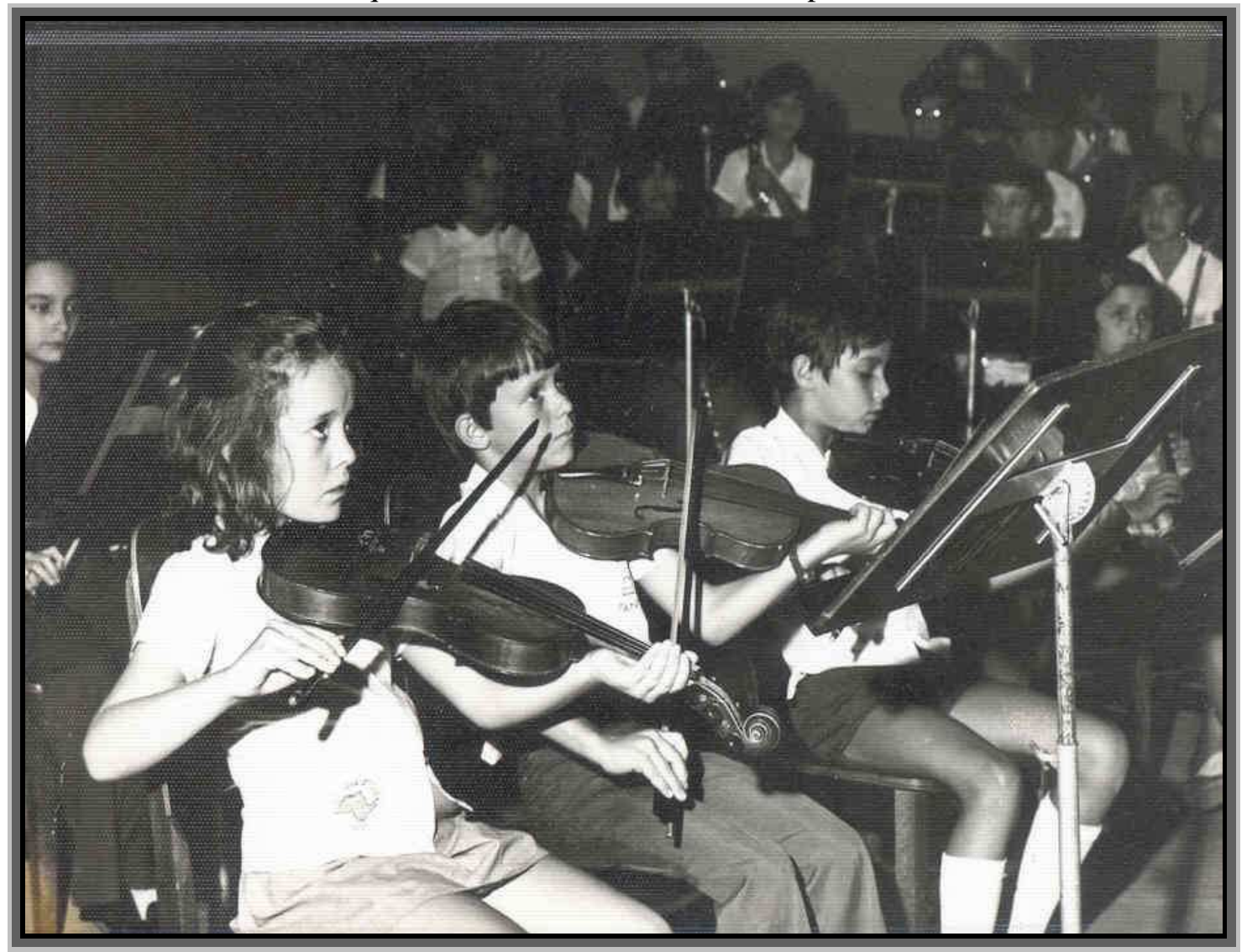

Fonte: Acervo do CDMCC. 
Figura 48 - Grupo Bach de violões.

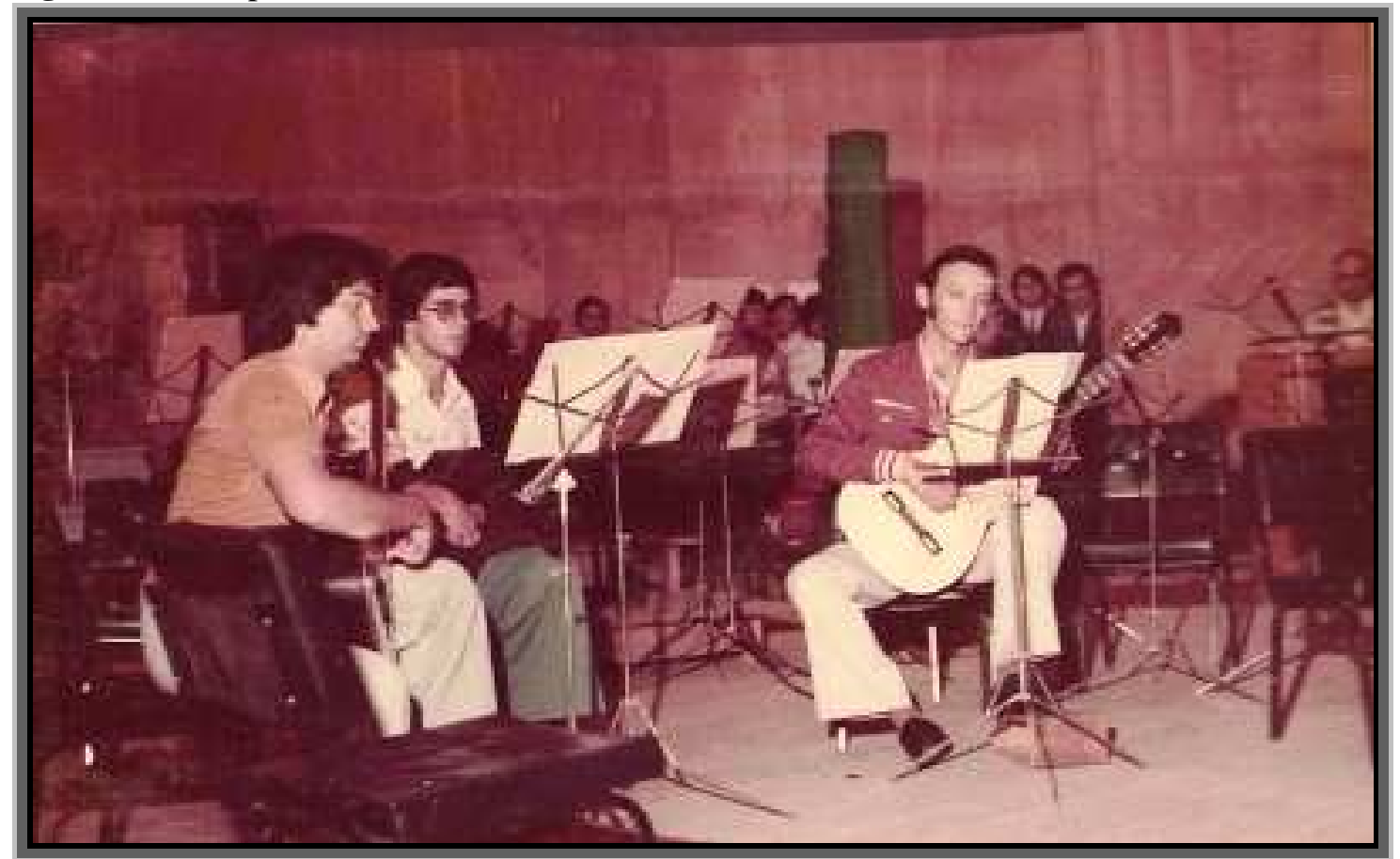

Fonte: Acervo do CDMCC

Figura 49 - Banda. José Coelho de Almeida na extrema esquerda, ao seu lado e acima o ex-aluno e atual professor de saxofone da escola, Luiz Carlos Rodrigues.

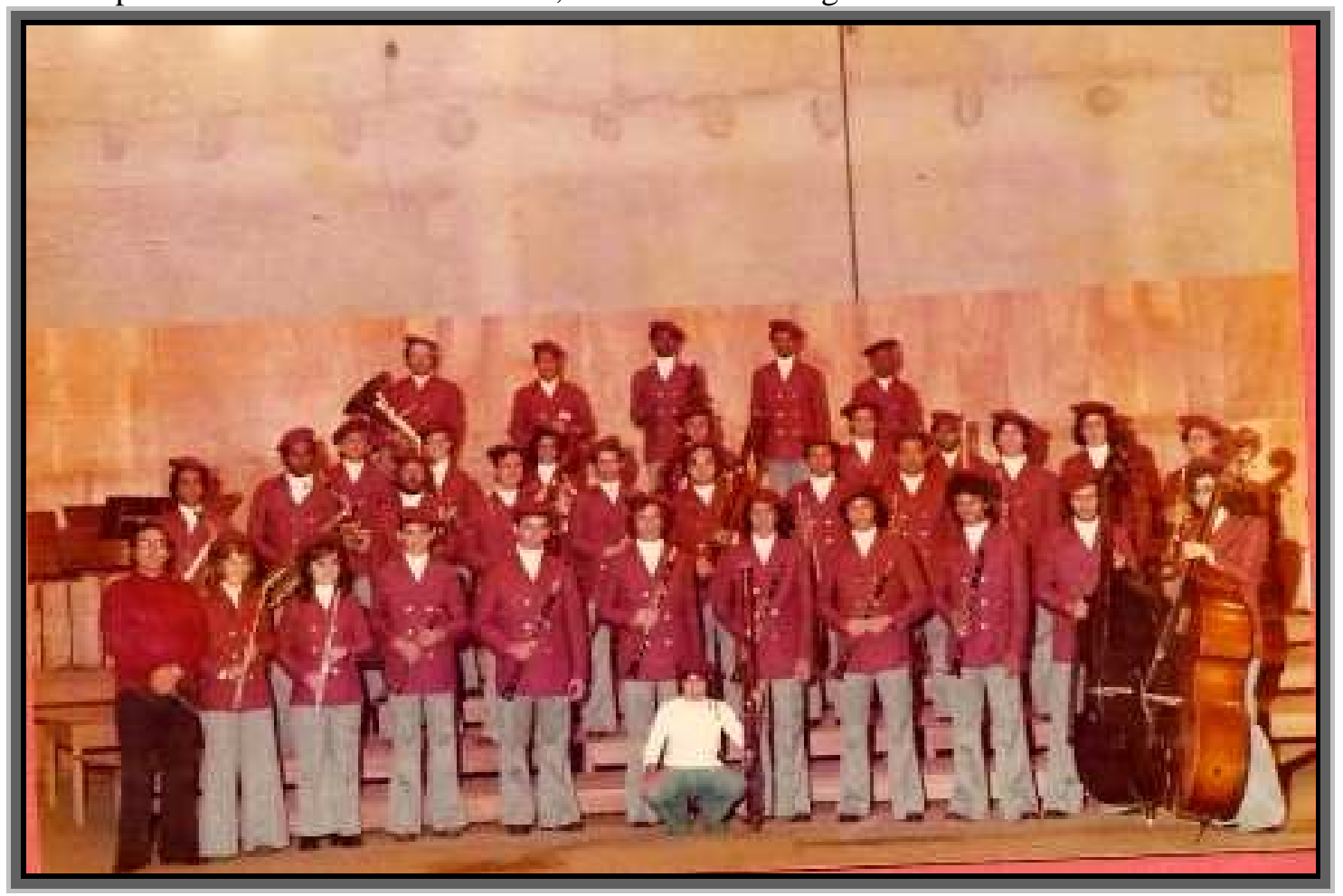

Fonte: Acervo do CDMCC. 
Figura 50 - Coral. Ao centro em destaque, professora Regina Orsi, ex-coordenadora da área de música de câmara, atual professora correpetidora.

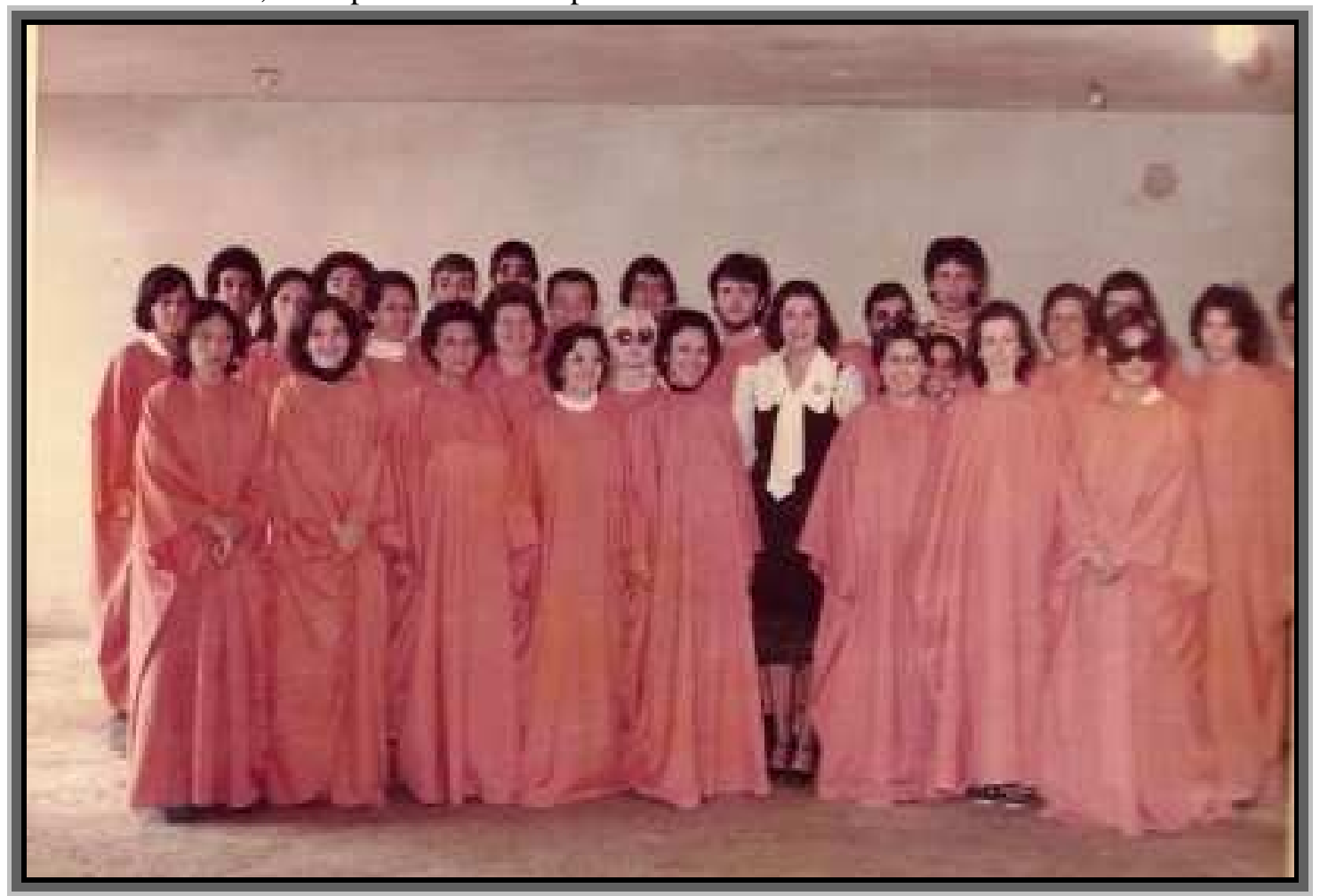

Fonte: Acervo do CDMCC.

Figura 51: Coral juvenil, com acompanhamento de violão ao fundo.

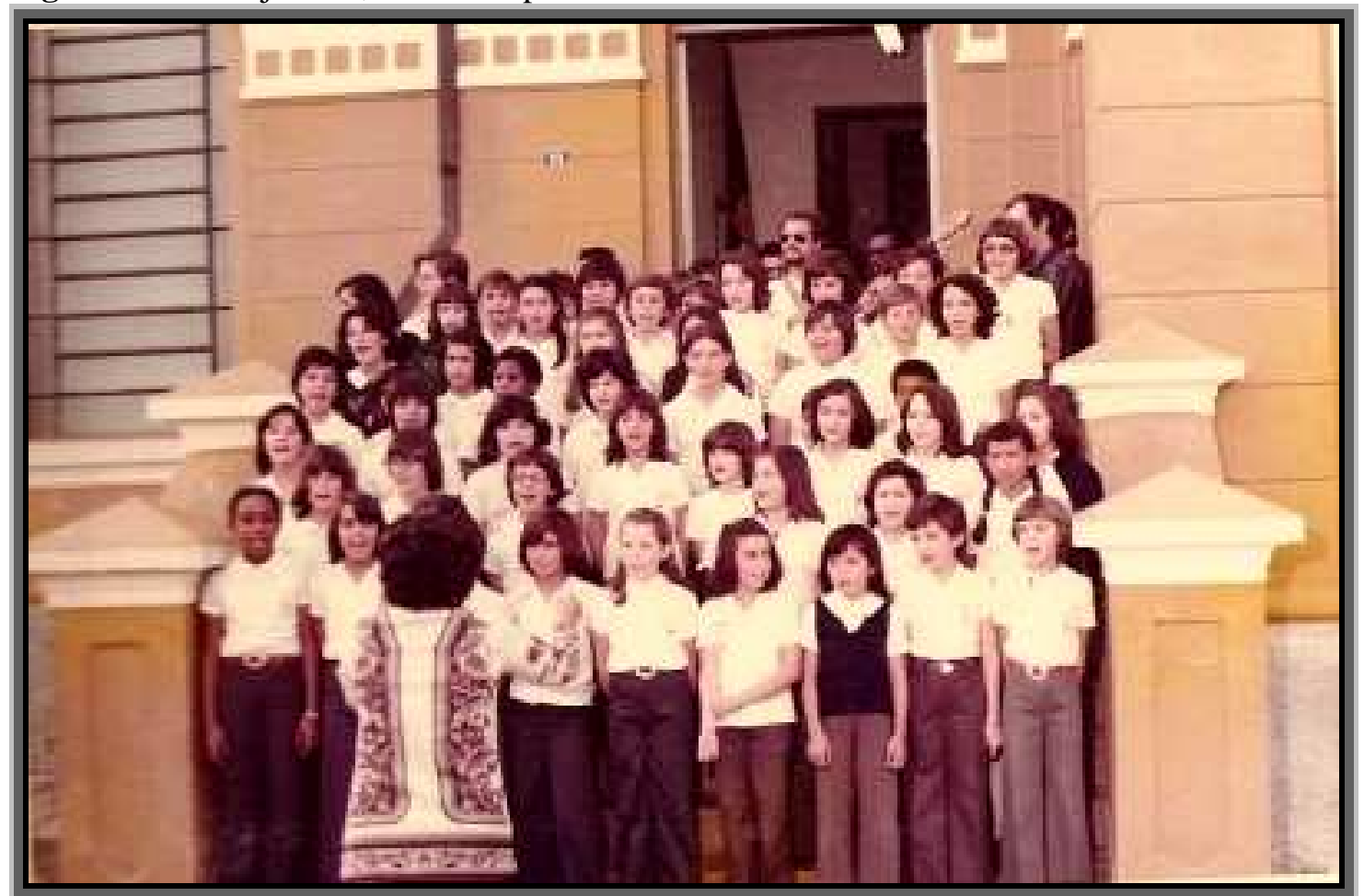

Fonte: Acervo do CDMCC. 
Figura 52 - Grupo Lírico.Ao centro da foto ex-integrante do grupo e atual professora da escola professora Angelina Colombo Ragazzi.

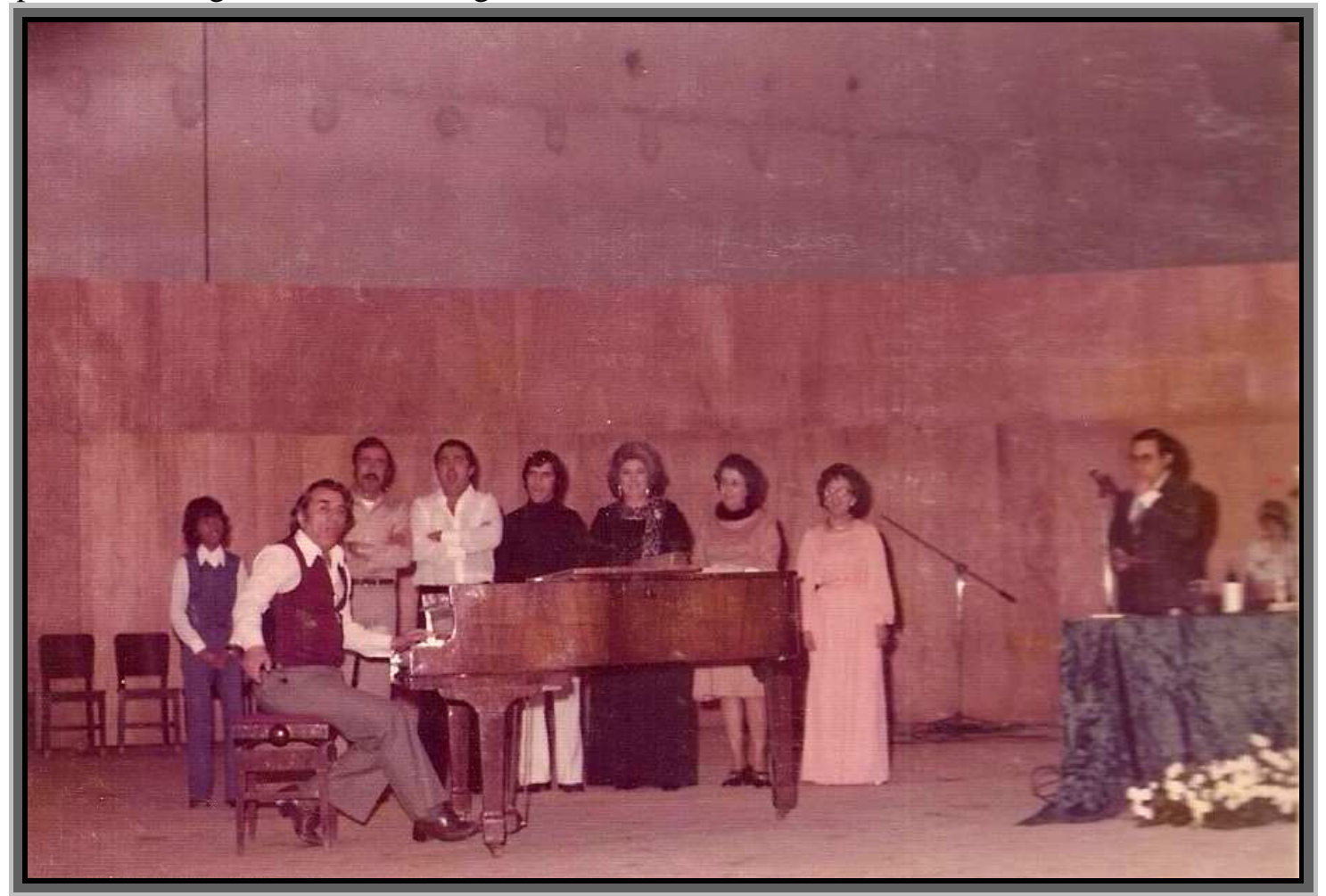

Fonte: Acervo do CDMCC.

Figura 53 - Música de Câmara. Ao lado direito, Maestro Eleazar de Carvalho em sua primeira visita ao conservatório.

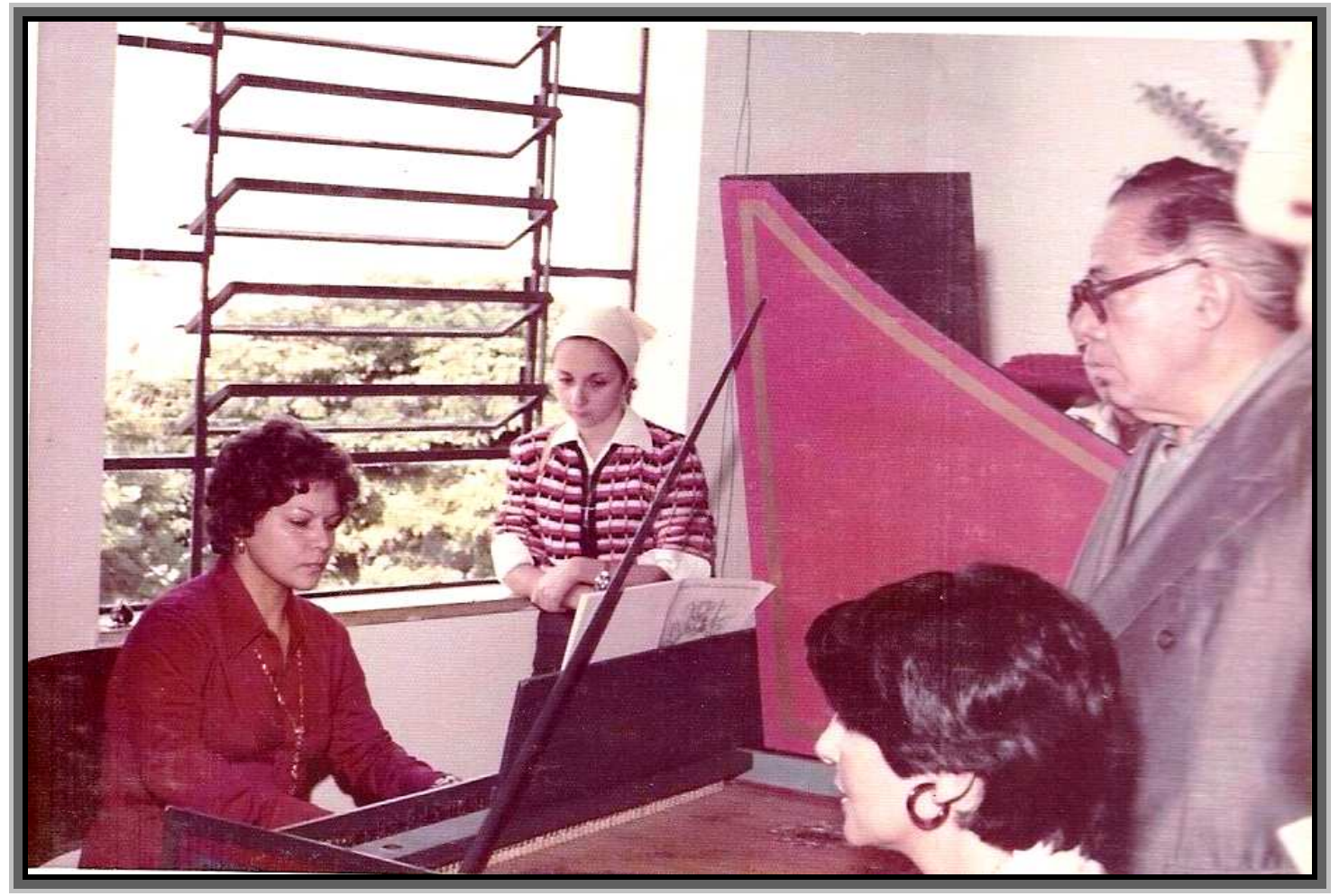

Fonte: Acervo do CDMCC. 
Figura 54 - Orquestra de cordas.

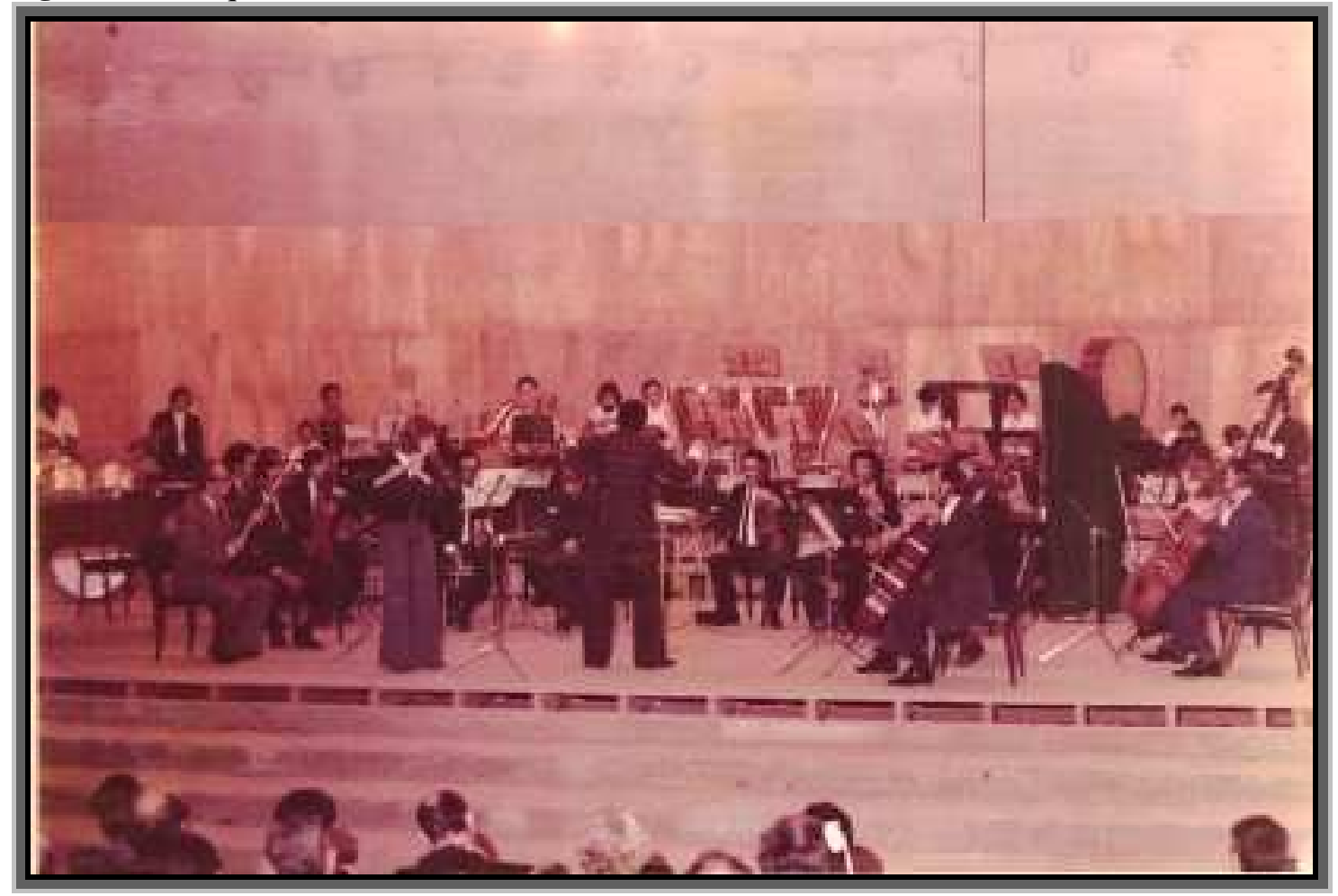

Fonte: Acervo do CDMCC.

Figura 55 - Sam Jazz. Ao piano o ex- professor e ex -Diretor do CDMCC Antonio Carlos Neves Campos.

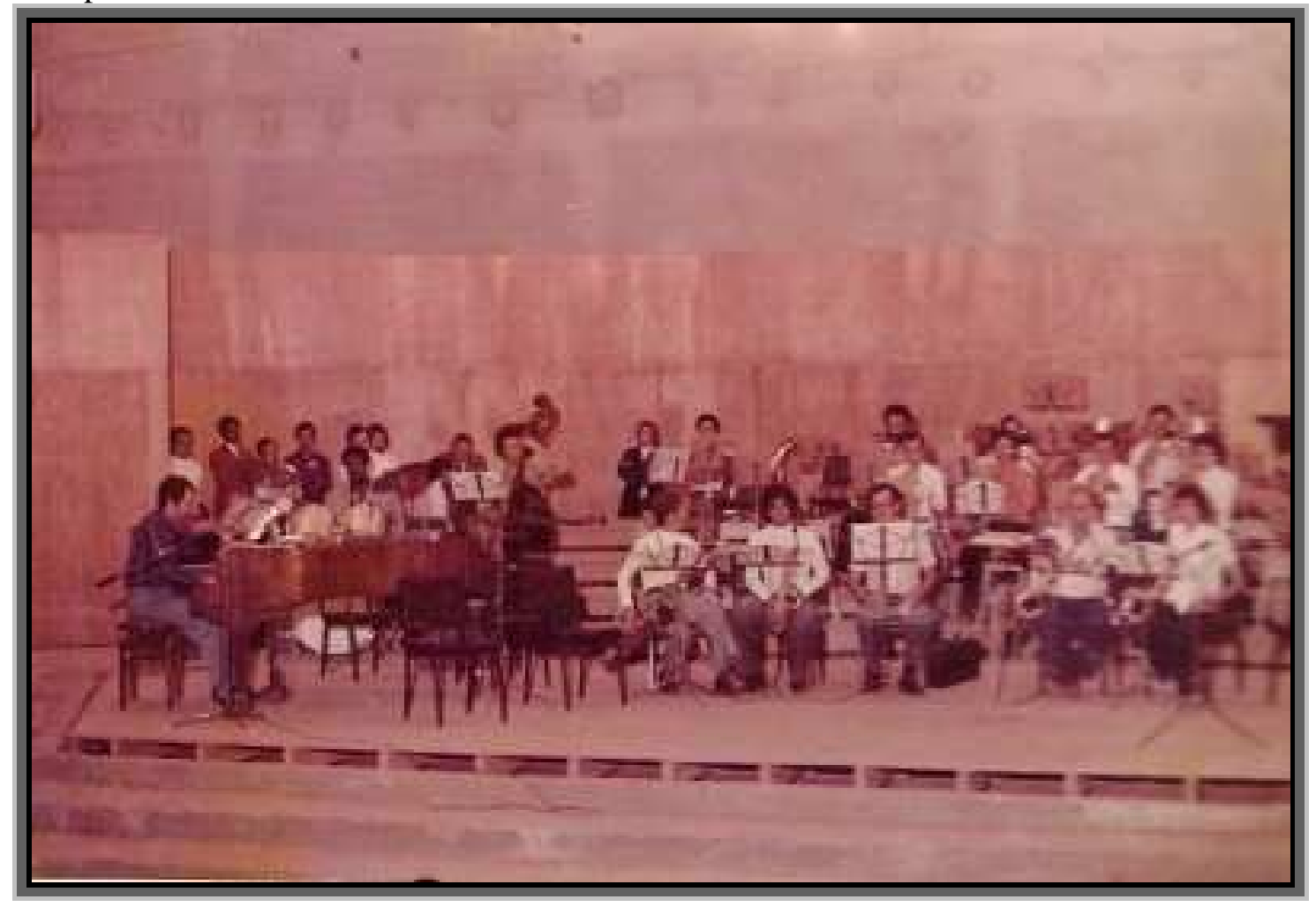

Fonte: Acervo do CDMCC. 
Figura 56 - Apresentação de uma classe de educação musical. Da esquerda para a direita: Maestro Eleazar de Carvalho, Sr. Effer e prof. José Coelho de Almeida.

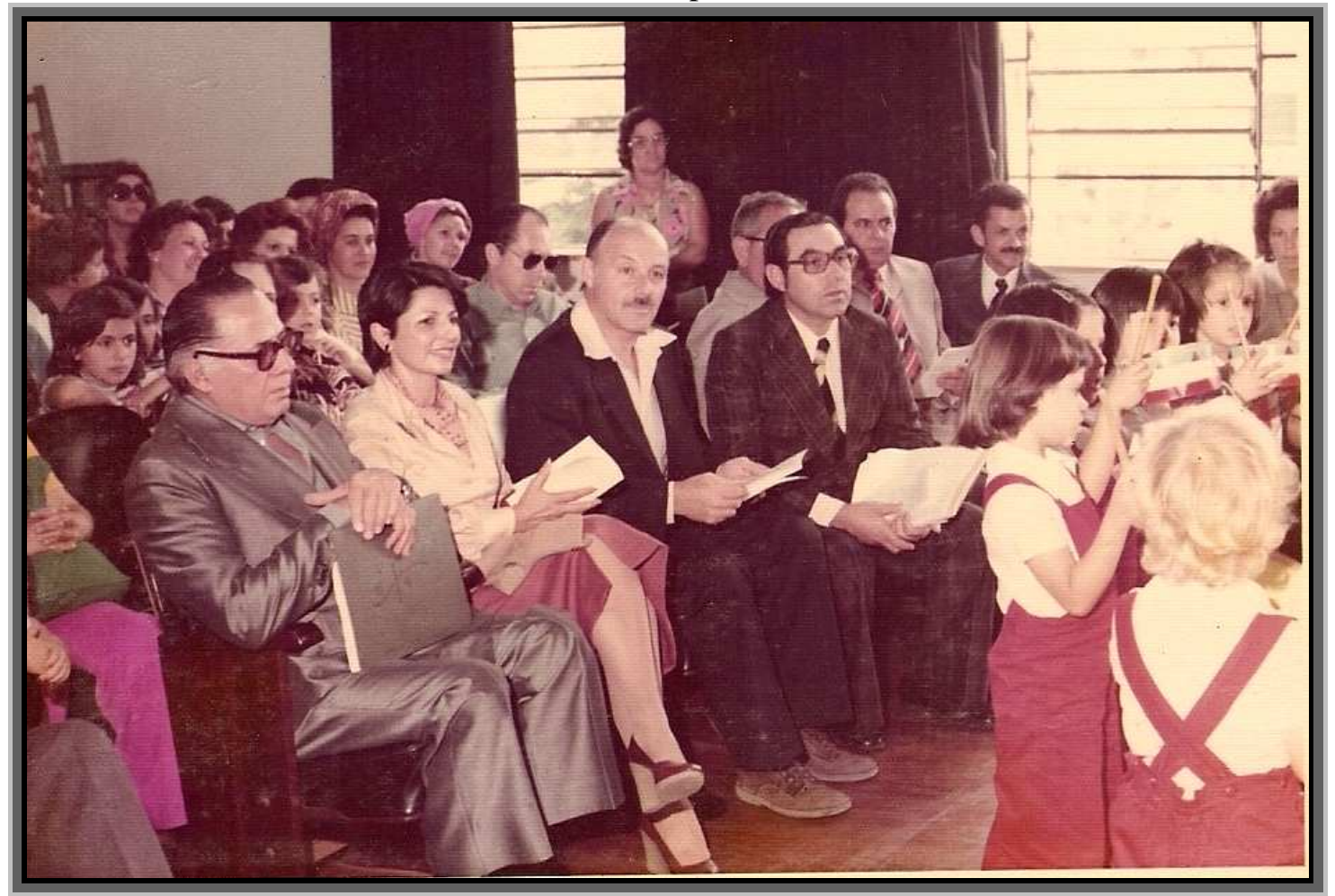

Fonte: Acervo do CDMCC.

Figura 57-Trio de Cordas. Ao violoncelo um dos idealizadores dessa instituição, João Del Fiol.

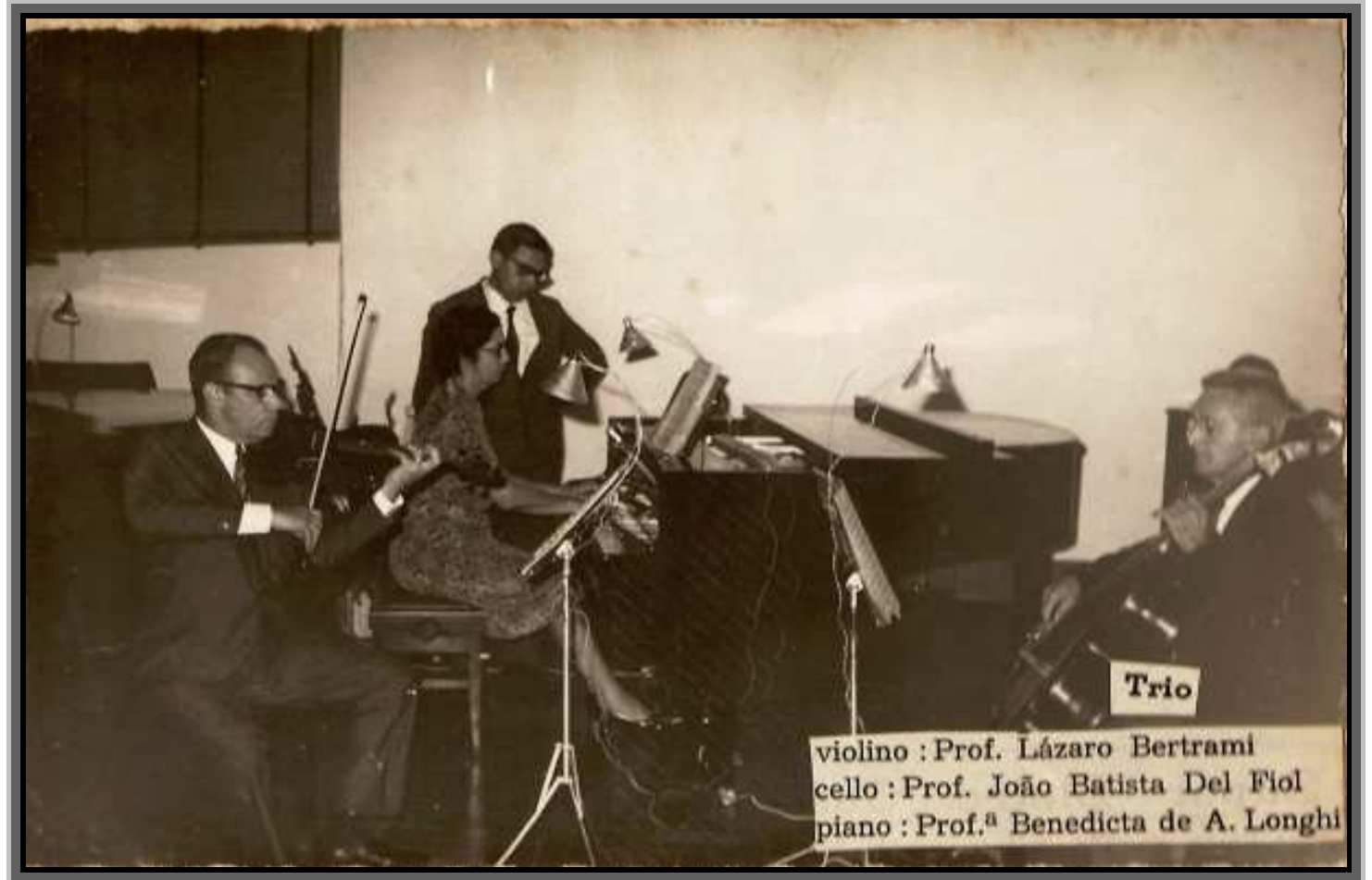

Fonte: Acervo do CDMCC. 
Figura 58 - Apresentação da orquestra sinfônica sob a regência do maestro Jamil Maluf, em 1980.

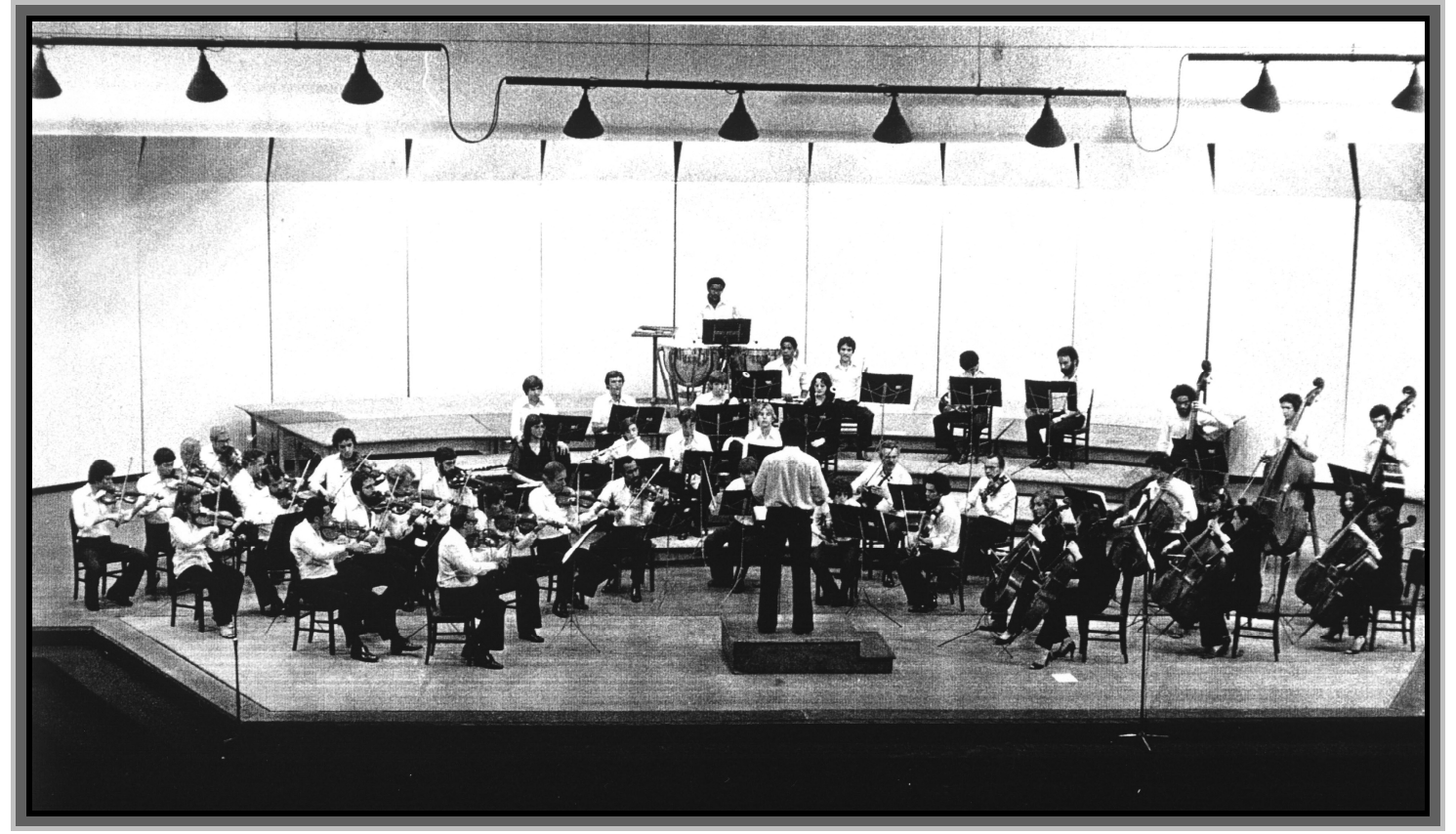

Fonte: Acervo do CDMCC.

Figura 59 - Apresentação do CDMCC de Tatuí em São Paulo em 1980, tendo como solista exaluno e atual professor o flautista Édson Beltrami, sob a direção do Diretor José Coelho de Almeida.

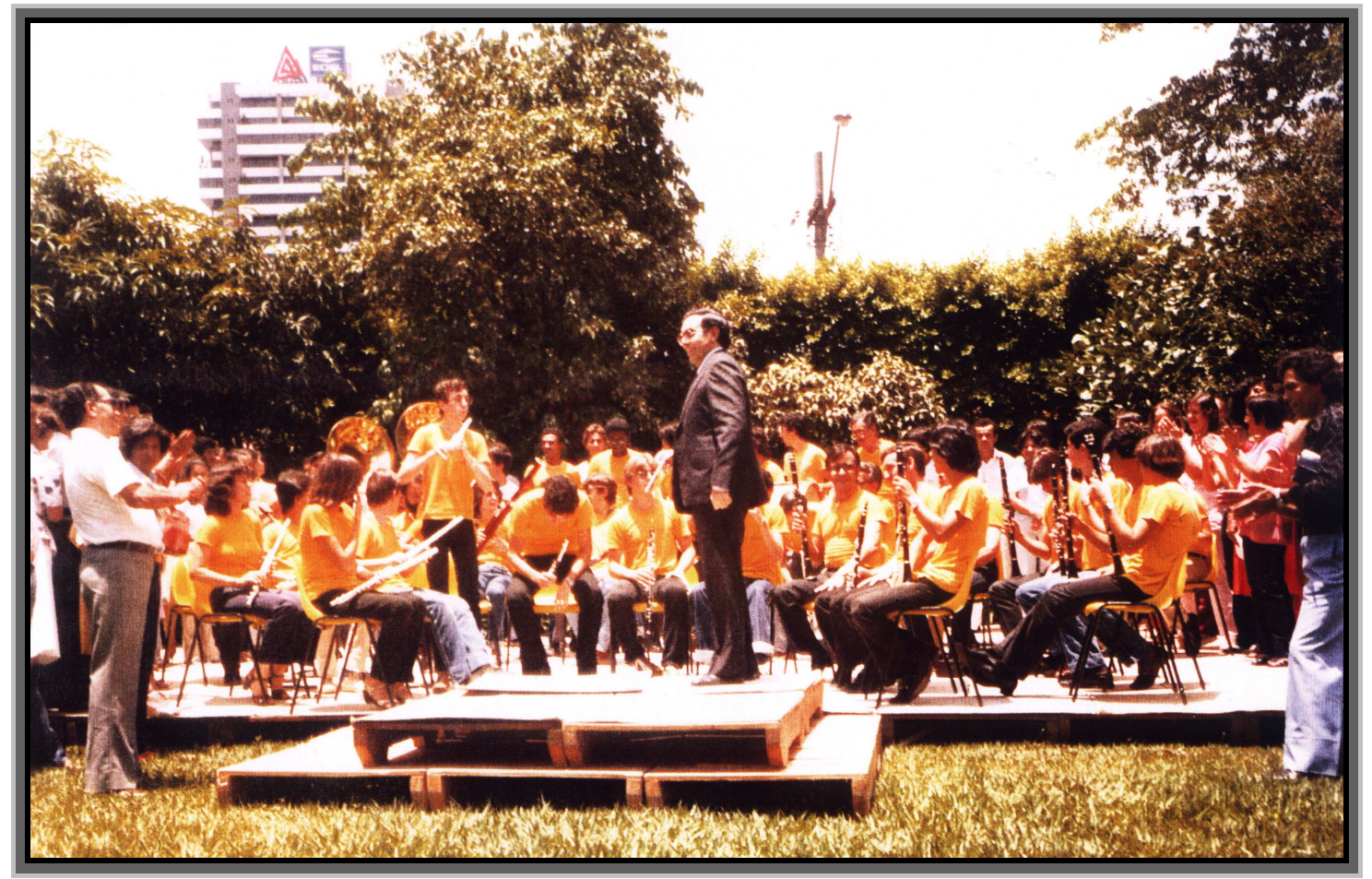

Fonte: Acervo do CDMCC. 
Figura 60 - Jubileu de Prata do CDMCC, 1979.

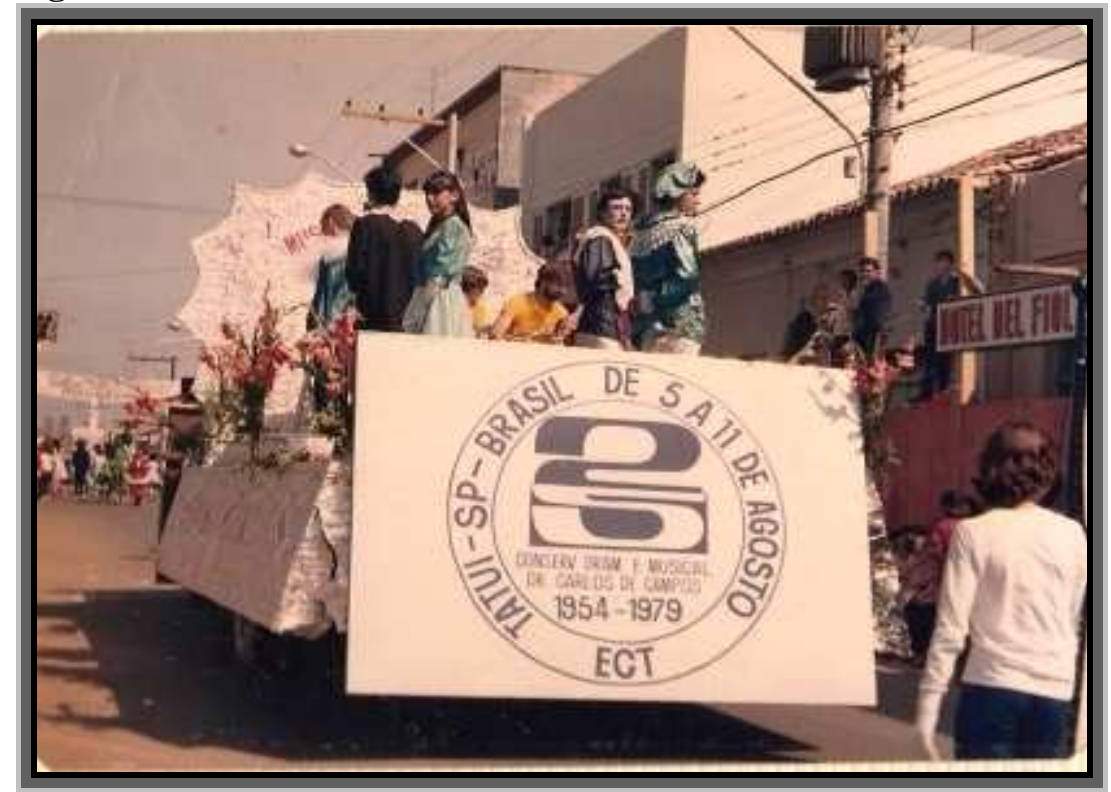

Fonte: Acervo do CDMCC.

Para desenvolver suas atividades, o conservatório contava em seu acervo com 26 violinos, 06 violas, 04 violoncelos, 06 contrabaixos, 09 flautas, 02 flautins, 02 oboés, 09 clarinetas, 01 clarineta baixo, 02 saxofones alto, 02 saxofones tenor, 03 fagotes, 05 tropas, 06 trompetes, 01 tuba, 03 pianos $1 / 4$ de cauda, 12 pianos de armários, 08 violões, 01 harpa, 04 tímpanos, 02 petit-bugles, 01 requinta, 01 corno inglês, 01 piano elétrico. Grande parte do instrumental adquirido na gestão Coelho, permanece utilizada até os dias atuais.

Figura 61 - Semana da Pátria-Exposição dos instrumentos.

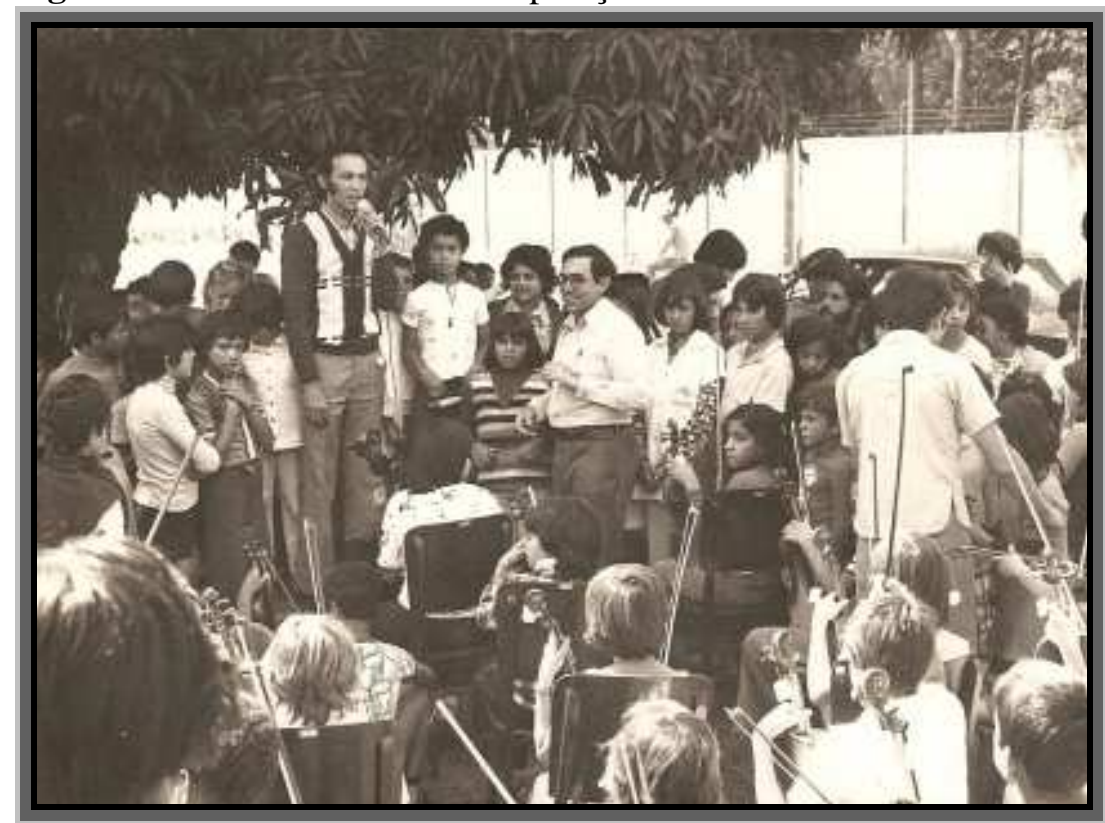

Fonte: Acervo do CDMCC. 
Figura 62 - Semana da Pátria-Exposição dos instrumentos.

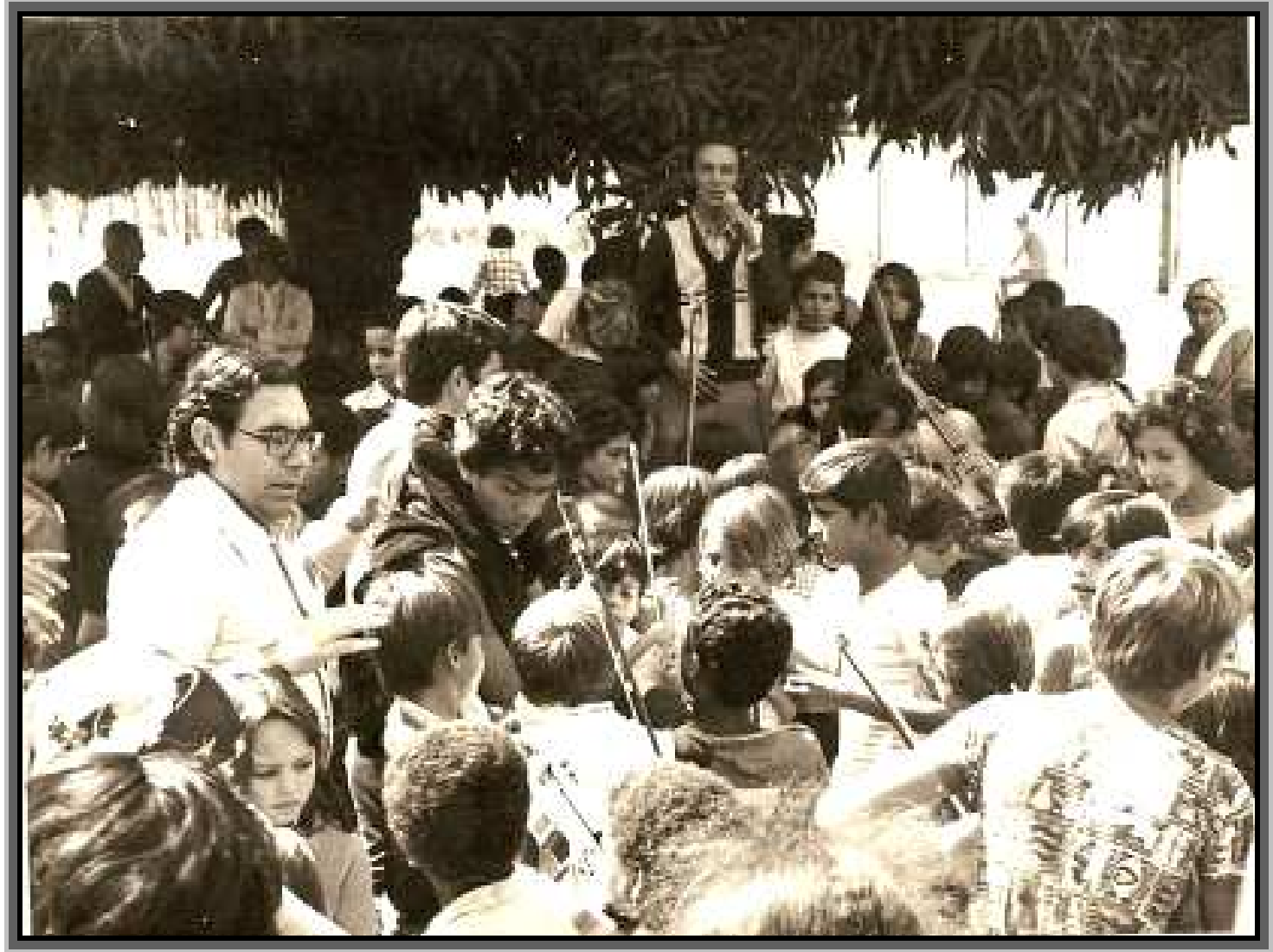

Fonte: Acervo do CDMCC.

Figura 63 - Semana da Pátria-Exposição dos instrumentos.

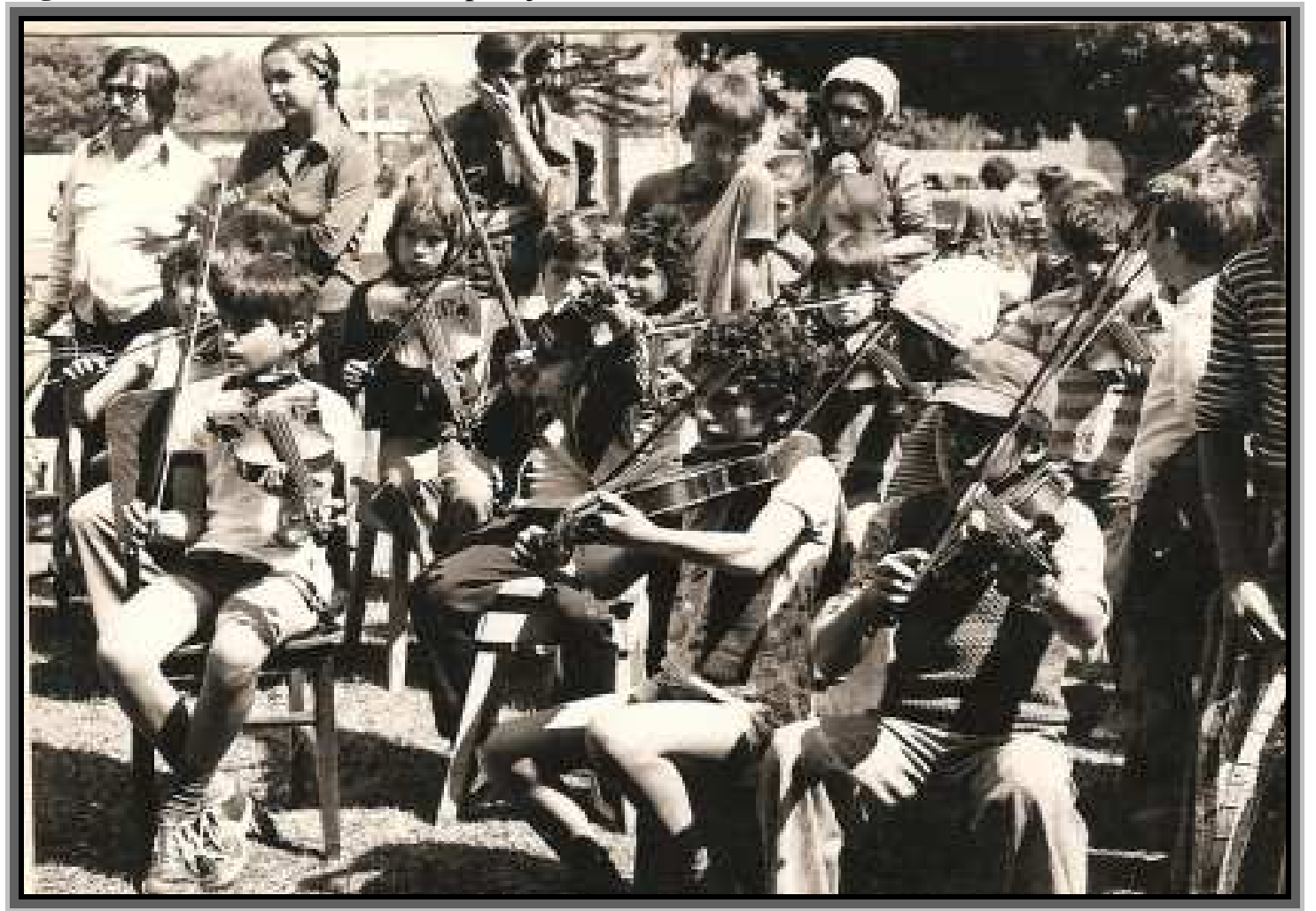

Fonte: Acervo do CDMCC. 
Figura 64 - Semana da Pátria-Exposição dos instrumentos.

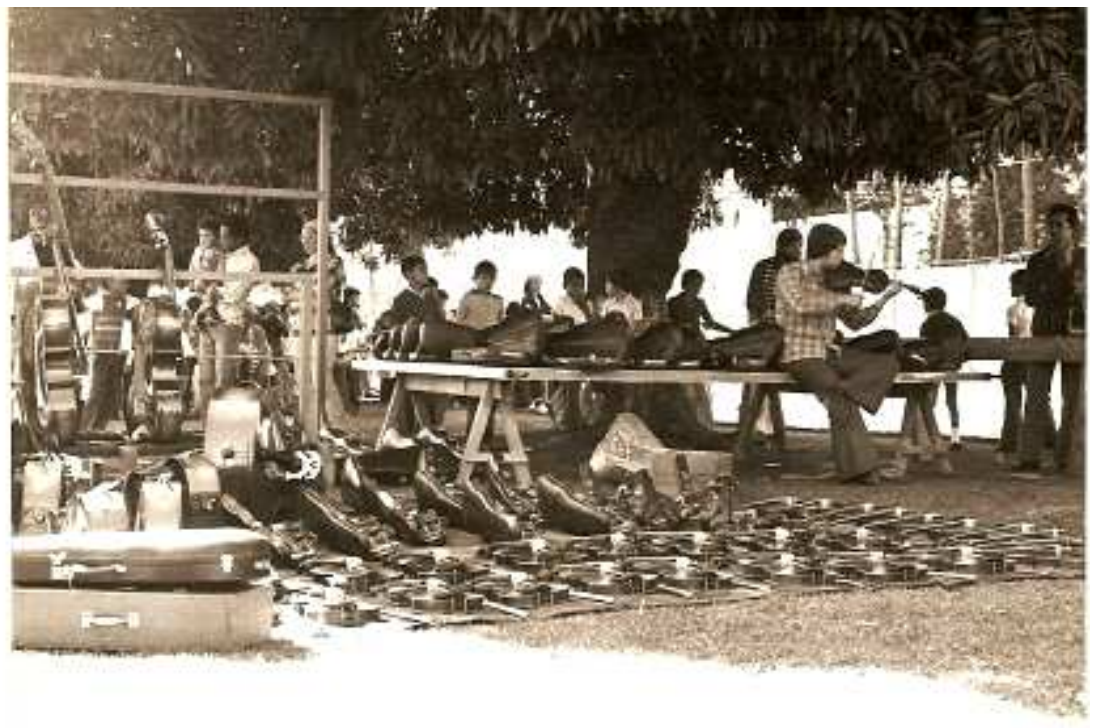

Exposiçâo de instrumentos de corda que estarão à disposição das crianças: 30 violinos, 12 violas, 6 violoncelos e 2 contrabaixos.

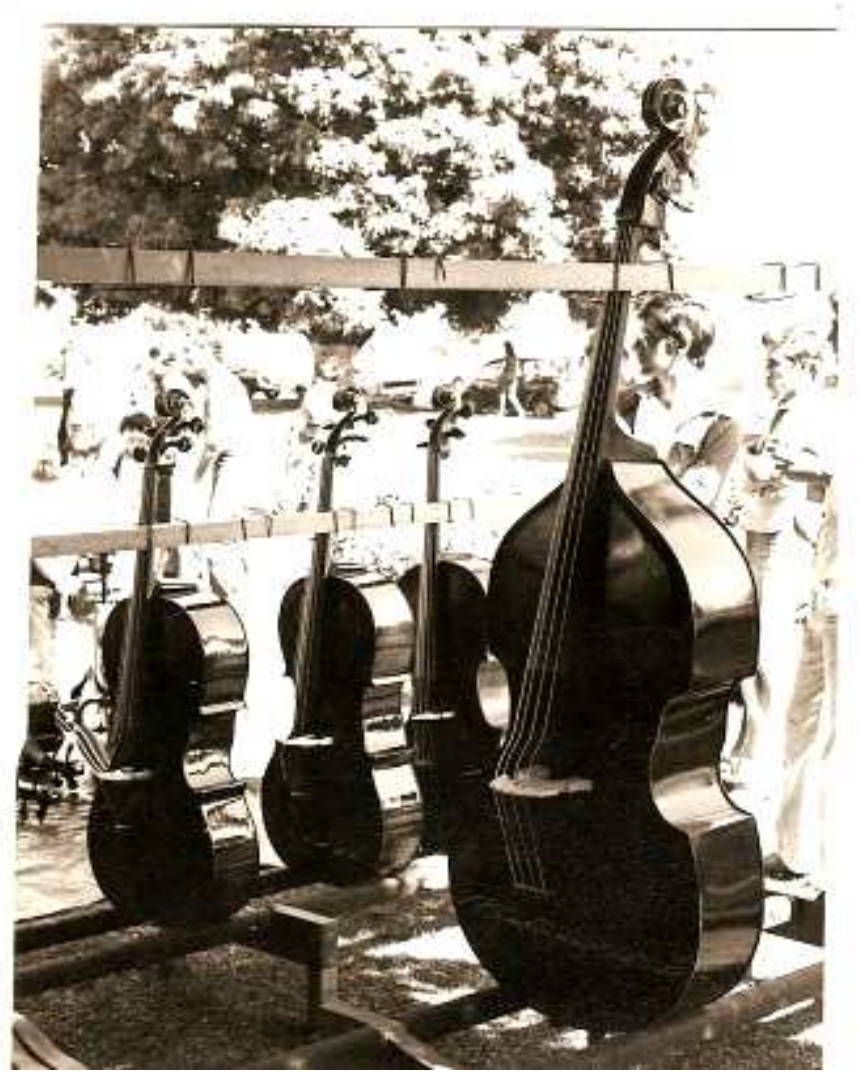

Fonte: Acervo do CDMCC. 
"Tudo o que choca, conscientiza." (Koellreutter) 


\section{CAPÍTULO V}

\section{AS MUDANÇAS NA POLÍTICA CULTURAL BRASILEIRA}

\section{A gestão Hans Joaquim Koellreutter (1983-1984)}

Figura 65 - H. J. Koellreutter.

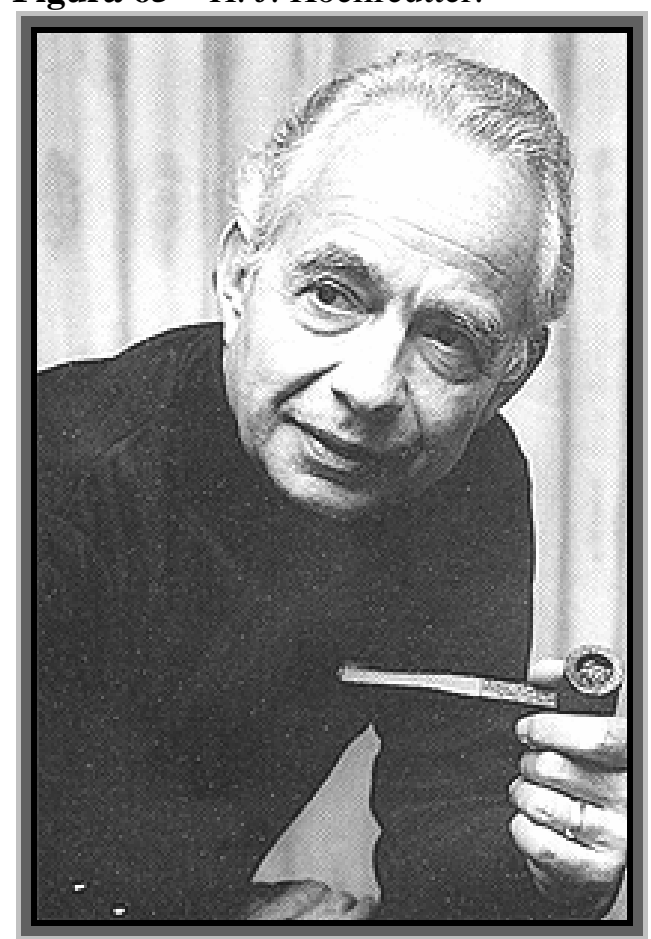

Fonte: Acervo INTERNET.

Em meados da década de 1980, a democratização do país mudaria o panorama cultural brasileiro contemporâneo. Greves, concentrações e protestos demonstraram o crescimento da organização de diversos setores da sociedade e tiveram papel importante no processo de abertura política do país.

Em 1983 é eleito para Governador do Estado de São Paulo o Sr. André Franco Montoro, houve a troca de todos os secretários e também do diretor do CDMCC de Tatuí. O músico alemão naturalizado brasileiro Hans-Joachim Koellreutter, iniciou sua gestão no CDMCC de Tatuí no primeiro semestre de 1983.

Nascido em Freiburg na Alemanha em 1915, flautista, regente e compositor, Koellreutter chegou ao Brasil em 1937 fugindo do nazismo, no Brasil, desenvolveu os mais diversos trabalhos musicais, professor, compositor, ensaísta e esteta, foi um dos primeiros a 
introduzir as inovações sonoras da Europa no Brasil. Em 11 de junho de 1937, marca o inicio do movimento Música Viva. Naturalizou-se brasileiro no final dos anos 50. Dirigiu diversos cursos e fundou escolas em São Paulo e Salvador, ensinou e compôs no Rio de Janeiro, no Conservatório Brasileiro de Música, e posteriormente, onde pôde executar com maior liberdade suas idéias, na Escola Livre de Música da Bahia, que ajudou a fundar.

Koellreutter tinha uma visão pedagógica que se afirmava na busca de identidade de cada aluno, incentivando-os pela procura de um caminho próprio e por uma liberdade de pensamento, algo bastante audacioso para o momento, sacudindo normas caducas e conservadoras da época.

Esse Diretor promoveu no CDMCC ensaios de música eletrônica, música atonal e serial, pois para ele “... a música agora não é só para sentir, mas também para compreender! ${ }^{11}$ ", ocasionando grande impacto nessa cidade do interior, muito mais preparada a ouvir musica que toca ao coração, ou que emociona; ponto de vista também discutido pelo compositor Camargo Guarnieri, em carta aberta escrita em 28 de Agosto de 1941:

“... nunca pude, ainda, apesar da minha franca simpatia pelo atonalismo, sem, entretanto, praticá-lo sistematicamente, encontrar beleza nas obras escritas atonalmente.Tenho a sensação que essas obras não chegam a ser belas, acho as profundamente intelectuais ${ }^{12}$..."

Conforme entrevista do Sr. João Eurico de Melo Toledo, secretário aposentado do CDMCC de Tatuí, Koellreutter, músico extremamente conceituado e com diversos interesses em São Paulo, ao que parece, não estava interessado em ser diretor do CDMCC de Tatuí, veio somente atendendo ao pedido de políticos.

"Como já havia acontecido tantas vezes, antes as concepções de música e cultura, as posições filosóficas, estéticas e ideológicas assumidas por koellreutter não meramente causaram estranheza, mas estimularam vivamente a reflexão e o debate, o confronto de idéias e posicionamento, que, em princípio, leva, à conscientização de si e da realidade sociocultural ${ }^{13}$."

Sua gestão foi a mais breve que houve no CDMCC de Tatuí e foi marcada por apelos de políticos locais de que o Conservatório deveria ser dirigido por uma pessoa que residisse na cidade e que estivesse comprometida com a administração do CDMCC de Tatuí.

\footnotetext{
${ }^{11}$ KATER Carlos, Música Viva e J.H.Koellreutter, movimentos em direção à modernidade, p. 90.

${ }^{12}$ Ibid., p. 282.

${ }^{13}$ Ibid., p. 203.
} 


\section{A gestão Antônio Carlos Neves Campos (1984 - 2007)}

Figura 66 - A. C. Neves de Campos.

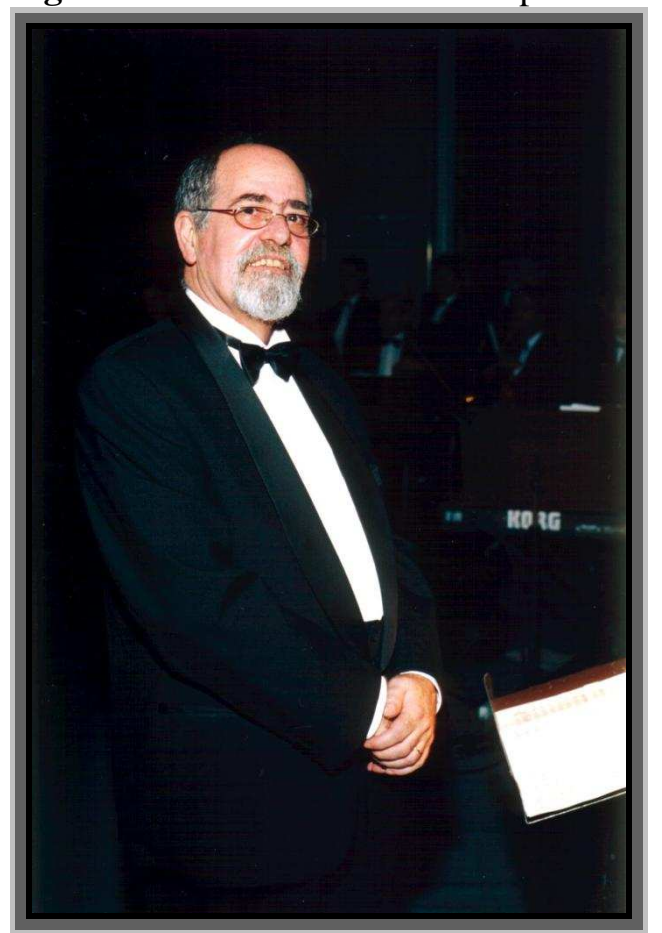

Fonte: Acervo do CDMCC.

É pertinente uma reflexão sobre o processo histórico do desenvolvimento musical de Tatuí, num primeiro momento aparecem as organizações locais ligadas à cultura com apoio da comunidade, posteriormente exercido sob a forma de mecenato pelo governo.

O estudo musical, segmento cada vez mais integrado ao crescimento econômico, surpreende aqueles que consideram o estudo da música desnecessário, especialmente num país que encontra enormes problemas sociais. A questão do financiamento desse segmento tem acompanhado um dilema, as necessidades de custeio e fomento, exercido por pouquíssimos e consumido por poucos.

Antonio Carlos Neves é formado em odontologia, profissão que exerceu por 25 anos, formou-se pelo CDMCC no ano de 1973 sendo o segundo pianista homem a conquistar o diploma obtido preferencialmente por mulheres. Em 1974 bem antes de assumir a direção, Antonio Carlos Neves passa a integrar o corpo docente da escola e junto com outros professores e alunos formam a Big Band Sam Jazz, primeiro movimento de cunho popular instaurado na escola, ênfase que prevaleceria em sua gerência como Diretor. Antonio Carlos 
Neves chegou à direção através de indicação de políticos locais e de professores do CDMCC, gozando de grande apreço por parte da população local pelo forte apelo populista deste Diretor durante toda a sua gestão.

Antonio Carlos C. Neves literalmente abriu as portas desse conservatório, alcançando um recorde ao termino de sua direção chegando a ter mais de 3000 alunos matriculados. O CDMCC de Tatuí nesse período passou a aceitar inicialmente pessoas de faixa etária avançada, "fora" da proposta inicial que era de aceitar apenas crianças ou préadolescentes para o estudo dos instrumentos.

O Diretor Antonio Carlos C. Neves explica que:
"É necessário mostrar ao público que freqüenta as apresentações musicais no teatro Procópio Ferreira, que para se trabalhar em uma firma é dado uniforme, máquina e todos os mecanismos necessários para que a pessoa possa desenvolver suas funções, porém o músico não dispõe desses recursos. O músico tem que ter um bom instrumento e mantê-lo, comprar sua roupa para apresentações, então é uma profissão diferenciada, o músico nunca pode parar de estudar, é como o esporte, não pode parar de praticar, o músico, quando vive da música tem de estar permanentemente atualizado, seja em equipamento, em informações, em estudo para poder vencer os "desafios" que a música traz durante a profissão. Já o musico que não quer se profissionalizar não precisa de nada disso e faz musica da mesma maneira". ${ }^{14}$

Na visão desse Diretor a função da escola, além de formar, informar e educar é também de formação de público, como complemento a sua formação acadêmica, proporcionando que esses alunos mesmo que não venham a se profissionalizar possam ser bons ouvintes, formando um público diferenciado para a própria escola. Essa democratização do ensino musical no inicio foi interessante para a instituição, pois trouxe mais visibilidade, mais verba e projeção.

Devido ao grande numero de alunos matriculados o conservatório passou a ter grandes problemas com a falta de espaço físico para aulas e ensaios de grupos, gerando a necessidade de se alocar quatro prédios para comportar essa demanda. Esta visão pragmática gerou criticas entre os docentes mais preocupados com a qualidade do ensino oferecido pelo CDMCC do que com a quantidade de alunos.

Uma das grandes preocupações do corpo docente e discente era a falta de profissionais no conhecimento teórico, o qual ficou bastante negligenciado nesse período pela direção do CDMCC, pois dispunha apenas de quatro professores abrangendo as matérias de Teoria, Solfejo, Harmonia e Contraponto, Coral, Historia da Musica, Acústica e Folclore,

\footnotetext{
${ }^{14}$ Entrevista do ex-Diretor Antonio Carlos Neves Campos cedida em Julho/2007.
} 
sobrecarregando os profissionais e consequentemente o CDMCC passou a ter alunos com conhecimentos rudimentares nessas matérias.

Segundo Sonia Regina Albano de Lima ${ }^{15}$ esta é uma pratica bastante comum à maioria dos educadores musicais em não valorizar a parte teórica e sim priorizar a pratica musical.

Figura 67 - Anexo 3.

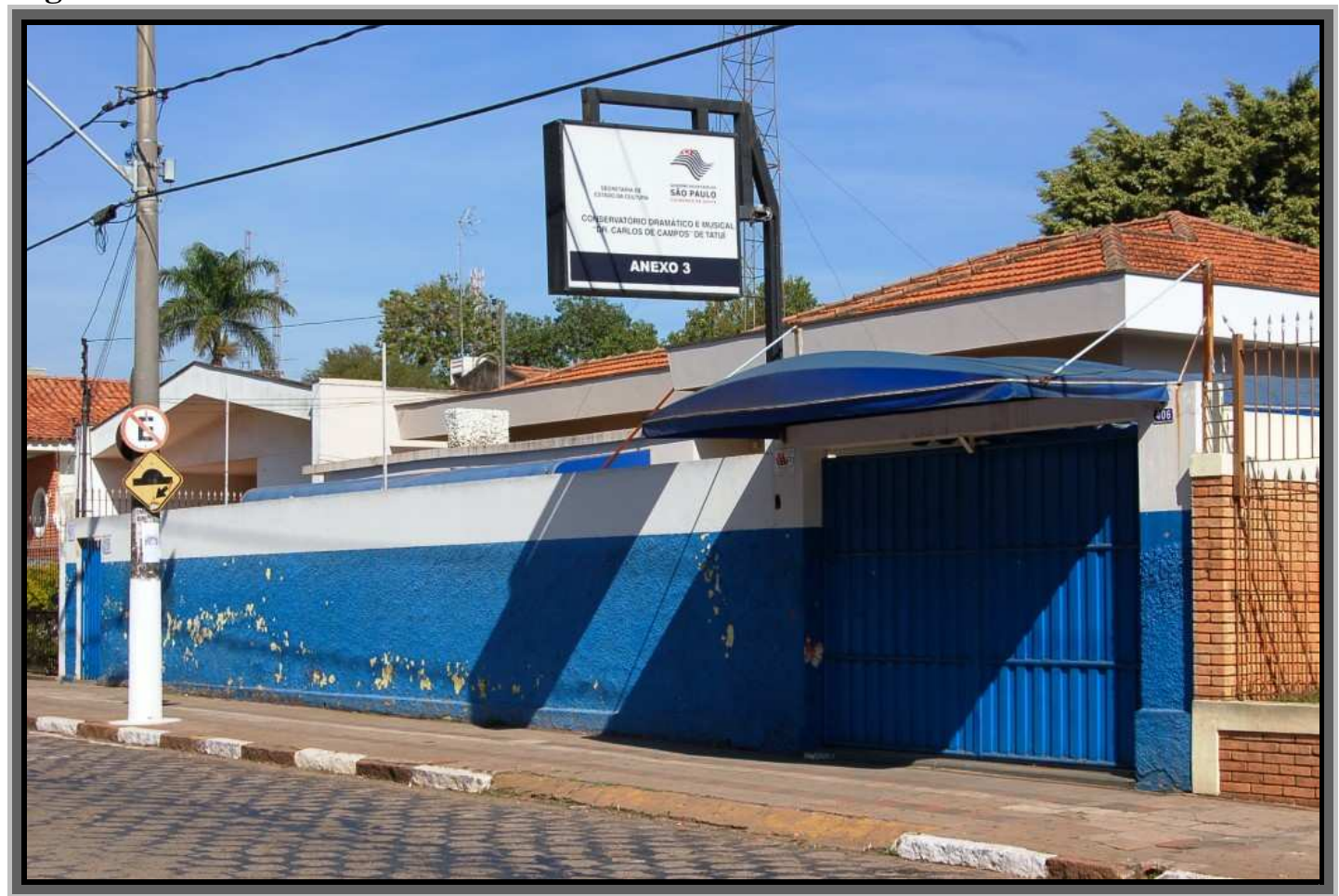

Fonte: Acervo do CDMCC.

${ }^{15}$ LIMA, Sonia Regina Albano de Escola Municipal de Musica-Criação e Desenvolvimento. Tese de Doutorado. P. 99. 
Figura 68 - Anexo 4.

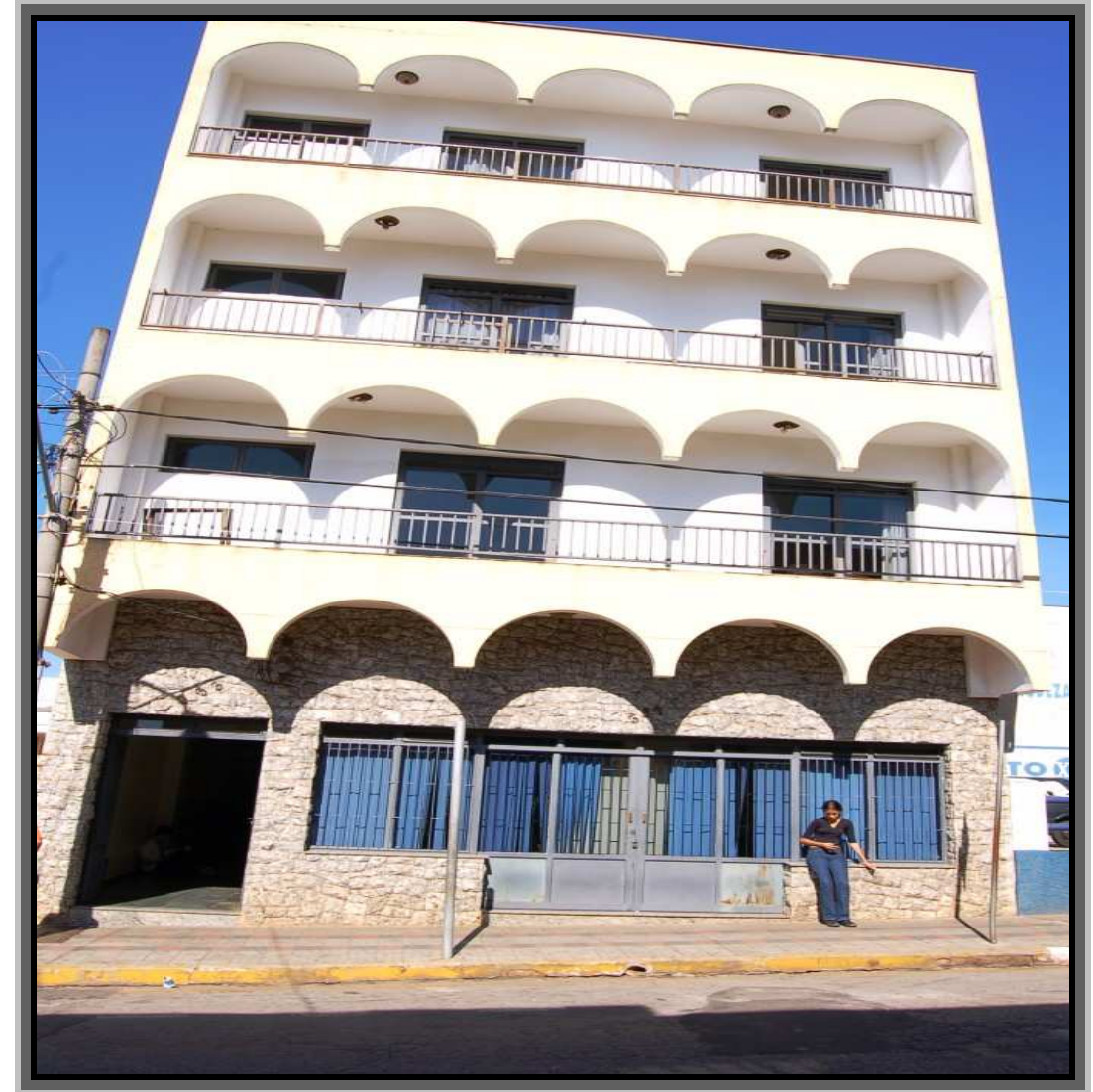

Fonte: Acervo do CDMCC.

Figura 69-Anexo 5.

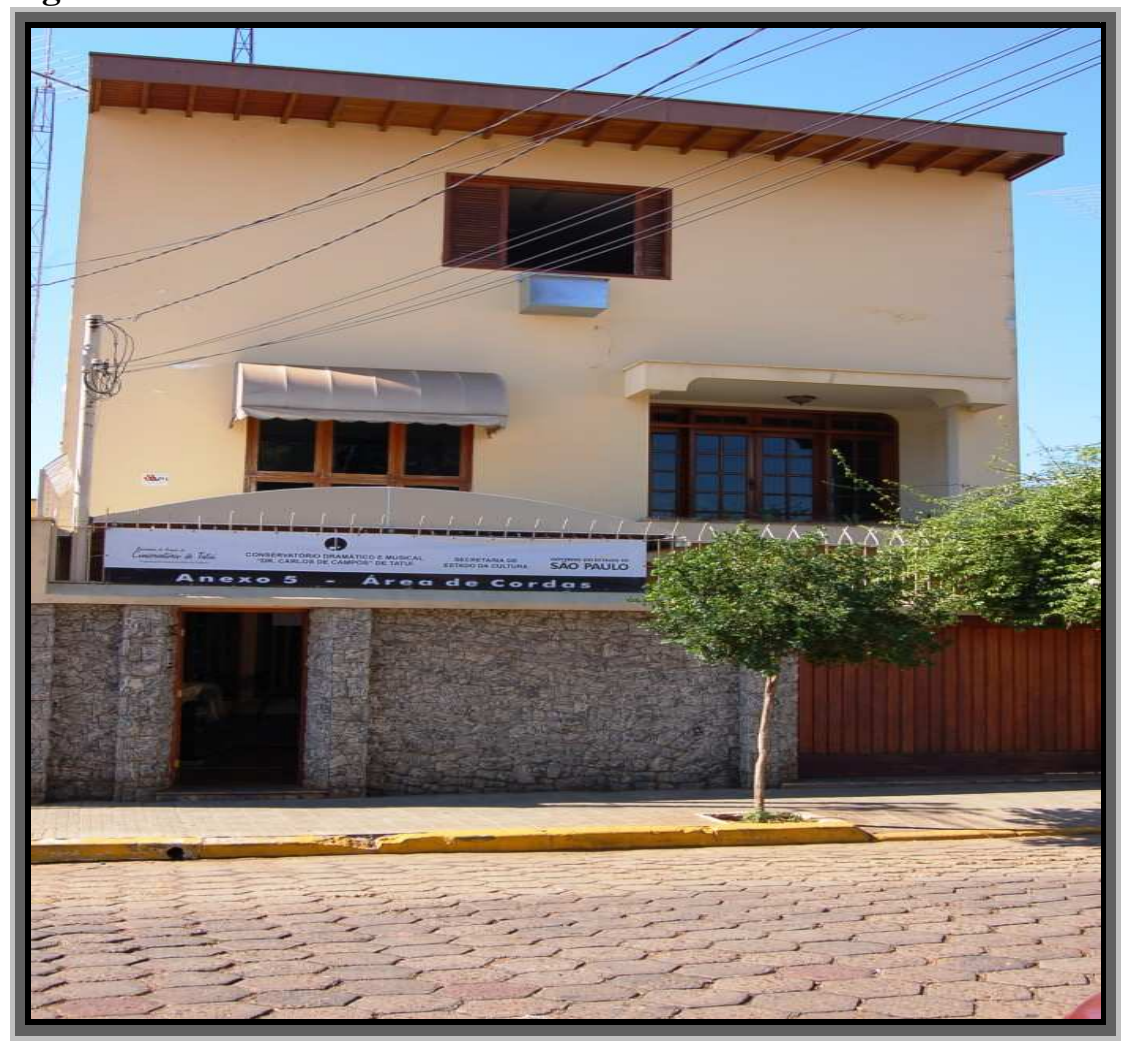

Fonte: Acervo do CDMCC. 
Figura 70 - Anexo 6.

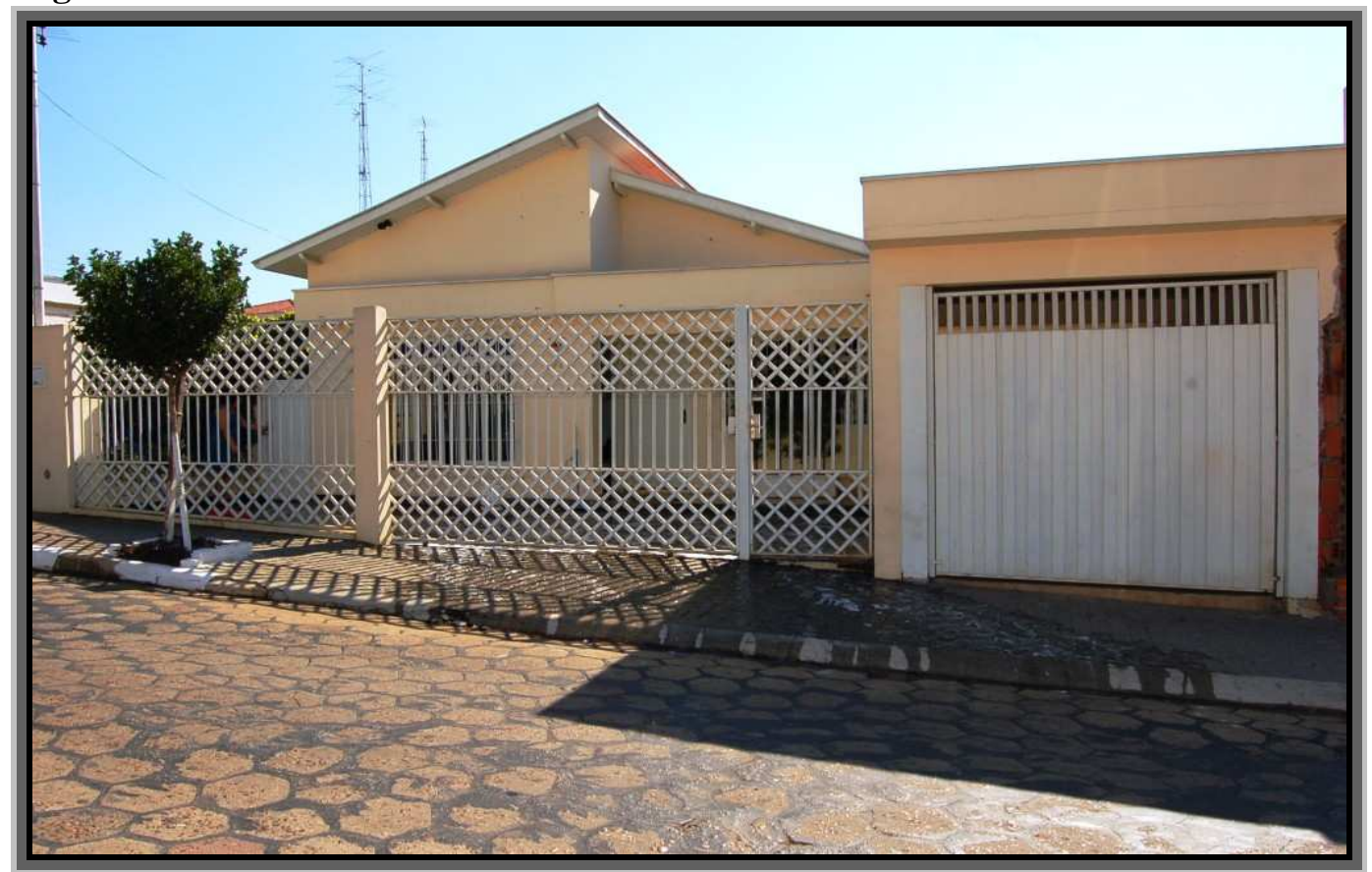

Fonte: Acervo do CDMCC.

Cabe problematizar aqui situações de engessamento de uso de espaço físico como vêm ocorrendo no caso do CDMCC de Tatuí, que não consegue crescimento necessário e fundamental, pelo fato de estar disposto em um espaço que, parte pertence á Câmara Municipal de Tatuí, conseqüentemente o CDMCC não tem autonomia para realizar ampliações, em contrapartida, ironicamente, em seu entorno podemos observar, por exemplo, um terreno que pertence ao Conservatório, porém foi cedido para a prefeitura para que a mesma pudesse estar utilizando como espaço de lazer esportivo para a população.

Esse Diretor voltou-se a projetos, (Pró-Bandas, Festival de Inverno - Núcleo Tatuí e Campos do Jordão, Festival de MPB, Encontros Internacionais, etc.), que dão "status" imediatistas e se projetam como "vitrines" no cenário político em que o Diretor estava inserido, pois o mesmo, durante seu período de gestão no CDMCC foi vereador e tesoureiro de um partido político da cidade.

Sonia Regina Albano de Lima já havia salientado esta problemática em sua tese:

"As falhas pedagógicas apresentadas justificam-se ao se observar um comportamento usual no ensino brasileiro de valorizar demasiadamente o técnico musical em detrimento de uma ação pedagógica que privilegie igualmente o técnico, o teórico e a critica musical”. ${ }^{16}$

\footnotetext{
${ }^{16}$ LIMA, Sonia Regina Albano de Escola Municipal de Musica-Criação e Desenvolvimento. Tese de Doutorado. P. 102 .
} 
"O homem é um animal suspenso em teias de significados que ele mesmo tece ao longo de sua existência social e histórica".

(Geertz) 


\section{CAPÍTULO VI}

\section{A MÚSICA, A CULTURA E OS VALORES: UMA ANÁLISE SOBRE AS ORGANIZAÇÕES CULTURAIS CRIATIVAS E AS BUROCRÁTICAS}

\section{O Conceito de Cultura Organizacional}

De um "ethos" social, vamos recortar o conceito de cultura organizacional, entendida como um grupo de pessoas composto por especialistas que trabalham em conjunto em uma tarefa comum. No estudo das organizações, a cultura equivale ao modo de vida da organização em todos os seus aspectos: idéias, crenças, costumes, valores, regras, técnicas, entre outros. Nesse sentido, todos os seres humanos estão mergulhados na cultura e dela são dotados, pois fazem parte de algum sistema cultural.

A cultura organizacional, ou cultura corporativa, é o conjunto de hábitos e crenças estabelecidos através de normas, valores, atitudes e expectativas partilhadas pelos seus membros e transmitida de geração em geração. Constitui o modo institucionalizado de pensar e agir que existe em uma organização. A cultura organizacional representa as percepções dos dirigentes e funcionários da organização e reflete a mentalidade que predomina na organização. Por esta razão, ela condiciona a administração das pessoas. Para Edgar Schein (1986:155):

\footnotetext{
"Cultura organizacional é o conjunto de pressupostos básicos que um grupo inventou, descobriu ou desenvolveu ao aprender como lidar com os problemas de adaptação externa e integração interna e que funcionaram bem o suficiente para serem considerados válidos e ensinados a novos membros como forma correta de perceber, pensar e sentir em relação a esses problemas".
}

Os elementos formadores dessa cultura organizacional criam normas que definem os comportamentos na interação entre seus membros, os quais são desenvolvidos e reforçados com o decorrer do tempo, influenciando no comportamento e no aprendizado coletivo. Muitas vezes implícitos, emergem ao longo do tempo e reforçam certas normas ou valores e explicam por que razão um dado aspecto da cultura é tão importante para aquele grupo social naquele 
momento histórico. Nesse ambiente, as organizações tendem a imprimir às sociedades em que estão inseridas valores corporativos próprios e, portanto, a cultura corporativa passa a modelar o contexto cultural da região.

O conceito de burocracia dentro da sociologia de Max Weber ${ }^{17}$ o primeiro pensador a realizar uma análise ampla e sistemática do papel social da burocracia, considera-a como forma legítima de domínio. Segundo ele, são três as características da burocracia: a estruturação hierárquica, o papel desempenhado por cada indivíduo dentro da estrutura e a existência de normas reguladoras das relações entre as unidades dessa estrutura. Para Weber, a característica básica de todo o sistema burocrático é a existência de determinadas normas gerais e racionais de controle, que regulam o funcionamento do conjunto de acordo com técnicas determinadas de gestão, visando o maior rendimento possível, podendo ser aplicada a qualquer tipo de situação e contexto.

A influência weberiana na conceituação de estrutura está presente nos seus conceitos usuais que focam, prioritariamente, as suas dimensões formais, ou seja, a divisão do trabalho, a formulação de normas e procedimentos e a distribuição de autoridade. Apesar de a estabilidade ser um importante aspecto da estrutura, o cotidiano organizacional é mais complexo e exige a superação de análises que não consideram a realidade como socialmente construída. Assim, situações não previstas no arcabouço estrutural exigem a interpretação contínua das normas, originando ações não prescritas nos padrões normativos.

Para que normas e comportamentos sejam reforçados, deve-se compreender a necessidade de alguma ordem, no interior da organização. Esta ordem é garantida pela burocracia.

O termo burocracia é largamente empregado com uma conotação negativa que indica, de forma crítica, normas e regulamentos que sufocam a iniciativa e até mesmo a eficácia e a eficiência das organizações públicas e privadas. Outra concepção é a da administração baseada em normas, funções específicas e atribuições de competências bem delimitadas, que designa um modelo específico de organização administrativa e seu papel é organizar e, sobretudo, controlar a execução do trabalho.

Conforme a Enciclopédia Britânica do Brasil,

"Nas ciências sociais, a noção de burocracia define, por um lado, a estrutura organizativa e administrativa das atividades coletivas, no campo público e

\footnotetext{
${ }^{17}$ Max Weber trata da burocracia em obras como: “A Ética Protestante e o Espírito do Capitalismo" e "Ciência e Política: Duas Vocações”.
} 
privado, e, por outro, o grupo social constituído pelos indivíduos dedicados ao trabalho administrativo, organizado hierarquicamente, de forma que seu funcionamento seja estritamente regido por rigorosas regras de caráter interno, emanadas da legislação geral administrativa." (Enciclopédia Britânica do Brasil, CD, edição 2000).

A divisão do trabalho em áreas especializadas é obtida pela definição precisa dos deveres e responsabilidades de cada pessoa, considerada não individualmente, mas como um "cargo". Essa definição de cargo delimita determinadas áreas de competência, que não podem ser desrespeitadas em nenhuma hipótese, de acordo com os regulamentos considerados pertinentes. Em situações extremas ou anômalas, recorre-se à consulta "por via hierárquica", ao órgão imediatamente superior.

$\mathrm{Na}$ realidade, as organizações burocráticas, que são geralmente no campo da administração pública, apresentam normas reguladoras com características negativas, isto é, delimitam e sufocam a iniciativa criadora, impondo determinados valores sociais.

\section{A Música Como Produção Cultural}

Todas as culturas conhecidas desenvolveram sua própria música, mas somente algumas línguas têm uma palavra específica para ela. Assim não é fácil definir música, ainda que historicamente a maioria das pessoas tenda a reconhecer o conceito de música e definir se um determinado som é ou não musical.

Música é um modo de comunicação humano, a música pode ser evocativa, ligada a sentimentos, a visões de mundo, a funções, à história pessoal de cada compositor ou à mitologia de cada grupo social, assumindo funções e revelando valores. Portanto ela não existe isolada das pessoas para as quais ela tem um significado, ela não existe desligada da vida.

A música é um objeto tanto estético quanto histórico. Por um lado possui uma relativa autonomia nos seus aspectos universais; por outro dependente de conceitos, valores e escolhas determinadas por grupos sociais distintos. Devemos deixar que ela mesma nos aponte as direções para sua análise e crítica. Num sentido mais amplo, a música pode expressar os valores sociais centrais de uma sociedade.

Segundo o historiador Henry Raynor, (1986:09):

"O fazer musical, de uma forma ou de outra, sempre esteve presente nas sociedades, desde as mais primitivas [sic.] até as atuais. Quer seja uma 
manifestação estritamente social, ou também artística, expressa de forma coletiva ou individual, (a música só pode existir na sociedade), e com isso está aberta a todas as influências que a sociedade pode exercer, bem como às mudanças de crenças, hábitos e costumes sociais".

O fenômeno musical não pode ser apenas compreendido através de seus elementos musicais, de sua sonoridade, mas também através das características e das condições de quem o produz e de quem o ouve. Em sociedades urbanas como a que vivemos, estas questões tendem a se tornar mais complexas pela multiculturalidade que as caracterizam.

Canclini em sua obra "Culturas Híbridas", (1998:150), afirma que:

"Nessas sociedades as ofertas culturais são muito heterogêneas, justamente por serem fruto da mistura de tradições cultas, populares e massivas, o que gera diversas maneiras de receber e de compreender seus significados".

Desta forma, não podemos atribuir ao fenômeno musical um único significado, principalmente porque a música tem diferentes funções e, em algumas sociedades, certos eventos seriam inconcebíveis sem ela.

A música costuma ser definida como a arte que trata da combinação de sons com o fim de produzir um artifício que possua beleza ou atrativo, que siga algum tipo de lógica interna e mostre uma estrutura inteligível. No interior de cada música podem coexistir diferentes estratos, que se distinguem pelo grau de aprendizagem, o nível social e a maneira de difundi-la, oralmente ou através dos meios de comunicação, etc.

Max Weber, em seu livro Os Fundamentos Racionais e Sociológicos da Música, discute a racionalização do material sonoro e, traçando um paralelo entre a música ocidental e a oriental, aponta para uma racionalidade exterior das formas tradicionais, dando como exemplos a formação sonora com um ou dois sons rítmicos em culturas distintas como a dos patagões, a música eclesiástica bizantina e o antigo canto coral das sinagogas dos judeus sírios (Max Weber, 1995:83). O autor ainda reflete sobre o modo específico através do qual a música inseriu-se no mundo, porém o principal foco é examinarmos a música como um sistema cultural no contexto das organizações sociais criativas.

Mais adiante, em outro contexto, veremos como Merriam e Nettl consideram a questão da definição da música e sua função. 


\section{A Música: Cultura Organizacional Criativa}

A relação da cultura musical, sua estrutura organizacional, seu papel constitutivo nos aspectos da vida social e seu amplo poder analítico explicativo entram na dificuldade das definições de cultura musical. A música desempenha um papel importante em todas as sociedades para se compreender o que é cultura organizacional criativa.

Antes de considerarmos a música como produto cultural socialmente valorizado, é conveniente fazermos algumas considerações conceituais. Pierre Bourdieu (1992:271) aponta que "a transmissão cultural faz com que o capital cultural volte às mãos do próprio capital cultural"; ou seja, Bourdieu trata a arte como um bem simbólico. Isso é fundamental, pois a arte somente terá existência para aqueles que possuírem meios para sua apropriação, isto é, só se constituirá em bem simbólico para os que detiverem o código de interpretação dos símbolos em questão. Nesse sentido, os elementos que preenchem determinados critérios musicais passam a ser significativos para a definição do estilo de vida de um determinado grupo, repercutindo as abordagens weberianas citadas anteriormente e as de Bruno Nettl, que veremos adiante.

Mas o que está em jogo aqui não é somente a música como um sistema cultural simbólico, mas também sua constituição como patrimônio universal da humanidade, que reconhecemos como atividade insubstituível em suas dimensões ônticas e ontológicas, ou seja, no ser em si e em seus traços humanos comuns.

A música sugere, perturba e surpreende por sua singularidade sonora e, mesmo dentro do contexto da leitura de partitura, a música ainda apresenta singularidades nas diferentes culturas, apesar de paradoxalmente, nos parecer uma linguagem universal.

No atual sistema de cultura musical, uma das questões que devem ser pensadas é a da construção do habitus, que Bourdieu (1980:171) define como aquilo que caracteriza uma classe ou um grupo social em relação aos outros que não partilham das mesmas condições sociais:

"[...] os habitus são sistemas de disposições duráveis e transponíveis, estruturas estruturadas predispostas a funcionar como estruturas estruturantes, isto é, a funcionar como princípios geradores e organizadores de práticas e de representações que podem ser objetivamente adaptadas a seu objetivo sem supor que se tenham em mira conscientemente estes fins e o controle das operações necessárias para obtê-los [...]". 
Por representar a interiorização da exterioridade e a exteriorização da interioridade em práticas sociais exclusivas, mas comunicantes, o referencial metodológico de Pierre Bourdieu, no que diz respeito às escolhas determinantes dos habitus seria de grande utilidade para esse tipo de análise.

\section{Organizações Culturais Criativas}

A criatividade é um tema que faz parte do contexto atual das organizações. Aquelas que pretendem substituir o paradigma da sobrevivência pelo paradigma da expansão precisam se reinventar. Segundo De Masi (1999:14) em seu livro “A Emoção e a Regra”, um grupo pode ser chamado criativo quando tem a habilidade de inventar, imaginar, transformar a realidade ou realizar algo de novo ou original ou de resolver problemas, no universo das artes e das ciências.

As organizações criativas são constituídas de pessoas com capital intelectual, capital imaterial, composto de ativos intangíveis que precisam ser mantidos e desenvolvidos.

Os grupos analisados pelo autor "haviam elaborado o seu modelo original de organização" (De Masi, 1999:18), fato que, podemos dizer, ocorreu na fase inicial do CDMCC de Tatuí e que posteriormente teria seu modelo organizacional gerenciado pelo Estado.

\section{O Conservatório Dramático e Musical "Dr. Carlos de Campos” de Tatuí como Modelo Organizacional Criativo}

O Conservatório Dramático e Musical "Dr. Carlos de Campos” de Tatuí, pólo dinamizador da produção cultural brasileira e de intercâmbio cultural, no qual o aprendizado da música é o "produto" principal, pode ser considerado como modelo de criatividade organizacional. 
Conforme De Masi (1999:19), na fenomenologia dos grupos criativos:

"As habilidades intelectuais e a preparação rigorosa dos indivíduos são exaltadas por um forte envolvimento emotivo e, quase sempre, por uma admirável correção profissional, além de um forte senso de união por pertencer ao mesmo grupo".

O CDMCC de Tatuí deu início à sua própria experiência a partir do conhecimento das dinâmicas transformadoras contemporâneas, dedicando-se no curso de muitos anos à afirmação e difusão da música. Em tal obra de difusão, particular preocupação foi dedicada à organização dos professores e dos grupos musicais nos quais estão reunidas contribuições do trabalho, das organizações e da sociedade pós-industrial.

Não conseguimos determinar até agora se o CDMCC de Tatuí adotou algum sistema advindo dos inúmeros conservatórios que, desde a década de 1920, se constituíram no estado de São Paulo, mas, de qualquer modo, seu processo institucional se desenvolveu de maneira sui generis, constituindo-se pouco a pouco como uma referência na formação de músicos.

Como organização pertencente à Secretaria da Cultura, ele sofre interferências administrativas implantadas pela administração pública. Neste sentido, as alterações estruturais sofridas por esta organização visavam, muitas vezes, à conformação aos aspectos técnicos e legais estipulados pelos órgãos competentes ligados a uma estrutura social maior. Entretanto, apesar das pressões contextuais serem percebidas como condicionais para se alterar a estrutura, sua ocorrência estará sempre vinculada aos padrões simbólicos colocados pela instituição, como princípios mediadores da interpretação e da ação frente a estas pressões que geram valores.

As instâncias políticas devem continuar a apoiar e patrocinar os sistemas culturais. Atualmente, o Estado surge como o sujeito, o iniciador de uma política cultural nova, inserida num novo contexto nacional, em que a importância da educação e da formação artísticocultural da população é posta em destaque. No que se refere à educação, a questão aponta para uma perspectiva da igualdade de acesso à cultura, já que é por essa via que todos podem receber a sua herança cultural comum e transformá-la. Conforme o sociólogo Denys Cuche

“... na construção cultural, o que vem primeiro é a cultura de grupo, a cultura local, a cultura que liga os indivíduos em interação imediata uns com os outros, e não a cultura global da coletividade mais ampla." (1999:107).

Inicialmente é necessário criar oportunidades para que o cidadão além de conhecer a sua própria cultura, tenha a oportunidade de interagir com a sua cultura e com a cultura global da coletividade mais ampla. 
Em matéria de formação, o primeiro passo é preparar quadros capazes de corresponderem às solicitações do mercado e às características do público-alvo. De fato, é preciso saber apoiar, alargar e estimular a procura cultural na sociedade através da educação dos jovens e da formação de quadros especializados nos conteúdos da gestão cultural.

Figura 71-Visão noturna do Teatro Procópio Ferreira.

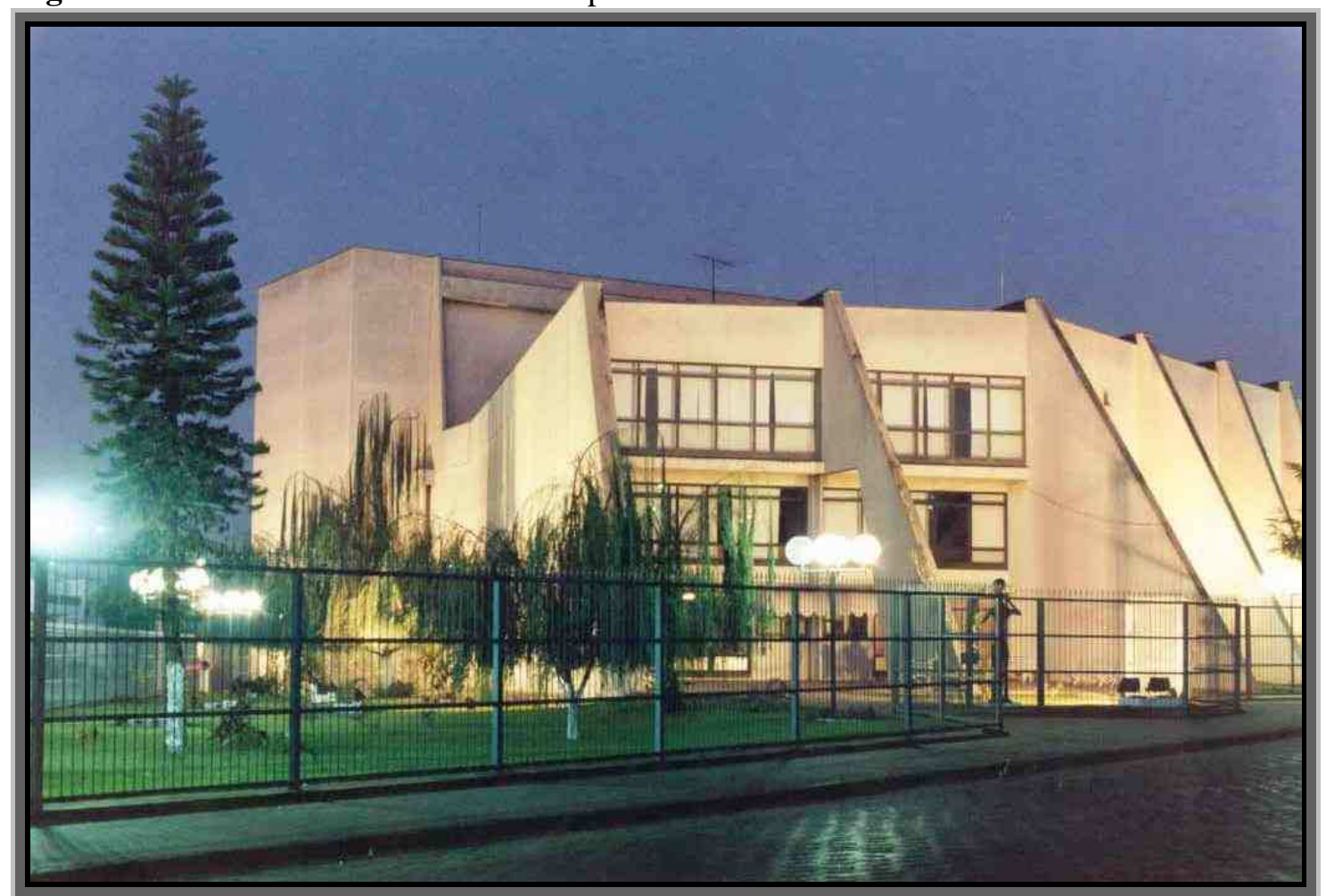

Fonte: Acervo do CDMCC de Tatuí. 
Figura 72 - Escultura feita pelo prof. Josué F. Pires.

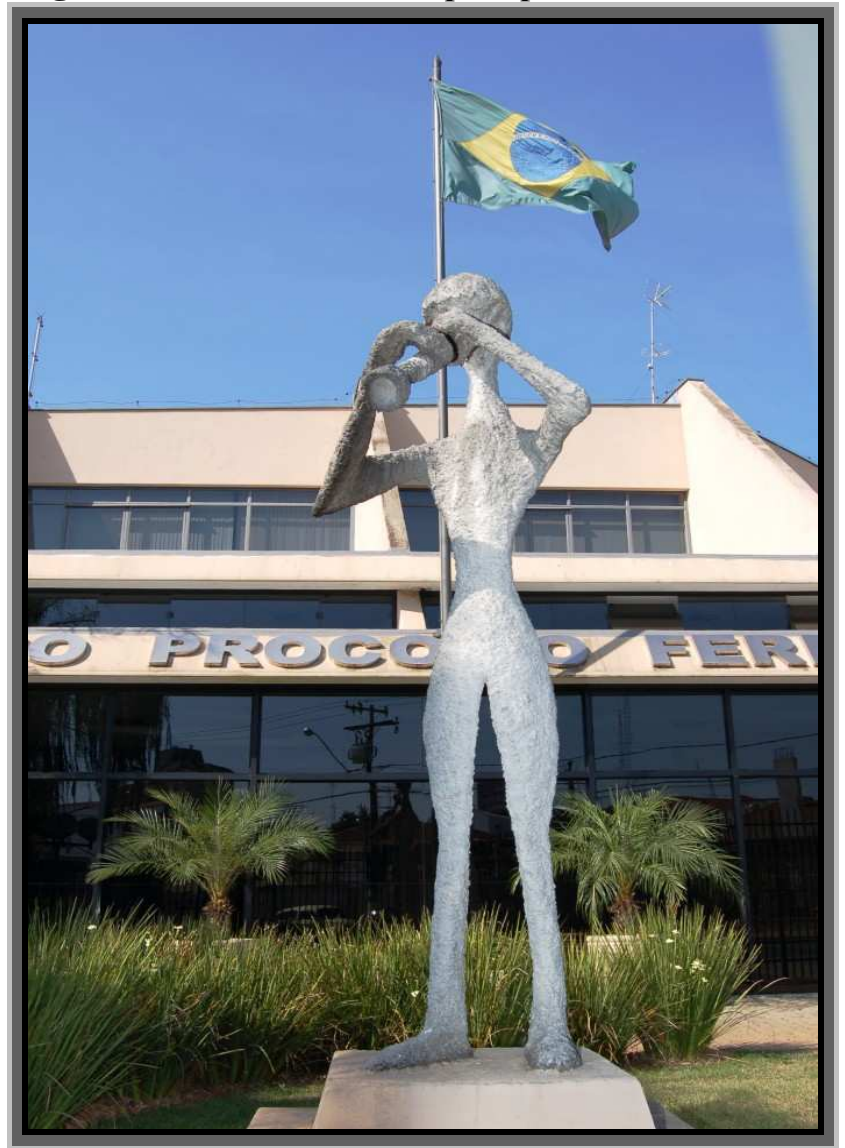

Fonte: Acervo do CDMCC de Tatuí.

Figura 73 - Alunos do CDMCC do ano letivo de 2009.

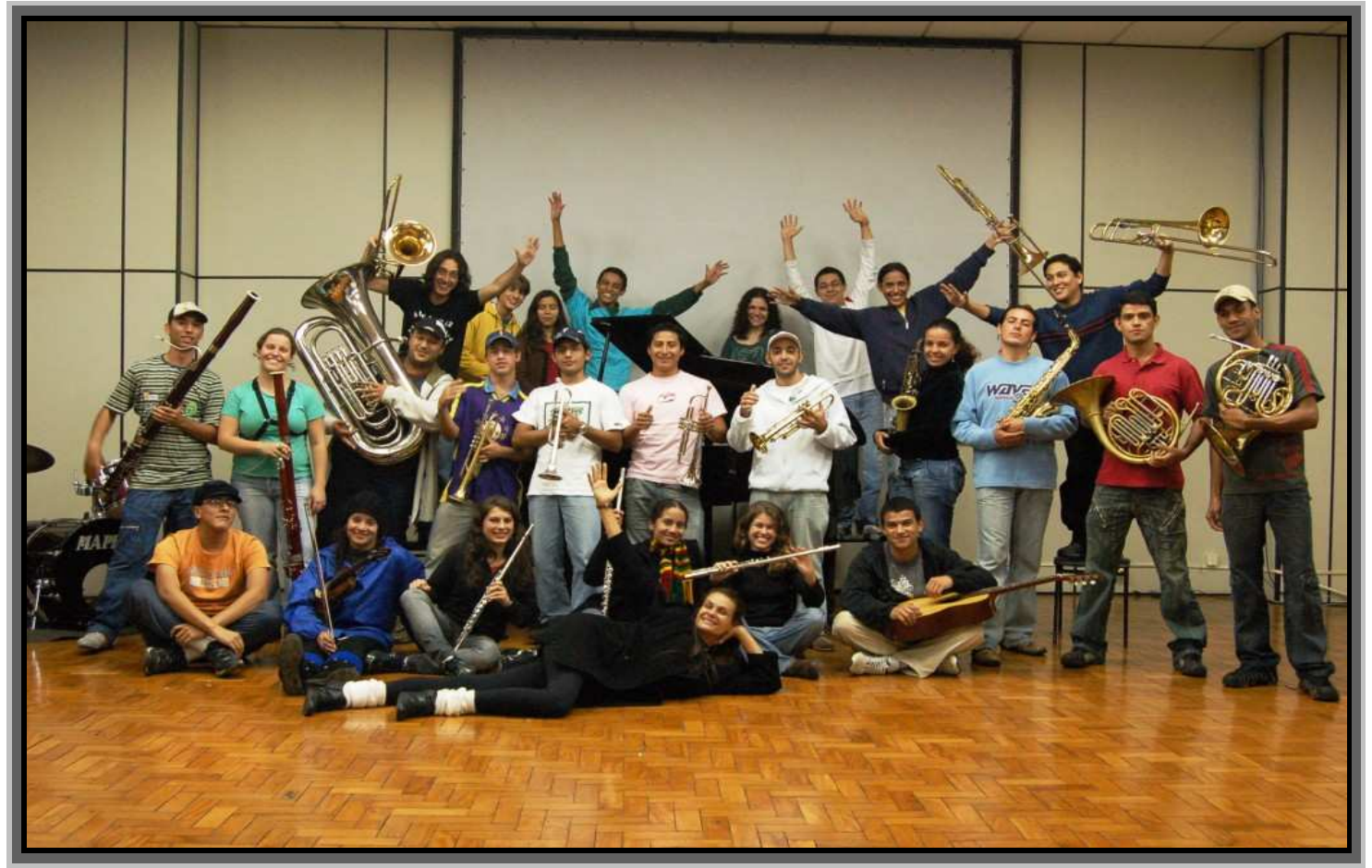

Fonte: Acervo do CDMCC de Tatuí. 


\section{A Estrutura Didática do CDMCC}

Pensar sobre educação é antes de tudo um ato de humildade intelectual, que exige o diálogo com outras áreas do conhecimento. Comenius, considerado pai da moderna pedagogia diz em sua Didáctica Magna que:

"Ensinar a arte das artes é, portanto, um trabalho sério e exige perspicácia de juízo, e não apenas de um só homem, mas de muitos, pois um só homem não pode estar tão atento que não lhe passem despercebidas muitas coisas".

No século atual, indivíduos e poderes políticos tendem a considerar a busca do conhecimento não como um fim em si mesmo, mas como um meio para um alargamento do humano. Dentro desse contexto, o papel do professor é imprescindível, que se irá lhe exigir muito, pois depende dele, em grande parte, a concretização desse propósito coletivo. Nesse panorama, em que se entrecruzam a ação coletiva e a ação individual, o papel do professor é também estabelecer ligações em rede com outros profissionais, outras disciplinas, outros papéis. Sobre isso, Danilo Streck ressalta que:

\footnotetext{
"A educação tem a ver com a medida que damos a homens e mulheres, tem a ver com o sonho que alimentamos em relação à sociedade. Por isso a tentativa de compreender a educação ultrapassa os limites de uma área de conhecimento ou disciplina acadêmica. A reflexão sobre a educação é, pela própria natureza do objeto, uma atividade inter ou transdisciplinar."
}

Dentro dessa percepção estaremos nos debruçando primeiramente sobre o desenvolvimento da pedagogia no CDMCC. Ao falar de educação musical no CDMCC abrese um leque de reflexões. Embora seja uma instituição que, até os dias atuais, ainda não concretizou a elaboração de um projeto político pedagógico, e que se sujeita a um regulamento instituído em 1971, o CDMCC conseguiu sobrepor-se ao estigma do fracasso tornando-se um referencial de ensino dentro de sua modalidade.

Não há no Conservatório de Tatuí um curso voltado à Docência em Música, embora esteja no regulamento de 1971, Artigo 2.0 parágrafo 3: "O Grau Geral tem por finalidade formar instrumentistas, coristas, cantores, professores, e dará diploma aos alunos que concluírem os cursos" (Grifo nosso). Grande parte do corpo docente do CDMCC não tem Licenciatura ou ao menos possui Bacharelado, sendo, na sua maioria, pessoas que se formaram músicos no próprio CDMCC, e que se aventuraram na área docente. Dentre estes, poucos buscaram uma continuação em sua formação acadêmica. 
Como já foi mencionado, o CDMCC é regulamentado até hoje pelo mesmo Decreto №. 52.687, de cinco de Março de 1971, período em que o Brasil era governado pela Ditadura Militar. Os cursos atualmente oferecidos no CDMCC estão assim divididos: Artes Cênicas, Canto e Coral, Choro, Cordas, Educação Musical, Luteria, Matérias Teóricas, MPB\&JAZZ, Musica de Câmara, Percussão, Performance Histórica, Piano, Regência, Sopros-Madeiras, Sopros-Metais, Violão Erudito.

No dia 16 de fevereiro de 1955, o Conservatório realiza sua primeira reunião ordinária, promovendo a estruturação pedagógica, de acordo com regulamento do novo órgão diretivo, o Conselho Técnico Administrativo do Conservatório de Tatuí (CTA). Esse órgão do Conservatório de Tatuí, composto por professores eleitos a cada dois anos e tendo como presidente o diretor do Conservatório de Tatuí, teve sua existência aprovada por decreto $\mathrm{n}^{\circ}$ 23.238 de $1^{\circ}$ de abril de 1954. Os primeiros professores eleitos foram Luis Cartolano, Marina Tereza Fillardi, Zita Alves do Amorim e Judith C. de Oliveira.

Nessa reunião, fica parcialmente decidida a grade curricular, no sentido de dar uniformidade ao curso de Teoria e Solfejo e os programas de Harmonia Elementar, Psicologia Musical, História da Música, e dos cursos de flauta, clarineta e demais instrumentos de madeira.

Somente nos cursos de piano e cordas é que houve uma base curricular direcionada nos moldes do currículo da Escola Nacional de Música da Universidade do Brasil (piano) e no Conservatório Municipal de São Paulo (cordas). Nas demais áreas não houve consenso, ficando a cargo de cada professor deferir e aplicar o seu próprio método de ensino, portanto não havendo uma estrutura pedagógica segundo uma mesma finalidade educacional em todas as áreas. Os programas seguiram até 1971 de forma experimental, quando, a pedido do então Diretor José Coelho de Almeida, foi solicitada a revisão e unificação do conteúdo programático das áreas, de maneira que pudesse ser aplicado de forma mais objetiva e eficaz e que estivesse mais próximo da realidade musical nacional. 
Figura 74 - As três primeiras alunas formadas no curso de piano.

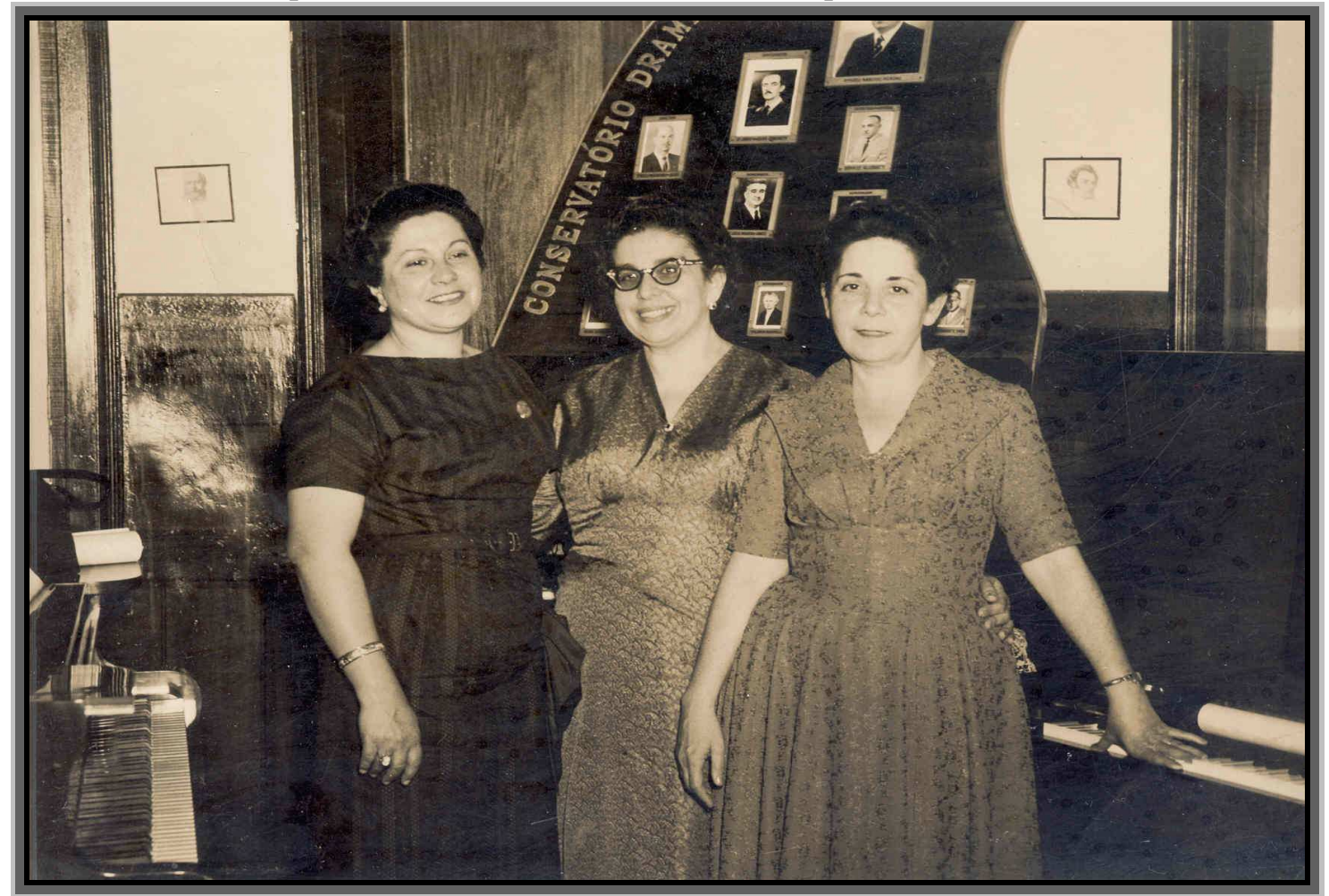

Fonte: Acervo do CDMCC.

Com o passar dos anos, a desistência de vários professores e a necessidade de atualização da estrutura curricular, as áreas foram adquirindo uma indesejável autonomia que as levaram a reformular seus conteúdos como clãs isolados, ou seja, sem uma supervisão pedagógica que as orientasse a partir de uma proposta pedagógica geral e de valores sóciomusicais.

Hoje, os programas estão estruturados em níveis, auxiliando dessa forma o trabalho do professor em sala de aula. Mas, embora cada área elabore o seu próprio conteúdo, permitindo uma maior autonomia, a falta de um consenso pedagógico evidencia uma pratica exclusivista de determinadas áreas sem uma maior interação. Assim, é flagrante a necessidade de uma proposta político pedagógica para a instituição. Se observarmos no regulamento de 1971, não encontramos sequer a missão que esta instituição deve prestar à sociedade.

Desse modo, algumas áreas têm suas especificidades contempladas em um currículo e outras nem mesmo isso têm. Mas como é então que o CDMCC foi e ainda é uma referência no campo do ensino de música no Brasil ou até mesmo fora dele? O que parece digno de se esperar é, ao menos, um apontamento para superações mesmo que parciais, indicando rumos por onde a prática pode se estruturar para então se re-estruturar. 
Para elucidarmos a questão, utilizaremos o planejamento da área de cordas devido à sua relevância estrutural como campus representativo que é dentro do CDMCC. O planejamento da área de cordas é o resultado de uma somatória de experiências de alunos e professores que passaram por ela, disse em depoimento pessoal o professor de viola Carlos Blassioli. Ele ressalta que o conteúdo da área começou a apresentar resultados após a vinda do professor e violinista Paulo Bosísio, que desde 1980 vem dando suporte técnico e artístico. Bosísio era considerado pela maioria como o mentor da área, pois antes de sua vinda, que ocorreu a convite do então Diretor José Coelho de Almeida, poucos resultados a área tinha obtido.

As propostas feitas na área de cordas apontam para a associação entre atividades sistemáticas de ensino e de pesquisa. O programa tem os seguintes objetivos principais:

- Domínio da técnica geral, o que envolve um completo controle de ambos os braços, permitindo que o aluno venha a conseguir executar todos os efeitos sonoros requisitados pelo repertorio;

- Processos interpretativos nos diferentes estilos e períodos musicais, permitindo ao interprete expressar-se artisticamente por meio de seu instrumento;

- Tornar o aluno auto-suficiente consiste no desenvolvimento da capacidade de resolver racionalmente eventuais problemas técnicos durante a execução de uma composição.

O plano de trabalho da área de cordas visa a desenvolver talentos que no sentido de possibilitar ao aluno integrar-se nas áreas de Ensino, Orquestras Sinfônica, solistas, conjuntos de câmara. O conteúdo programático está assim divido:

- Preparatório (dois anos), para alunos sem conhecimento específico do instrumento, no qual o curso visa a iniciar princípios básicos de colocação, empunhamento do arco e introdução da leitura musical e rítmica. Sugestões de horários de estudo diário do instrumento;

- Módulos Básico I, Básico II (dois anos), aprofundar a compreensão dos mecanismos básicos de mudanças de posições, movimentos básicos anatômicos de braço direito e esquerdo, fatores de sonoridade, sincronização, afinação, entonação e material técnico relacionado a cada etapa vencida. Introdução ao repertório específico de cada instrumento levando o aluno a praticar a técnica aprendida;

- Módulos Intermediário I, Intermediário II, (dois anos), ainda trabalhando nos aspectos acima citados; será também cobrado do aluno um maior domínio da técnica de mão direita associado ao conhecimento dos princípios de fraseologia, para tal são acrescentados diferentes golpes de arco e também, quando necessário, o uso do vibrato e suas combinações; 
- Módulos Avançado I, Avançado II (dois anos), dando continuidade ao seu desenvolvimento como instrumentista de cordas, nesta fase o aluno já estará participando de grupos de câmaras, necessitando assim de um maior aprimoramento de toda técnica. Para tal será cobrada uma sonoridade mais apurada, que, embora seja em parte pessoal, possui uma infinidade de matizes que devem ser dominados em todas as suas graduações e timbres;

- Módulos Aperfeiçoamento I e Aperfeiçoamento II (dois anos), é um módulo facultativo. Para o aluno entrar nesse módulo, parte-se do pressuposto de que o mesmo tenha alcançado um bom nível técnico de seu instrumento, aprimorando seus conhecimentos, possibilitando-lhe adentrar o acesso ao repertório virtuosístico. Durante o curso, o aluno se apresentará como camerista e também se preparará para apresentações como solista, juntamente com uma das orquestras da escola, consolidando assim seu desenvolvimento artístico, técnico e musical.

O currículo escolar está dividido em matérias teóricas e de prática instrumental, dando sempre ênfase à performance. O repertório e os métodos a serem desempenhados pelos alunos seguem um programa estabelecido em cada instrumento, respeitando suas especificidades. As aulas seguem um programa pré-determinado aliado às necessidades artísticas e técnicas de cada aluno, pois existe uma gama relativamente grande para cada nível, com peças e métodos adequados, sempre visando à formação de instrumentistas, cameristas, ou até mesmo solistas.

As avaliações são realizadas em cinco etapas: quatro avaliações bimestrais e uma avaliação geral realizada no final do ano letivo. Para as avaliações bimestrais, os alunos devem apresentar um estudo - que consta no conteúdo programático de cada área definido entre o professor e o aluno, e um trecho de uma obra que o mesmo esteja estudando naquele momento. Para a avaliação final, o aluno deverá executar o material mínimo para exame, exigido no conteúdo programático de cada instrumento, que geralmente não ultrapassa um ou dois estudos, além de um concerto ou uma sonata executada na integra acompanhada ao piano, como demonstra o material abaixo selecionado.

\section{Curso intermediário}

\section{$1^{a}$ Série}

\section{Métodos}

Hans Sitt II ( $4^{\mathrm{a}}$ e $5^{\mathrm{a}}$ posição fixa).

Hans Sitt III (mudança de $1^{\mathrm{a}}$ à $5^{\mathrm{a}}$ posição).

Mazas - estudos especiais op.36 (Galamian). 
Escalas maiores de três oitavas e arpejos maiores e menores de duas oitavas.

Hans Sitt V - cordas duplas.

\section{Repertório}

Rieding - op.24 Sol maior.

Rieding - op.25 Ré maior.

Vivaldi - concerto em Lá menor.

Vivaldi - concerto em Sol menor.

Portnoff - op.14 em Lá menor.

Potstock - Souvenier de Sarasate.

Hans Sitt - op.31 / op.70.

Fiocco - Allegro.

\section{Repertório brasileiro}

Villa-Lobos - Elegia.

Villa-Lobos - Canto do Cisne Negro.

Carlos de Almeida - Dança Brasileira.

Francisco Chiaffitelli - Minuetto.

Francisco Chiaffitelli - Berceuse.

Luis Cosuel - Oração a Teiniaguá.

J. Guerra Vicente - Noturne.

Material mínimo para exame:

Colocação do instrumento e empunhamento do arco em relação ao executante.

Movimentos básicos anatômicos de braço direito:

A.Movimento do braço inteiro.

B.Movimento do antebraço.

C.Movimento de queda e ascensão do cotovelo.

D.Movimento rotacional do antebraço.

E.Movimento de pulso.

F.Movimento de dedos.

Articulação de mão esquerda.

Escalas de três oitavas maiores e arpejos maiores e menores de duas oitavas.

Um estudo na $4^{\mathrm{a}}$ posição fixa, um estudo na $5^{\mathrm{a}}$ posição fixa e um estudo de mudança de posição que inclua as posições estudadas.

Um concerto de $1^{\circ}$ a $5^{\circ}$ posição apresentado na íntegra abrangendo as posições estudadas. 
As aulas Práticas têm a duração de sessenta minutos. As aulas Teóricas (Teoria, Harmonia, Contraponto, História da Música, Orfeão, Coral) são coletivas, com duração de sessenta minutos, todas oferecidas uma vez por semana, com exceção da prática de conjunto, que pode chegar a três vezes por semana.

A prática de conjunto está dividida em grupos pedagógicos constituídos por alunos da escola e por um grupo artístico pedagógico, que é composto por alunos e professores do CDMCC. Atuam em mais de vinte grupos (neste número estão incluídos big band, música de câmara, MPB \& Jazz, orquestras de cordas, orquestras sinfônicas e bandas sinfônicas). A duração mínima diária desta prática é de sessenta minutos, podendo variar para mais tempo de acordo com o nível técnico do grupo. Ao que se sabe, somente em Tatuí e em alguns cantões na Suíça é que temos orquestras onde professores e alunos compartilham de uma mesma experiência, pois tocam lado a lado, exercitando troca de experiências e conhecimentos.

A concentração da prática do professor engloba tanto as dimensões sociais e pessoais quanto a profissional, sendo que esta mantém uma relação de reciprocidade, de pensamento e interação com o meio social. Assim, as experiências, os conhecimentos e saberes que os professores incorporaram ao longo de sua trajetória, constituem seu habitus, ou seja, sua forma de ser, pensar, e agir em sua pratica profissional e social. Isso porque na base da ação do docente, encontra-se a reminiscência, a tradição, entendida como processo de incorporação de crenças, valores e percepções do mundo. Esse habitus servirá então de mediador entre a estrutura e a prática, constituindo-se em uma espécie de matriz de percepções que orienta as ações do professor nas situações que irá enfrentar no futuro (Bourdieu 2004). 
Figura 75 - Grupo de Arte Cênica.

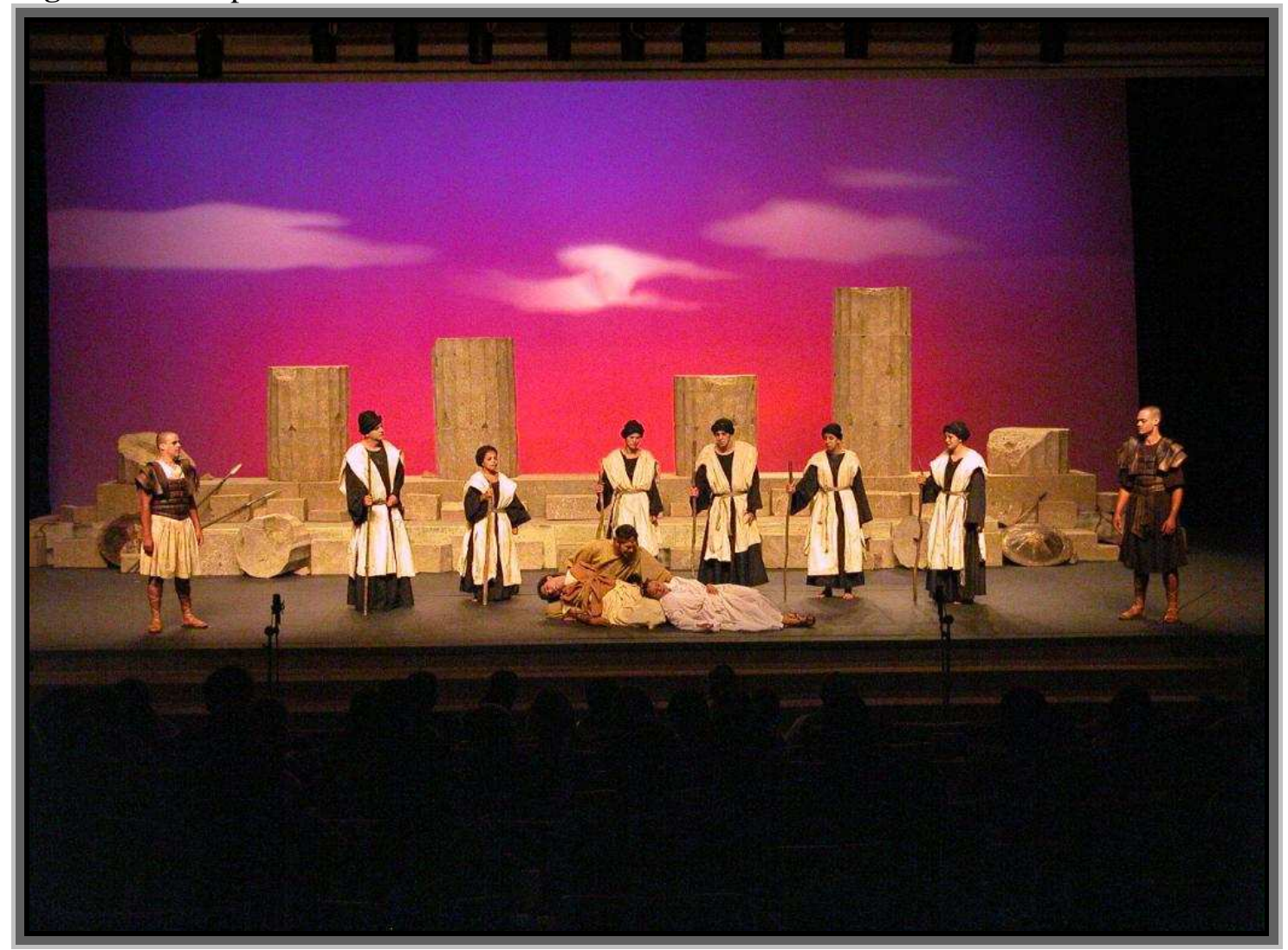

Fonte: Acervo do CDMCC de Tatuí.

Figura 76 -Big Band do CDMCC.

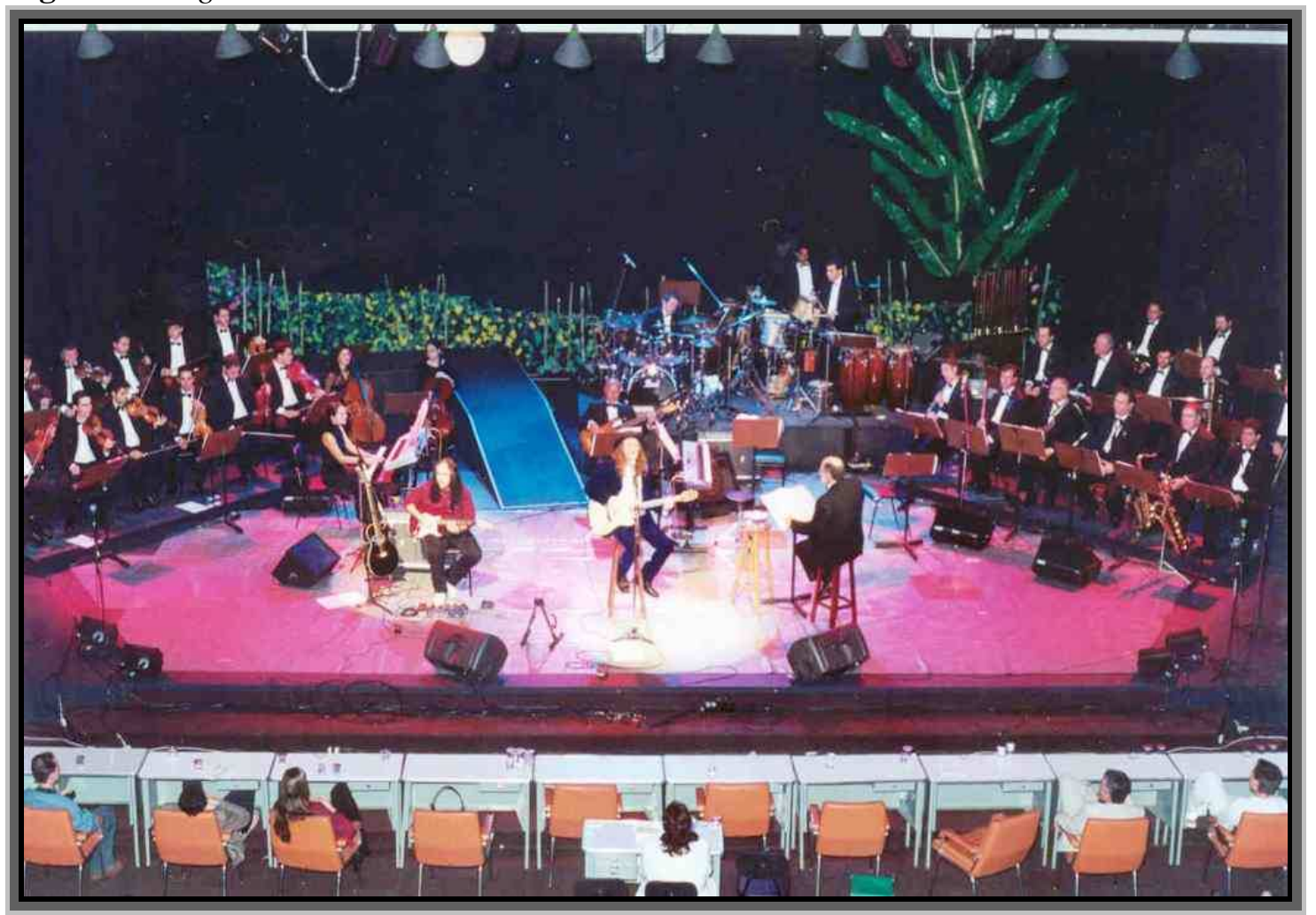

Fonte: Acervo do CDMCC de Tatuí. 
Figura $77-47^{a}$ Semana da Música-Orquestra Sinfônica Jovem-“Coral da Boca pra Fora" Regente Édson Beltrami, 21/11/2007.

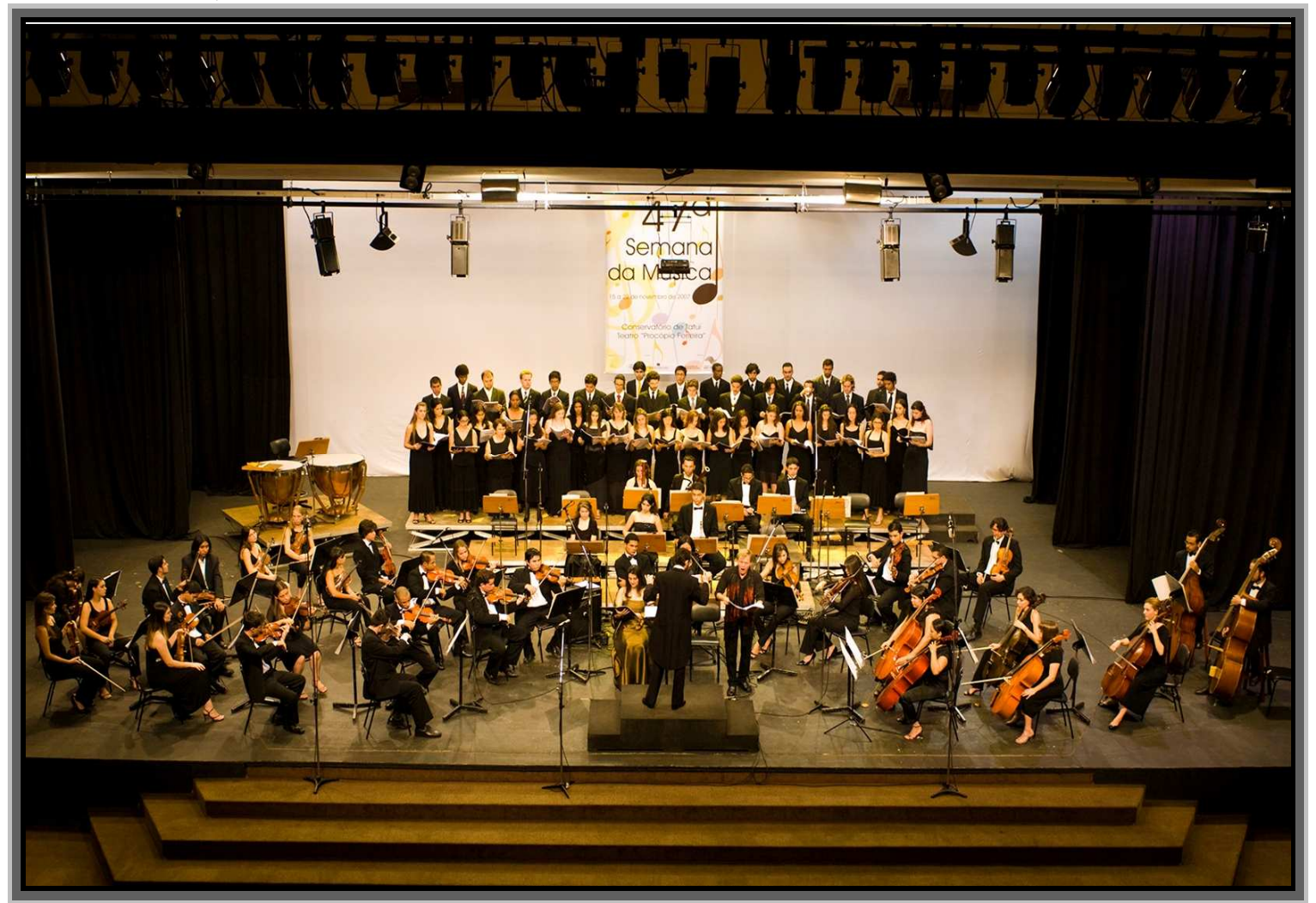

Fonte: Acervo do CDMCC de Tatuí.

Figura 78 - Grupo de Choro "Quebrando o Galho."

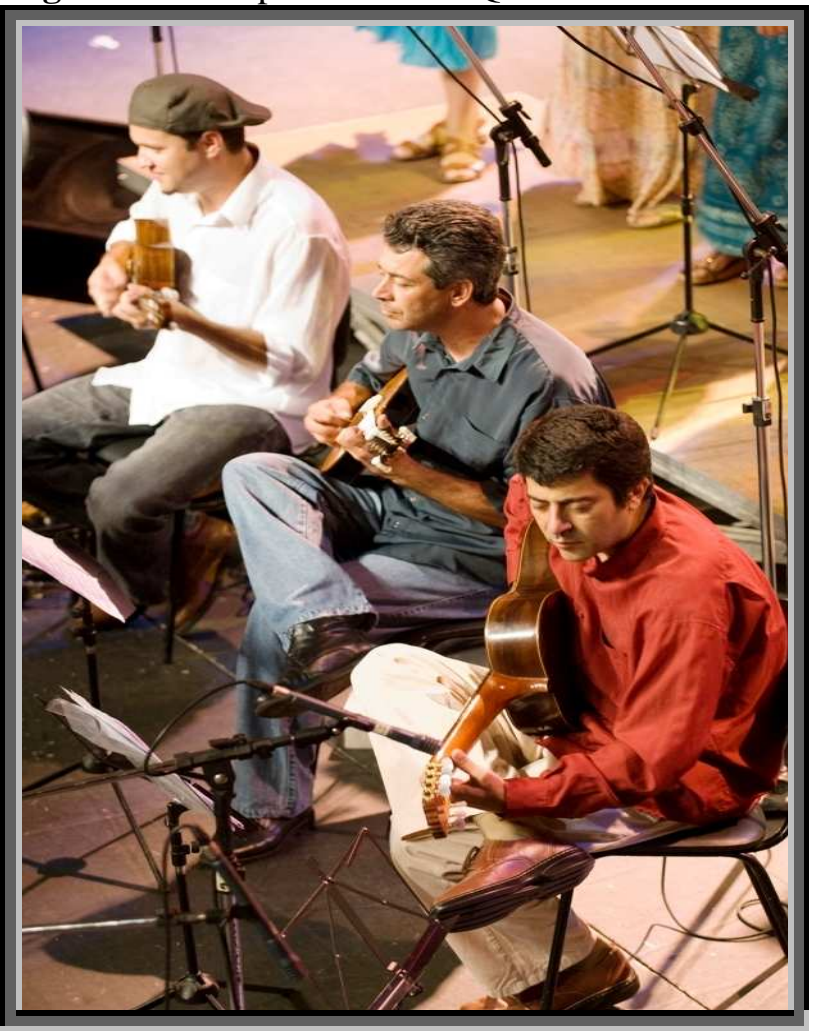

Fonte: Acervo do CDMCC de Tatuí. 
Figura 79 - $47^{a}$ Semana da Música-Orquestra de Cordas Infantil “Da Capo" Solista- Héber Franklin - Regente Donizete Faconi.18/11/2007.

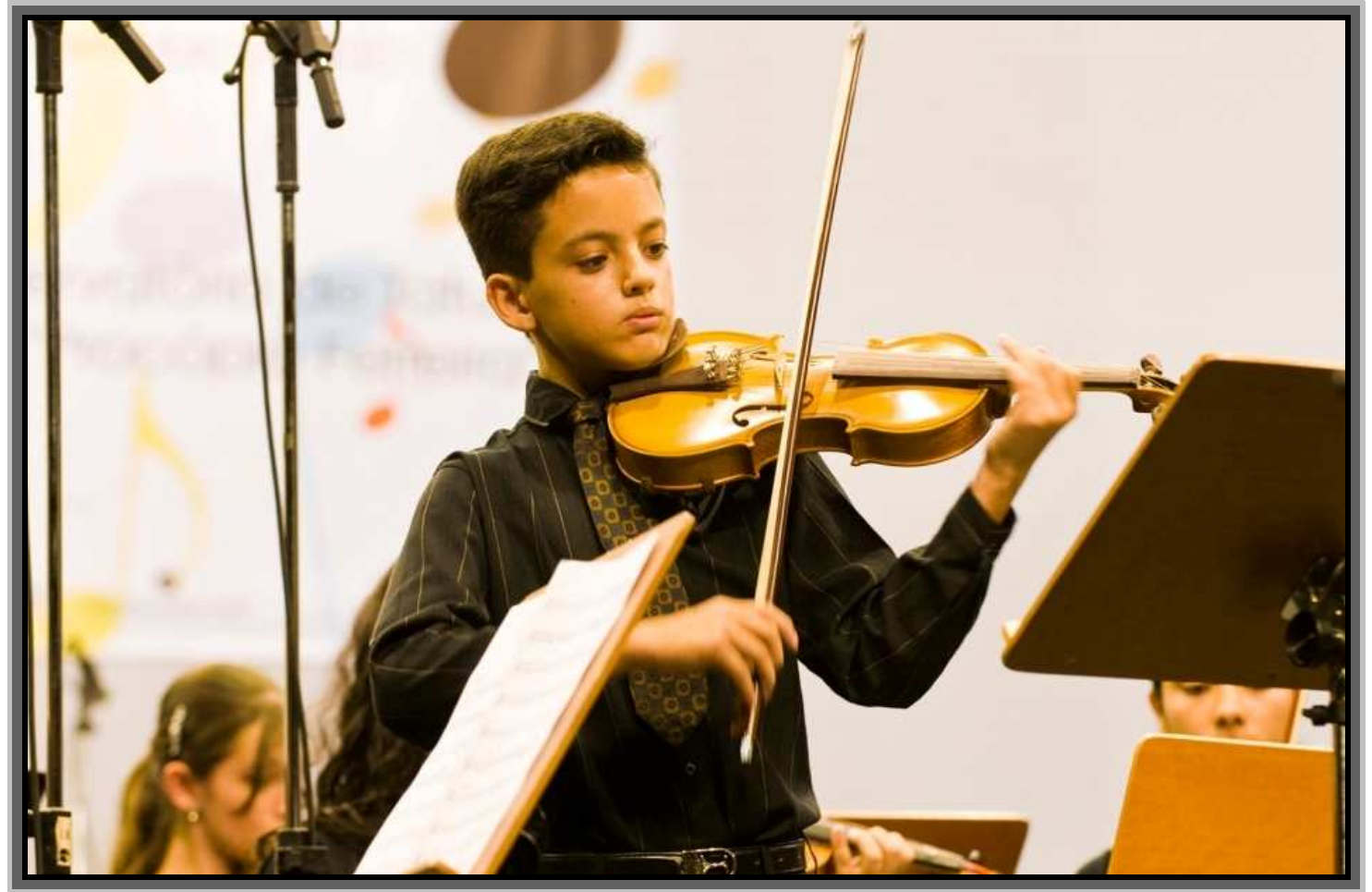

Fonte: Acervo do CDMCC de Tatuí.

Figura 80 - Orquestra "João Del Fiol” Regente - Raymundo Françani -Participação especial da "Banda Sinfônica Jovem" Regente- Antonio Pereira 18/11/2007.

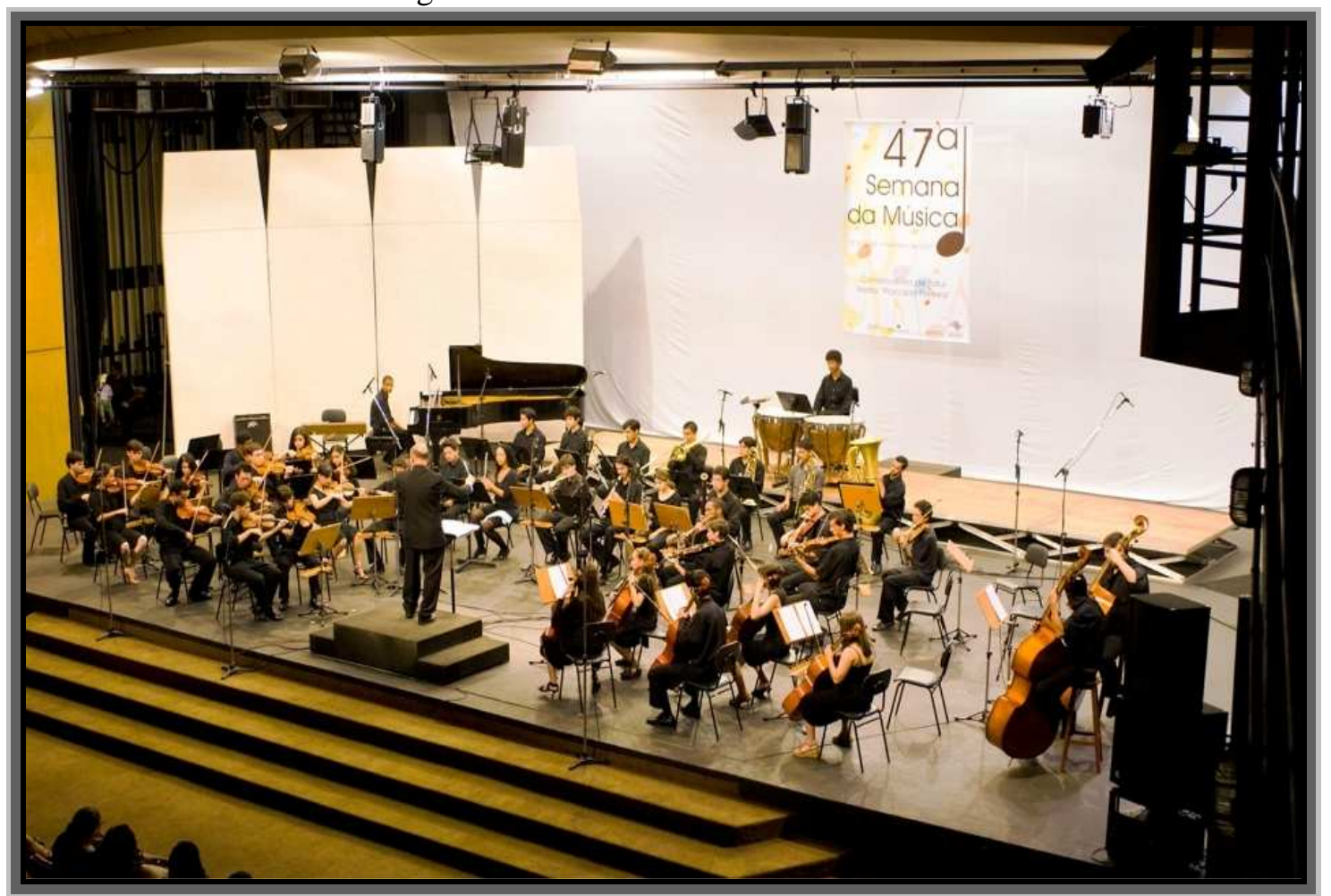

Fonte: Acervo do CDMCC de Tatuí. 
Figura 81 - Alunos do Curso de Luteria-Segurando um tampo de violino no lado direito está o professor Isaias Batista de Oliveira.

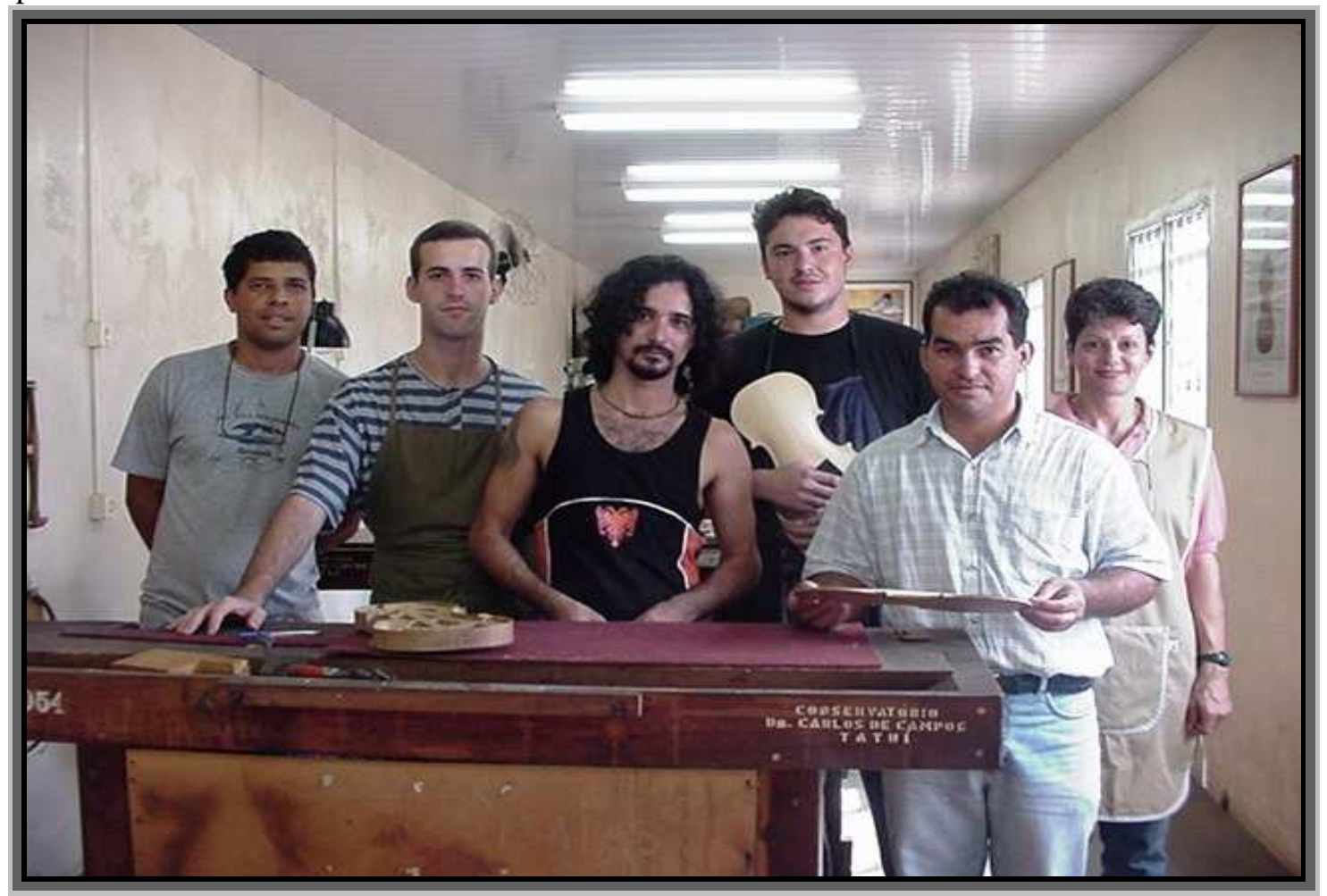

Fonte: Acervo do CDMCC de Tatuí.

Figura 82 - Banda Sinfônica - Solista Deni Feijó-Regente George Mathew 15/11/2007.

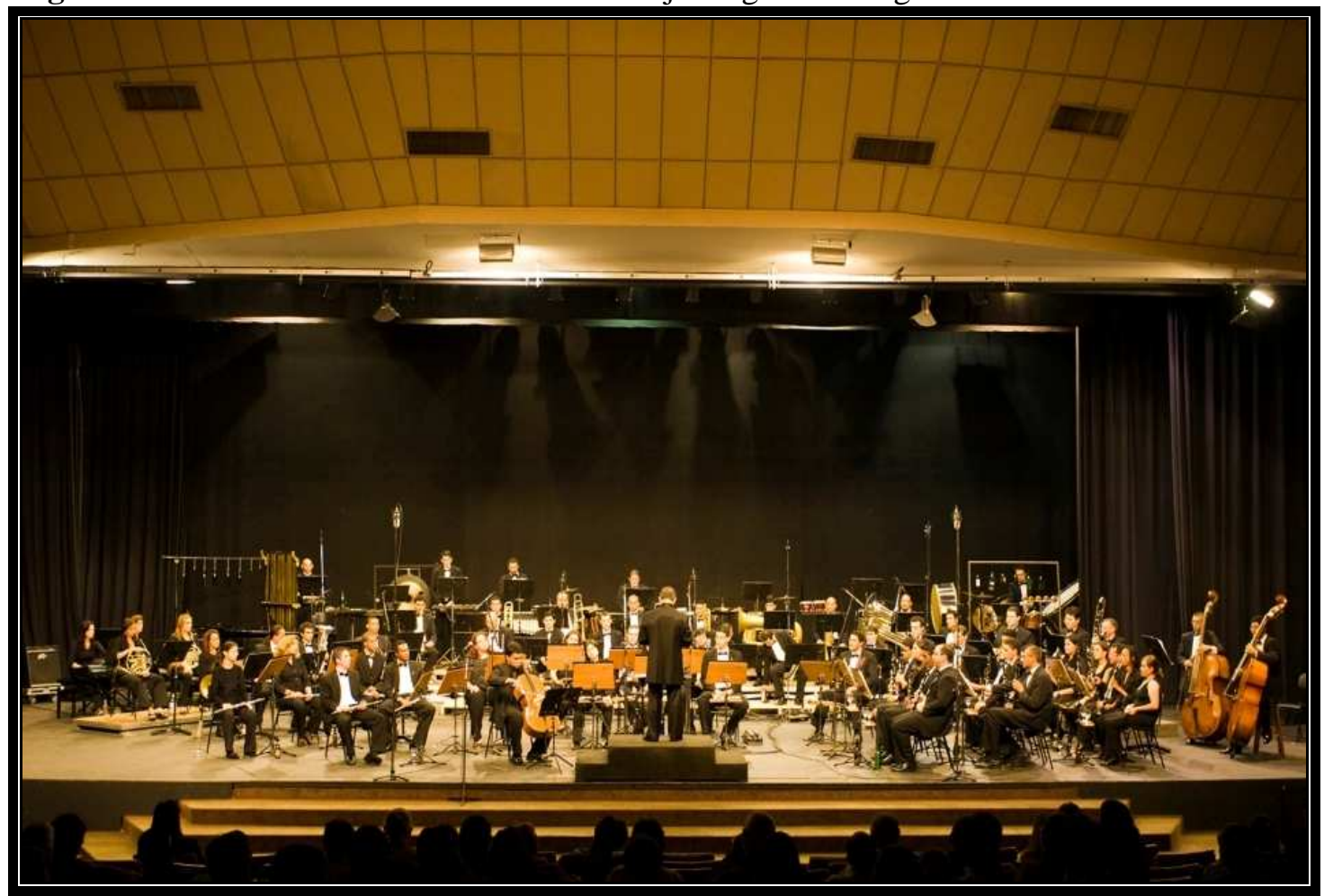

Fonte: Acervo do CDMCC de Tatuí. 
Figura 83 - Big Band Sam Jazz \& Leny Andrade 16/11/2007.

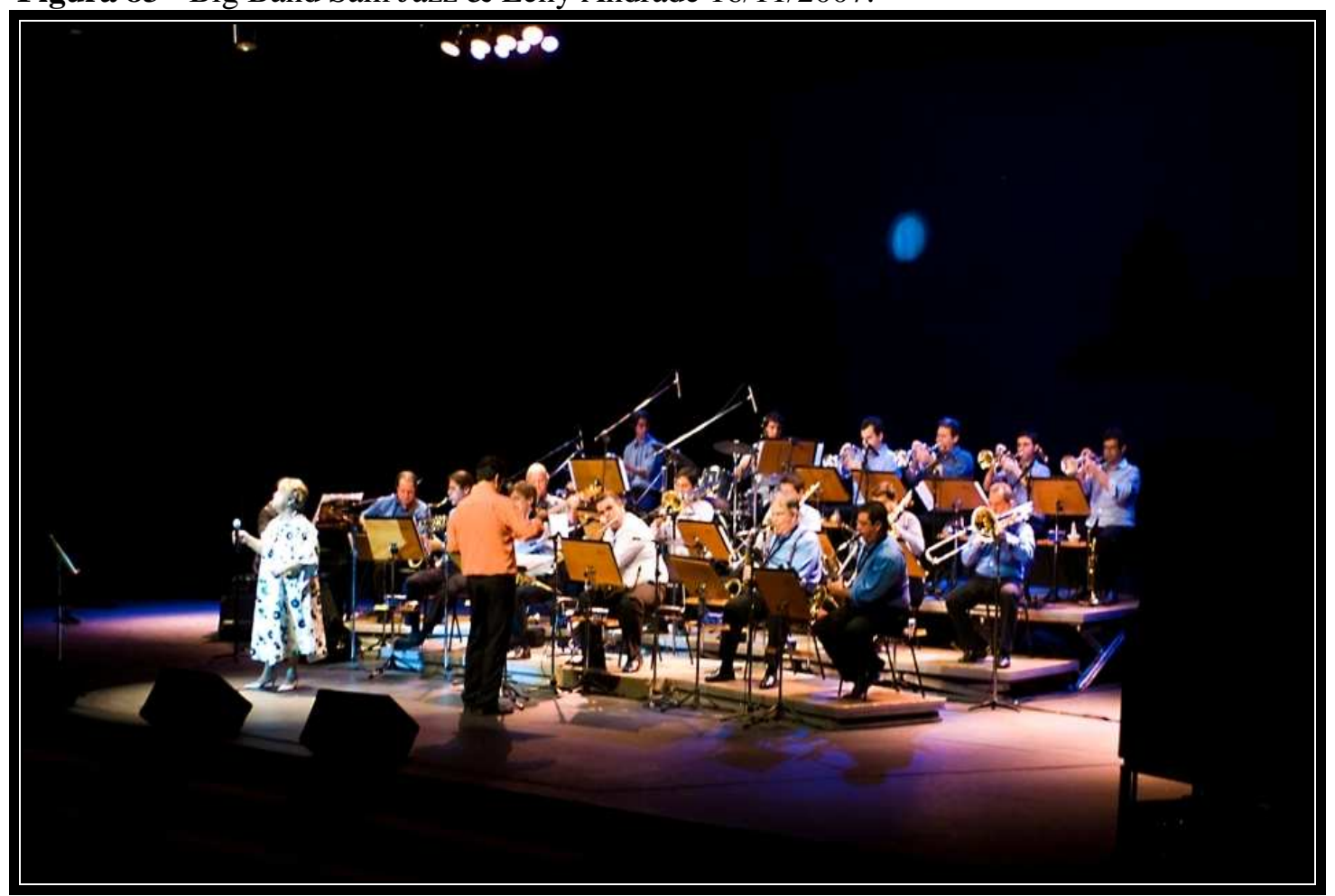

Fonte: Acervo do CDMCC de Tatuí.

Figura 84 - Camerata Octopus-Direção-Édson Lopes.

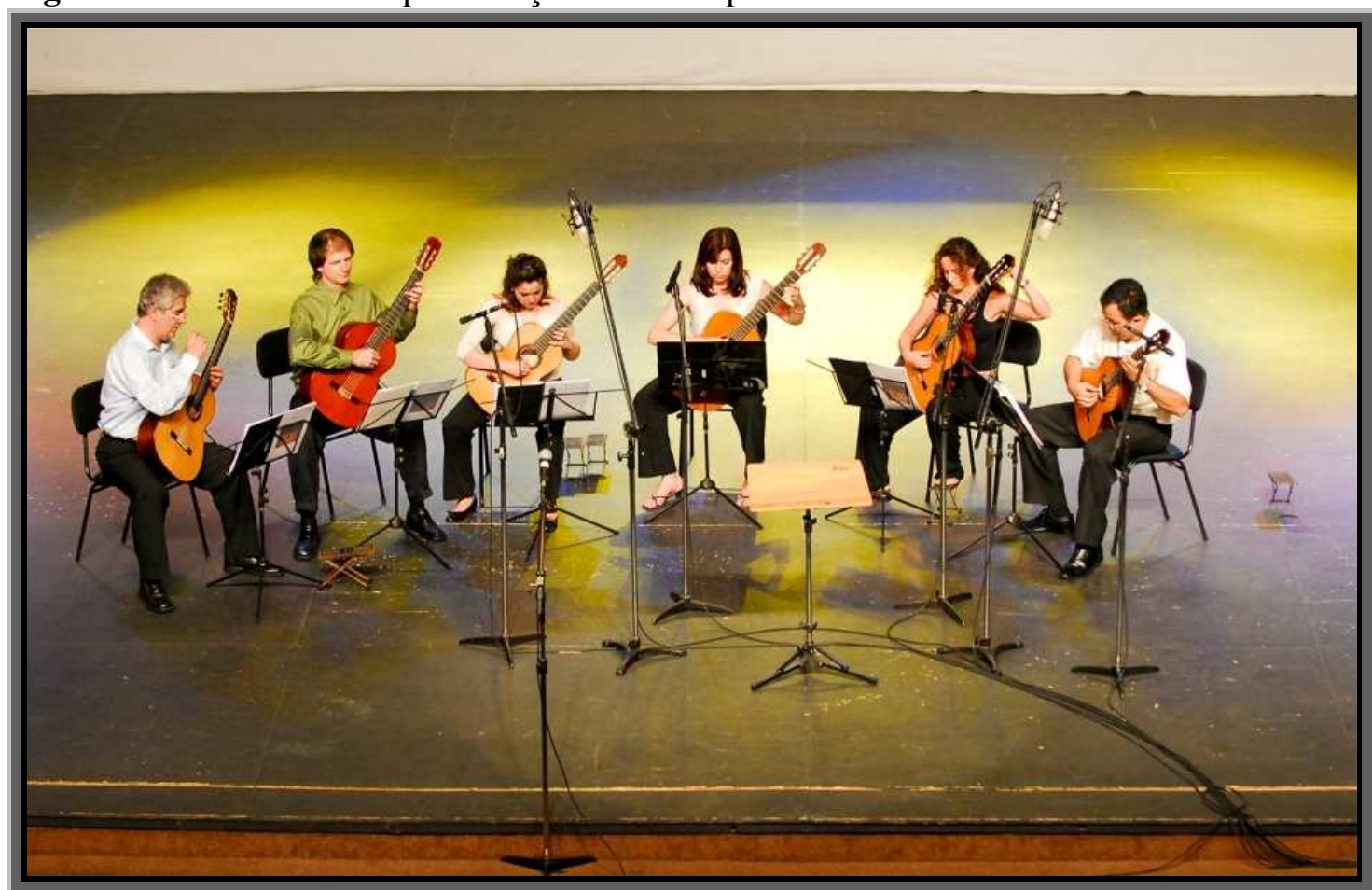

Fonte: Acervo do CDMCC de Tatuí. 
Figura 85 - Orquestra sinfônica do conservatório de Tatuí.

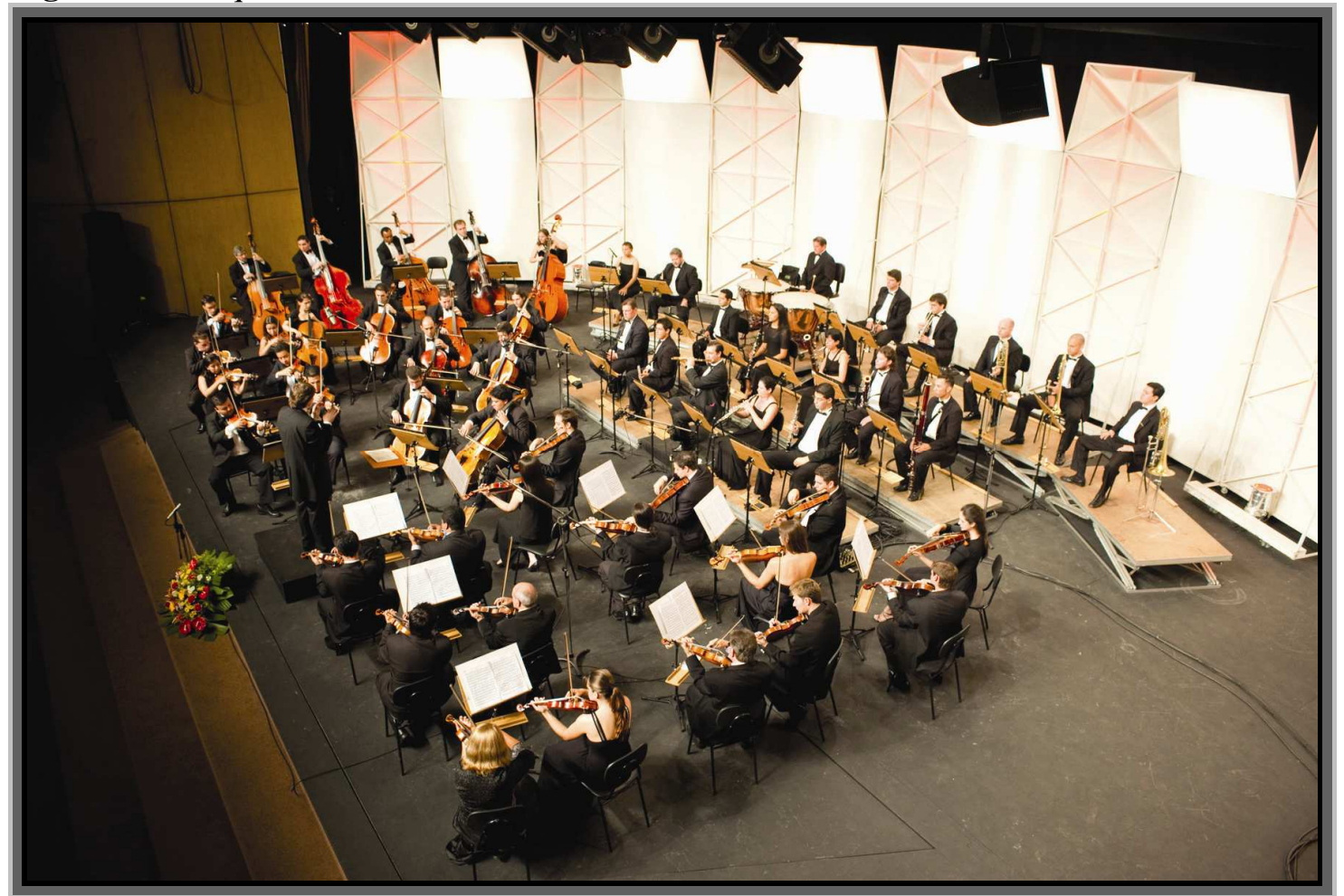

Fonte: Acervo do CDMCC de Tatuí.

\section{Ensinar: uma Arte, uma Ciência - Sentido de Pertencimento}

Atualmente, o CDMCC conta com 203 professores, sendo que a predominância é de professores do sexo masculino ( $72 \%$ são do sexo masculino e $28 \%$ do sexo feminino). Quanto à formação dos professores, 70\% deles têm apenas o Certificado de conclusão do CDMCC, $25 \%$ têm nível superior, não necessariamente em música, e apenas 5\% tem habilitação em música ou uma pós-graduação em áreas diversas, $78 \%$ do corpo docente constituem-se de exalunos que estudaram integralmente ou parcialmente no CDMCC e $22 \%$ em outras instituições.

No início do CDMCC, quase que todo o corpo docente era oriundo de outras localidades. Posteriormente, a situação se inverteu; hoje os professores ou são tatuianos ou moram na cidade, gerando um vínculo completamente distinto com a instituição, culminando no sentimento de pertencimento. Esse sentimento de pertencimento dos professores tem relação com a noção de participação na "construção" da instituição, tanto que o corpo docente já influenciou inclusive na escolha da Direção, mesmo que indiretamente, tornando-se ao longo desses anos a sua espinha dorsal, responsável pelo direcionamento da instituição. 
Na medida em que o grupo se sente ator do processo, o que for sendo construído de forma participativa poderá desenvolver a co-responsabilidade, compartilhando os resultados com o grupo. Assim, haveria um pouco da experiência e vivencia musical de cada um que tenha passado pela instituição na constituição de seu programa.

É possível afirmar que o sentido de pertencimento sob o qual a maior parte desses professores construiu como modelo pode levá-los a uma integração, a qual propiciaria ao indivíduo um corpo comum de categoria de pensamento e ação. Sobre esse aspecto, Bourdieu comenta:

\begin{abstract}
“Tendo sido moldados segundo o mesmo 'modelo'(pattern), os espíritos assim modelados (patterned) encontram-se predispostos a manter com seus pares uma relação de cumplicidade e comunicação imediatas [...]. No seio da cultura clássica, todos os homens possuem em comum um mesmo tesouro de admiração, de modelos, de regras e, sobretudo de exemplos, metáforas, imagens, palavras, em suma, uma linguagem comum". (op. cit.,p. 206).
\end{abstract}

Ao questionarmos alguns dos professores sobre o ingresso na docência, o argumento utilizado para a opção pelo magistério foi a complementação da renda familiar. Isso se justifica em primeiro lugar, pelo restrito número de orquestras profissionais e a baixa remuneração, em segundo lugar pela distinção e hierarquia musical, perpetuada durante os três últimos séculos: maestro, compositor, intérprete, camerista e por fim, músico de orquestra, ou seja, o professor passou a ser uma estratégia para uma ascensão social através de bens culturais e status.

São professores por opção ou pela falta dela, fato que conseqüentemente atinge diretamente sua atuação como docente. Portanto, na construção da sua prática profissional, no conjunto de valores e crenças acumuladas durante a trajetória educacional, entre outros elementos, a didática e o planejamento nem sempre se articulam.

Quando se faz referência a planejamento do ensino, a idéia que passa é aquela que identifica o processo através do qual são definidos princípios, objetivos, conteúdo programático, metodologia, recursos didáticos, avaliação de aprendizagem, bem como a bibliografia básica a ser consultada no decorrer de um curso, série ou disciplina de estudo.

“... o plano de ensino de uma maneira fragmentária e desarticulada do todo social é que tem gerado a concepção de planejamento incapaz de dinamizar e facilitar o trabalho didático. Consideramos, contudo, que uma percepção transformadora, ou seja, o processo de planejamento, visto sob uma perspectiva crítica de educação, passa a extrapolar a simples tarefa de se elaborar um documento contendo todos os componentes tecnicamente recomendáveis."(Repensando a Didática, 1990:43). 
A partir dos desacertos observados na prática pedagógica adotada pela instituição até então, notamos que o processo de planejamento dos professores precisa ser repensado. Percebemos que um planejamento dirigido para uma ação pedagógica crítica e transformadora, e, ainda, articulando os núcleos constituídos e sua visão de música e de educação, possibilitariam ao professor maior segurança para direcionar a relação educativa na escola como um todo.

"Produzir conhecimentos nessa concepção tem o significado de processo de reflexão permanente sobre os conteúdos aprendidos, buscando analisá-los sob diferentes pontos de vista. Significa ainda desenvolver a atitude de curiosidade cientifica, de investigação da realidade, não aceitando como conhecimentos perfeitos e acabados os conteúdos transmitidos na escola" (Repensando a Didática, 1990:43).

Assim, apesar da pulverização da estrutura pedagógica em núcleos pedagógicos desconectados, parte do grupo é qualificada. Pertencendo ao complexo institucional, os professores recebem digamos um aval vitalício, uma autonomia de decisão para criarem e difundirem seus "modelos pedagógicos". Agregados a um forte senso de pertencimento à instituição, constituem uma maior valorização de seu habitus, gerando porém, através desse sistema peculiar de ensino, um distanciamento entre uma maioria de instrumentistas em processo de capacitação e uma minoria de instrumentistas em adiantado aperfeiçoamento, reforçando muitas vezes, talvez inconscientemente, a idéia exclusiva de dom e talento.

Sobre essa inconsciência, há muito que a sociologia e a antropologia da música discutem a consciência de seus usos e funções. Hoje, entende-se que, a aparente inconsciência com relação às funções da música em uma determinada sociedade esconde um sistema de valores plenamente consciente, mas nem sempre articulado pela sociedade como um todo.

Alan Merriam, expoente na tentativa de distinguir usos e funções da música na sociedade, dando-lhe suporte ou desestabilizando-a, afirma:

Quando falamos dos usos da música, estamos no referindo às maneiras pelas quais a música é utilizada na sociedade humana, como prática habitual (...) ou em conjunção com outras atividades. A Música tem uso em certas atividades, e se torna parte delas, mas pode ou não ter uma função profunda (1964:210 - grifo nosso).

Entre as funções da música apontadas por Merriam, incluem-se expressão emocional, prazer estético, entretenimento, comunicação, representação simbólica, respostas físicas, conformidade às normas sociais, validação de instituições sociais e contribuição à continuidade e estabilidade da cultura (1964:221-225). Bruno Nettl, 17 anos depois de 
Merriam, retoma a questão dos valores, afirmando que em cada cultura, a música terá como função expressar uma série de valores particulares de uma forma particular (1983:159).

Mesmo numa outra vertente, Weber afirma que a comunidade se autodefine e estabelece as suas fronteiras, bem como estabelece meios de diferenciação tanto interna como externa. Os costumes vivenciados e criados por uma comunidade especificam e são capazes de gerar e garantir a sua sobrevivência e reprodução. Weber a denomina "comunidade política", ou seja, está voltada para a ação, partilhando valores, costumes, uma memória comum, criando uma "comunidade de sentido", independentemente de laços sanguíneos, na qual há um "sentimento de pertencimento", porém a nucleação do programa no Conservatório parece desarticular esse sentido, gerando em determinados momentos anomalias nessa comunidade educativa e, muitas vezes, uma sobreposição de valores. Tais anomalias dificultam, aliada talvez à inconsciência do valores presentes, a definição de um modelo que supere o atual, a despeito de sua eficiência e dos resultados alcançados até agora.

Talvez as críticas de Franz Boaz (1896) à visão evolucionista da antropologia, que veiculava a idéia de "música primitiva" referindo-se à música indígena, por exemplo, pudesse iluminar a questão da idéia comum do "assédio pedagógico" a um suposto portador de talento ou "dom divino", que acaba por determinar uma hierarquia em que um aprendiz é mais importante do que outro por ser "muito mais evoluído" ou, digamos, propenso a uma evolução. Essa concepção reflete os valores sócio-econômicos do poder público e suas políticas culturais, e é ainda freqüentemente valorizada pela opinião pública por meio da mídia jornalística. Mas, também é bom que se diga, não é exclusiva do CDMCC, ao contrário, ainda circula e sobrevive em vários nichos pedagógicos em que a música reflete e reforça valores sociais preocupantes.

\section{O Conservatório de Tatuí na Modernização Reflexiva}

A modernização reflexiva, conforme definiu Ulrich Beck, significa "a possibilidade de uma (auto) destruição criativa para toda uma era (...). O sujeito dessa destruição criativa não é a crise, mas a vitória da modernização ocidental."

As transformações organizacionais ou reflexivas somente ocorrem quando o ser humano chega a momentos mais extremos. Isso significa que, enquanto o indivíduo estiver 
conformado com a situação existente não ocorrem mudanças significativas, ou seja, rupturas de paradigmas abrindo caminhos para outra modernidade.

\begin{abstract}
"Assim, em virtude do seu inerente dinamismo, a sociedade moderna está acabando com suas formações de classe, camadas sociais, ocupação, papéis do sexo, família nuclear, agricultura, setores empresariais e, é claro, também com os pré-requisitos e as formas contínuas do progresso técnicoeconômico. Este novo estágio, em que o progresso pode se transformar em autodestruição, em que um tipo de modernização destrói outro e o modifica, é o que eu chamo de etapa da modernização reflexiva”. (BECK, 1995, p. $16)$.
\end{abstract}

O setor cultural se revela um domínio a constituir recursos econômicos fundamentais, com capacidade para se afirmar como fonte de identidade, fator de desenvolvimento e de ações inovadoras dos indivíduos. “(...) a reflexividade torna-se uma empresa muito mais crítica com crescentes possibilidades para a autotransformação de pessoas e sistemas na modernidade.” (MENDES, C., org., 2001, p. 309). Sob um aspecto realista, mas preciso, o movimento que se presencia é a retomada organizacional da atividade cultural. As organizações tidas como modernas, hoje, participam do contexto da sociedade, da sua dinâmica, e procuram um elo de identificação na comunidade e não no poder público.

O Conservatório Dramático e Musical "Dr. Carlos de Campos” de Tatuí pode ser considerado um caso específico de organização, sendo que as razões que explicam essa especificidade são norteadoras devido a desejos políticos de pessoas que buscam a ascensão supostamente cultural da cidade. A cidade, por sua vez, que se autodenomina como "cultural", todavia sequer se faz presente nos eventos promovidos pela instituição.

O CDMCC de Tatuí sempre viveu sob a tensão da mudança de Secretário da Cultura. Para cada novo secretário, o CDMCC precisa "provar" seu potencial e "defender" a indústria cultural que representa, porque, geralmente cada novo secretário desconhece a existência do CDMCC de Tatuí.

Hoje, existe o consenso de que, na sociedade pós-industrial, cuja economia assume tendências globais, a cultura passou a ser considerada um precioso capital. A cultura como um valor em si. Os recursos que o Estado dedica à cultura musical têm que ser entendidos menos como investimento (que supõe um retorno econômico) e mais como um apoio à cultura da sociedade e ao conhecimento humano. A finalidade da cultura não é o mercado, mas a formação plena da identidade das pessoas e o enriquecimento imaterial dos grupos sociais.

Sendo assim, o CDMCC, alvo de valores diversos, existe e se mantém pela política vigente, todavia devemos lembrar que o governo não tem uma política cultural para Estado e 
muito menos para o CDMCC, que até os dias atuais prefere se isentar da supervisão do MEC e permanecer com suas diretrizes norteadoras de décadas passadas.

A cultura deve assumir um novo significado como um fator estruturante e como motivadora da gestão efetiva de organizações de ensino, as quais requerem percepção objetiva e precisa dos valores da música e de seu sistema organizacional em uma determinada concepção social.

O caráter formador das identidades culturais é constituído por um conjunto de códigos e práticas advindos de pessoas com a intenção de encontrar, transmitir e construir expressões autênticas de valor. A essência do trabalho musical consiste na busca contínua do desafio da qualidade sonora e do coletivo, e sua complexidade oferece inúmeras oportunidades de análises sócio-organizacionais, como a que tentamos desenvolver aqui.

A música gera motivação e um prazer lúdico e estético em sua realização, elementos essenciais que podem consolidar o ideal utópico de cooperação entre os instrumentistas e suas relações sociais. Nesse sentido a música poderia ser essencialmente libertária porque cria caminhos que atravessam tempos, lugares e grupos sociais. A utopia, no entanto, não se cumpre, pois há outros determinantes em jogo.

Diante do exposto entendemos que a desestruturação da produção cultural e pedagógica do CDMCC se mantém por insistência da política e por uma inconsciência coletiva dos valores que perpassam a instituição e suas práticas, que o sentido de pertencimento não consegue superar. Desde a sua instalação até os dias de hoje, o Conservatório de Tatuí passou por várias transformações, ocorridas na educação, na música, na economia, na política e na sociedade brasileira, porém quase nunca se cogitaram mudanças de cunho reflexivo na instituição e no sentido dos valores que ali se materializam. 


\section{CONCLUSÃO}

A realização deste trabalho nos colocou diante da situação da memória local e em contexto regional, mas banhada em questões de âmbito nacional. Ao longo do processo dessa dissertação, se algumas informações expostas nos capítulos ficaram sem respaldo documental, acreditamos termos trazido dados historiográficos suficientes para validar os pressupostos teóricos estabelecidos para nossa análise. A ênfase dada a estudos que analisam instituições de ensino do exterior, na qual se dá preferência a outras culturas em detrimento de uma história local ou regional, é que nos levou a determinar nosso objeto de estudo. Foi pensando nessa lacuna, que nos propusemos a pesquisar um pouco desse processo da história do ensino da música no CDMCC de Tatuí.

Com o propósito de apurar com rigor o sentido que tomou a produção histórica do CDMCC de Tatuí, com algumas análises amparadas em base empírica, iconografia, historiografia e referência teóricas, ressaltamos o sentido de pertencimento da instituição para com aqueles que estudaram nela e as contradições desse pertencimento com os valores musicais e educacionais e com o meio político, econômico e cultural.

Buscando superar o entendimento de historiografia como mera catalogação de fatos, documentos e obras, ou como análise temática ou cronológica, procuramos levar em conta não só a análise da produção do conhecimento histórico e o resgate da memória local, mas também compreender as condições de produção, reprodução, transformação e crítica. $O$ conhecimento histórico não se restringe apenas a marcos já consagrados e fatos históricos; assim, as histórias regionais podem ser o reflexo da expressão de períodos e grupos sociais de uma época, constituídos pelas experiências de sujeitos históricos.

Tatuí, conhecida como "Capital da Música", onde se acredita que sua população esteja inserida no contexto educacional da música devido ao Conservatório Dramático e Musical "Dr. Carlos de Campos" de Tatuí e à importância que assumiu no cenário nacional, abrigou durante longo período a única escola de música a ser mantida pelo governo do Estado. Sendo assim, o CDMCC vem sendo mantido pela política estadual, que quer mostrar que tem uma política cultural definida para o Estado, porém sem definir até hoje a validade do diploma expedido pela instituição.

Esperamos que a opção pela abordagem crítica do fenômeno histórico tenha 
habilitado esta investigação a mostrar ao leitor um quadro que deixa entrever conexões entre instituição educacional e políticas culturais, entre música e valores sócio-econômicos, artísticos e educacionais, entre os indivíduos e a cultura.

Longe de considerarmos essa conclusão como um fechamento sistemático de opiniões, entendemos que o produto deste trabalho também é um ponto de partida para que outras pesquisas do gênero possam ser realizadas e uma contribuição para futuros pesquisadores que venham a dar continuidade a esse entendimento de nossas instituições de ensino em contextos específicos.

Para Theodor W. Adorno, "as formas musicais reproduzem internamente as estruturas sociais" (1999, p. 65), como se fosse o primeiro compasso de uma melodia, à qual outros agregarão novas notas e novas interpretações. 


\section{REFERENCIAS BIBLIOGRÁFICAS}

ACQUARONE, F. História da Música Brasileira: Ed. Paulo de Azevedo Ltda, 1946.

ADORNO, T. W. O Fetichismo na Música e a Regressão da Audição: Os Pensadores. Ed. Abril, 1999.

ALMEIDA, Renato. História da Música Brasileira: Ed. F. Briguiet, 1942.

BENJAMIN, W. Magia e Técnica, Arte e Política: São Paulo, Ed Brasiliense 1985.

BOAS, Franz. "The Limitations of the Comparative Method", Science, vol. 04, 1896.

BOSI, E. Memória e Sociedade: Lembrança de Velhos: São Paulo Ed. Cia das Letras, 1998.

BOURDIEU, P. La Construcion Del Objeto in: El Oficio de Sociólogo: Ed. Siglo Veinteuno, 1978.

. Gosto de Classe e Estilos de Vida: (Grandes Cientistas Sociais, 39). São Paulo, Ed. Ática, 1983.

. A Economia das Trocas Simbólicas: São Paulo, Ed. Perspectiva. 1992.

BOURDIEU, P., Passeron, J. C. A Reprodução: Ed. Francisco Alves, 1982.

CAMARGO, Renato Ferreira de. Memórias de Tatuí: São Paulo Ed. João Scortecci, 1997.

CANCLINI, N.G., Culturas Híbridas: São Paulo, Ed. da USP, 1998.

CANDIDO, A, Os Parceiros do Rio Bonito: São Paulo, Ed. José Olimpio, 1964.

COELHO, Teixeira. O que é Indústria Cultural. (Primeiros passos, 08). São Paulo, Brasiliense, 1983.

CUCHE, Denys. A Noção de Cultura nas Ciências Sociais: Ed. EDUSC, 1999.

DE MASSI, D. A emoção e a regra, grupos criativos na Europa de 1850 a 1950: Ed. UnB, 1999.

DONATO, H. Achagas para a História de Botucatu, São Paulo, Ed. Edicon, 1985

ECO, U. Como se faz uma Tese: Ed. Perspectiva, 1999.

ELIOT, T. S. Notas para uma Definição de Cultura: Ed. Perspectiva, 2000.

FEIJÓ, Martins Cézar. O que é Política Cultural. (Primeiros passos, 107). São Paulo, Brasiliense, 1992.

FRANCO, F. de Assis C. História das Minas de São Paulo: Conselho Estadual de Cultura, São Paulo, 1964.

GIDDES, Anthony, BECK, U., LASH, S. Modernização Reflexiva: Ed. UNESP, 1997.

HORKHEIMER, Max/ ADORNO, Theodor W. Dialética do Esclarecimento. Rio de Janeiro.Ed.Zahar. 1985. 
KAPLAN, D., Manners, R. A. Teoria da Cultura. Rio de Janeiro, Ed. Zahar, 1975.

KATER Carlos, Música Viva e J.H.Koellreutter, movimentos em direção à modernidade. São Paulo, Ed.Musa, 2001.

KOSSOY, B., O Olhar Europeu: O Negro na Iconografia Brasileira do Século XIX. SP. Ed. EDUSP, 1994.

LIMA, Sonia Regina Albano de Escola Municipal de Musica-Criação e Desenvolvimento. São Paulo, Tese de Doutorado, PUC-SP.

LOPES, Antonia O., et al.. Repensando a Didática. Campinas, SP, Ed. Papirus, 1990.

MARIZ, Vasco. História da Música no Brasil: Ed. Civilização Brasileira, 1983. São Paulo.

MARTINS, Carlos Benedito. O que é Sociologia: (Primeiros passos, 57). São Paulo, Brasiliense, 1993.

MERRIAM, Alan P. The Anthropology of Music. Evanston: Northwestern University Press, 1964.

MENDES, Candido. (org.). Pluralismo Cultural, Identidade e Globalização Rio de Janeiro, Ed. Record, 2001.

MINHOTO, Laurindo Dias, Tatuhy Através da Historia pág. 138, S/d. e S/ed.

MORAES, J. Jota de. O que é Música. (Primeiros passos, 80). São Paulo, Brasiliense, 1983.

MOTA, Carlos G. Ideologia da Cultura Brasileira 1933/ 1974: Ed. Ática, 1994.

PINTO, A.V. Ciência e Existência. Rio de Janeiro, Ed. Paz e Terra, 1969.

PINTO, Louis, Pierre Bourdieu e a teoria do mundo social. Rio de Janeiro, Ed. FGV, 2000

PUTERMAN, P., Indústria Cultural: A Agonia de um Conceito: Ed. Perspectiva, 1994.

RAYNOR, Henry. História Social da Música. Rio de Janeiro, Ed. Guanabara,1986.

SALAZAR, Dr. José Monteiro. O Esconderijo do Sol: Ministério da Agricultura, 1988.

SCHEIN, Edgard H., Cultura Organizacional e Liderança. São Paulo, Ed. Atlas, 2009.

STRECK, Danilo R. Correntes Pedagógicas. Uma abordagem interdisciplinar. Petrópolis, RJ. Ed. Vozes, 2005.

SVEIBY, K. E., A Nova Riqueza das Organizações. Ed. Campus, 1998.

TOMAZI, N.D., Iniciação à Sociologia: São Paulo, SP, Ed. Atual, 1999.

TRIVIÑOS, A.N.S., Introdução à Pesquisa em Ciências Sociais. São Paulo, Ed. Atlas, 1987.

WARNIER, J. P., A Mundialização da Cultura: Ed. EDUSC, 2000.

WEBER, M. Os Fundamentos Racionais e Sociológicos da Música. São Paulo.

Ed. EDUSP. 1995.

A Ética Protestante e o Espírito do Capitalismo. São Paulo, Cia das Letras, 2004. 


\section{PESQUISA PELA INTERNET}

ABIFA - Associação Brasileira de Fundição. Disponível na INTERNET via www.abifa.org.br/revista.htm. Arquivo consultado em 2007.

EDUCAR-Disponível na INTERNET via www.educatur.hpg.ig.com.br/ipanema.htm. Arquivo consultado em 2001.

FERRO E MEMÓRIA. Disponível na INTERNET via http://www.icarobrasil.com.br/anteriores/edanterior/188/188ferro.htm. Arquivo consultado em 2001.

IPEMA - Instituto de Pesquisas e Estudos Morro de Araçoiaba. Disponível na INTERNET via www.geocities.com/ipema_. Arquivo consultado em 2007. IPHAN - Instituto do Patrimônio Histórico da Área Nacional. Disponível na INTERNET via www.iphan.gov.br/bancodados. Arquivo consultado em 2008.

\section{ARTIGOS}

ALMANACH TATUHYENSE, Histórico, Literário, Commercial e Recreativo Para o anno de 1900, organizado por Affonso Guimarães Porto, anno I 1900 - Tatuhy - São Paulo - Brasil: Restaurado por Renato Ferreira de Almeida, São Paulo,1997.

PROGRAMA DE EVENTOS do Conservatório Dramático e Musical "Dr. Carlos de Campos" de Tatuí. Realização Secretaria de Estado da Cultura e Governo do Estado de São Paulo.

REVISTA, edição comemorativa 50 anos sem Paulo Setúbal,1987. Tatuí.

REVISTA BRASILEIRA DE HISTÓRIA, Brasil 1954-1964: São Paulo, Ed.

Marco Zero - ANPUH, vol. 14, nº 27, 1994.

\section{JORNAIS}

Jornal, Correio Paulistano, 28 de abril de 1927. 


\section{ANEXO A - Transcrição: Ata da 16ª Reunião Ordinária de 21/03/1964.}

Ruy Botti Cartoleno, afirmando que em sua opinião, dadas as qualidades profissionais dos mestres a serem contratados achava de muita prestiça que viessem a perceber discernimento condignos com sua indescritível capacidade profissional. Com a palavra o senhor diretor informou que de acôrdo com a ordem do dia da presente reunião iria ser procedida a eleição do C.T.A. Para o biênio 64/65 e, na sua interpretação dos artigos 66,67 item 1, do regulamento o diretor, como membro da congregação também teria direito de voto, podendo, entretanto, qualquer professor apresentar impugnação, o que foi feito pelo prof. Alvis Elleuchoich. Continuando com a palavra o prof. Alvis Elleuchoich informava que trouxera uma procuração da prof ${ }^{a}$ Maria Antonieta Almeida Borges Favier, autorizando-o a votar e a eleição em apreço. O senhor diretor informou que em virtude em ser a eleição em forma de escrutínio secreto não poderia em seu parecer ser aceita tal procuração não obstante, iria submeter o assunto à apreciação da Congregação posto a votar que professores negaram a procuração e 5 aceitaram-na. O professor Ari de Jacomo Bisiglia impugnou a votação alegando que a mesma deveria ter sido em forma de escrutínio secreto e não descoberto como o foi. Em seguida procedeu-se a eleição do C.T.A., por escrutínio secreto, verificando-se o seguinte resultado: Ari de Jacomo Bisiglia - 5 votos; Benedita de Arruda Longhi - 7 votos; Luiz Gonzaga Barbosa - 7 votos; Maria Aparecida Holtz - 7 votos; Ruy Botti Cartoleno - 6 votos, Spartaro Rossi - 6 votos; Iolanda Rigonelli - 8 votos. Funcionaram como escrutinadores convidados pelo sub diretor os professores: Spartaro Rossi e Iolanda Rigonelli. Assim, foram eleitos os professores: Benedita de Arruda Longhi; Luiz Gonzaga Barbosa; Maria Aparecida Holtz e Iolanda Rigonelli, para constituir o C.T.A. no biênio 64/65, sendo pelo sub diretor devidamente empossado recebendo por proposta do professor Ruy Botti Cartoleno um voto de confiança e aplauso traduzido em uma salma de palmas. A seguir o Sr. Diretor desconversa sobre o processo da instalação dos cursos de professorado e virtuosidade na capital. Em seu entender a medida no momento, impossível de ser concretizada, por ser manifestamente ilegal, tendo em vista as leis $n^{\circ} 997$ que o conservatório e a diretrizes e bases. A esse respeito falou o professor Spartaco Rossi afirmando que a capital por circunstâncias óbvias seria o ambiente ideal para o aluno presidir um curso de aperfeiçoamento. Endossando as palavras do professor Ruy Botti Cartoleno, dizendo mais, que concluindo o aspecto financeiro o benefício para todo e qualquer aluno do interior, seria total, voltando a fazer uso da palavra o Sr. Diretor afirmou que o assunto era bastante delicado 
e que a respeito, soube através do Dr. Ubirajara Dolirio Mendes, consultor da secretaria do Governo, que teria um plano para a transferência do estabelecimento em etapas, onde a primeira seria a instalação dos referidos cursos na capital. Continuando em uma cartadocumento integrante do processo em apreço - do sub. Cesar Dias Batista, secretário particular do senhor governador onde se refere a instalação dos cursos em referência como solicitação da diretoria do conservatório com o que ele, como diretor atual, não poderia sociedade. R. Concluindo informou que pelos motivos que expôs, não poderia de forma alguma, pelo menos presentemente, com o projeto de instalação dos cursos de virtuosidade e professorado em São Paulo. Posta a palavra de que fez uso dela o professor Ari de Jacomo Bisiglia, afirmando ser estavelmente favorável a instalação dos cursos no tocante ao benefício técnico que iria trazer aos alunos, mas antes disso propunha que se criasse uma legislação inerente. A fim de que ser decidido um aspecto legal ao assunto. Esta proposta recebeu aprovação unânime da Congregação. Pelo professor Ruy Botti Cartoleno, foi questionada a questão relativa ao horário dos senhores professores. Declaramos suscitamente sobre o regulamento da escola, na parte referente ao assunto, afirmando que no ensino secundário a interpretação é dada como "Hora-aula", isto é 50 minutos e não 60. Relativamente ao descanso de 10 minutos refeições que o mesmo teria que ser a critério do professor mesmo porque no ensino secundário esse período é visando o descanso do aluno, o que não se protificaria em nossa escola, onde as aulas são de caráter individual. Ficou resolvido que o assunto seria cedido a consideração do C.T.A. A fazer uso da palavra o sub diretor levou consideração de congregação o problema dos alunos da disciplinas história de música e noções de ciências físicas e biológicas aplicadas à música que não prestavam o exame final no último ano letivo, em virtude de não haver sido concluido os respectivos programas face a folia de profesores. Informou que durante a recencia de congregação e C.T.A., havia resolvido que a prof ${ }^{a}$ Iolanda Rigonelli ministraria as aulas dessas disciplinas e que na primeira reunião do C.T.A; Esse órgão resolveria definitivamente o assunto. Com a palavra o prof. Ary de Jacomo Bisiglia, solicitou do sub diretor a alteração de seu horario, para as quintas-feiras e sabados. O assunto ficou de ser resolvido pelo C.T.A. Nada mais, havendo o sub diretor encerrou os trabalhos. Eu, Helio Reali, secretário o lavrei e subscrevi. 
ANEXO B - Transcrição: Ata da 24ª Reunião Ordinária de 24/04/1969.

Ata da $24^{a}$ Reunião Ordinária da Congregação do Conservatório Dramático e Musical “ Dr. Carlos de Campos" de Tatuí, com início as 15 horas: Data 24 de Abril de 1969. Local: Rua São Bento, 415 em Tatuí.

Com a presença dos senhores Professores, Ana Maria Teixeira de Almeida, Benedicta de Arruda Longhi, Dirce Bertrame Teixeira, Eny Vanni, Eunice Schinerder Madeira Gagliardi, Hebe Hermeto Villaça, Hélia Jordão Suardi, Luiz Gonzaga Barbosa, Maria Aparecida Holtz, Maria Aparecida Serafim Oliveira, Marialice Rodrigues Ferreira, Marina Thereza Filardi Peixoto, Nilson Lombardi, Odete Toledo Vieira, Paulino Pellegrini, Rui Botti Cartolano, Spartaro Rossi e Yolanda Rigonelli, o Sr. Diretor e Presidente abriu os trabalhos. Foi lida e aprovada a Ata da Reunião anterior. Com a palavra o Sr. Diretor Informou que a presente Reunião deveria ser levada a efeito em março, mas tendo em vista a mudança da escola para o novo prédio que hoje orgulhosamente se inaugura, não foi possível efetuá-la razão pela qual somente nesta data esta reunindo a Congregação. Continuando com a palavra abordou os seguintes assuntos: 1- Importância dos alunos residentes fora da cidade, pois são eles que tornarão a escola regional, velha aspiração de Tatuí. 2- Relatorio dos anos 1.968 e 1.969. Por unanimidade a Congregação não só aprovou o relatório apresentado, como também cumprimentou o Sr. Diretor pela dedicação e discernimento com que vem dirigindo o estabelecimento. 3- Respostas dos alunos e senhores pais, relativas ao questionário elaborado pela Direção da Escola. Ficou determinado as respostas serão analizadas pela Congregação em sua próxima reunião. Por sugestão da Prof ${ }^{a}$ Yolanda Rigonelli, foi aprovada a elaboração por parte do Sr. Diretor da Escola de um questionário dirigido aos senhores Professores. Sobre esse assunto informou o Sr. Diretor que tal questionário já estava elaborado, ficando de entrega-los aos senhores Professores oportunamente; 4- Indicação do Prof. Paulino Pellegrini para estrurar o Conselho Pedagógico, e do Prof. Rui Botti Cartolano, para organizar os testes de musicalidades. Continuando com a palavra o Sr. Diretor informou que na semana da Musica deste ano serão realizados o $5^{\circ}$ Concurso de Piano e o $2^{\circ}$ de Coral. Não obstante referida semana realizada somente em novembro, a direção da Escola Louvera decidido designar uma Comissão de Professores para com antecedencia , organizar toda a programação relativa aquelas festividades. A Comissão é a seguinte: Benedicta de Arruda Longhi, Dirce Bertrame Teixeira, Maria Aparecida Serafim Oliveira, Nilson Lombardi, Spartaro Rossi e Yolanda Rigonelli: Antes de concluir a reunião o Sr. Diretor orgulhosamente comunicou a 
Congregação o Decreto n51.717 de 21.04.69, que autoriza a Direção da Escola nos moldes da C.L.T., a contratar professores para a disciplina que for necessária. Congratulou-se com o Sr. Diretor o prof. Rui Botti Cartolano, afirmando que tal Decreto abriria novos horizontes para a Escola. Como convidada esteve presente a Prof ${ }^{a}$ Ercilia Castilho Cardoso, Diretora do Conservatório de Canto Orfeonico do Estado, a qual fazendo uso da palavra parabenizou-se com o Sr Diretor, por tudo que tem feito em favor da musica. Encerrando a reunião o Sr. Diretor, Prof José Coelho de Almeida, agradeceu a todos a cooperação recebida, propondo também que ficasse consignada na Ata dos trabalhos de hoje, um voto de louvor do $\mathrm{Sr}$. Orlando Gabriel Fancaner, Secretário da Cultura, Esporte e Turismo e um voto de agradecimento ao Prefeito Orlando Lisboa de Almeida, por tudo que tem feito em prol do Conservatório sendo as duas propostas aprovadas por unanimidade. Não mais havendo a registrar, o Sr. Diretor encerrou os trabalhos. Eu João Eurico de Melo Toledo, Responsável pela secretaria o lavrei e subscrevi. 


\title{
ANEXO C - Transcrição de Decreto
}

\author{
Sábado, 06 de março de 1971
}

\section{DECRETO N 52.687, DE 5 DE MARÇO DE 1971}

Dispõe sobre o novo Regulamento do Conservatório Dramático e Musical "Dr. Carlos de Campos", de Tatuí.

ROBERTO COSTA DE ABREU SODRÉ, GOVERNADOR DO ESTADO DE SÃO PAULO, usando de suas atribuições e nos termos do artigo 15 do Decreto-lei Complementar n.o. 7 de 6 de novembro de 1969, combinado com o artigo 89 da Lei Estadual n.o. 9.717, de 30 de janeiro de 1967, e com o Ato Institucional n. 8, de 2 de abril de 1969.

\section{Decreta:}

Artigo 1.o - O Conservatório Dramático e Musical "Dr. Carlos de Campos" de Tatuí, criado pela Lei Estadual n.o 997, de 13 de abril de 1951; passa a reger-se pelas disposições do Regulamento aprovado pelo presente decreto e a ele anexo.

Artigo 2.o - Este decreto entra em vigor na data de sua publicação, ficando revogados os Decretos n.os 25.436, de 3 de fevereiro de 1956, 34.606 de 27 de janeiro de 1959, 43.124, de 4 de março de 1964, e 49.220, de 17 de janeiro de 1968.

Palácio dos Bandeirantes, 5 de março de 1971

\section{ROBERTO COSTA DE ABREU SODRÉ}

Paulo Marcondes Pestana, Secretário de Cultura, Esportes e Turismo

Publicado na Casa Civil, aos 5 de março de 1971

Maria Angélica Galiazzi, Responsável pelo S.N.A. 


\section{REGULAMENTO DO CONSERVATÓRIO DRAMÁTICO E MUSICAL \\ “DR. CARLOS DE CAMPOS" DE TATUÍ}

CAPÍTULO I

\section{Da localização e fins}

Artigo 1.o - O Conservatório Dramático e Musical “Dr. Carlos de Campos”, de Tatuí, criado pela Lei n. 997, de 13 de abril de 1951, rege-se pelo presente Regulamento, elaborado "ex-vi" do parágrafo único do artigo 47 da Lei Federal n. 4.024, de 20 de dezembro de 1961 (Lei de Diretrizes e Bases da Educação Nacional), e destina-se a:

I - transmitir pelo ensino conhecimentos de Arte Musical e Arte Dramática aplicada à música;

II - formar técnicos e profissionais de música, desenvolvendo e aprimorando vocações artísticas;

III - promover e estimular a difusão da música, inclusive preservando o desenvolvimento da música brasileira.

CAPÍTULO II

\section{Da Organização Didática}

\section{SEÇÃO I \\ Do Ensino}

Artigo 2.o - O ensino será ministrado em dois graus: Fundamental e Geral.

$\S 1.0$ - O Grau Fundamental é preparatório do Geral.

$\S 2.0$ - O Grau Geral tem por finalidade formar instrumentistas, coristas, cantores, professores, e dará diploma aos alunos que concluirem os cursos.

\section{SEÇÃO II}

\section{Dos Cursos}

Artigo 3.o - Serão estabelecidos os seguintes Cursos, com a respectiva duração e número de professores estipulados:

I - Instrumentais:

a) Piano; em 8 anos; 6 no Grau Fundamental e 2 no Grau Geral - 5 professores;

b) Violino, igual ao de Piano - 1 professor:

c) Viola, igual ao de Violino - 1 professor; 
d) Violoncelo, igual ao de Viola - 1 professor;

e) Contrabaixo, em 6 anos; 4 no Grau Fundamental e 2 no Grau Geral - 1 professor

f) Harpa, igual ao de Piano - 1 professor;

g) Violão, igual ao de Harpa - 1 professor;

h) Flauta (Flautim), em 6 anos; 4 no Grau Fundamental e 2 no Grau Geral - 1 professor;

i) Oboé (Corno Inglês), igual ao de Flauta - 1 professor;

j) Clarineta (Clarineta Baixa) ou Saxofone, igual ao de Oboé - 1 professor;

l) Fagote (Contrafagote), igual ao de Clarineta - 1 professor;

m) Trompa, igual ao de Fagote - 1 professor;

n) Trompete, igual ao de Trompa - 1 professor;

o) Trombone ou Tuba, igual ao de Trompete - 1 professor;

p) Tímpanos Percussão e Acessórios igual ao de Trombone - 1 professor.

II - Canto, em 6 anos; 4 no Grau Fundamental e 2 no Grau Geral - 1 professor.

III - Bailado, igual ao de Canto - 1 professor.

IV - Facultativos:

a) Iniciação Musical, em 2 anos, para crianças de 6 a 9 anos - 1 professor;

b) Preparatório de 2 anos aos diversos Cursos, destinado a maiores de 9 anos - Professores dos Cursos Instrumentais e de Canto;

c) Aperfeiçoamento (pós-graduação), em 2 anos;

d) Composição e Regência em extensão curricular de mais 3 anos, com a devida complementação técnica.

Parágrafo único - Filiado ao Curso de Iniciação Musical, funcionará um Curso de Flauta Doce, em caráter de curso livre e sem limite de idade.

\section{SEÇÃO III}

\section{Das Disciplinas}

Artigo 4.o - Considera-se disciplina principal aquela que dá denominação ao próprio curso.

Artigo $5^{\mathbf{0}}$ - São disciplinas complementares dos diversos cursos, com a duração estabelecida, e o número de professores estipulados;

I - Teoria e Solfejo (Percepção Musical), em 3 anos - 1 professor;

II - Orfeão (Apreciação Musical), em 4 anos, 1 Professor;

III - Coral (Percepção Musical), em 4 e 2 anos, o mesmo professor de Orfeão;

IV - Estruturação Musical Elementar, em 2 anos - 1 Professor;

V - Análise Musical, em 2 anos - o mesmo professor de Estruturação Musical; 
VI - História da Música e Apreciação Musical em 2 anos - 1 Professor;

VII - Folclore Musical, em 1 ano - o mesmo professor de História da Música;

VIII - Prática de Orquestra, em 4 anos (para os cursos de 6 anos) e 5 anos (para os de 8 anos)- 1 Professor;

IX - Música de Câmera, em 2 anos - os professores dos respectivos cursos instrumentais e vocal;

X - Biologia Aplicada e Acústica, em 1 ano - 1 Professor;

XI - Psicologia Aplicada e Pedagogia, em 2 anos - 1 Professor;

XII - Dicção e Arte Dramática, em 1 ano - o mesmo professor de Canto;

XIII - Declamação Lírica, em 1 ano - o mesmo professor de Canto.

XIV - Canto e Dança, em 2 anos, o mesmo professor de Curso de Iniciação Musical;

XV - Ginástica rítmica, em 2 anos, o mesmo professor de Canto e Dança;

XVI - Noções de Teoria e Solfejo (Percepção Musical) em 2 anos, o mesmo professor de Ginástica rítmica;

XVII - Banda rítmica, em 2 anos, o mesmo professor de Noções de Teoria e Solfejo;

XVIII - Iniciação Instrumental, em 1 ano, o mesmo professor de Banda Rítmica;

XIX - Estruturação Musical Superior e Análise Musical, em 3 anos - 1 Professor;

XX - Instrumentação e Orquestração, em 2 anos - o mesmo professor de Estruturação Musical Superior e Análise Musical;

XXI - Regência, em 2 anos, o mesmo professor de Prática de Orquestra;

XXII - Piano Complementar: em 3 anos, para cursos instrumentais e de Composição e Regência: em 6 anos, para Curso de Canto, os mesmos professores de Piano.

$\S 1^{\circ}$ - As disciplinas e estruturação do Curso de Bailado serão estabelecidas pelo C.T.A.

$\S 2^{\circ}$ - O Conservatório ministrará aulas de Educação Moral e Cívica, nos têrmos da legislação vigente que regula a matéria, dispensados de frequência às mesmas os alunos que as recebem em outras escolas.

\section{SEÇÃO IV}

\section{Da seriação}

Artigo $6^{\circ}$ - Fica estabelecida a seguinte seriação para os Cursos de que trata o artigo $3^{\circ}$ :

I - Instrumentais (Piano - Violino - Viola - Violoncelo - Harpa e Violão).

a) no Grau Fundamental (juntamente com o instrumento):

$1^{\mathbf{a}}$ - $\mathbf{2}^{\mathbf{a}}$ e $3^{\mathrm{a}}$ séries - Teoria e Solfejo (Percepção Musical) - Orfeão (Apreciação Musical) 
$4^{\text {a }}$ série - Orfeão (Apreciação Musical) - Estruturação Musical Elementar - Prática de Orquestra.

$5^{\mathbf{a}}$ série - Coral (Percepção Musical) - Estruturação Musical Elementar - Análise Musical Prática de Orquestra - História da Música (Apreciação Musical).

$6^{\mathbf{a}}$ série - Coral, (Percepção Musical) - Análise Musical - Prática de Orquestra - História da Música - (Apreciação Musical) - Folclore Musical.

b) No Grau Geral (juntamente com o instrumento);

$7^{\text {a }}$ série - Coral (Percepção Musical) - Prática de Orquestra - Música de Câmera - Psicologia Aplicada e Pedagogia - Biologia Aplicada e Acústica;

$8^{\mathbf{a}}$ série - Coral (Percepção Musical) - Prática de Orquestra - Música de Câmera - Psicologia Aplicada e Pedagogia.

II - Instrumentais (Contrabaixo - Flauta - Oboé - Clarineta ou Saxofone - Fagote - Trompa - Trompete - Trombone ou Tuba - Tímpanos, percussão e acessórios).

a) No Grau Fundamental (juntamente com o instrumento):

$2^{\mathbf{a}}$ e $3^{\mathbf{a}}$ séries - Teoria e Solfejo ( Percepção Musical) - Orfeão (Apreciação Musical);

$3^{\mathbf{a}}$ série - Orfeão (Apreciação Musical) - Prática de Orquestra - Estruturação Musical Elementar;

$4^{\text {a }}$ série - Coral (Percepção Musical) - Prática de Orquestra - Estruturação Musical Elementar - História da Música e Apreciação Musical - Análise Musical; - Biologia e Acústica.

b) No Grau Geral (juntamente com o instrumento);

$5^{\mathbf{a}}$ série - Coral (Percepção Musical) - Prática de Orquestra - História da Música e Apreciação Musical - Análise Musical - Folclore Musical - Música de Câmera - Psicologia Aplicada e Pedagogia;

6 $^{\mathbf{a}}$ série - Coral (Percepção Musical) - Prática de Orquestra - Música de Câmera - Psicologia Aplicada e Pedagogia.

III - Canto

a)No Grau Fundamental (juntamente com a disciplina principal):

$2^{\mathbf{a}}$ e $3^{\mathbf{a}}$ séries - Teoria e Solfejo (Percepção Musical) - Orfeão (Apreciação Musical);

3.a série - Teoria e Solfejo (Percepção Musical) - Orfeão (Apreciação Musical) Estruturação Musical Elementar.

4.a série - Orfeão - (Apreciação Musical) - Estruturação Musical Elementar - Prática de Orquestra; Biologia Aplicada e Acústica

a)No Grau Geral (juntamente com a disciplina principal): 
5.a série - Coral (Percepção Musical) - Análise Musical - Prática de Orquestra - História da Música (Apreciação Musical) - Dicção e Arte Dramática; Psicologia Aplicada e Pedagogia.

6.a série - Coral (Percepção Musical) - Análise Musical - Prática de Orquestra - História da Música e Apreciação Musical - Folclore Musical - Declamação Lírica, Psicologia Aplicada e Pedagogia.

IV - Curso de Iniciação Musical

1.a série - Canto e Dança - Ginástica Rítmica - Noções de Teoria e Solfejo - (Percepção Musical) - Banda Rítmica;

2.a série - As mesmas disciplinas da 1.a série, mais Iniciação Instrumental.

V - Curso Preparatório

1)Juntamente com um instrumento ou Canto, nas séries A e B: Teoria e Solfejo (Percepção Musical) e Apreciação Musical.

VI - Curso de Aperfeiçoamento (pós - graduação).

1)Juntamente com um instrumento ou Canto, nas 1.a e 2.a séries; Prática de Orquestra e Música de Câmera.

VII - Curso de Composição e Regência

1.a série - Estruturação Musical Superior - Análise Musical - História da Música e Folclore - Regência;

2.a série - Estruturação Musical Superior - Análise Musical - História da Música e Folclore - Regência - Instrumentação e Orquestração;

3.a série - Estruturação Musical Superior - Análise Musical - Regência - Instrumentação e Orquestração.

Parágrafo único - A disciplina Piano Complementar será ministrada:

1 - Nas 3.a, 4.a e 5.a séries dos Cursos de Violino, Viola e Violoncelo;

2 - Nas 2.a, 3.a e 4.a séries dos Cursos de Contrabaixo, Flauta, Oboé, Clarineta ou Saxofone, Fagote, Trompa, Trompete, Trombone e Tuba;

3 - Em toda a seriação dos Cursos de Canto e Composição e Regência.

\section{SEÇÃO V}

\section{Do número de aulas e sua duração}

Artigo $\mathbf{7}^{\mathbf{0}}$ - Serão ministradas nos cursos instrumentais duas aulas semanais de disciplina principal sendo uma individual e outra coletiva, com a duração de 50 minutos cada uma. $\S 1^{\circ}$ - A aula individual poderá ser assistida por 2 ou 3 alunos, convocados pelo Diretor. 
$\S 2^{\circ}$ - A aula coletiva será ministrada a todos os alunos de uma mesma série e uma só classe, podendo ser assistida por alunos de outras séries e classes, quando convocados pelo Diretor.

$\S 3^{\circ}$ - Uma vez cada dois meses, em dia e hora previamente marcados, haverá uma aula coletiva da disciplina principal, para todos os alunos dos vários professores de uma mesma série.

Artigo $8^{\mathbf{0}}$ - No Curso de Canto serão ministradas 3 aulas semanais da disciplina principal, de 30 minutos cada uma, sendo 2 individuais e uma coletiva.

$\S 1^{\circ}$ - A aula individual será assistida por 2 ou 3 alunos, convocados pelo Diretor.

$\S 2^{\circ}$ - A aula coletiva será ministrada aos alunos de uma ou mais séries, convocados pelo Diretor.

Artigo $9^{\circ}$ - No Curso de Iniciação Musical, as aulas de Canto e Dança, Ginástica Rítmica, Noções de Teoria e Solfejo e Banda Rítmica serão ministradas uma vez por semana e a de Iniciação Instrumental, duas vezes por semana.

Parágrafo único - As aulas de Iniciação Instrumental, com a duração de 30 minutos cada uma, serão ministradas a grupos de 3 a 5 alunos. As das demais disciplinas serão ministradas simultâneamente, com a duração de 50 minutos cada aula.

Artigo 10 - No Curso Preparatório, as aulas de instrumento serão ministradas duas vezes por semana, a grupos de 3 a 5 alunos, com a duração de 50 minutos cada uma.

Parágrafo único - As aulas de Teoria e Solfejo e Apreciação Musical serão coletivas e ministradas uma vez por semana, com a duração de 50 minutos.

Artigo 11 - No Curso Preparatório de Canto, as aulas da disciplina principal serão ministradas três vezes por semana, a grupos de 3 a 5 alunos, com a duração de 30 minutos cada uma.

Parágrafo único - As aulas de Teoria e Solfejo e Apreciação Musical serão coletivas e ministradas uma vez por semana, com a duração de 50 minutos.

Artigo 12 - No curso de Aperfeiçoamento (pós-graduação), as aulas de instrumento ou de Canto serão individuais e ministradas quinzenalmente, com a duração de 50 a 90 minutos podendo ser assistidas por grupos de alunos, convocados pelo Diretor.

Parágrafo único - As aulas de Prática de Orquestra e Música de Câmera serão coletivas e ministradas quinzenalmente, com a duração de 50 a 90 minutos cada uma.

Artigo 13 - No Curso de Composição e Regência serão ministradas, para cada uma das disciplinas integrantes das três séries, duas aulas coletivas por semana, com a duração de 50 minutos cada uma. 


\section{SEÇÃO VI}

\section{Dos Programas}

Artigo 14 - Os programas das disciplinas integrantes dos vários cursos serão simples, claros, flexíveis e obedecerão normas gerais e uniformes.

$\S 1^{\circ}$ - Os programas serão elaborados pelos respectivos professores e submetidos à apreciação do CTA.

$\S 2^{\circ}$ - Os programas dos vários cursos poderão ser alterados:

1 - por proposta de professor, aprovada pelo C.T.A.;

2 - por proposta de Diretor, aprovada pelo C.T.A.;

3 - pelo C.T.A.

$\S 3^{\circ}$ - Os programas e alterações previstas no parágrafo anterior deverão ser homologados pela Congregação.

Artigo 15 - A matéria constante de um programa não poderá ser repetida em outro de disciplina diversa, competindo ao S.T.A. determinar à qual delas pertence, caso discordem os professores.

\section{CAPÍTULO II}

Do corpo docente

SEÇÃO I

\section{Da sua constituição}

Artigo 16 - O corpo docente será constituído por professores efetivos, professores admitidos ou contratados.

$\S 1^{\circ}$ - O provimento do cargo de professor em caráter efetivo será feito mediante concurso de títulos e provas.

$\S 2^{\circ}$ - A admissão de professores será para a regência de aulas excedentes, observadas as normas legais vigentes.

$\S 3^{\circ}$ - O contato de professores recairá em especialistas de reconhecida capacidade profissional e notória projeção, para a regência de aulas e cursos, ou execução de trabalhos especializados, inclusive pesquisas científicas, técnicas ou artísticas de interesse do ensino.

\section{SEÇÃO II}

\section{Das aulas}

Artigo 17 - As aulas ministradas pelo professor efetivo serão consideradas ordinárias até o limite de 18 semanais e de 80 mensais, inclusive. 
$\S 1^{\circ}$ - As aulas que ultrapassarem os limites fixados neste artigo serão consideradas excedentes e seu valor, para efeito de remuneração, será igual a 1/80 (um oitenta avos) do valor da referência.

$\S 2^{\circ}$ - Para efeito de cálculo para pagamento de aulas excedentes, o mês será considerado com 4,5 semanas.

$\S 3^{\circ}$ - Não poderá o professor ultrapassar o limite de 36 horas semanais de trabalho.

$\S 4^{\circ}$ - Quando o professor ministrar aulas em diversos estabelecimentos, deverá fornecer ao Conservatório declaração do horário de aulas e de atividadades extra-classe remuneradas a que está obrigado.

Artigo 18 - Além da disciplina de que é titular, poderá o professor lecionar outras disciplinas para as quais esteja habilitado, mediante aprovação do C.T.A.

Parágrafo único - Na hipótese do número de aulas da disciplina não atingir o limite das obrigatórias previsto no artigo 17 , o docente é obrigado a prestar no estabelecimento, serviços relacionados com a disciplina ou regência de aulas de disciplinas, até completar o tempo correspondente àquele número.

\section{SEÇÃO III}

\section{Dos deveres e proibições}

Artigo 19 - São inerentes à função docente os trabalhos de exames e provas e o comparecimento a reuniões cursos, seminários, concertos, recitais, festividades cívicas e outros atos escolares promovidos pela Escola.

Parágrafo único - A Ausência aos atos previstos neste artigo acarretará desconto proporcional na remuneração, desde que não seja abonada nos têrmos do $\S 1^{\circ}$ do artigo 110 da Lei 10.261, de 28 de outubro de 1968.

Artigo 20 - Incumbe, ainda, ao professor:

I - Comparecer com pontualidade ao estabelecimento e reger as aulas dentro dos horários elaborados, considerando-se desídia, para os efeitos legais, o fato de, sem causa justificável devidamente comprovada deixar o professor de comparecer a, pelo menos, $75 \%$ das aulas e de desenvolver, no mínimo, 3/4 (três quartos) dos respectivos programas de ensino.

II - Ocupar-se, em classe, exclusivamente com o ensino de sua disciplina;

III - Elaborar e cumprir os programas da disciplina a seu cargo;

IV - Manter atualizados os conhecimentos relativos às disciplinas que ministrar e comparecer a seminários de estudo, certames culturais, encontros pedagógicos e outros, sempre que convocado pelo Diretor; 
V - Preparar alunos para audições, recitais, concursos ou certames que a Escola promover ou dos quais participar;

VI - Propor, por escrito, ao Diretor a aquisição de livros, discos, peças e métodos musicais destinados à Seção de Biblioteca;

VII - Manter com os colegas e demais funcionários o espírito de colaboração indispensável à eficiência da obra educativa que se processa na Escola;

VIII - Elaborar, nos prazos fixados pelo Diretor, os planos de curso e submetê-los à apreciação do C.T.A.;

IX - Entregar, até o quinto dia útil de cada mês, à Secretaria do estabelecimento, os registros de notas e faltas dos alunos e, dentro de 5 dias após a sua realização, as provas de exames convenientemente julgadas;

$\mathbf{X}$ - Apresentar, até o último dia útil de novembro, a relação dos seus alunos com os respectivos programas devidamente preenchidos ou relação da matéria relacionada em cada disciplina, se for o caso, para aprovação do C.T.A.;

XI - Observar, nas notas mensais e nas notas das provas as normas que forem baixadas, tendentes a assegurar a necessária unidade e objetividade no critério de julgamento;

XII - Permanecer na Escola uma vez por semana e pelo tempo fixado pela Direção, a fim de:

a) esclarecer dúvidas de seus alunos;

b)elaborar plano de trabalho para seus alunos;

c)analisar e relatar o aproveitamento escolar de seus alunos e

d)realizar pesquisas ou estudos, elaborando para tanto Plano de Trabalho que submeterá à aprovação do C.T.A.

Artigo 21 - É vedado ao professor:

I - ferir a suscetibilidade dos alunos, no que diz respeito às suas convicções religiosas e políticas, à sua nacionalidade e côr, à sua capacidade intelectual e condição social;

II - fazer proselitismo religioso ou político partidário, sob pretexto da liberdade de cátedra, bem como pregar doutrinas contrárias ao interesse nacional ou insuflar nos alunos, clara ou disfarçadamente, atitudes de indisciplina ou agitação;

III - falar em nome do estabelecimento, em qualquer oportunidade, sem que para isso esteja credenciado;

IV - aplicar penalidades nos alunos;

V - atribuir nota ou consignar falta ao aluno por motivo disciplinar, ou diminuir-lhe a nota pela mesma razão. 


\section{SEÇÃO IV}

\section{Das Disposições Gerais}

Artigo 22 - No caso de existir no estabelecimento mais de um professor para a mesma disciplina, deverão os respectivos titulares estabelecer critério comum para o ensino.

Parágrafo único - O ensino será dirigido de forma a evitar-se que no transcorrer do curso, mesmo tendo diversos professores, o aluno receba mais de uma orientação técnica.

Artigo 23 - A unidade de ensino nos diversos cursos será assegurada:

I - através de decisões tomadas em reuniões de professores;

II - mediante orientação de caráter técnico e pedagógico dada por especialistas de reconhecida capacidade profissional e notória projeção, para esse fim contratados.

\section{CAPÍTULO IV}

\section{Do corpo discente \\ SEÇÃO I}

\section{Da sua constituição}

Artigo 24 - Constituem o corpo discente os alunos regularmente matriculados.

\section{SEÇÃO II}

\section{Do Regime Disciplinar}

Artigo 25 - Ao aluno cabe zelar pelo bom nome do estabelecimento, procurando honrá-lo com sua conduta irrepreensível e com o cumprimento dos deveres escolares.

Artigo 26 - São deveres dos alunos:

I - comparecer pontualmente às aulas, provas, audições, concertos, recitais e outras atividades escolares promovidas pelo Conservatório;

II - Manter-se atento às aulas e desincumbir-se das tarefas que lhe forem atribuidas pelos professores, dedicando-se ao estudo e à execução dos deveres escolares;

III - justificar suas ausências e trazer consigo a caderneta escolar, apresentando-a sempre que lhe for exigida;

IV - acatar a autoridade do Diretor, dos professores e dos funcionários do estabelecimento, tratando-os com urbanidade e respeito;

$\mathbf{V}$ - tratar com civilidade os colegas;

VI - apresentar-se com asseio, decentemente trajado, ou usar uniforme, quando adotado; VII - ocupar, na sala, o lugar que lhe for designado, ficando responsável pela respectiva carteira; 
VIII - Possuir o material escolar exigido, conservando-o em ordem;

IX - colaborar com a direção do estabelecimento na conservação do prédio, do mobiliário escolar e de todo o material de uso coletivo, concorrendo, também, para que se mantenha rigoroso asseio no edifício e suas dependências;

$\mathbf{X}$ - observar, no recinto do estabelecimento, conduta compatível com a disciplina e a boa ordem do ensino;

XI - usar de probidade na execução das provas, sabatinas, exercícios e demais atos escolares;

XII - indenizar o prejuízo quando produzir danos materiais ao estabelecimento, ou em objetos de propriedade de colegas, de funcionários ou de professores;

XIII - ter adequado comportamento social, concorrendo, sempre, onde quer que se encontre, para elevação do conceito do estabelecimento;

XIV - devolver no devido tempo os livros, métodos e peças que retirar da Biblioteca, para estudo ou consulta.

Artigo 27 - É vedado aos alunos:

I - entrar em classe ou dela sair sem permissão do professor, e do estabelecimento, sem autorização do Diretor durante as aulas;

II - ocupar-se, durante a aula, de qualquer atividade que lhe seja alheia;

III - promover, sem autorização do Diretor, coletas e subscrições, dentro ou fora do estabelecimento;

IV - formar grupos ou promover algazarra e distúrbios nos corredores e pátios, bem como nas imediações do estabelecimento, durante o período das aulas, no seu início ou término;

V - impedir a entrada de colegas na escola ou às aulas, concitá-los a ausências coletivas ou delas participar;

VI - trazer para a escola material estranho às atividades escolares;

VII - assacar injúria ou calúnia entre colegas, professores ou funcionários do estabelecimento, ou praticar contra os mesmos ato de violência;

VIII - promover ou participar de movimentos hostilidade ou desprestígio à escola, a seus elementos e às autoridades constituídas;

IX - praticar ato ofensivo à moral e aos bons costumes;

$\mathbf{X}$ - divulgar, por qualquer meio de publicidade, assuntos que envolvam, direta ou veladamente o nome da escola, de professores ou funcionários, sem autorização do Diretor; XI - utilizar-se de livros, cadernos ou outros materiais de colegas, sem o consentimento destes;

XII - distrair a atenção dos colegas em aula, com objetos, ditos ou por qualquer outra forma; 
XIII - permanecer nos recreios e intervalos fora dos recintos que lhe forem destinados bem como transitar pelos corredores em hora de aula;

XIV - gravar nas paredes, no assoalho ou em qualquer parte do edifício ou material escolar palavras, desenhos ou qualquer sinal;

$\mathbf{X V}$ - fumar no recinto do estabelecimento.

Artigo 28 - Os alunos pela inobservância dos deveres e das proibições fixadas neste Regulamento estarão sujeitos às seguintes penalidades:

I - Admoestação verbal;

II - Repreensão escrita;

III - Suspensão até 6 dias;

IV - Exclusão do estabelecimento.

$\S 1^{\circ}$ - As penalidades previstas nos itens I, II e III serão aplicadas de plano pelo Diretor, segundo a gravidade da falta.

$\S 2^{\circ}$ - A penalidade prevista no inciso IV será aplicada pelo Diretor após apuração da falta em processo regular, observando-se as normas estabelecidas para o processo administrativo e ouvido o C.T.A.

$\S 3^{\circ}$ - O aluno suspenso não participará de qualquer ato escolar que se realizar no decurso da suspensão.

$\S 4^{\circ}$ - O Diretor comunicará aos pais ou responsáveis a aplicação de penalidades;

Artigo 29 - Em relação ás penalidades referidas nos itens III e IV do artigo 28, caberá pedido de reconsideração. Denegado este, poderá ser interposto recurso pelo aluno ou por seu responsável se menor, à Congregação, no prazo de 5 dias a contar do recebimento da notificação.

Parágrafo único - O pedido de reconsideração ou recurso não terá efeito suspensivo.

Artigo 30 - Será aplicada a penalidade prevista no ítem IV do artigo 28 ao aluno que cometer as seguintes faltas:

I - Reincidência sistemática às proibições do Regulamento e à inobservância dos deveres;

II - Prática de atos desonestos incompatíveis com a dignidade humana;

III - Injúria ou agressão ao Diretor professores ou funcionários, bem como autoridades constituídas;

IV - Filiação a organizações políticas que preguem doutrinas subversivas à ordem legal do País ou proselitismo dessas doutrinas, ainda que sem filiação;

V - Prática de delitos sujeitos à sanção penal. 


\section{CAPÍtULO V}

\section{Dos ingressos nos cursos}

\section{SEÇÃO I}

\section{Das Inscrições e dos Exames}

Artigo 31 - O ingresso na $1^{\text {a }}$ série dos Cursos Instrumentais e de Canto depende de aprovação em Exames de Admissão.

$\S 1^{\circ}$ - Os exames de que trata este artigo constarão de provas escritas e práticas de:

1 - Teoria e Solfejo (Percepção Musical) - eliminatória;

2 - Instrumento ou Canto.

$\S 2^{\circ}$ - Na elaboração das provas a que alude o parágrafo anterior, ter-se-á em vista os programas desenvolvidos no Curso Preparatório.

$\S 3^{\circ}$ - A inscrição nos Exames de Admissão far-se-á durante a primeira quinzena de dezembro, e o exame será realizado na primeira quinzena de janeiro.

$\S 4^{\circ}$ - O candidato a Exames de Admissão deve provar no ato da inscrição:

1 - Para os Cursos Instrumentais, que tem a idade mínima de 11 anos completos, ou a completar no decorrer do ano letivo a que corresponder o exame;

2 - Para o Curso de Canto, que tem a idade mínima de 15 anos completos para a mulher e 16 anos completos para o homem.

$\S 5^{\circ}$ - O candidato a Exame de Admissão deverá apresentar requerimento assinado por ele próprio, se maior de 18 anos, ou pelo pai ou responsável, se menor, instruído com os seguintes documentos:

1 - Certidão de nascimento;

2 - Prova de escolaridade;

3 - Programa de estudos, técnicos, escalas e peças devidamente preenchido em impresso fornecido pela Escola, observando-se o disposto no $\S 2^{\circ}$ deste artigo;

4 - Duas fotografias $3 / 4$

$\S 6^{\circ}$ - O requerimento, após aprovação do programa pelo C.T.A., será submetido a despacho do Diretor.

Artigo 32 - Os exames serão prestados perante Banca Examinadora constituída no mínimo por quatro professores do Conservatório.

Parágrafo único - Para os exames de Instrumento ou Canto, a Banca será composta de professores do mesmo naipe a que as provas se referirem.

Artigo 33 - Será considerado aprovado nos exames o candidato que obtiver nota mínima 6 (seis) em cada uma das provas realizadas. 
Parágrafo único - As notas serão de zero a dez, graduadas de meio em meio ponto.

Artigo 34 - Haverá Exame de Classificação nos Cursos Instrumentais e de Canto, para matrícula até o primeiro ano do Grau Geral.

$\S 1^{\circ}$ - Para matrícula no Grau Geral será exigido certificado de conclusão do curso ginasial ou equivalente.

$\S 2^{\circ}$ - O exame de que trata este artigo constará de provas eliminatórias, escritas e práticas, de classificação:

1 - Disciplinas complementares, observados os programas da seriação escolar correspondente ao instrumento ou Canto;

2 - Instrumento ou Canto.

$\S 3^{\circ}$ - Na elaboração das provas a que alude o parágrafo anterior, constará toda a matéria do programa de cada uma das disciplinas, inclusive do instrumento ou Canto.

$\S 4^{\circ}$ - Tanto a inscrição como os Exames de Classificação serão realizados nas datas previstas no $\S 3^{\circ}$ do artigo 31 .

$\S 5^{\circ}$ - O candidato a Exame de Classificação deverá apresentar requerimento assinado por ele próprio, se maior de 18 anos, ou pelo pai ou responsável, se menor, instruído com os seguinte documentos:

1 - Certidão de Nascimento;

2 - Prova de Escolaridade;

3 - Programa de estudos técnicos, escalas e peças devidamente preenchido em impresso fornecido pela Escola, observando-se o disposto nos parágrafos $2^{\circ}$ e $3^{\circ}$ deste artigo;

4 - Duas fotografias $3 / 4$.

$\S 6^{\circ}$ - O requerimento, após a aprovação do programa pelo C.T.A., será submetido a despacho do Diretor.

Artigo 35 - Os Exames de classificação serão prestados perante Banca Examinadora constituída no mínimo por quatro professores do Conservatório.

Parágrafo único - Para os exames de Instrumento ou Canto, que serão públicos, a Banca será composta de professores do mesmo naipe a que as provas se referirem.

Artigo 36 - Realizadas as provas de Instrumento ou Canto, a Banca classificará o candidato, através de notas, na série para a qual foi considerado apto.

Parágrafo único - As notas serão de zero a dez, graduadas de meio em meio ponto. 


\section{SEÇÃO II}

Da matrícula

Artigo 37 - A matrícula nos cursos mantidos pelo Conservatório será efetuada dentro da escala organizada pelo Diretor, encerrando-se o seu prazo cinco dias antes do início do ano letivo.

$\S 1^{\circ}$ - A matrícula será feita mediante requerimento do candidato ou seu representante legal, se menor, instruído com a seguinte documentação:

1 - Para o Curso de Iniciação Musical:

Certidão de nascimento;

Atestado de vacina e saúde;

Duas fotografias $3 \times 4$.

2 - Para o Curso Preparatório:

Certidão de nascimento ou casamento;

Atestado de vacina e saúde;

Prova de escolaridade;

Duas fotografias $3 \times 4$.

3 - Para a $1^{\mathrm{a}}$ série dos Cursos Instrumentais e de Canto:

Certificado de aprovação no exame de admissão;

Certidão de nascimento ou casamento;

Atestado de vacina e saúde;

Prova de escolaridade;

Duas fotografias $3 \times 4$;

4 - Para o Grau Geral dos Cursos Instrumentais e de Canto:

Certificado de conclusão do Grau Fundamental;

Certificado de conclusão de curso ginasial ou equivalente;

Duas fotografias $3 \times 4$.

5 - Para os Cursos de Aperfeiçoamento e Composição e Regência:

Diploma de conclusão de Curso Instrumental ou de Canto, expedido por Conservatório oficial;

Certificado de conclusão de curso colegial ou equivalente;

Certificado de aprovação em exame de suficiência prestado perante Banca deste Conservatório, para os alunos diplomados por estabelecimento particular;

Atestado de vacina e saúde; 
Duas fotografias $3 \times 4$.

$\S 2^{\circ}$ - Dos candidatos à matrícula, em qualquer dos cursos, maiores de 18 anos, exigir-se-á atestado de idoneidade moral firmado por dois servidores públicos estaduais, e, para fins de anotação, a apresentação do título de eleitor ou prova de quitação das obrigações eleitorais.

$\S 3^{\circ}$ - Dos candidatos do sexo masculino, maiores de 17 anos, exigir-se-á prova de quitação com as obrigações militares.

$\S 4^{\circ}$ - O exame de suficiência de que trata o item 5, letra “c", $\$ \mathbf{1}^{\mathbf{0}}$ deste artigo, constará de provas cujos programas serão elaborados pelos professores das respectivas disciplinas e aprovados pelo C.T.A.

Artigo 38 - A matrícula dos alunos promovidos às séries imediatas dos diversos cursos será feita mediante simples aposição da assinatura do aluno ou de seu representante legal, se menor, em livro próprio.

Artigo 39 - Ao aluno reprovado em uma só disciplina complementar, será permitida a matrícula sob dependência, em série seguinte, exceto na transição do Grau Fundamental para o Geral.

Artigo 40 - Será recusada a matrícula ao aluno reprovado por dois anos consecutivos.

Artigo 41 - Mediante requerimento devidamente justificado, poderá o aluno trancar sua matrícula por dois anos letivos.

Parágrafo único - Só poderá ser concedido novo trancamento de matrícula, após frequência normal às aulas durante um ano letivo.

Artigo 42 - Será cancelada a matrícula do aluno que, sem causa justificada, faltar a 4 aulas consecutivas de instrumento, ou 8 interpoladas, durante o ano letivo.

\section{SEÇÃO III}

\section{Da transferência}

Artigo 43 - A transferência de alunos de outros estabelecimentos só se efetuará no Grau Fundamental e na época das matrículas depois de aprovada pelo C.T.A., havendo vagas e mediante exame de classificação.

Parágrafo único - O candidato a transferência, deverá apresentar os seguintes documentos:

1 - Guia de transferência devidamente autenticada;

2 - Histórico da vida escolar; em que fique comprovada a equivalência dos programas de ensino. 
Artigo 44 - Aos funcionários públicos federais, estaduais, municipais, civis e militares, autárquicos ou de sociedade de economia mista, que forem removidos ou transferidos, será assegurada, bem como a seus dependentes legais, a matrícula em qualquer época do ano independentemente da existência de vaga, em cursos congêneres deste Conservatório, mediante exame de classificação.

Artigo 45 - A promoção dos alunos à série superior dependerá, em qualquer curso, da frequência e do aproveitamento revelado durante o ano letivo, nos termos do artigo 50.

Artigo 46 - A frequência às aulas de qualquer disciplina será obrigatória, não podendo ser admitido às provas finais o aluno que não tiver comparecido a pelo menos $85 \%$ da totalidade das aulas dadas durante o ano, em cada uma das disciplinas.

Artigo 47 - As aulas de reposição serão computadas para o cálculo do mínimo de frequência estabelecido.

Artigo 48 - O aluno deverá completar o minímo de horas de estágio a que estiver sujeito.

Parágrafo único - A forma e a duração do estágio serão estabelecidas pelo C.T.A., ouvido o professor.

Artigo 49 - Não haverá abono de faltas.

Artigo 50 - Considerar-se-á aprovado o aluno que obtiver Nota Final igual ou superior a 6 (seis) em cada disciplina.

$\S 1^{\circ}$ - O cálculo da Nota Final far-se-á levando-se em conta os seguintes elementos:

1 - Média aritmética das notas atribuidas nos meses de março, abril, maio, junho, agosto, setembro, outubro e novembro, considerando-se inabilitado para a prestação do Exame Final o aluno com média inferior a 6 (seis);

2 - Nota de Exame Final, que deverá ser igual ou superior a 6 (seis) para efeito de aprovação. $\S 2^{\circ}$ - As notas serão atribuídas na escala de zero a dez, graduadas de meio em meio ponto.

$\S 3^{\circ}$ - A Nota Final de cada disciplina será a média aritmética apurada entre os elementos constantes dos itens 1 e 2 do $\S 1^{\circ}$ deste artigo, elevando-se a primeira decimal para mais quando a segunda for igual ou superior a 5 (cinco).

Artigo 51 - O professor de cada disciplina atribuirá mensalmente, a cada aluno, nota correspondente ao aproveitamento apurado por meio de trabalhos realizados, execução de estudos e de peças, provas práticas, provas escritas e arguições, conforme a natureza da disciplina.

Parágrafo único - Se por falta de frequência do aluno, não se puder apurar o seu aproveitamento, ser-lhe-á atribuida nota zero. 
Artigo 52 - O Exame Final de que trata o $\S 1^{\circ}$ do artigo 50, abrangerá toda a matéria do programa de cada disciplina.

$\S 1^{\circ}$ - Não poderá sorteio de ponto.

$\S 2^{\circ}$ - As provas deverão ser objetivas, de forma a possibilitar que o aluno demonstre conhecer toda a matéria lecionada.

$\S 3^{\circ}$ - Nas provas de Instrumento e de Canto poderá o aluno executar livremente, dentro do programa aprovado, estudos, peças e escalas de sua escolha, cabendo à Banca Examinadora determinar outros trechos que queira ouvir.

$\S 4^{\circ}$ - É vedado aos membros da Banca interromper o aluno durante a prova, sob qualquer pretexto.

Artigo 53 - O Exame Final a que se refere o $\S 1^{\circ}$, item 2, do artigo 50, será realizado na primeira quinzena de janeiro, após o Conservatório ter completado 200 dias de aula, excluído deste cômputo o tempo reservado a provas e exames.

$\S 1^{\circ}$ - Não se realizará mais de uma prova ou exame por dia, para cada classe.

$\S 2^{\circ}$ - O horário dos exames, elaborado pela Secretaria, e a relação das matérias serão dados a conhecer aos alunos até o dia 20 de dezembro.

$\S 3^{\circ}$ - A duração das provas escritas será de 90 minutos, no mínimo e 120 minutos no máximo, contados da apresentação das questões aos examinandos.

$\S 4^{\circ}$ - A duração das provas práticas será condicionada à execução do programa escolhido pelo aluno e do determinado pela Banca Examinadora, observando o disposto no $\S 4^{\circ}$ do artigo 52.

$\S 5^{\circ}$ - O Exame Final versará sobre a matéria lecionada durante o ano letivo, ficando asseguradas aos professores, nos exames e provas, a liberdade de formulação de questões e a autoridade de julgamento, observadas as diretrizes metodológicas.

$\S 6^{\circ}$ - Terminados os exames finais, a Direção do Conservatório marcará prazo para vista das provas, que será dada em caráter obrigatório, com a presença do professor, do aluno e do seu responsável, se for o caso.

Artigo 54 - O Exame Final será realizado perante Banca Examinadora formada por professores do próprio estabelecimento.

$\S 1^{\circ}$ - A Banca Examinadora, para as disciplinas complementares, será formada pelo respectivo professor e mais dois membros.

$\S 2^{\circ}$ - Para Instrumento ou Canto, comporão a Banca Examinadora quatro professores no mínimo, sendo:

1 - Presidente; 
2 - Dois ou mais membros;

3 - O professor do aluno, que não dará nota.

$\S 3^{\circ}$ - Ao presidente compete zelar pela regularidade do respectivo trabalho, devendo ser comunicada ao Diretor qualquer irregularidade observada.

$\S 4^{\mathrm{o}}$ - O resultado do julgamento, dado por escrito e assinado pelos membros da Banca, na folha para esse fim destinado, será transcrito em livro próprio por funcionário da Secretaria devidamente autorizado.

$\S 5^{\circ}$ - A nota do exame será a média aritmética das notas dadas pelos examinadores.

$\S 6^{\circ}$ - Caberá ao Diretor promover a substituição do examinador no caso de falta, observando o disposto no parágrafo único do artigo 19 deste Regulamento.

Artigo 55 - O comparecimento do aluno ao exame será comprovado pela aposição de sua assinatura em folha própria, fornecida pela Banca Examinadora.

Parágrafo único - Ao aluno que se retirar depois de iniciado o exame, será atribuída nota zero.

\section{SEÇÃO V}

\section{Da segunda chamada}

Artigo 56 - Conceder-se-á segunda chamada de exames e de provas ao aluno que, tendo faltado à primeira, a requeira no prazo de oito dias contados da falta do exame ou prova, e comprove a falta por um destes motivos:

I - Doença;

II - Gala;

III - Nojo;

IV - Obrigações militares;

V - Doação de sangue;

VI - Motivos religiosos;

VII - Interrupção de transporte.

\section{SEÇÃO VI}

Da revisão de provas

Artigo 57 - Conceder-se-á recisão de provas de exames escritos.

$\S 1^{\circ}$ - O pedido de revisão, de que trata o presente artigo, poderá ser de iniciativa; 
1 - Do professor que julgou as provas desde que apresente por escrito, à Direção do Conservatório as suas razões;

2 - Do responsável pelo aluno, em requerimento fundamentado e dirigido à Direção do Conservatório;

3 - Do próprio aluno, se capaz.

$\S 2^{\circ}$ - A revisão de provas será requerida dentro do prazo máximo de oito dias, contados da data que foi concedida vista das mesmas aos interessados.

$\S 3^{\circ}$ - Uma vez deferida a petição, esta será, juntamente com a própria encaminhada ao professor que a julgou, o qual, feita a revisão, emitirá no próprio requerimento sua conclusões.

Artigo 58 - Do ato do professor caberá recurso ao C.T.A., se interposto dentro do prazo de cinco dias contados da data em que o recorrente tomou conhecimento da decisão.

Parágrafo único - O C.A.T., se for o caso, solicitará pronunciamento por escrito de professores do Conservatório, e emitirá decisão final, irrecorrível.

Artigo 59 - Não haverá revisão de provas de exames de admissão, classificação e suficiência.

\section{SEÇÃO VII}

\section{Do ano escolar e sua duração}

Artigo 60 - $\mathrm{O}$ ano escolar inicia-se no primeiro dia útil de fevereiro e termina no dia 20 de dezembro.

$\S 1^{\text {o }}$ - São períodos de férias escolares;

1 - De 16 a 31 de janeiro;

2 - O mês de julho;

3 - De 21 a 31 de dezembro.

$\S 2^{\circ}$ - Não haverá aulas durante as semanas de Carnaval, da Páscoa, da Pátria e da Música.

$\S 3^{\circ}$ - O período letivo inicia-se no dia 8 de fevereiro, encerrando-se a 20 de dezembro.

$\S 4^{\circ}$ - O período de $1^{\circ}$ a 7 de fevereiro será ocupado pelos professores para o planejamento escolar.

$\S 5^{\circ}$ - Serão obrigatoriamente comemoradas as grandes datas cívicas.

$\S 6^{\circ}$ - As comemorações a que alude o parágrafo anterior deverão ser realizadas nos respectivos dias, ainda que recaiam em domingo, procedendo-se obrigatoriamente à assinatura de presença dos elementos dos corpos docente e administrativo, bem como a verificação da frequência dos alunos. 
$\S 7^{\circ}$ - A duração do ano letivo será de 200 dias, excluídos deste cômputo os dias reservados para provas e exames.

\section{SEÇÃO VIII}

\section{Dos horários}

Artigo 61 - Os horários de aula, elaborados pela Secretaria antes do início do ano letivo, só poderão ser alterados se assim o exigir a conveniência do ensino, mediante aprovação do Diretor.

Artigo 62 - Toda vez que qualquer das disciplinas dos Cursos mantidos pelo Conservatório não completar os limites de aulas dadas, previstos neste Regulamento, o Diretor organizará horário de aulas de reposição, até atingir os referidos limites.

$\S 1^{\circ}$ - Considera-se como aula prevista a que o professor deva ministrar de conformidade com o horário, durante o ano escolar.

$\S 2^{\circ}$ - Entende-se por aula dada aquela que o professor efetivamente ministrar dentro do horário escolar estabelecido.

Artigo 63 - Sempre que se fizer necessária a reposição de dias letivos, os períodos de férias escolares poderão ser reduzidos.

Artigo 64 - As aulas de reposição serão ministradas, no segundo semestre, devendo os professores responsáveis elaborarem planos de trabalho que serão submetidos à aprovação do C.T.A.

Parágrafo único - Se ocorrer a necessidade de reposição de aulas por inexistência de professor da disciplina, ou afastamento prolongado do respectivo titular, a mesma far-se-á no primeiro semestre, observado o critério fixado neste artigo.

\section{SEÇÃO IX}

\section{Das atividades complementares}

Artigo 65 - Serão consideradas complementares as atividades educativas e artísticas que, aperfeiçoando os trabalhos regulares da disciplina, se realizarem fora do horário comum de aulas.

Artigo 66 - As atividades complementares de cada disciplina serão planejadas e propostas, no início do ano letivo, pelos respectivos professores e aprovadas pelo C.T.A. 
Artigo 67 - Cada professor responsável por atividades complementares fica obrigado, após sua realização, a apresentar ao Diretor relatório dos resultados.

Artigo 68 - As atividades complementares, dada a sua natureza, não deverão sobrecarregar os alunos a ponto de impedí-los de cumprir as suas obrigações normais.

Artigo 69 - Constituem atividades complementares obrigatórias:

I - Audições ou recitais de alunos, nesta ou em outras cidades;

II - Concertos ou apresentações realizados pela Orquestra, Coral, Banda e Fanfarra, realizados nesta ou em outras cidades;

III - Comparecimento aos concertos e recitais promovidos pelo Conservatório;

IV - Excursões pedagógicas para comparecimento a concertos ou recitais em outras cidades;

V - Participação em concursos, representando o Conservatório;

VI - Comparecimento aos ensaios dos conjuntos de que fizer parte.

Parágrafo único - Ao aluno que participar da atividade do inciso V deste artigo poderá suprir, com o repertório que trabalhou para o concurso, qualquer insuficiência do programa de exames de Instrumento ou Canto.

Artigo 70 - Para prestar exames, o aluno deverá cumprir um mínimo de atividades complementares determinado pelo C.T.A.

\section{SEÇÃO X}

\section{Dos Certificados e Diplomas}

Artigo 71 - Aos candidatos aprovados em exames de admissão, classificação e suficiência serão expedidos os respectivos Certificados, para efeito de matrícula.

Artigo 72 - Serão conferidos Certificados aos alunos aprovados nas séries finais dos Cursos:

I - Iniciação Musical;

II - Preparatório

III - Instrumentais e de Canto - Grau Fundamental;

IV - Aperfeiçoamento;

V - Seminários e cursos intensivos.

Artigo 73 - Aos alunos que concluirem os Cursos Instrumentais, de Canto, de Bailado e de Composição e Regência serão conferidos os respectivos Diplomas.

$\S 1^{\circ}$ - Os Diplomas a que se refere este artigo serão registrados em livro próprio do estabelecimento.

$\S 2^{\circ}$ - Os Diplomas e Certificados serão assinados pelo Diretor, pelo Secretário do Conservatório e pelo Diplomando. 
Artigo 74 - Não haverá expedição de segunda via de Diplomas podendo, a requerimento do interessado, ser-lhe expedida certidão de inteiro teor.

\section{CAPÍTULO VI \\ Dos Órgãos Escolares}

\section{SEÇÃO I}

\section{Do Grêmio Estudantil}

Artigo 75 - Os alunos do Conservatório poderão organizar grêmio recreativo, artístico ou cultural, sem cunho político, que funcionará sob assistência de professor designado pela Congregação e do Diretor.

Artigo 76 - Serão aprovados pela Congregação os estatutos do Grêmio, que devem consignar a sua subordinação à Direção do Conservatório e o voto secreto para as eleições.

\section{SEÇÃO II}

\section{Da Associação dos Ex-alunos}

Artigo 77 - A Associação de Ex-alunos, cuja constituição será facultativa, funcionará como orgão de promoção do Conservatório, observando os seus membros as seguintes diretrizes:

I - Acompanhar os destinos do Conservatório e manter os laços de união com a Escola e entre si;

II - Permutar, quando reunidos, suas experiências profissionais transmitindo-as ainda aos demais membros;

III - Manter-se a par das inovações introduzidas no Conservatório;

IV - Preocupar-se, sempre, em atualizar seus conhecimentos, através de cursos e seminários.

Artigo 78 - Para consecução das diretrizes contidas no artigo anterior a Associação realizará, no Conservatório, uma Assembléia Anual no dia 10 de dezembro data comemorativa da Declaração Universal dos Direitos do Homem.

Parágrafo único - Nesse mesmo dia, à noite, a Associação organizará uma apresentação artístico-cultural de seus membros.

Artigo 79 - O estatuto da Associação dos Ex-alunos será aprovado pela Congregação do Conservatório. 


\section{SEÇÃO III}

\section{Da Associação de Pais e Mestres}

Artigo 80 - A Associação de Pais e Mestres, cuja constituição será facultativa, funcionará como órgão complementar de natureza consultiva da Administração do Conservatório e será regida pelos seguintes órgãos:

I - Assembléia Geral, constituída de todos os pais de alunos e professores do Conservatório; II - Conselho Consultivo, constituído de igual número de pais e professores, até o máximo de vinte membros, todos eleitos em assembléia geral;

III - Diretoria, eleita pelo Conselho Consultivo, e que compreenderá os seguintes cargos:

Presidente;

Secretário;

Tesoureiro;

Dois Vogais;

Conselho Fiscal composto de três membros.

$\S 1^{\circ}$ - O Diretor do Conservatório será o Presidente nato da Assembléia Geral, do Conselho Consultivo e da Diretoria da Associação de Pais e Mestres.

$\S 2^{\circ}$ - O estatuto da Associação de Pais e Mestres será aprovado pela Congregação.

Artigo 81 - Caberá à Associação de Pais e Mestres:

I - Promover por todos os meios ao seu alcance, a integração escola-comunidade;

II - Auxiliar a Direção do estabelecimento na organização de campanhas cívicas, assistenciais culturais e outras em que se empenhe o Conservatório.

III - Colaborar com a escola na investigação das causas e na busca de soluções para os problemas de rendimento escolar e desajuste disciplinar dos alunos.

Artigo 82 - Caberá à Assembléia Geral da Associação de Pais e Mestres:

I - Eleger os membros do Conselho Consultivo;

II - Discutir e votar as contas do exercício anterior;

III - Reunir-se ordinariamente, pelo menos uma vez por ano, no mês de março, para providências contidas no artigo $81 \mathrm{e}$, extraordinariamente, quantas vezes se fizerem necessárias, a critério de seu Presidente ou a requerimento de metade mais um de seus membros.

IV - Fixar anualmente, tendo em conta a capacidade econômica das famílias, as contribuições voluntárias dos alunos.

Artigo 83 - Caberá ao Conselho Consultivo da Associação de Pais e Mestres:

I - Eleger a Diretoria da Entidade: 
II - Deliberar sobre assuntos a que se referem os artigos 80 e 81 deste Regulamento.

III - Reunir-se, ordinariamente, durante o ano letivo, uma vez cada bimestre, e tantas vezes quantas se fizerem necessárias, a critério de seu Presidente ou a pedido de $2 / 3$ de seus membros.

Parágrafo único - $\mathrm{O}$ mandato de conselheiro será de um ano, admitida a recondução por mais um período.

Artigo 84 - Caberá à Diretoria:

I - Apreciar as sugestões feitas pelo Conselho Consultivo e a Assembléia Geral;

II - Encerrar as contas de exercício em fevereiro de cada ano, submetendo-se ao Conselho Fiscal, cujo parecer será apreciado pela Assembléia Geral;

III - Manter Escriturados e à disposição de qualquer membro da Associação os livros da entidade;

IV - Depositar todos os valores recebidos no Banco do Estado de São Paulo ou na Caixa Econômica Estadual sendo os cheques assinados conjuntamente pelo Presidente e pelo Tesoureiro.

Parágrafo único - O mandato de diretor será anual, permitida a recondução por um período.

\section{CAPÍTULO VII}

\section{Da Administração do Conservatório}

\section{SEÇÃO I}

\section{Dos órgãos diretivos}

Artigo 85 - Constituem órgãos diretivos:

I - O Diretor

II - O Conselho Técnico Administrativo (C.T.A.)

III - A Congregação

Parágrafo único - O Diretor do Conservatório deverá ser educador qualificado e habilitado para o exercício da profissão de músico. 


\section{SEÇÃo II}

\section{Das funções do Diretor}

Artigo 86 - Ao Diretor compete, além de outras atribuições legais:

I - Superintender todos os serviços;

II - Convocar e presidir as reuniões da Congregação e do C.T.A.;

III - Executar e fazer executar as resoluções da Congregação e do C.T.A.;

IV - Fiscalizar o emprego das verbas;

V - Movimentar os saldos eventuais;

VI - Visar as folhas de pagamento do pessoal;

VII - Classificar e reclassificar funcionários nas diferentes seções;

VIII - Aplicar penalidades regulamentares;

IX - Encerrar o ponto do pessoal administrativo e dos professores;

$\mathbf{X}$ - Aprovar os horários organizados;

XI - Assinar diplomas e certificados;

XII - Zelar pelo rigoroso cumprimento deste Regulamento.

\section{SEÇÃO III}

\section{Do Conselho Técnico Administrativo}

Artigo 87 - O Conselho Técnico Administrativo (C.T.A.) será constituido por 4 professores em exercício, eleitos pela Congregação. O Diretor será seu Presidente.

Artigo 88 - Os membros do C.T.A. serão eleitos de dois em dois anos, podendo ser reconduzidos.

Parágrafo único - A eleição será feita por escrutínio secreto, com a presença de pelo menos 2/3 dos membros da Congregação.

Artigo 89 - As vagas verificadas em virtude de renúncia, afastamento temporário ou definitivo, ou destituição da função, serão preenchidas na forma do artigo anterior e seu parágrafo, para exercer o mandato pelo tempo restante do respectivo exercício.

Artigo 90 - O C.T.A. reunir-se-á em sessão ordinária uma vez por mês.§ $1^{\circ}$ - O Diretor do Conservatório no início de cada mandato do C.T.A., designará um professor efetivo para seu substituto legal, em caso de impedimento. 
$\S 2^{\circ}$ - O C.T.A. poderá reunir-se extraordinariamente quando convocado pelo Diretor, por seu substituto legal ou, ainda, mediante solicitação escrita de 3 de seus membros.

$\S 3^{\circ}$ - De todas as sessões do C.T.A. será lavrada a competente ata.

Artigo 91 - As deliberações do C.T.A. só serão tomadas com a presença de pelo menos 3 dos seus membros, além do Presidente, e são válidas somente quando aprovadas por maioria dos membros presentes.

Artigo 92 - O membro do Conselho que sem justa causa deixar de comparecer a duas sessões ordinárias consecutivas, será considerado resignatário e deverá ser substituido na forma do artigo 89 .

Artigo 93 - São atribuições do C.T.A.:

I - propor ao Diretor medidas de caráter técnico ou administrativo no Conservatório, julgadas convenientes;

II - Aprovar os programas organizados pelos professores;

III - Constituir comissões especiais de professores para o estudo dos assuntos que interessam ao Conservatório:

IV - emitir pareceres sobre assuntos de ordem didática que devam ser submetidos à Congregação;

V- tomar conhecimento de representações de natureza administrativa, didática e disciplinar;

VI - fiscalizar a fiel execução do regime escolar, especialmente no que respeita a observância de horários e programas, bem como a atividade dos professores e alunos.

VII - Opinar sobre matéria que envolva interesse do ensino ou do Conservatório.

VIII - Fixar o número máximo de alunos nas aulas coletivas, tendo em vista o melhor aproveitamento do ensino.

IX - Aprovar os programas para exames de admissão, classificação, suficiência e promoção.

$\mathbf{X}$ - Decidir sobre a aplicação da penalidade de exclusão prevista no inciso IV do artigo 28 deste Regulamento.

XI - Autorizar a instalação de cursos previstos e sugerir ou aprovar a criação de novos, assim como o desdobramento de disciplinas.

XII - Convocar as reuniões de professores previstas no inciso I do artigo 23 deste Regulamento. 


\section{SEÇÃO IV}

\section{Da Congregação}

Artigo 94 - A Congregação será constituída pelos professores em exercício e pelo Diretor, que será seu presidente.

Parágrafo único - No impedimento do Diretor caberá a este designar um dos membros do C.T.A., para substituí-lo.

Artigo 95 - São atribuições da Congregação:

I - Eleger 4 professores para constituir o C.T.A.;

II - Reunir-se ordinariamente duas vezes por ano, nas primeiras quinzenas de fevereiro e dezembro, para decisões sobre assuntos didáticos, assim como para estudo de assuntos relacionados com o ensino e atividades escolares, sugeridos ou propostos pelo C.T.A. e pelo Diretor.

Parágrafo único - A Congregação poderá reunir-se extraordinariamente, por convocação do Diretor ou seu substituto legal, ou por solicitação escrita da maioria de seus membros, para providências de caráter urgente.

Artigo 96 - A convocação de reuniões da Congregação, será feita por escrita pelo Diretor, com antecedência de 72 horas, pelo menos, e com declaração de seus fins.

$\S 1^{\circ}$ - As deliberações só poderão ser tomadas com a presença de $2 / 3$ de seus membros.

$\S 2^{\circ}-$ Se, trinta minutos após afixada, não houver comparecido número suficiente, o Diretor fará lavrar o termo indicando os nomes dos professores que deixaram de comparecer, e convocará nova reunião, que se realizará com a presença de metade e mais um dos seus membros.

$\S 3^{\circ}$ - A falta às reuniões acarretará desconto proporcional na remuneração, desde que não seja abonada nos termos do $\S 1^{\circ}$ do artigo 110 da Lei $10.261 / 68$.

Artigo 97 - As reuniões da Congregação serão presididas pelo Diretor, ou seu substituto legal, e secretariadas pelo Secretário do Conservatório, lavrando-se sempre, em livro próprio, atas consignando minuciosamente todas as ocorrências.

$\S 1^{\circ}$ - Aberta a sessão, será feita a leitura da ata anterior, que depois de aprovada e assinada, será encerrada pelo Presidente.

$\S 2^{\circ}$ - O Presidente exporá a Ordem do Dia e dará a palavra aos membros que a pedirem, para discutir cada assunto por sua vez. 
$\S 3^{\circ}$ - Quando o assunto em debate convier partes distintas, poderá qualquer dos membros requerer seja cada uma delas discutida e votada separadamente.

$\S 4^{\circ}$ - Se, por falta de tempo ou circunstâncias ocasionais, uma ou mais das questões suscitadas não puder ser decidida na mesma sessão, o assunto deverá ser discutido em nova reunião.

Artigo 98 - As deliberações que digam respeito a interesses particulares de qualquer dos membros só poderão ser tomadas por escrutínio secreto, podendo o interessado participar da discussão, sem ter direito a voto.

Artigo 99 - O membro que assistir à sessão não poderá deixar de votar exceto, na hipótese do artigo anterior, nem abandonar a sessão sem justo motivo, incorrendo em falta igual a que se consigna pelo não comparecimento sem causa justificada.

\section{SEÇÃO V}

\section{Dos Serviços Administrativos}

Artigo 100 - Os serviços administrativos compõem-se de:

I - Expediente e Arquivo ( $1^{\text {a }}$ Seção);

II - Finanças ( $2^{\text {a }}$ Seção);

III - Biblioteca, Museu e Fonoteca ( $3^{\text {a }}$ Seção);

IV - Almoxarifado e Portaria (4 $4^{\mathrm{a}}$ Seção);

Artigo 101 - A $1^{\text {a }}$ Seção - Expediente e Arquivo compete:

I - Preparar todo o expediente do Diretor, atestados e certidões, bem como documento e papéis de interesse geral do Conservatório;

II - Preparar toda a correspondência;

III - Receber, protocolar, autuar, fichar, distribuir e arquivar os papéis e fornecer informações relativas ao seu andamento;

IV - Proceder a buscas para fornecimento de certidões, quando requeridas e devidamente autorizadas;

V - Dar aos interessados, quando determinada pela autoridade competente, vista de processos, documentos e papéis;

VI - Providenciar todo o expediente relacionado com os atos e fatos da administração de pessoal do Conservatório, e manifestar-se sobre os assuntos concernentes, manter em dia os 
assentamentos de pessoal e elaborar os boletins de frequência e folhas de pagamento respectivas; e

VII - Desempenhar outras atribuições que forem determinadas pelo Diretor.

Artigo 102 - À $2^{\text {a }}$ Seção - Finanças compete:

I - Elaborar a proposta orçamentária;

II - Manter registros necessários à apuração de custos;

III - Controlar a execução orçamentária segundo as normas estabelecidas;

IV - Emitir e assinar empenhos e subempenhos;

$\mathbf{V}$ - Verificar se foram atendidas as exigências legais e regulamentares para que as despesas possam ser empenhadas;

VI - Elaborar as programações financeiras da Unidade de Despesas;

VII - Examinar os documentos comprobatórios da despesa e providenciar os respectivos pagamentos dentro dos prazos estabelecidos, segundo a programação financeira;

VIII - Proceder à tomada de contas de adiantamentos concedidos e de outras formas de entrega de recursos financeiros;

IX - Emitir e assinar cheques, ordens de pagamento e de transferência de fundos e outros tipos de documentos adotados para a realização de pagamentos;

$\mathbf{X}$ - Atender a requisições de recursos financeiros;

XI - Manter registros necessários a demonstração das disponibilidades e dos recursos financeiros utilizados; e

XII - Desempenhar outras atribuições que lhe forem determinadas pelo Diretor.

Artigo 103 - À $3^{\text {a }}$ Seção - Biblioteca, Museu e Fonoteca, incumbe:

I - Coligir, ordenar, classificar, guardar e conservar os documentos, elementos estatísticos e dados discriminativos referentes às atividades do Conservatório;

II - Adquirir, registrar classificar, guardar e conservar as obras de interesse para o serviço;

III - Facilitar consultas e atividades que se relacionem com o uso dos elementos culturais que estejam sob seus cuidados;

IV - Organizar e incentivar o desenvolvimento dos serviços técnicos e especializados (museu e fonoteca), de acordo com suas finalidades e dentro das possibilidades financeiras próprias; V - Organizar, quando possível e sempre que oportuno, exposição de objetos históricos, de pesquisa folclórica e científica;

VI - Desempenhar outras atribuições que lhe forem determinadas pelo Diretor.

Artigo 104 - Á $4^{\text {a }}$ Seção - Almoxarifado e Portaria, incumbe: 
I - Lavrar contratos e atos de aquisição de material, abrir concorrências e tomar todas as demais providências relativas à aquisição de material e execução de serviços, observadas as normas legais vigentes;

II - Declarar, nas contas apresentadas, o recebimento do material ou a execução dos serviços;

III - Fornecer à $2^{a}$ Seção - Finanças - na parte referente ao material de serviço, os elementos necessários à confecção do orçamento programa;

IV - Registrar e controlar o material permanente e de consumo, promovendo sua distribuição, mediante a competente nota requisitória;

V - Organizar o mapa do movimento mensal de entrada e saída com a discriminação de custo, procedência, destino e saldo existente;

VI - Atender ao público, dando-lhes as informações da sua alçada;

VII - Providenciar a limpeza das dependências e zelar pela segurança e conservação dos seus bens e instalações;

VIII - Fazer entregas em geral;

IX - Expedir e entregar toda a correspondência;

$\mathbf{X}$ - Cumprir as demais atribuições que lhe forem cometidas pelo Diretor.

Parágrafo único - A encarregatura dos serviços de portaria, limpeza e conservação é inerente ao cargo de Zelador.

\section{SEÇÃO VI}

\section{Da Secretaria}

Artigo 105 - A Secretaria é orgão administrativo encarregado da execução de todos os trabalhos pertinentes à escrituração escolar.

Artigo 106 - Ao Secretário incumbe:

I - Organizar, superintender e realizar os serviços de escrituração escolar;

II - Redigir, subscrever e divulgar, por ordem do Diretor, instruções e editais relativos à vida escolar;

III - Atender aos elementos dos corpos docente e discente, prestando-lhes informações e esclarecimentos referentes à escrituração e legislação escolar;

IV - Subscrever, juntamente com o Diretor, atestados, certidões, diplomas, certificados, fichas escolares e sempre que couber, outros papéis de sua alçada;

V - Organizar os horários de aulas e alunos, submetendo-se à aprovação do Diretor;

VI - Organizar turmas para aulas coletivas e individuais e para exames;

VII - Expedir as carteiras de identidade escolar; 
VIII - Secretariar as reuniões do CTA e da Congregação, lavrando e subscrevendo os respectivos atos;

IX - Manter em dia o fichário e o arquivo de correspondência e documentário do CTA e da Congregação;

$\mathbf{X}$ - Desempenhar outras atribuições que lhe forem determinadas pelo Diretor.

Artigo 107 - Além de outros que o Diretor julgar necessário, a Secretaria terá livros de:

I - Atas das reuniões da Congregação;

II - Atas das reuniões do CTA;

III - Atas da Associação de Pais e Mestres;

IV - Ponto do pessoal docente;

V - Registro de inscrição em exames;

VI - Registro de matrículas ( um livro para cada curso );

VII - Carga e descarga de provas escritas;

VIII - Atas de resultados finais ( um livro para cada curso );

IX - Registro de Diplomas.

Parágrafo único - As atas de exames, o registro de notas mensais e o registro de notas de exames de todos os cursos serão consignados em folhas avulsas, encadernadas anualmente.

Artigo 108 - Nenhum documento da vida escolar poderá ser retirado do arquivo da Secretaria.

Parágrafo único - Poderão ser substituidos por cópias fotostáticas, devidamente autenticadas e legalizadas, quaisquer documentos do prontuário de alunos e ex-alunos, mediante autorização do Diretor, em requerimento do interessado.

\section{SEÇÃO VII}

\section{Do Horário e do Ponto}

Artigo 109 - O horário das aulas e dos serviços administrativos será determinado de acordo com as necessidades do ensino.

Artigo 110 - A tomada do Ponto pessoal administrativo será feita em livro próprio, na Portaria, enquanto não puder ser cumprido o disposto no $\S 1^{\circ}$ do artigo 120 da Lei n. 10.26168.

Artigo 111 - O professor terá livro de Ponto junto à Secretaria. 


\section{CAPÍTULO VIII}

\section{Das Disposições Finais}

Artigo 112 - Deverá ser dada especial atenção à Leitura à Primeira Vista e Transporte, Improvisação e Prática de Acompanhamento, que constituem matérias integrantes dos programas dos diversos cursos instrumentais e de Canto.

Artigo 113 - Aos alunos do Curso de Piano será facultado optar pelo estudo de qualquer outro instrumento em substituição à disciplina de Prática de Orquestra no Grau Fundamental.

Artigo 114 - Serão promovidas audições de alunos, com o fim de familiarizá-los com o público e servir de estímulo e vocações artísticas.

Artigo 115 - Subordinadas às possibilidades orçamentárias da Unidade de Despesa, e de acordo com a conveniência do ensino, serão realizadas audições, concertos e recitais, tanto de professores do Conservatório como de artistas de projeção, estranhos ao estabelecimento.

$\S 1^{\circ}$ - Nos termos deste artigo, poderão ser realizadas conferências, seminários e cursos intensivos ou de férias.

$\S 2^{\circ}$ - A programação das atividades previstas neste artigo será planejada no início de cada ano.

Artigo 116 - Com os recursos anualmente consignados em seu orçamento, serão organizados, mantidos e desenvolvidos pelo Conservatório:

I - Biblioteca de composições musicais e livros sobre música, arte dramática e assuntos relacionados com as atividades artísticas em geral;

II - Museu de instrumentos musicais que ofereçam interesse para o estudo de História da Música e do Folclore Nacional.

III - Laboratório de cenotécnica;

IV - Laboratório de gravações e filmagens destinado a propiciar, às diversas disciplinas, material audio-visual para fins pedagógicos e culturais;

V - Discoteca para ilustração musical, sendo a aquisição dos discos técnicamente orientada pelos professores, de acordo com as necessidades do ensino;

VI - Orquestra para estudo das disciplinas;

Prática de Orquestra;

Regência;

VII - Coral para estudo das disciplinas:

Canto Coral;

Regência. 
VIII - Banda Musical para prática de:

Instrumentistas;

Regência.

IX - Banda Musical (fanfarra);

$\mathbf{X}$ - Jornal Escolar;

XI - Concursos Musicais.

$\S 1^{\circ}$ - Serão integrantes da Orquestra, do Coral, da Banda e Fanfarra, segundo a especialidade, respectivamente, os alunos dos cursos instrumentais e de Canto e os professores destes cursos. $\S 2^{\circ}$ - Para efeito do parágrafo anterior poderá ser admitida a colaboração de músicos e cantores estranhos ao estabelecimento, à juízo do Diretor e mediante contrato.

$\S 3^{\circ}$ - Os alunos integrantes da Orquestra, do Coral e da Banda são obrigados à frequência nos ensaios e concertos, podendo receber, eventualmente, auxílio pecuniário para ressarcimento de despesas.

Artigo 117 - Poderão ser instalados no Conservatório, havendo recursos disponíveis, os setores de Artes Plásticas, Literatura, Teatro e Cinema, que funcionarão de acordo com estrutura e planejamento elaborados por especialistas.

Artigo 118 - Fica instituído junto à Seção de Biblioteca, Museu e Fonoteca do Conservatório o "Forum Narciso Pieroni", que se regerá por regulamento próprio, baixado por Portaria do Diretor.

Parágrafo único - A função de Secretária Executiva do "Forum", será exercida, sem onus para o Estado, pelo Chefe da Seção de Biblioteca, Museu e Fonoteca.

Artigo 119 - Poderão ser concedidas bolsas de estudo a alunos talentosos carentes de recursos, observadas as normas legais atinentes ao assunto e respeitadas as dotações orçamentárias próprias da Unidade de Despesa.

Parágrafo único - Uma Banca integrada por quatro professores do Conservatório, designada pelo Diretor, examinará os candidatos às bolsas de estudo.

Artigo 120 - Os alunos que concluírem o Grau Geral em qualquer curso receberão seus diplomas em cerimônia solene, cuja data será fixada pelo Diretor.

Artigo 121 - Para efeito do disposto no artigo 48 da Lei Federal 4.024/61, os Diplomas expedidos pelo Conservatório serão encaminhados pela Secretaria do estabelecimento, para registro no Ministério da Educação e Cultura.

Artigo 122 - O Conservatório promoverá, obrigatoriamente, de 15 a 22 de novembro de cada ano, a Semana da Música. 
Parágrafo único - Durante a Semana da Música não haverá aulas, porém os alunos e os professores ficarão à disposição do Conservatório, para participar das atividades programadas. Artigo 123 - Os casos omissos serão resolvidos pelo C.T.A.

\section{CAPÍTULO IX}

\section{Das Disposições Transitórias}

Artigo $1^{\circ}$ - Os alunos matriculados na vigência do Regulamento anterior, fica assegurada a conclusão do Curso que esteja frequentando no antigo regime.

Parágrafo único - Poderão os alunos referidos neste artigo adaptar suas matrículas ao novo Regulamento, desde que o requeiram ao Diretor e satisfaçam as novas normas nele estabelecidas.

Artigo $\mathbf{2}^{\mathbf{0}}$ - Ficam mantidas as decisões de caráter técnico e administrativo, referente ao ensino, adotadas em reuniões do C.T.A. e da Congregação, constantes das respectivas atas.

\section{PUBLICADO NO DIÁRIO OFICIAL DE}

O6 DE MARÇO DE 1971 


\section{ANEXO D - Homenagem ao Sr. Governador}

Ao estamparmos o seu retrato, nesta edição extraordinária, nós queremos, os da imprensa de Tatuí, em nome da população tatuiana, prestar uma sincera homenagem ao governador Lucas Nogueira Garcez, amigo desta terra. S. Excia. Houve por bem dotar a cidade natal de Paulo Setúbal com um estabelecimento de ensino superior, o primeiro do Estado, o que veio nos lisonjear sobremaneira, honrado-nos, assim, com uma escola que para nós representava algo como um sonho de difícil realização prática. Mas o sonho maravilhoso se concretizou com a promulgação da lei magnífica, que tomou o número 997.

Exortamos, aqui, mais uma vez, o povo tatuiano para que cerre fileiras em torno do seu grande Governador, em prestando-lhe todo o apoio moral, animando a prosseguir em sua obra de gigante na direção do nosso Estado, o líder da Federação brasileira.

Ao insigne Dr. Lucas Nogueira Garcez as nossas homenagens, o nosso preito de eterna gratidão.

\section{Um sonho que se realizou}

A segunda-feira desta semana marcou uma data histórica para Tatuí. O telefone nos trouxe, cerca das 14 horas, uma notícia das mais alvissareiras para a nossa gente: o Exmo. Sr. Governador do Estado sancionara a lei criando o Conservatório Dramático e Musical - o primeiro, oficial, em todo Estado.

O povo tatuiano, surpreendido pelo auspicioso fato, vibrou de entusiasmo e contentamento. A' chegada do noturno, a estação da Sorocabana encheu-se de gente para receber o seu dinâmico Prefeito, Dr. Aniz Boneder, prestando-lhe espontânea e significativa homenagem. Espoucaram fogos, a cidade foi sacudida por uma grande vibração, apesar da hora algo adiantada. Aglomerações se formaram, discutindo o assunto que a todos empolgava.

Em nosso número de domingo tivemos ocasião de ventilar o assunto. Nossos filhos poderão contar com mais um estabelecimento de ensino, onde as vocações para o teatro e a música o ambiente propício para o seu desenvolvimento e posterior consagração artística. Vejamos rapidamente o programa de ensino: teoria e solfejo, harmonia, história da música, pedagogia musical, folclore nacional, ensino de piano, violino, violoncelo, canto, orfeão, declamação lírica e dicção de arte dramática, etc. O campo é amplo e fecundo. Nossa mocidade poderá escolher à vontade a disciplina do seu gosto ou que mais esteja de acordo 
com os seus pendores artísticos. Tudo isso é maravilhoso! Algo tão grandioso que exorbitava de nossas ambições e possibilidade, no momento. Estamos realmente encantados com o régio presente. Parece um sonho de mil e uma noites, qualquer coisa que superou a nossa imaginação, um fato inusitado de largas repercussões no seio da cidade tatuiana, do seu povo honesto e trabalhador que, até aqui, sempre viu com ceticismo as promessas governamentais.

Como complemento, temos ainda grata notícia a dar ao povo: o velho e suntuoso edifício do Teatrão, como carinhosamente o chamamos, vai finalmente ser aproveitado com dignamente. Estão entabuladas negociações para que o mesmo seja doado ao Estado, a fim de ser aproveitado para o Conservatório Dramático e Musical de Tatuí. Eis outro fato que nos enche de júbilo. Causava pena ver aquele imóvel tão rico em arquitetura relegado ao abandono, servindo de depósito, humilhado como velhacouto de indigentes e párias da sociedade. Os nossos visitantes não escondem o seu desapontamento quando interrogam sobre a marcha das obras daquele magnífico edifício. E que respondemos nós? Ficamos constrangidos envergonhados. Essa é a verdade.

\section{Declarações do prefeito Aniz Boneder sobre a criação do conservatório dramático e musical.}

Aproveitando uma ligeira pausa nas manifestações de júbilo com que a população local, na noite memorável de 16 do corrente, à chegada de S. Paulo do Prefeito Aniz Boneder, festejou a criação do Conservatório Dramático e Musical de Tatuí - a reportagem do "Progresso" conseguiu atrair o dinâmico chefe do Executivo tatuiano até a redação, para uma entrevista sobre o magno acontecimento.

Naturalmente eufórico, contente, feliz pela vitória desta que há muito fez sua pelos liames indestrutíveis do coração o Dr. Aniz Boneder ditou ao repórter as seguintes palavras:

"A promulgação, na data de hoje, da lei 997, que cria o Conservatório Dramático e Musical em nossa cidade, representa uma conquista tão importante para o nosso progresso material e cultural, que torna desnecessária qualquer explanação com o intuito de encarecer o seu real valor. Esta manifestação ruidosa que agora mesmo sacode a nossa Praça da Matriz tomada de assalto pelo entusiasmo do povo de Tatuí, que dá largas ao seu júbilo pela obtenção do já seu Conservatório, diz bem do alto grau de compreensão de cada um no que isto representa para a vida do nosso município". 


\section{A luta foi árdua}

"Entretanto - prossegue o nosso entrevistado -, é preciso não esquecer que bem árduos foram os trabalhos para se atingir tão almejado fim. Quero, pois, em primeiro lugar, externar publicamente o reconhecimento e a gratidão do povo de Tatuí ao Exmo. sr. dr. Lucas Nogueira Garcez, digníssimo Governador do Estado, que houve por bem conceder à nossa cidade tão preciosa dádiva. Nossa gratidão é aqui igualmente hipotecada a esse amigo sincero, batalhador tenaz e incansável, grande e hábil parlamentar - o deputado Narciso Pierone, autor do projeto e artífice máximo do trabalho de o conduzir na Assembléia Legislativa do Estado".

\section{Artigos vetados}

O projeto de lei sofreu veto na parte referente ao quadro de funcionários e abertura de credito para instalação do Conservatório. A respeito, esclareceu o Dr. Aniz Boneder.

"Desejo frizar, para conhecimento de todos que os artigos em número de três, vetados pelo senhor Governador, e foram apenas por uma questão de ordem legal. Tanto assim, que S. Excia. no mesmo dia que remeter à Assembléia a mensagem sobre a parte vetada, encaminhará também nova mensagem criando os cargos e fixando o "quantum" necessário para ocorrer às despesas do Conservatório".

\section{Em junho ou janeiro a instalação}

A uma pergunta do repórter sobre a data do funcionamento da primeira escola de ensino superior de Tatuí, informou o Prefeito:

"É desejo do senhor Governador que a instalação e inicio das aulas se verifiquem a partir de janeiro de 1952. Todavia, é nossa intenção solicitar ao Exmo. Sr. Dr. Lucas Nogueira Garcez, por ocasião da visita de agradecimentos que lhe fará, dentro de dias, uma caravana de pessoas representativas deste município, a autorização para funcionamento imediato do Conservatório, as expensas da Prefeitura. Assim, caso o permita iniciaremos os trabalhos em princípio de junho, mesmo porque teremos que aguardar ainda a regulamentação do novo estabelecimento de ensino. Caso contrario, a instalação se verificará em princípios de janeiro no próximo ano." 